GA-A16584

\title{
ISOTEC FINAL REPORT
}

\section{MASTER}

by

N. B. ELSNER, J. CHIN, G. H. REYNOLDS,

J. H. NORMAN, J. C. BASS, and H. G. STALEY

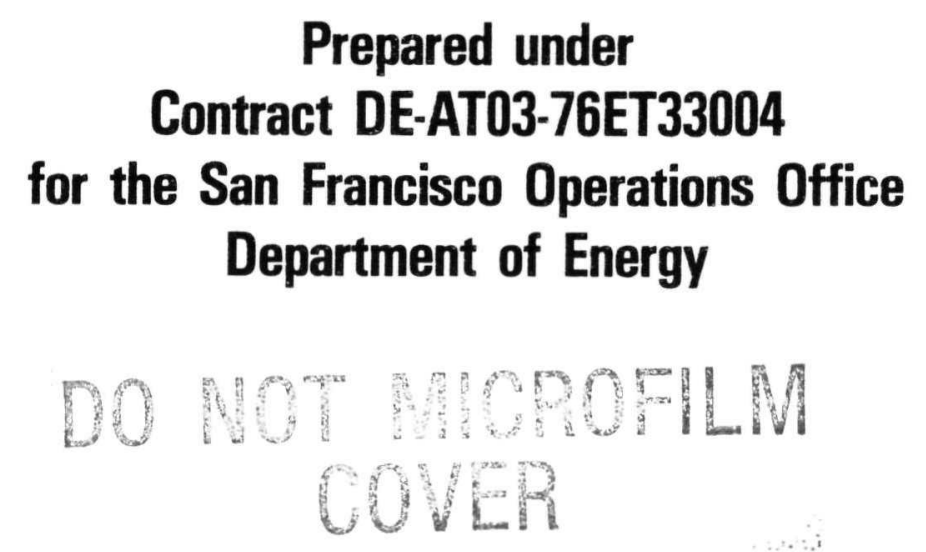

DATE PUBLISHED: NOVEMBER 1981 


\section{DISCLAIMER}

This report was prepared as an account of work sponsored by an agency of the United States Government. Neither the United States Government nor any agency Thereof, nor any of their employees, makes any warranty, express or implied, or assumes any legal liability or responsibility for the accuracy, completeness, or usefulness of any information, apparatus, product, or process disclosed, or represents that its use would not infringe privately owned rights. Reference herein to any specific commercial product, process, or service by trade name, trademark, manufacturer, or otherwise does not necessarily constitute or imply its endorsement, recommendation, or favoring by the United States Government or any agency thereof. The views and opinions of authors expressed herein do not necessarily state or reflect those of the United States Government or any agency thereof. 


\section{DISCLAIMER}

Portions of this document may be illegible in electronic image products. Images are produced from the best available original document. 
This report was prepared as an account of work sponsored by an agency of the United States Government. Neither the United States Government nor any agency thereof, nor any of their employees, makes any warranty, express or implied, or assumes any legal liability or responsibility for the accuracy, completeness, or usefulness of any information, apparatus, product, or process disclosed, or represents that its use would not infringe privately owned rights. Reference herein to any specific commercial product, process, or service by trade name, trademark, manufacturer, or otherwise, does not necessarily constitute or imply its endorsement, recommendation, or favoring by the United States Government or any agency thereof. The views and opinions of authors expressed herein do not necessarily state or reflect those of the United States Government or any agency thereof. 
GA-A16584

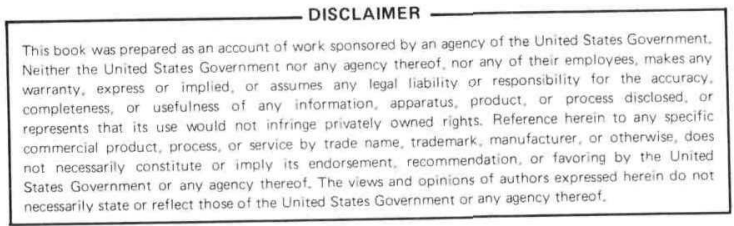

ISOTEC FINAL REPORT

by

N. B. ELSNER, J. CHIN, G. H. REYNOLDS,

J. H. NORMAN, J. C. BASS, and H. G. STALEY

Prepared under

Contract DE-AT03-76ET33004

for the San Francisco Operations Office

Department of Energy

GENERAL ATOMIC PROJECT 3246 DATE PUBLISHED: NOVEMBER 1981 
Blank Page 


\begin{abstract}
General Atomic (GA) developed processes to prepare $\mathrm{NdSe}_{1.5-\mathrm{x}}$. The partial pressure of $\mathrm{Se}_{2}$ above the $\mathrm{NdSe}_{1.5-x}$ was found to be a function of $\mathrm{x}$. The thermoelectric properties and the friability of the hot pressed element were also a function of $\mathrm{x}$. Process modification changed the value of $\mathrm{x}$, providing a method to control the properties of $\mathrm{N}$-type $\mathrm{NdSe}_{1.5-x}$ elements. A method of joining $\mathrm{NdSe}_{1.5-\mathrm{x}}$ to a nickel hot cap was developed using a gold foil intermediate. $\mathrm{NdSe}_{1.5-\mathrm{x}}$ was diffusion-bonded to $\mathrm{PbTe}$ by the same process developed for $\mathrm{Gd}_{2} \mathrm{Se}_{3}$. Couples were fabricated from $(\mathrm{Cu}, \mathrm{Ag})_{2} \mathrm{Se} / \mathrm{Fe} /(\mathrm{Bi}, \mathrm{Sb})_{2} \mathrm{Te}_{3}$ and $\mathrm{NdSe}_{1.5-x} \mathrm{PbTe}$ elements. Limited couple test data were obtained.

General Atomic examined methods to develop high-efficiency couples made from segmented elements containing $(\mathrm{Cu}, \mathrm{Ag})_{2} \mathrm{Se} \mathrm{P}$-type material and $\mathrm{NdSe}_{1.5-x} \mathrm{~N}$-type material. Techniques were developed to reproducibly prepare and hot press $(\mathrm{Cu}, \mathrm{Ag})_{2} \mathrm{Se}$ segments and elements with a metallurgically joined MoRe hot cap. This hot cap and a $\mathrm{W}-26 / \mathrm{Re}$ wire mesh used to make the hot cap junction were found to be stable in contact with $(\mathrm{Cu}, \mathrm{Ag})_{2} \mathrm{Se}$ at $750^{\circ} \mathrm{C}$. Stability of $(\mathrm{Cu}, \mathrm{Ag})_{2} \mathrm{Se}$ to current flow in a thermal gradient was examined. This report describes specifications for vapor suppression to improve the stability of $\mathrm{P}$-type $(\mathrm{Cu}, \mathrm{Ag})_{2} \mathrm{Se}$ in thermal gradient life tests and presents life test information on match-loaded $(\mathrm{Cu}, \mathrm{Ag})_{2} \mathrm{Se}$ and $(\mathrm{Cu}, \mathrm{Ag})_{2} \mathrm{Se} / \mathrm{Fe} /(\mathrm{Bi}, \mathrm{Sb})_{2} \mathrm{Te}_{3}$ elements.
\end{abstract}


Blank Page 


\section{CONTENTS}

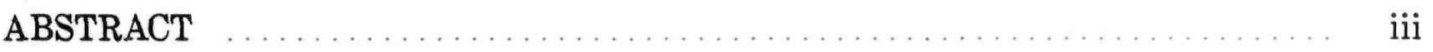

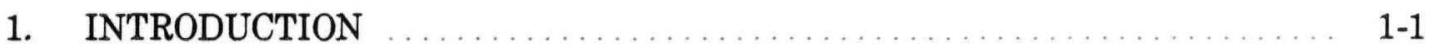

2. SEGMENTED P-TYPE ELEMENT STUDIES . . . . . . . . . . . . 2-1

2.1. Fabrication Development of Segmented P-Type Elements ....... 2-1

2.1.1. Hot Pressing Modification ..................... 2-1

2.1.2. Mo-Re Hot Caps ............................. 2-4

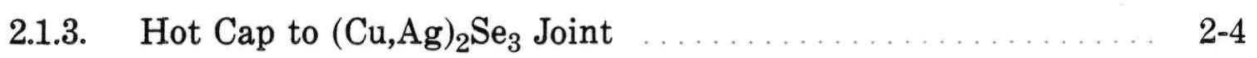

2.1.4. Vapor Suppression .......................... 2-12

2.2. Evaluation of Segmented P-Type Elements ............... 2-20

2.2.1. Isothermal Testing . . . . . . . . . . . . . . . . . $2-20$

2.2.2. Zero-Current Thermal Gradient Testing .............. 2-20

2.2.3. $\quad$ Life Testing of P Element with Current . . . . . . . . . . . 2-38

3. SEGMENTED N-ELEMENT DEVELOPMENT $\ldots \ldots \ldots \ldots \ldots \ldots \ldots \ldots \ldots . . . \ldots \ldots \ldots$

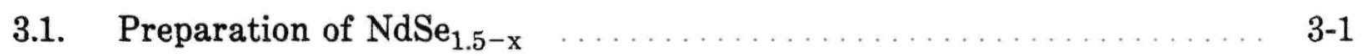

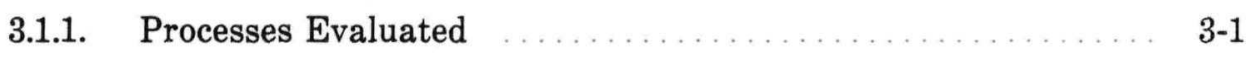

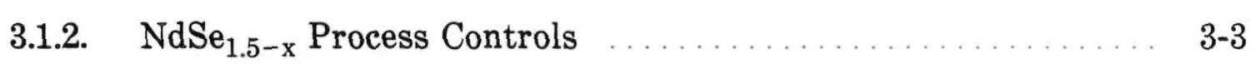

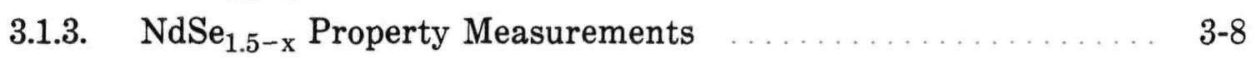

3.2. $\quad \mathrm{NdSe}_{1.5-\mathrm{x}}$ Element Fabrication Studies ................... 3-15

3.2.1. Hot Pressing $\mathrm{NdSe}_{1.5-\mathrm{x}}$ Made by Method $1 \mathrm{GA}$ or Ames Laboratory Processes from Controlled Ratios of Neodymium and Selenium Starting Materials

3.2.2. Hot Pressing $\mathrm{NdSe}_{1.5-\mathrm{x}}$ Made by Method 2 from the

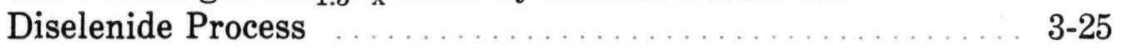

3.2.3. $\quad \mathrm{NdSe}_{1.5-\mathrm{x}}$ Hot Pressing Summary . . . . . . . . . . . . . . . 3-28

3.3. N-Element Hot Cap Joining Studies . . . . . . . . . . . . . . . . . . 3-39

3.2.4. Preparation of Segmented N Elements ............... $3-48$

Reference . . . . . . . . . . . . . $3-48$

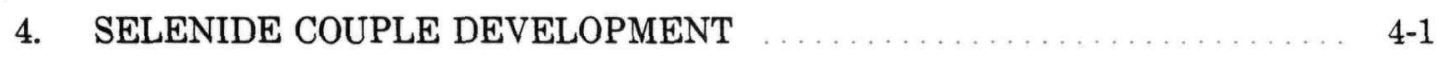

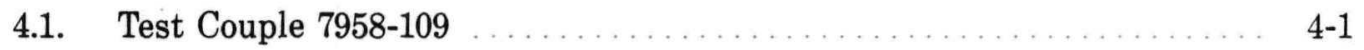

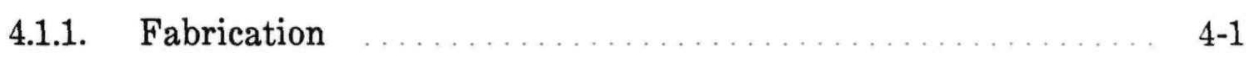

4.1.2. Couple 7958-109 Thermal Gradient Testing ............. 4-1

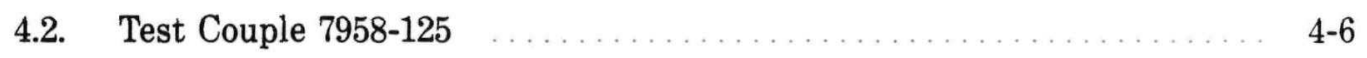

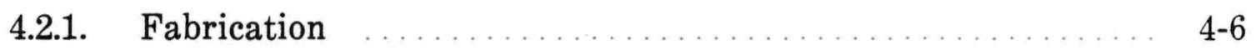

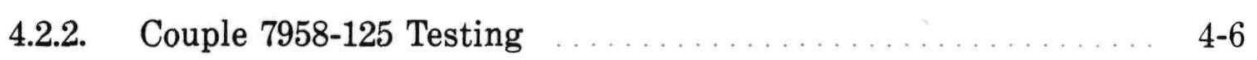

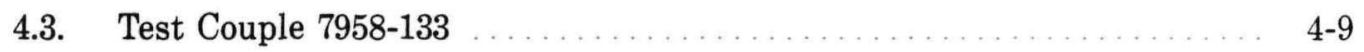

5. SUMMARY - ISOTEC TECHNOLOGY PROGRAM … . $\ldots \ldots \ldots \ldots \ldots \ldots \ldots \ldots \ldots \ldots$

APPENDIX A: A PHENOMENOLOGICAL EQUATION TRANSPORT MODEL OF THE STABILITY OF P-TYPE $(\mathrm{Cu}, \mathrm{Ag})_{2} \mathrm{Se}$ AS A THERMOELECTRIC MATERIAL 


\section{FIGURES}

2-1. Segmented $\mathrm{P}$ element $(\mathrm{Cu}, \mathrm{Ag})_{2} \mathrm{Se} /(\mathrm{Bi}, \mathrm{Sb})_{2} \mathrm{Te}_{3}$

2-2. Fabrication sequence for the preparation of $(\mathrm{Cu}, \mathrm{Ag})_{2} \mathrm{Se} /(\mathrm{Bi}, \mathrm{Sb})_{2} \mathrm{Te}_{3}$ segmented elements

2-3. Scanning electron photomicrograph of the ion-plated rhenium coating, run $8029-65$, on 316 stainless steel

2-4. Nickel hot cap/tungsten foil/( $\mathrm{Cu}, \mathrm{Ag})_{2} \mathrm{Se}$ after $172 \mathrm{~h}$ at $750^{\circ} \mathrm{C}$

2-5. Macro view of a $(\mathrm{Cu}, \mathrm{Ag})_{2} \mathrm{Se} /(\mathrm{Bi}, \mathrm{Sb})_{2} \mathrm{Te}_{3}$ segmented element with a Mo-47/Re hot cap

2-6. Diffusion-bonded W-26/Re mesh in a Mo-50/Re cap as fabricated

2-7. Diffusion-bonded W-26/Re mesh in a Mo-50/Re cap with wire ends folded inward ready for element hot pressing

2-8. Hot cap to $(\mathrm{Cu}, \mathrm{Ag})_{2} \mathrm{Se}$ joint configurations

2-9. Pushing the bottom die off the element

2-10. Pressing element out of upper die

2-11. Schematic diagram of a segmented $(\mathrm{Cu}, \mathrm{Ag})_{2} \mathrm{Se} /(\mathrm{Bi}, \mathrm{Sb})_{2} \mathrm{Te}_{3}$ element showing the vapor suppression sleeve, coating, and insulation with their effective baffling factors

2-12. Schematic diagram of a segmented $\mathrm{P}$ element with the W-26/Re wire mesh tack-welded to the center of a one-piece Mo-Re hot cap

2-13. Schematic diagram of a segmented $P$ element with the W-26/Re wire mesh tack-welded to the edge of a one-piece Mo-Re hot cap

2-14. Schematic diagram of a segmented $P$ element with W-26/Re wire mesh tack-welded to the edge of a two-piece rhenium hot cap

2-15. Microprobe scan of double segmented $P$ element specimen 6875-102-1 after a $400-\mathrm{h}, 475^{\circ} \mathrm{C}$ isothermal heat treatment

2-16. Macrophoto of doubly segmented P-type element 6875-132-12 after $64 \mathrm{~h}$ in a $\mathrm{T}_{\mathrm{H}}=755^{\circ} \mathrm{C}, \mathrm{T}_{\mathrm{C}}=133^{\circ} \mathrm{C}$ zero-current thermal gradient test

2-17. Seebeck coefficients of segmented P-type element 6875-132-35 during zero-current thermal gradient compatability testing

2-18. Resistivity values of segmented P-type element 6875-132-35 during zero-current thermal gradient compatibility testing

2-19. Seebeck coefficients of P-type element 6875-132-35 containing $\left.(\mathrm{Cu}, \mathrm{Ag})_{2} \mathrm{Se} / \mathrm{Fe} / \mathrm{Bi}, \mathrm{Sb}\right)_{2} \mathrm{Te}_{3}$ segments sequentially hot-pressed zero-current, $754^{\circ} \mathrm{C} / 107^{\circ} \mathrm{C}$, thermal gradient testing

2-20. Resistivity values of P-type element 6875-132-35 containing $(\mathrm{Cu}, \mathrm{Ag})_{2} \mathrm{Se} / \mathrm{Fe} /(\mathrm{Bi}, \mathrm{Sb})_{2} \mathrm{Te}_{3}$ segments sequentially hot-pressed zero-current, $754^{\circ} \mathrm{C} / 107^{\circ} \mathrm{C}$, thermal gradient testing

2-21. Microprobe examination of doubly segmented $\mathrm{P}$ element $6875-132-35$ after $2490 \mathrm{~h}$ in a $754^{\circ} \mathrm{C} / 107^{\circ} \mathrm{C}$, thermal gradient

2-22. Seebeck coefficients of P-type element 6875-141 containing $(\mathrm{Cu}, \mathrm{Ag})_{2} \mathrm{Se} / \mathrm{Fe} /(\mathrm{Bi}, \mathrm{Sb})_{2} \mathrm{Te}_{3}$ segments sequentially hot pressed in separate dies during zero-current, $752^{\circ} \mathrm{C} / 190^{\circ} \mathrm{C} / 47^{\circ} \mathrm{C}$, thermal gradient testing 
2-23. Resistivity values of P-type element 6875-141 containing $(\mathrm{Cu}, \mathrm{Ag})_{2} \mathrm{Se} / \mathrm{Fe} /(\mathrm{Bi}, \mathrm{Sb})_{2} \mathrm{Te}_{3}$ segments sequentially hot pressed in separate dies during zero-current, $752^{\circ} \mathrm{C} / 190^{\circ} \mathrm{C} / 47^{\circ} \mathrm{C}$, thermal gradient testing

2-24. Segmented P-type element 6875-141-1 removed from test after 1100 test hours for visual examination

2-25. Seebeck coefficients of P-type $(\mathrm{Cu}, \mathrm{Ag})_{2} \mathrm{Se} / \mathrm{Fe}$ and $(\mathrm{Bi}, \mathrm{Sb})_{2} \mathrm{Te}_{3}$ segments stacked unbonded and heated with $\mathrm{T}_{\mathrm{H}}=750^{\circ} \mathrm{C}, \mathrm{T}_{\mathrm{C}}=300^{\circ} \mathrm{C}$, and $\mathrm{T}_{\mathrm{H}}=300^{\circ} \mathrm{C}, \mathrm{T}_{\mathrm{C}}=107^{\circ} \mathrm{C}$, respectively, in vacuo in zero-current test 6875-139-3

2-26. Resistivity values of P-type $(\mathrm{Cu}, \mathrm{Ag})_{2} \mathrm{Se} / \mathrm{Fe}$ and $(\mathrm{Bi}, \mathrm{Sb})_{2} \mathrm{Te}_{3}$ segments stacked unbonded and heated with $\mathrm{T}_{\mathrm{H}}=750^{\circ} \mathrm{C}, \mathrm{T}_{\mathrm{C}}=300^{\circ} \mathrm{C}$, and $\mathrm{T}_{\mathrm{H}}=300^{\circ} \mathrm{C}, \mathrm{T}_{\mathrm{C}}=107^{\circ} \mathrm{C}$, respectively, in vacuo in zero-current test 6875-139-3

2-27. Metallographic examination of a $1492-\mathrm{h}, 300^{\circ} \mathrm{C}$ interface temperature, vacuo compatibility test of unbonded $(\mathrm{Cu}, \mathrm{Ag})_{2} \mathrm{Se}$ and $(\mathrm{Bi}, \mathrm{Sb})_{2} \mathrm{Te}_{3}$ segments separated from each other by an iron barrier in a thermal gradient of $754^{\circ} \mathrm{C} / 300^{\circ} \mathrm{C} / 118^{\circ} \mathrm{C}$

2-28. Results of microprobe examinations of stacked unbonded segments of $(\mathrm{Cu}, \mathrm{Ag})_{2} \mathrm{Se} / \mathrm{Fe}$ and $(\mathrm{Bi}, \mathrm{Sb})_{2} \mathrm{Te}_{3}$ after $1492 \mathrm{~h}$ in a zero-current $754^{\circ} \mathrm{C} / 300^{\circ} \mathrm{C} / 118^{\circ} \mathrm{C}$ thermal tradient

2-29. Resistivity values for the $(\mathrm{Cu}, \mathrm{Ag})_{2} \mathrm{Se}$ segment of a doubly segmented $(\mathrm{Cu}, \mathrm{Ag})_{2} \mathrm{Se} / \mathrm{Fe} /(\mathrm{Bi}, \mathrm{Sb})_{2} \mathrm{Te}_{3}$ element $6875-146-2$ as a function of $\mathrm{iL} / \mathrm{A}$ and thermal gradient

2-30. Typical time load voltage plot showing the onset of ratcheting in $(\mathrm{Cu}, \mathrm{Ag})_{2} \mathrm{Se}$ elements

2-31. Typical $(\mathrm{Cu}, \mathrm{Ag})_{2} \mathrm{Se}$ resistivity ratcheting patterns $\mathrm{T}_{\mathrm{H}}=750^{\circ} \mathrm{C}$, $\mathrm{T}_{\mathrm{C}}=200^{\circ} \mathrm{C}$

2-32. Effect of $\mathrm{iL} / \mathrm{A}$ on the ratchet frequency of the $(\mathrm{Cu}, \mathrm{Ag})_{2}$ segment of element 6875-146-2

2-33. Dwell time for $(\mathrm{Cu}, \mathrm{Ag})_{2} \mathrm{Se}$ segment of $\mathrm{P}$ element $6875-146-2$ as a function of $\mathrm{iL} / \mathrm{A}$

2-34. Ratchet cycles of iL/A for two segmented and one unsegmented P-type elements

2-35. Effect of $\mathrm{T}_{\mathrm{C}}$ on the resistivity ratchet cycle time for $(\mathrm{Cu}, \mathrm{Ag})_{2} \mathrm{Se}$ element $6875-151-1 \mathrm{~B}$

2-36. Photomicrograph of the wire mesh $/(\mathrm{Cu} / \mathrm{Ag})_{2}$ Se joint region of sample 6875-146-2 after resistivity ratcheting experiments

2-37. Resistance change during ratcheting of $(\mathrm{Cu}, \mathrm{Ag})_{2}$ Se in segmented and unsegmented elements

2-38. Resistance change during ratcheting of the $(\mathrm{Cu}, \mathrm{Ag})_{2}$ Se segment of sample 6875-146-2

2-39. Typical voltage ramping profile showing time, temperature, and load voltage behavior of edge tack-welded mesh $(\mathrm{Cu}, \mathrm{Ag})_{2}$ Se elements operating in a thermal gradient with current

2-40. Load voltage of unsegmented $(\mathrm{Cu}, \mathrm{Ag})_{2}$ Se of element $8236-4-1 \mathrm{~A} \ldots \ldots \ldots 2-51$

2-41. Load voltage for $(\mathrm{Cu}, \mathrm{Ag})_{2}$ Se segment of element 8236-3-1B 
2-42. Resistivity values of segmented P-type element 8236-3-1B tested in a thermal gradient of $755^{\circ} \mathrm{C} / 237^{\circ} \mathrm{C} / 160^{\circ} \mathrm{C}$ at an iL/A value of 7.4 across the $(\mathrm{Cu}, \mathrm{Ag})_{2}$ Se segment

2-43. Seebeck coefficients of segmented P-type element 8236-3-1B tested in a thermal gradient of $755^{\circ} \mathrm{C} / 237^{\circ} \mathrm{C} / 160^{\circ} \mathrm{C}$ at an iL/A value of 7.4 across the $(\mathrm{Cu}, \mathrm{Ag})_{2}$ Se segment

2-44. Seebeck coefficients of unsegmented P-type element 8236-4-1A tested in a thermal gradient of $755^{\circ} \mathrm{C} / 124^{\circ} \mathrm{C}$ at an iL/A value of 7

2-45. Resistivity values of unsegmented P-type element 8236-4-1A tested in a thermal gradient of $755^{\circ} \mathrm{C} / 124^{\circ} \mathrm{C}$ at an iL/A value of 7

2-46. As-fabricated mesh-in-cap design where wire mesh only is tack welded to the hot cap

2-47. Mesh-in-cap where wire mesh only is tack-welded to the hot cap at operating temperatures

2-48. A macro view of the $\mathrm{Cu}_{2} \mathrm{Se}$ resistivity ratcheting process $\ldots \ldots \ldots \ldots \ldots 2-59$

2-49. Seebeck coefficients of P-type elements 6875-132-36 and 6825-151B .... 2-61

2-50. Resistivity values of P-type elements $6875-132-36$ and $6875-151 \mathrm{~B} \ldots \ldots \ldots 2-62$

2-51. Seebeck coefficients of the $(\mathrm{Cu}, \mathrm{Ag})_{2} \mathrm{Se}$ segment of P-type element 8236-3-1B tested in a thermal gradient of $755^{\circ} \mathrm{C} / 220^{\circ} \mathrm{C}$

2-52. Seebeck coefficients of the $(\mathrm{Bi}, \mathrm{Sb})_{2} \mathrm{Te}_{3}$ segment of P-type element 8236-3-1B tested in a thermal gradient of $220^{\circ} \mathrm{C} / 160^{\circ} \mathrm{C}$

2-53. Resistivity values of segmented P-type element 8236-3-1B tested in a thermal gradient of $755^{\circ} \mathrm{C} / 220^{\circ} \mathrm{C} / 160^{\circ} \mathrm{C}$

2-54. Resistivity values of segmented P-type element 8236-10 tested in a thermal gradient of $695^{\circ} \mathrm{C} / 45^{\circ} \mathrm{C}$

2-55. Seebeck coefficients for segmented P-type element 8236-10 tested in a thermal gradient of $695^{\circ} \mathrm{C} / 45^{\circ} \mathrm{C}$

3-1. Flowchart for preparation of $\mathrm{Nd}_{2} \mathrm{Se}_{3}$

3-2. $\mathrm{Se}_{2}$ vapor pressure over various $\mathrm{NdSe}_{\mathrm{x}}$ chunks

3-3. Low-temperature Seebeck coefficient versus $1200^{\circ} \mathrm{C} \mathrm{Se} e_{2}$ vapor pressure for $\mathrm{Nd}_{2} \mathrm{Se}_{3}$

3-4. As-fabricated low-temperature Seebeck coefficient versus resistivity for $\mathrm{Nd}_{2} \mathrm{Se}_{3}$ elements

3-5. Control of $\mathrm{NdSe}_{1.5-\mathrm{x}}$ composition and Seebeck coefficient $\ldots \ldots \ldots \ldots \ldots$ 3-13

3-6. Seebeck coefficient versus $\mathrm{Se} / \mathrm{Nd}$ ratios for melted $\mathrm{NdSe}_{1.5-\mathrm{x}}$ samples ... 3-14

3-7. Fracture surface of hot-pressed $\mathrm{NdSe}_{1.5}$ with no nickel powder additions

3-8. Fracture surface of hot-pressed $\mathrm{NdSe}_{1.5}$ plus $1 \%$ nickel $\ldots \ldots \ldots \ldots \ldots .3-18$

3-9. Seebeck coefficient of $\mathrm{NdSe}_{1.5}$ plus $1 \%$ nickel alloys $\ldots \ldots \ldots \ldots \ldots \ldots . . .22$

3-10. Flowchart for element fabrication $\ldots \ldots \ldots \ldots \ldots \ldots \ldots \ldots \ldots \ldots \ldots \ldots \ldots \ldots \ldots . .29$

3-11. Photomicrograph of $\mathrm{Nd}_{2} \mathrm{Se}_{3}$, hot pressed at $1400^{\circ} \mathrm{C}$ and post-heat treated at $1700^{\circ} \mathrm{C}$

3-12. Secont photomicrograph of $\mathrm{Nd}_{2} \mathrm{Se}_{3}$, hot pressed at $1400^{\circ} \mathrm{C}$ and post-heat treated at $1700^{\circ} \mathrm{C}$ 
3-13. Photomicrograph of $3 \mathrm{M}$ Company $\mathrm{Nd}_{2} \mathrm{Se}_{3}$ as received from Purdue University

3-14. Photomicrograph of etched $3 \mathrm{M}$ Company $\mathrm{Nd}_{2} \mathrm{Se}_{3}$ as received from Purdue University

3-15. Scanning electron microscopy photomicrograph of GA hot-pressed and annealed $\mathrm{Nd}_{2} \mathrm{Se}_{3}$ showing very dense structure

3-16. Scanning electron microscopy photomicrograph of 3M Company cold-pressed and sintered $\mathrm{Nd}_{2} \mathrm{Se}_{3}$ as received from Purdue University

3-17. $\mathrm{Nd}_{2} \mathrm{Se}_{3}$ hot pressed with W-26/Re wire mesh

3-18. Photomicrograph of the graded $\mathrm{Mo} / \mathrm{Nd}_{2} \mathrm{Se}$ and $\mathrm{W}-26 /$ Re mesh joint of $\mathrm{N}$-type element 7958-84-1

3-19. $\mathrm{Nd}_{2} \mathrm{Se}_{3}$ hot pressed with a Mo-Re cap

3-20. Compression hot-cap-to-element joint

3-21. Compression flexible metal-to-element joint

$3-46$

3-22. Flexible metal-to-N-element joint

4-1. Couple 7958-109

4-2. Seebeck coefficient as a function of average temperature for $\mathrm{N}$ leg of couple 7958-109

4-3. Resistivity as a function of average temperature for $\mathrm{N}$ leg of couple 7958-109

4-4. P leg of couple test 7958-109

4-5. $\quad \mathrm{N}$ leg of couple test 7958-109

4-6. Transfer of stress through a too stiff current strap

4-7. Module test 7958-133

\section{TABLES}

2-1. Effectiveness of thin film coatings on stainless steel to prevent corrosive reaction between stainless steel hot caps and $(\mathrm{Cu}, \mathrm{Ag})_{2} \mathrm{Se}$

2-2. Vapor suppression summary

2-3. Segmented P-element isothermal compatibility test summary, stability of Seebeck coefficients

3-1. GA method 1: $\mathrm{NdSe}_{1.5}$ alloy development through control of starting alloy composition

3-2. $\mathrm{NdSe}_{1.5}$ alloy development, Ames Laboratory techniques for $\mathrm{NdSe}_{1.5}$ production

3-3. GA method $1 \mathrm{Nd}_{2} \mathrm{Se}_{3}$ alloy development

3-4. Method $1 \mathrm{Nd}_{2} \mathrm{Se}_{3}$ alloy development evaluation

3-5. $\quad \mathrm{Nd}_{2} \mathrm{Se}_{3}$ melting trials

3-6. $\mathrm{NdSe}_{1.5}$ process controls

3-7. $\quad \mathrm{Nd} / \mathrm{Se}$ measurements 


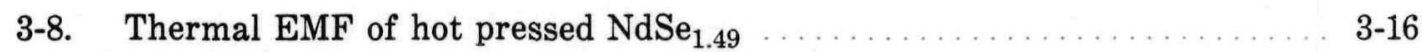

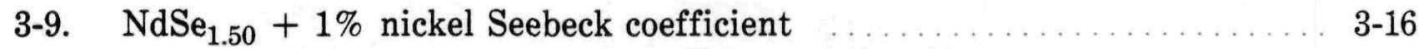

3-10. Seebeck coefficient of $\mathrm{NdSe}_{1.5}$ and $\mathrm{NdSe}_{1.5}+1 \%$ nickel alloys ....... 3-19

3-11. $\mathrm{NdSe}_{1.5-\mathrm{x}}$ properties after aging at $1000^{\circ} \mathrm{C} \ldots \ldots \ldots \ldots \ldots \ldots \ldots \ldots \ldots$

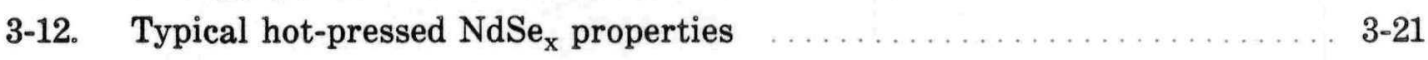

3-13. Hot pressing additives for $\mathrm{NdSe}_{1.495} \quad \ldots \ldots \ldots \ldots \ldots \ldots \ldots \ldots \ldots \ldots \ldots \ldots \ldots \ldots \ldots$

3-14. In-gradient testing of $\mathrm{Nd}_{2} \mathrm{Se}_{3}+1 \% \mathrm{Cr} \quad \ldots \ldots \ldots \ldots \ldots \ldots \ldots \ldots \ldots \ldots \ldots$

3-15. Aging effects on $\mathrm{NdSe}_{1.495}$ matrix alloys $\ldots \ldots \ldots \ldots \ldots \ldots \ldots \ldots \ldots \ldots .24$

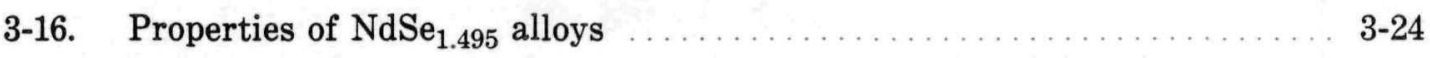

3-17. Seebeck coefficient of $\mathrm{NdSe}_{1.45}+0.5 \% \mathrm{~W}+0.5 \% \mathrm{Cr}(7958-48-3) \ldots \ldots .3-26$

3-18. Results on hot-pressed $(\mathrm{Nd}, \mathrm{Gd}) \mathrm{Se}_{1.5}$ alloys $\ldots \ldots \ldots \ldots \ldots \ldots \ldots \ldots \ldots \ldots$

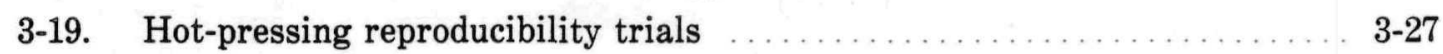

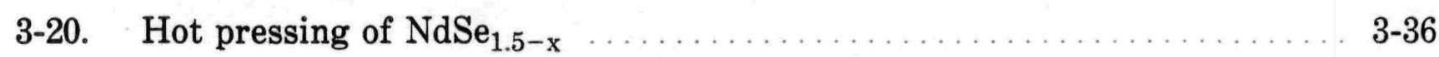

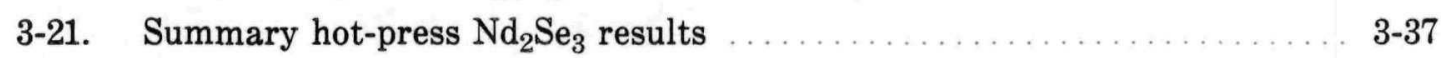

3-22. Effect of hot pressing additives on the thermal electric properties of

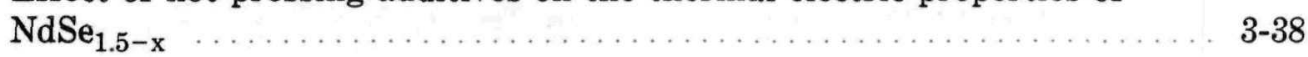

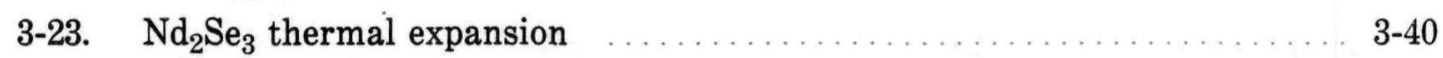

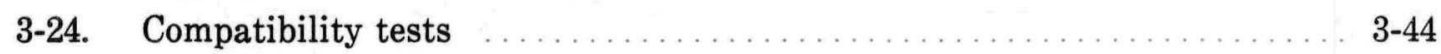




\section{INTRODUCTION}

General Atomic (GA) conducted a program to develop selenide thermoelectric materials to improve the performance and useful life of $\mathrm{P}$-type $(\mathrm{Cu}, \mathrm{Ag})_{2} \mathrm{Se}$ and $\mathrm{N}$-type rare earth selenide thermoelectric materials for the Department of Energy (DOE).

The studies on $(\mathrm{Cu}, \mathrm{Ag})_{2} \mathrm{Se}$ and rare earth selenide materials are generally intended to develop a high-temperature radioisotope thermoelectric generator (RTG) achieving efficiencies of $\geq 10 \%$. These efficiencies could presumably be obtained with the GA design (radiation-coupled, many-parallel-circuit, 3.4-W/lb) or with designs pursued by other contractors.

The emphasis of the Isotec Technology Program shifted from the development of a Galileo generator to the study of a segmented selenide element and of couple technology. Originally, the program was to determine the feasibility of fabricating segmented selenide $\mathrm{P}$ and $\mathrm{N}$ elements which exploit the high thermoelectric efficiency of $(\mathrm{Cu}, \mathrm{Ag})_{2} \mathrm{Se}$ and $\mathrm{Gd}_{2} \mathrm{Se}_{3}$ materials. A preliminary evaluation of segmented element efficiencies, material compatibilities, and fabrication abilities was used to select $(\mathrm{Cu}, \mathrm{Ag})_{2} \mathrm{Se} / \mathrm{Fe} /(\mathrm{Bi}, \mathrm{Sb})_{2} \mathrm{Te}_{3}$ for the $\mathrm{P}$ element and $\mathrm{Gd}_{2} \mathrm{Se}_{3} / \mathrm{PbTe}$ for the $\mathrm{N}$ element. An iron barrier between the $(\mathrm{Cu}, \mathrm{Ag})_{2} \mathrm{Se}$ and $(\mathrm{Bi}, \mathrm{Sb})_{2} \mathrm{Te}_{3}$ prevented thermoelectric properties from degrading due to copper contamination of the $(\mathrm{Bi}, \mathrm{Sb})_{2} \mathrm{Te}_{3}$.

Processes for fabricating both elements were developed, but the $(\mathrm{Cu}, \mathrm{Ag})_{2} \mathrm{Se}$ hot cap design needed improvement. Also, $\mathrm{Gd}_{2} \mathrm{Se}_{3}$ was friable and difficult to fabricate crack free. It exhibited a phase transition from cubic to orthorhombic at processing temperatures. The phase transition increased its susceptibility to microcracking and reduced its thermoelectric efficiency.

Life testing of an all-bonded couple with unsegmented $(\mathrm{Cu}, \mathrm{Ag})_{2} \mathrm{Se} \mathrm{P}$-type and $\mathrm{Gd}_{2} \mathrm{Se}_{3} \mathrm{~N}$-type elements was performed for $3300 \mathrm{~h}$ in a nominal $830^{\circ} / 390^{\circ} \mathrm{C}$ thermal gradient. The $\mathrm{Gd}_{2} \mathrm{Se}_{3}$ leg did not show any significant degradation during the test. Examination of the hot end of the $\mathrm{P}$ element showed the need for a less reactive hot cap material and an improved vapor suppression system. Thus, the general class of materials, the rare earth selenide $\mathrm{N}$ leg and $(\mathrm{Cu}, \mathrm{Ag})_{2} \mathrm{Se} \mathrm{P}$-type leg, appears correct for a thermoelectric stability.

The phase transition which occurs in $\mathrm{Gd}_{2} \mathrm{Se}_{3}$ near its processing and operating temperature is not easily circumvented. The choices are either to process and operate at a lower temperature or to change the material. Since lowering the operating temperature would defeat the reason for selecting $\mathrm{Gd}_{2} \mathrm{Se}_{3}$, other N-type selenide materials were investigated. One choice would be a mixed rare earth selenide which includes gadolinium. Another would be a rare earth selenide which has thermoelectric properties approaching that of $\mathrm{Gd}_{2} \mathrm{Se}_{3}$ but which is single phase at the processing and operating temperature. 
$\mathrm{Nd}_{2} \mathrm{Se}_{3}$ meets these criteria. The goal of the FY 80-81 program was thus to continue evaluating $(\mathrm{Cu}, \mathrm{Ag})_{2} \mathrm{Se}$ as the high-temperature segment of a P-type thermoelectric element and $\mathrm{Nd}_{2} \mathrm{Se}_{3}$ as the high-temperature segment of an $\mathrm{N}$-type thermoelectric element. Together, these form a high-efficiency thermoelectric couple. 


\section{SEGMENTED P-TYPE ELEMENT STUDIES}

In this reporting period, the study on the segmented P-type element was primariiy directed toward $(\mathrm{Cu}, \mathrm{Ag})_{2} \mathrm{Se} / \mathrm{Fe} /(\mathrm{Bi}, \mathrm{Sb})_{2} \mathrm{Te}_{3}$ in the configuration shown in Fig. 2-1. A fabrication sequence was developed in FY 79 which made mechanically strong segmented elements with a barrier of iron across the element to prevent copper from contaminating the $(\mathrm{Bi}, \mathrm{Sb})_{2} \mathrm{Te}_{3}$ segment. These elements still had inconsistent thermoelectric properties. One goal of this effort was to find and correct the cause of these inconsistencies. Another was to examine methods to prevent elements from the hot cap from diffusing into the $(\mathrm{Cu}, \mathrm{Ag})_{2} \mathrm{Se}$ segment. These efforts were part of a general evaluation of techniques to optimize the useful operating temperature and life of the segmented P-type element.

\subsection{FABRICATION DEVELOPMENT OF SEGMENTED P-TYPE ELEMENTS}

\subsubsection{Hot Pressing Modification}

Examination of segmented P-type elements prepared by processes developed in FY 79 showed copper contamination of the outer surface of $(\mathrm{Bi}, \mathrm{Sb})_{2} \mathrm{Te}_{3}$ segments and the iron barrier. This contamination resulted primarily from worn dies containing copper inclusions. Thus, hot pressed segments of $(\mathrm{Bi}, \mathrm{Sb})_{2} \mathrm{Te}_{3}$ had low Seebeck values when processed in these dies. Contamination occurred in both one- and two-step hot pressing of the segmented $\mathrm{P}$ element.

The following measures to overcome this copper were successful:

1. Worn die inserts were replaced with newly purchased tungsten-carbide (WC) inserts.

2. Dies used for hot pressing $(\mathrm{Cu}, \mathrm{Ag})_{2} \mathrm{Se}$ were not used to hot press $(\mathrm{Bi}, \mathrm{Sb})_{2} \mathrm{Te}_{3}$.

3. $(\mathrm{Cu}, \mathrm{Ag})_{2} \mathrm{Se}$ segments placed in dies during the $(\mathrm{Bi}, \mathrm{Sb})_{2} \mathrm{Te}_{3}$ hot pressing were given a thorough precleaning to remove residual surface copper.

Thus, the key change in the fabrication sequence shown in Fig. 2-2 is that a different die is used to hot press the $(\mathrm{Bi}, \mathrm{Sb})_{2} \mathrm{Te}_{3}$ segment than is used to hot press the $(\mathrm{Cu}, \mathrm{Ag})_{2} \mathrm{Se}$ segment. This eliminated contamination of the $(\mathrm{Bi}, \mathrm{Sb})_{2} \mathrm{Te}_{3}$ segment during fabrication of the element. Section 2.2.2 gives the results of test evaluations of this concept. 


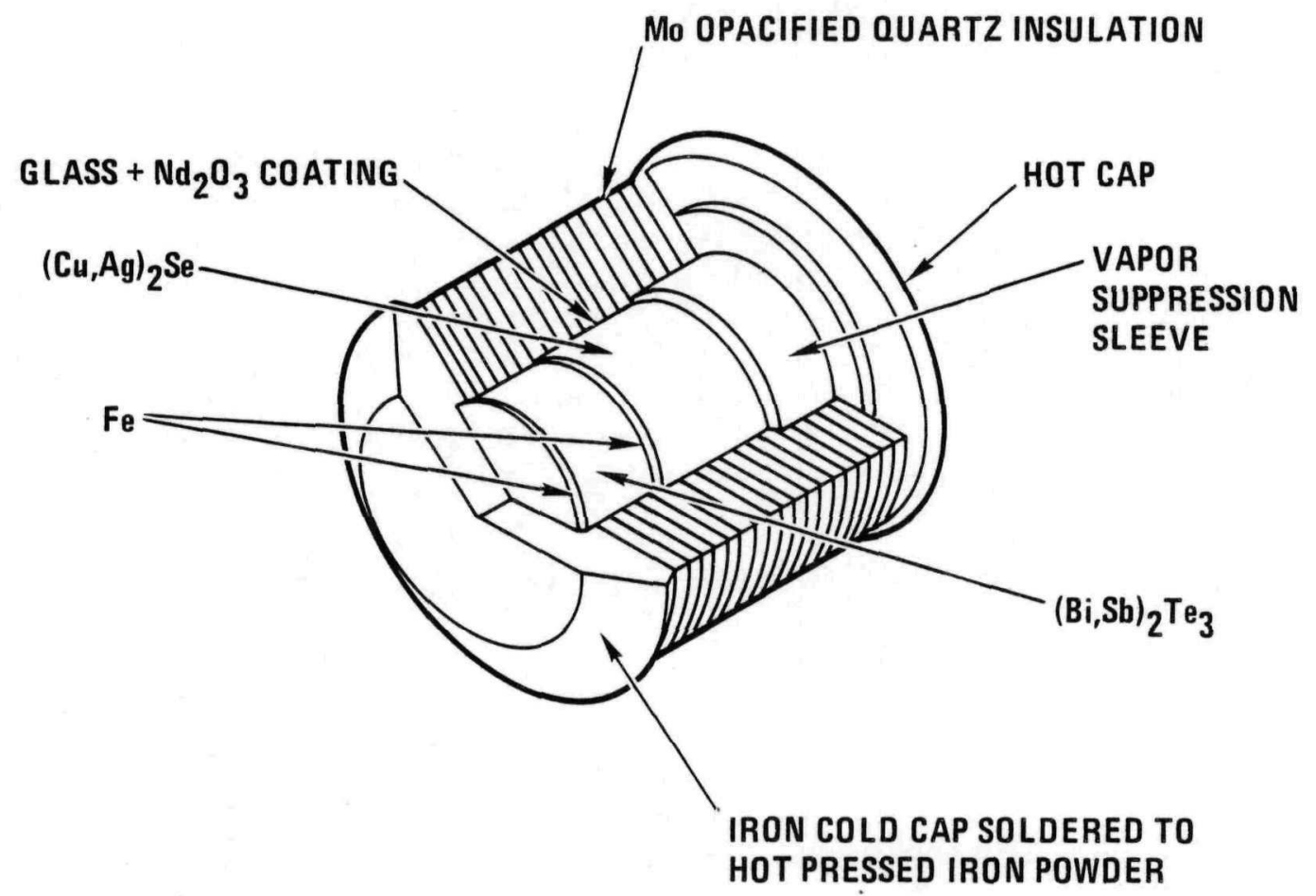

Fig. 2-1. Segmented $P$ element $(C u, A g)_{2} \mathrm{Se} /(B i, S b)_{2} \mathrm{Te}_{3}$ 


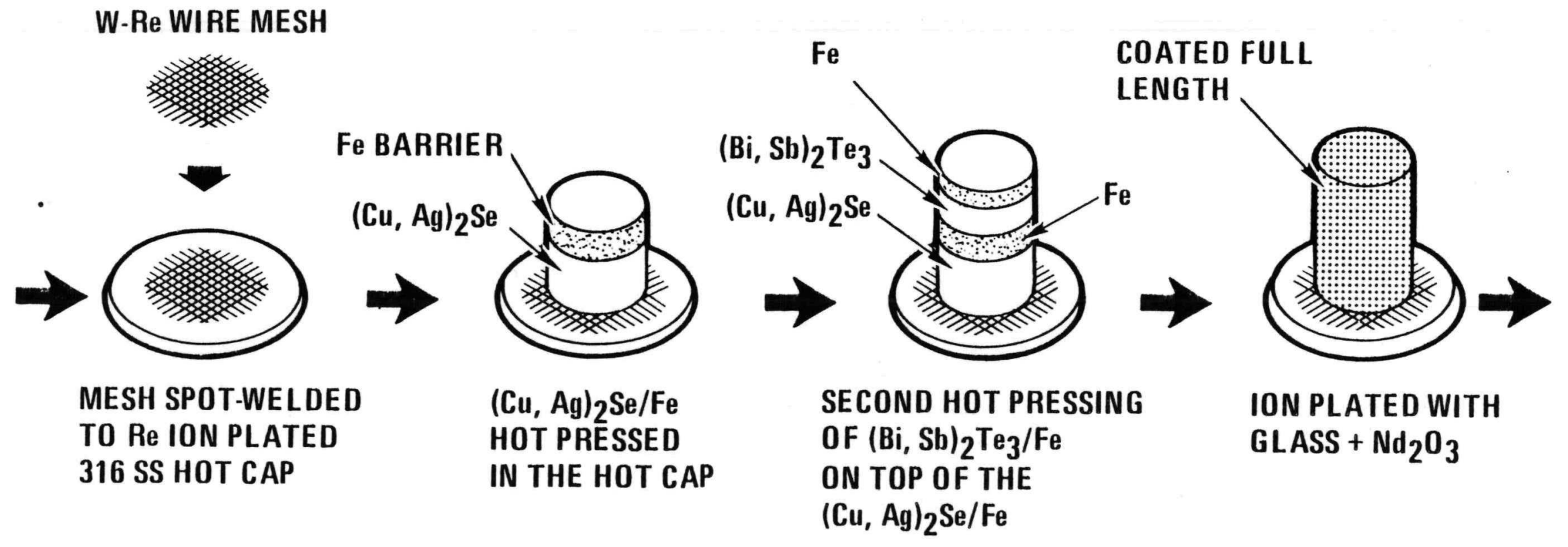

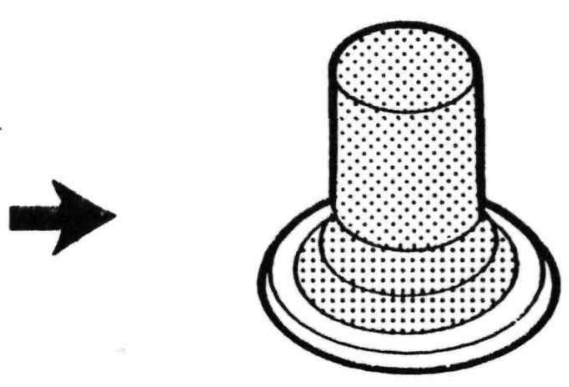

VAPOR SUPPRESSION SLEEVE JOINED TO HOT CAP

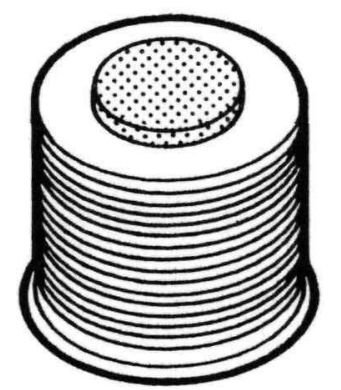

Mo OPACIFIED INSULATION ADDED
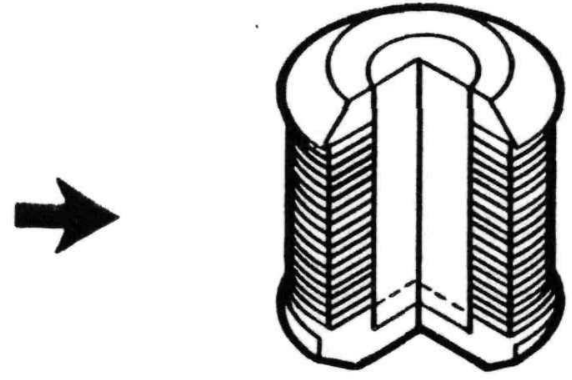

Fe COLD CAP SOLDERED TO IRON SHOE Fig. 2-2. Fabrication sequence for the preparation of $(C u, A g)_{2}, S e /(B i, S b), T e_{;}$, segmented
elements 


\subsubsection{Mo-Re Hot Caps}

All gradient life tests of stainless-steel hot caps showed a corrosive reaction between the stainless steel and $(\mathrm{Cu}, \mathrm{Ag})_{2} \mathrm{Se}$. This generally resulted in the transport of iron, chromium, and nickel down the thermal gradient. Molybdenum, tungsten, and rhenium coatings were used to coat the stainless steel to prevent these elements from diffusing. Even when the coating appeared impermeable, as the magnified view seen in Fig. 2-3 shows, the diffusion of iron, chromium, and nickel was slowed but not prevented. Table 2-1 summarizes the experimental findings on the thin film barrier coatings. Thin foil metal inserts were tried, as shown in Fig. 2-4, between the $(\mathrm{Cu}, \mathrm{Ag})_{2} \mathrm{Se}$ and the stainless-steel cap. The foil barriers were difficult to fabricate, and stainless-steel-to- $(\mathrm{Cu}, \mathrm{Ag})_{2} \mathrm{Se}$ contact around the element edges could not be prevented. The investigators then decided to use a refractory metal hot cap. Tungsten and molybdenum caps were avoided because of joining difficulties to collectors and interelement current straps. Molybdenum-rhenium alloys were chosen as the hot cap materials. The first Mo-47/Re hot caps for P-type selenide elements were made from Teledyne-supplied 254- $\mu \mathrm{m}$ (10-mil) thick Mo-47/Re sheet stock dimpled to accommodate the GA mesh-bonded cap concept. The wire mesh used for this joint was made from W-26/Re $0.76-\mathrm{cm}(0.003$-in.) wire. Tack welding the $\mathrm{W}-26 / \mathrm{Re}$ wire to the Mo-47/Re cap was more difficult than tack welding it to stainless steel, but the joints were adequate. Figure 2-5 shows the Mo-47/Re foil hot cap on a doubiy segmented $(\mathrm{Cu}, \mathrm{Ag})_{2} \mathrm{Se} / \mathrm{Fe} /(\mathrm{Bi}, \mathrm{Sb})_{2} \mathrm{Te}_{3}$ element.

\subsubsection{Hot Cap to $(\mathrm{Cu}, \mathrm{Ag})_{2} \mathrm{Se}_{3}$ Joint}

Hot-cap-to-element joints in both the $\mathrm{P}$ and $\mathrm{N}$ elements have been revised. This effort was intended to minimize wires external to the hot cap which form channels for vaporization. The wires on the bottom side of the hot cap were originally intended to help hold the bonded vapor supression glass sleeve. In the newer vapor suppression concept, a locking metal washer holds the vapor suppression sleeve; thus, the external wires are no longer needed.

The W-26 wires were diffusion-bonded to the Mo-50/Re hot cap, as shown in Fig. 2-6. Overhang wires were folded inward to increase the wire-element contact area. Diffusion bonding of the wires was successfully accomplished (Fig. 2-7). An as-fabricated element made with the diffusion-bonded wire mesh was mounted and polished. The mount showed the wires to be encapsulated in the $(\mathrm{Cu}, \mathrm{Ag})_{2} \mathrm{Se}$ material where the wires were not touching the hot cap surface. The diffusion and hot pressing steps collapsed most of the space between the wire mesh and hot cap surface. Figure 2-8 schematically shows several other configurations examined of the joint between the wire mesh and the hot cap.

Configuration $1 \mathrm{~A}$ was used in the first segmented couples. Resistivity values of the first P element of the first couple became cyclic then erratic after 190 test hours. Element examination after 400 test hours showed joint loss between the mesh and $(\mathrm{Cu}, \mathrm{Ag})_{2} \mathrm{Se}$. This loss was attributed to a loss of copper in $(\mathrm{Cu}, \mathrm{Ag})_{2} \mathrm{Se}$ due to current flow, $\mathrm{Se}_{2}$ loss, and differential expansion between the $\mathrm{N}$ and $\mathrm{P}$ legs of the couple. Configurations $1 \mathrm{~B}$ and 


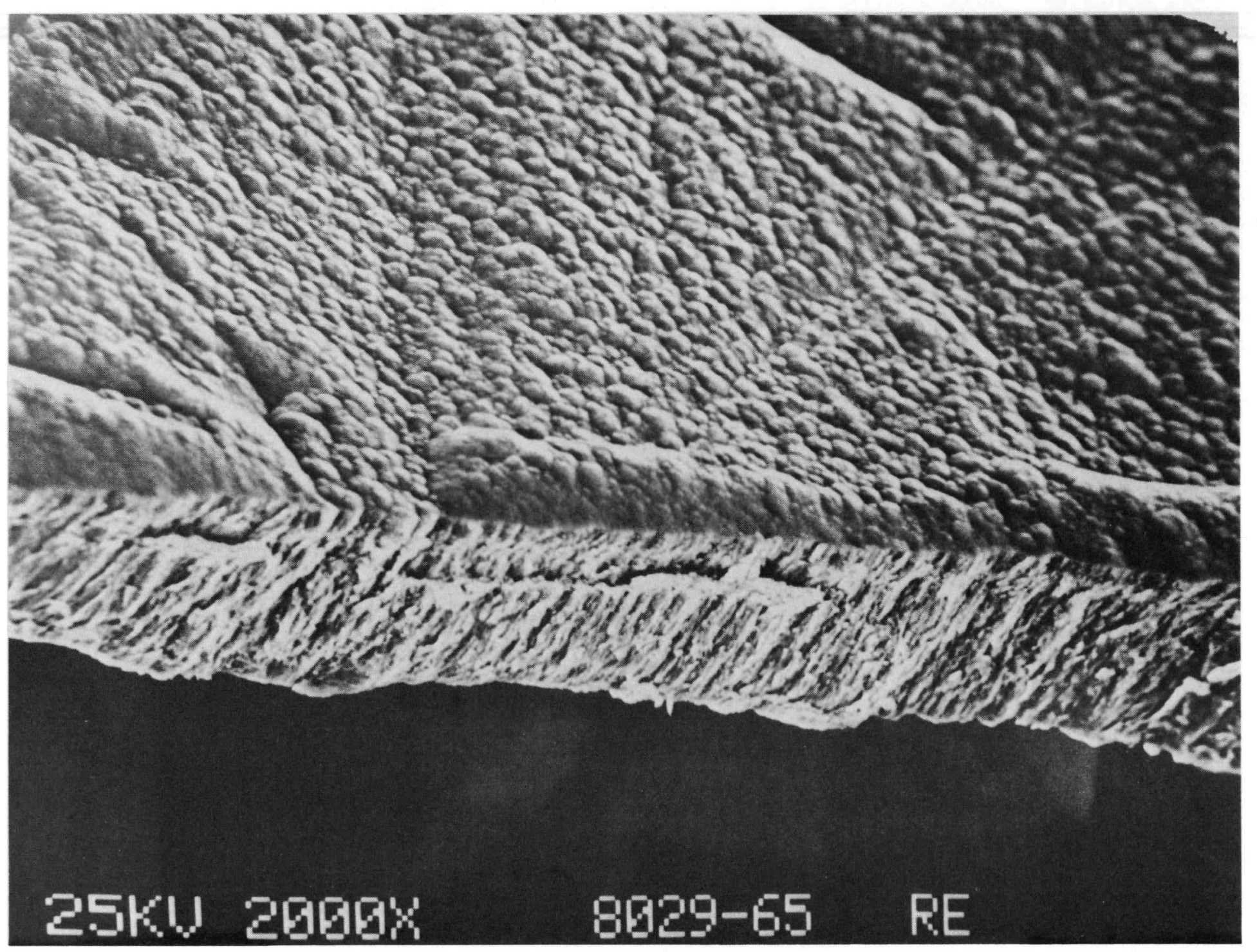

Fig. 2-3. Scanning electron photomicrograph of the ion-plated rhenium coating, run 8029-65, on 316 stainless steel 


\section{TABLE 2-1}

\section{EFFECTIVENESS OF THIN FILM COATINGS ON STAINLESS STEEL TO PREVENT CORROSIVE REACTION BETWEEN STAINLESS STEEL HOT CAPS AND $(\mathrm{Cu}, \mathrm{Ag})_{2} \mathrm{Se}$ \\ Coating \\ Effect}

Molybdenum

Tungsten

Rhenium
Will not react with $(\mathrm{Cu}, \mathrm{Ag})_{2}$ Se directly but showed a strong reaction in the presence of chromium

Nonreactive with $(\mathrm{Cu}, \mathrm{Ag})_{2} \mathrm{Se}$, but microcracks allow coatings to be breached and eventually lost

No reaction with $(\mathrm{Cu}, \mathrm{Ag})_{2} \mathrm{Se}$ evident, more ductile than tungsten and less likely to form microcracks, but did not prevent the reaction between the stainless steel cap and $(\mathrm{Cu}, \mathrm{Ag})_{2} \mathrm{Se}$ 

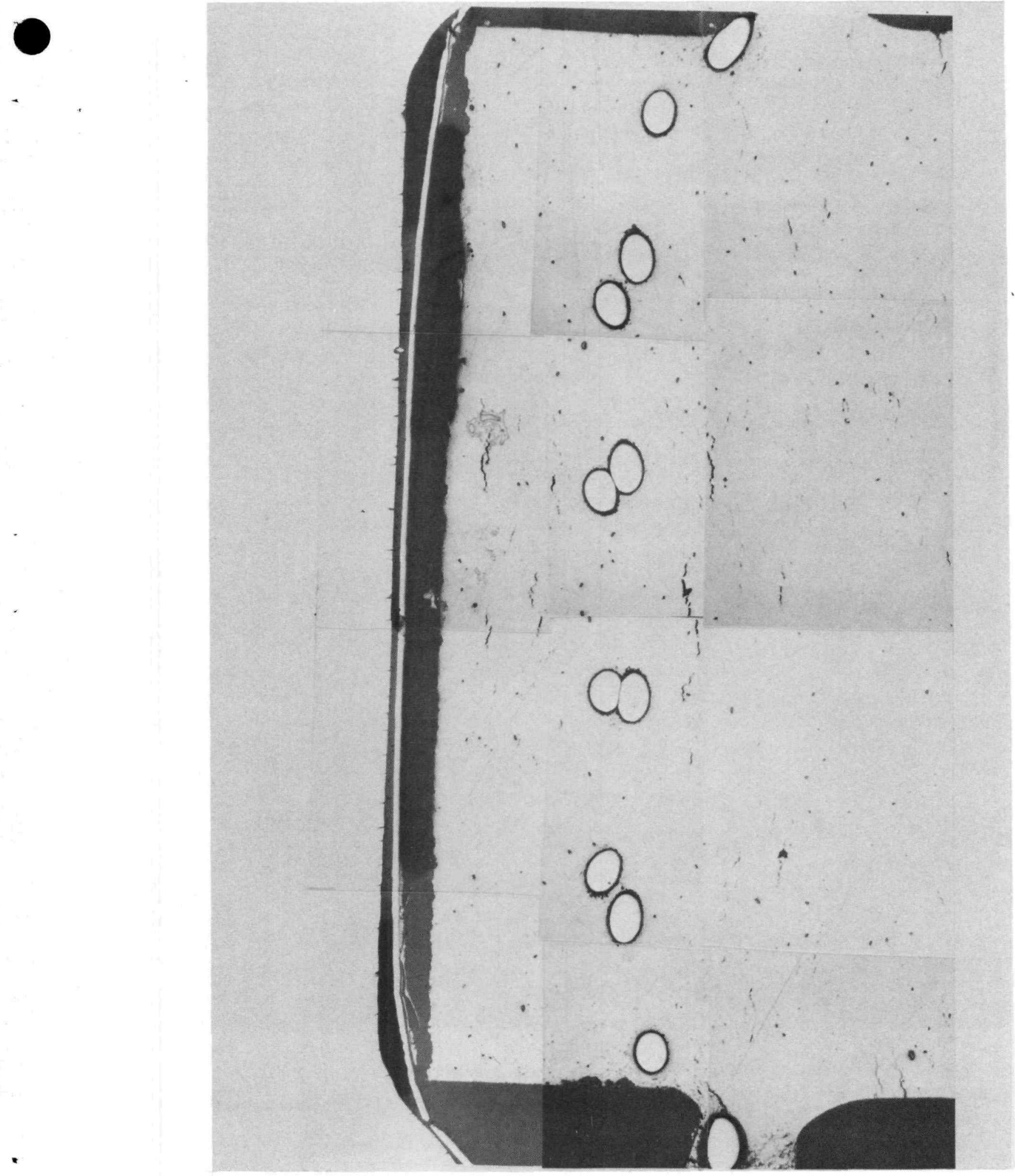

Fig. 2-4. Nickel hot cap/tungsten foil/(Cu, Ag).2 Se (sample 6875-110-24) after $172 \mathrm{~h}$ at $750^{\circ} \mathrm{C}$ 


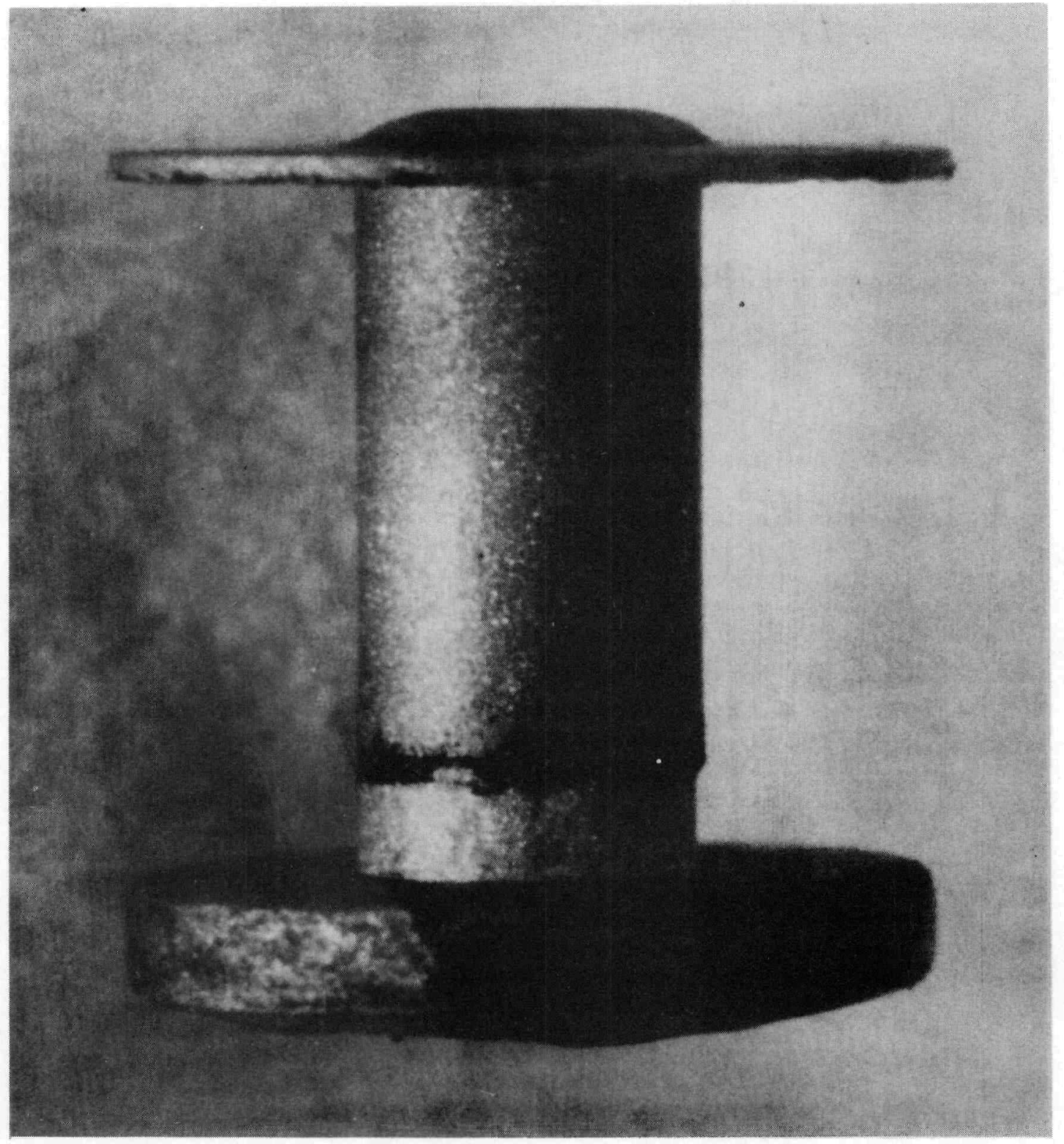

Fig. 2-5. Macro view of a $(\mathrm{Cu}, \mathrm{Ag})_{2} \mathrm{Se} /(\mathrm{Bi}, \mathrm{Sb})_{2} \mathrm{Te}_{3}$ segmented element with a Mo-47/Re hot cap 


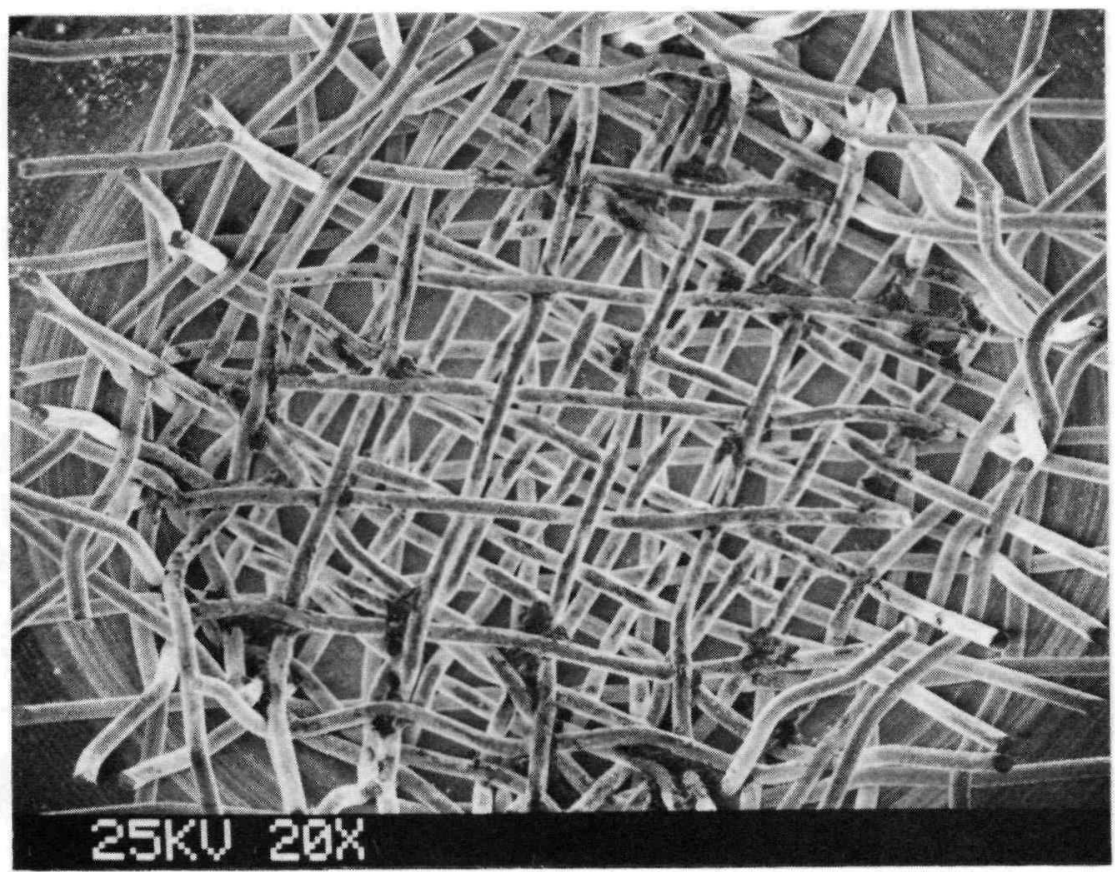

Fig. 2-6. Diffusion-bonded W-26/Re mesh in a Mo-50/Re cap as fabricated (7958-83-1) 


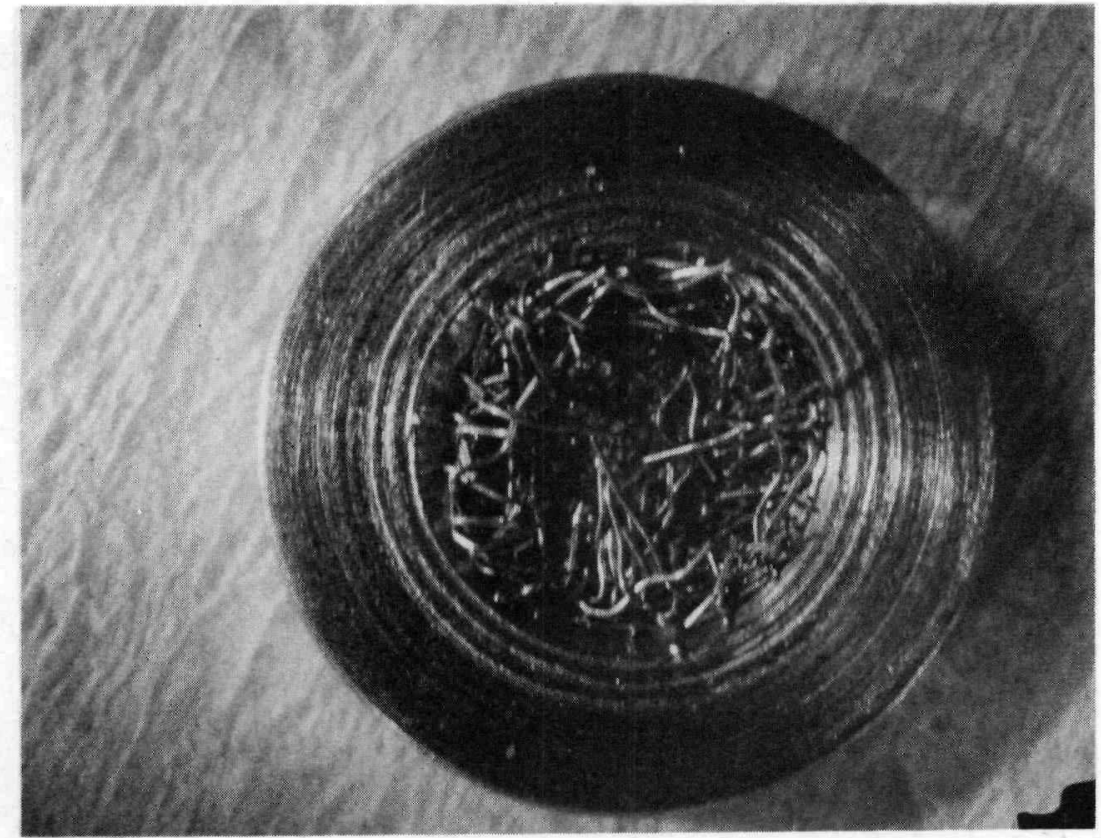

Fig. 2-7. Diffusion-bonded W-26/Re mesh in a Mo-50/Re cap with wire ends folded inward ready for element hot pressing (7958-83-1) 

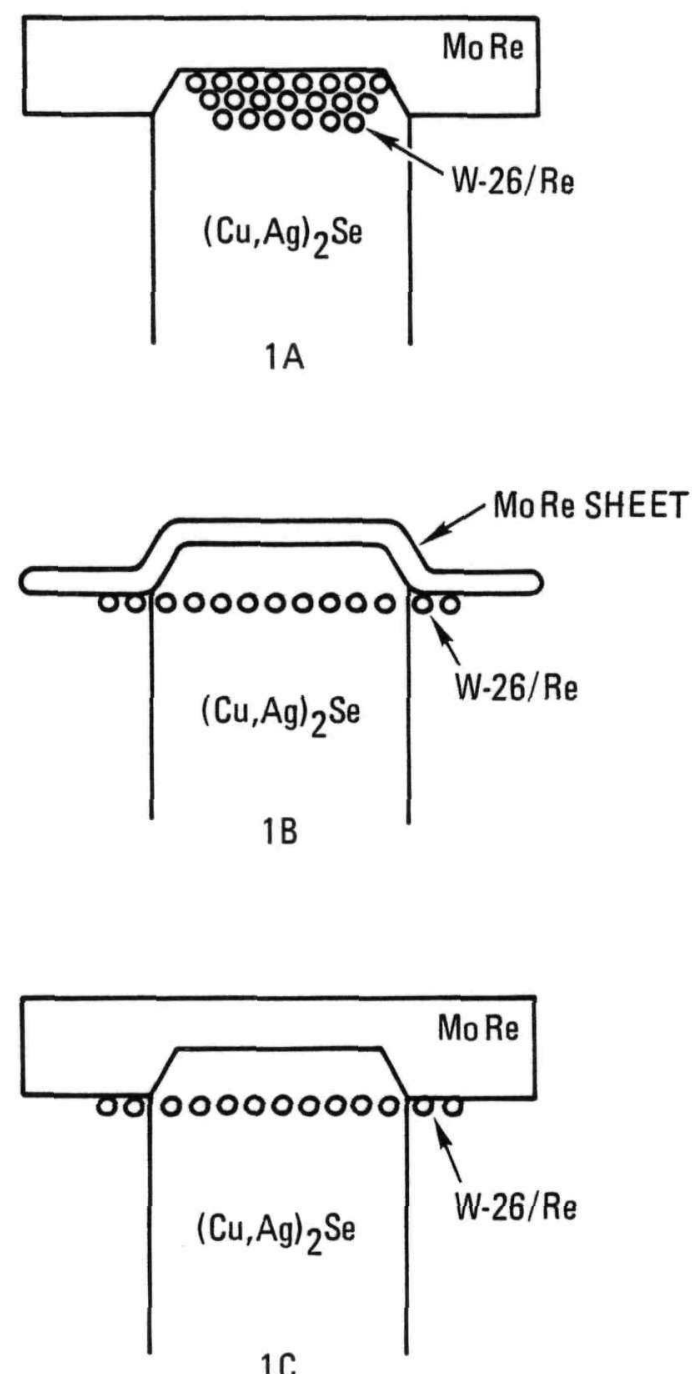

Fig. 2-8. Hot cap to $(\mathrm{Cu}, \mathrm{Ag})_{2}$ Se joint configurations 
1C accommodate the differential thermal expansion of hot cap and element materials better than configuration 1A. Configuration $1 \mathrm{~B}$ is the joint used in element test 8236-3= 13 which had $6356 \mathrm{~h}$ at $755^{\circ} \mathrm{C}$ at an iL/A of 7.4 through the $(\mathrm{Cu}, \mathrm{Ag})_{2} \mathrm{Se}$ segment before it was removed from testing. This element was made by hot pressing the element with the wire embedded in it, then tack welding the wire to the $2.54-\mathrm{cm}(0.010$-in.) thick Mo$47 /$ Re hot cap.

A modification of configuration $1 \mathrm{C}$ is recommended for future $(\mathrm{Cu}, \mathrm{Ag})_{2} \mathrm{Se}$ metallurgical joints for thermoelectric P-type elements. The wire mesh is encapsulated in the element first during hot pressing, as shown in Fig. 2-9. It is then removed from the hot press (Fig. 2-10) and tack-welded to the machined hot cap.

\subsubsection{Vapor Suppression}

The GA concept for vapor suppression has evolved into a multibarrier system schematically shown in Fig. 2-11 and summarized in Table 2-2. The baffling factors quoted for the $\mathrm{Nd}_{2} \mathrm{O}_{3}$ and Pyrex coating were experimentally determined. Baffling factors for the vapor suppression sleeve are theoretical estimates made earlier in this program. Baffling factors for the molybdenum-opacified quartz insulation came from experimental examination of the same materials and designs used in other programs to develop thermoelectric materials.

Figures 2-12 through 2-14 show three P-type segmented element designs evaluated for the hot cap joint and locking vapor suppression sleeve inclusion. Electrical contact was lost in the configuration in Fig. 2-12 in less than $200 \mathrm{~h}$ at temperature in a thermal gradient with current flowing. Metallographic examinations showed gaps between the $(\mathrm{Cu}, \mathrm{Ag})_{2} \mathrm{Se}$ and the wire mesh. The gap is caused by the rigid configuration of the compressed and diffusion-bonded wire mesh. The rigidity of the configuration could not accommodate differential thermal expansions between the hot cap and $(\mathrm{Cu}, \mathrm{Ag})_{2} \mathrm{Se}$ materials.

The wire mesh configurations shown in Figs. 2-13 and 2-14 accommodate differential thermal expansions between the hot cap and $(\mathrm{Cu}, \mathrm{Ag})_{2} \mathrm{Se}$ materials, as life tests have shown. Since the configuration in Fig. 2-13 was much more difficult to fabricate, it was abandoned in favor of that shown in Fig. 2-14. Figure 2-14 also shows the element in its normal configuration in a test thermoelectric couple.

Quartz was chosen as the vapor suppression sleeve material for these elements. Design optimization studies are needed to determine the sleeve dimensions for each material selected for this application. This optimization is necessary to maximize the vapor suppression but to minimize heat transfer and element efficiency loss. Since these analyses were not within the scope of this program, the sleeve dimensions were arbitrarily selected. 


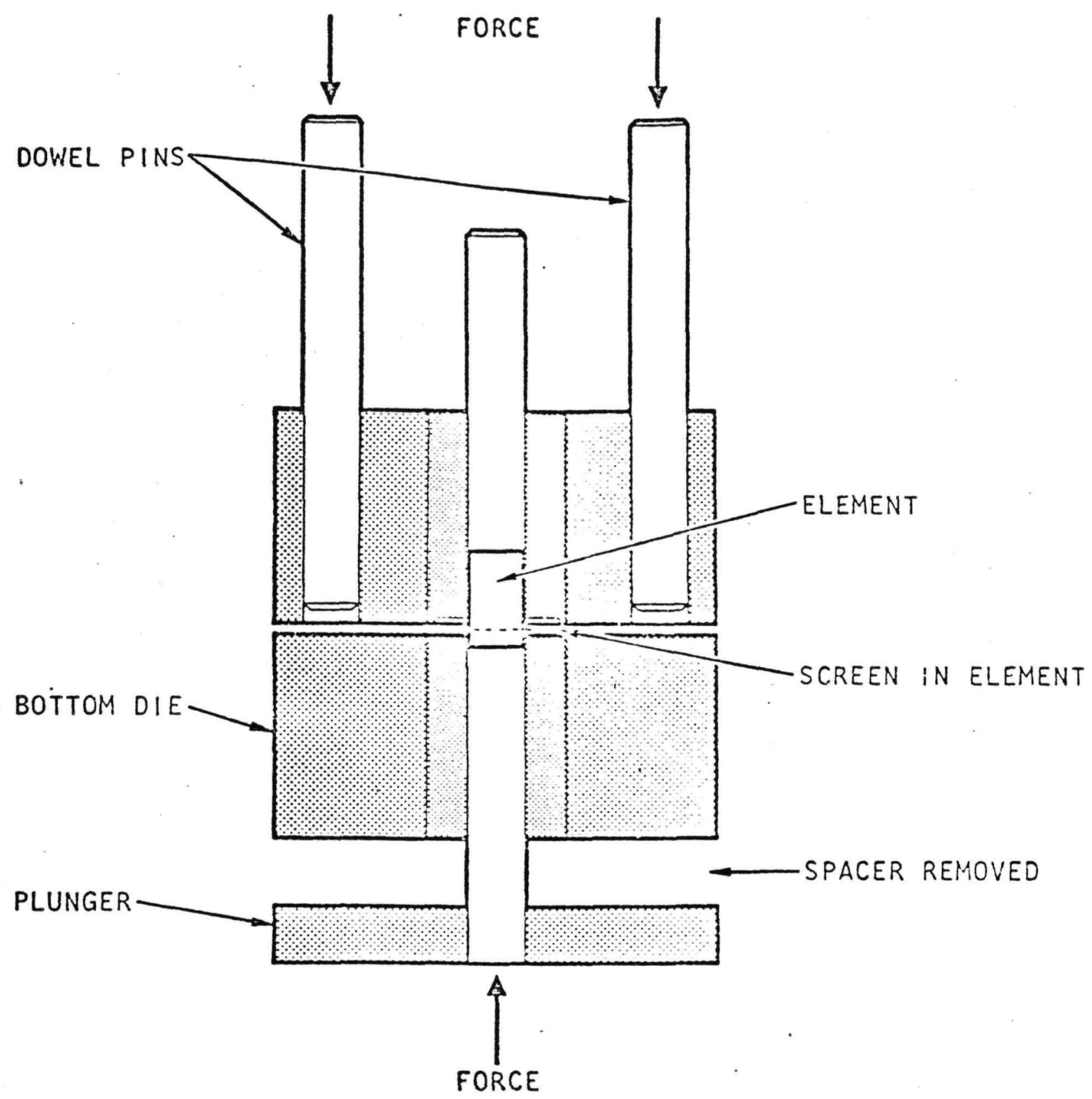

Fig. 2-9. Pushing the bottom die off the element 


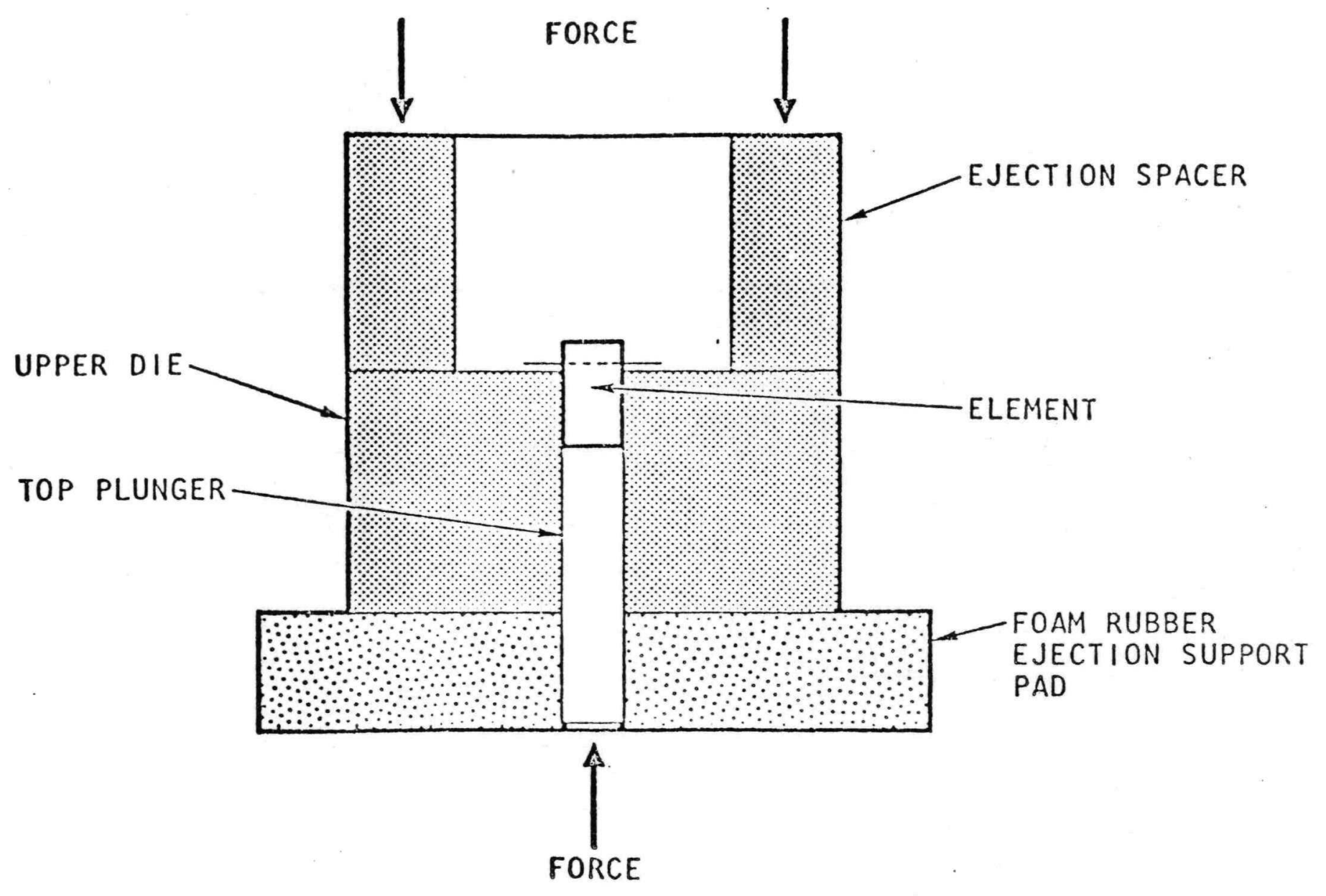

Fig. 2-10. Pressing element out of upper die 


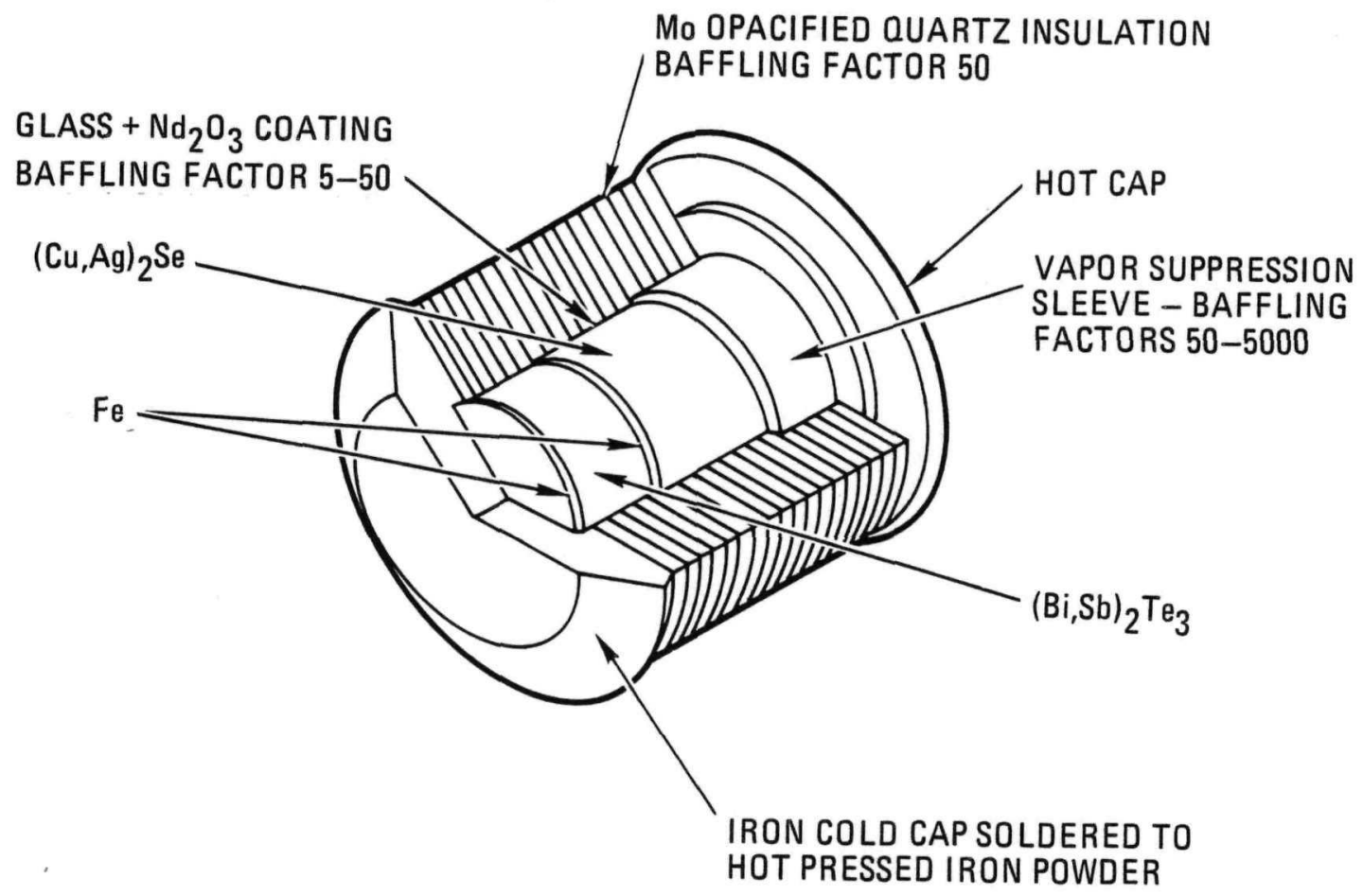

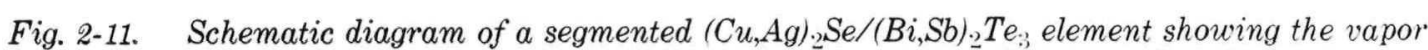
suppression sleeve, coating, and insulation with their effective baffling factors 


\section{TABLE 2-2 \\ VAPOR SUPPRESSION SUMMARY}

\section{Coatings on $(\mathrm{Cu}, \mathrm{Ag})_{2} \mathrm{Se}$}

Glass plus $\mathrm{Pr}_{2} \mathrm{O}_{3}$ or $\mathrm{Nd}_{2} \mathrm{O}_{3}$, ion plated, baffling factor $>10$

$\mathrm{Cr}_{\mathrm{x}} \mathrm{O}_{\mathrm{y}}$, baffling factor $>20$ promising coating

\section{Vapor suppression sleeve}

Glass bonded to hot cap through mesh interface, baffling factor $>50$

$\mathrm{SiO}_{2}$ sleeve held in place with a welded metal collar, baffling factor $>50$

\section{Element insulation}

Molybdenum-opacified quartz paper washers, baffling factor of 50, presently used on all elements 


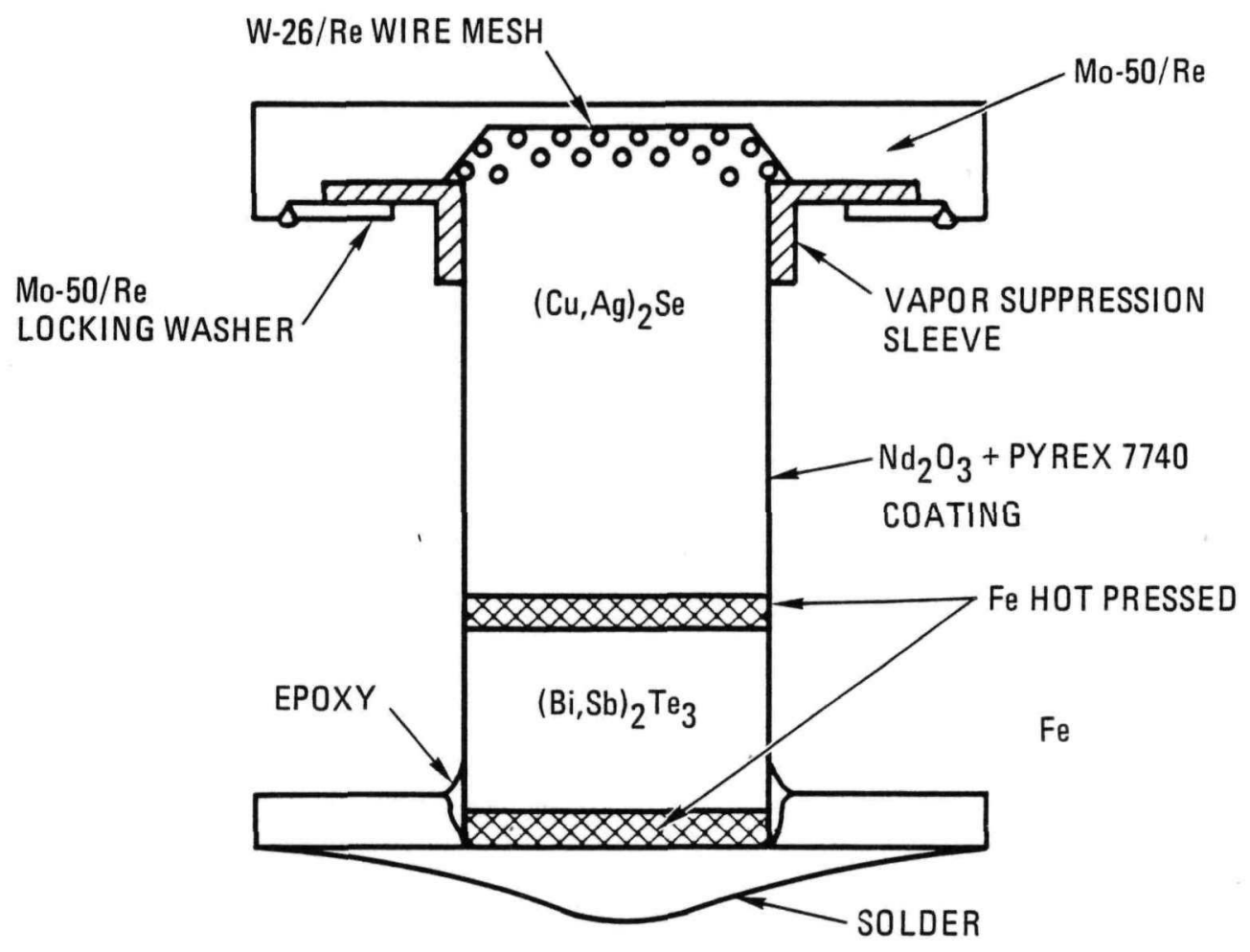

Fig. 2-12. Schematic diagram of a segmented $P$ element with the $W$-26/Re wire mesh tackwelded to the center of a one-piece Mo-Re hot cap 


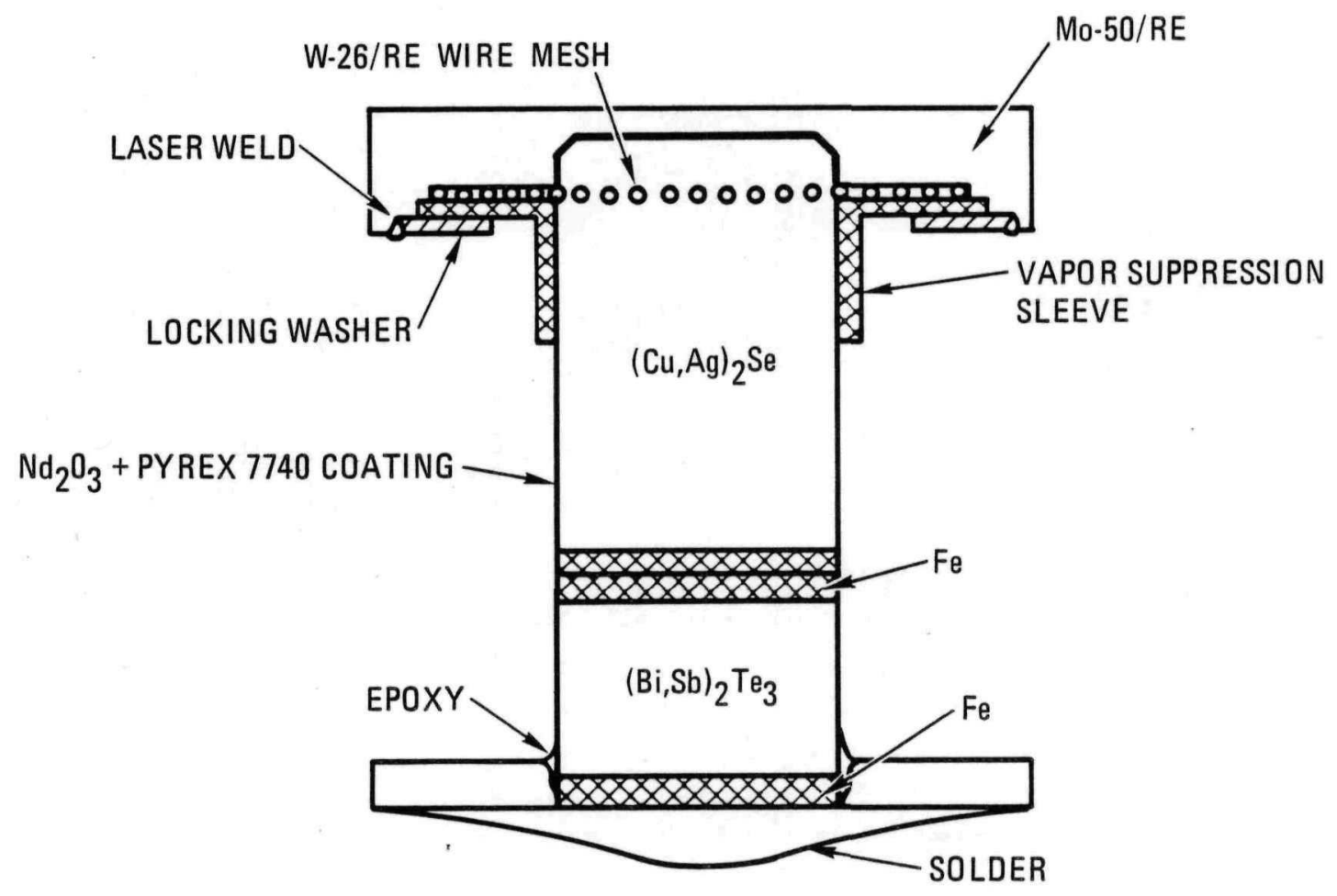

Fig. 2-13. Schematic diagram of a segmented $P$ element with the W-26/Re wire mesh tackwelded to the edge of a one-piece Mo-Re hot cap 


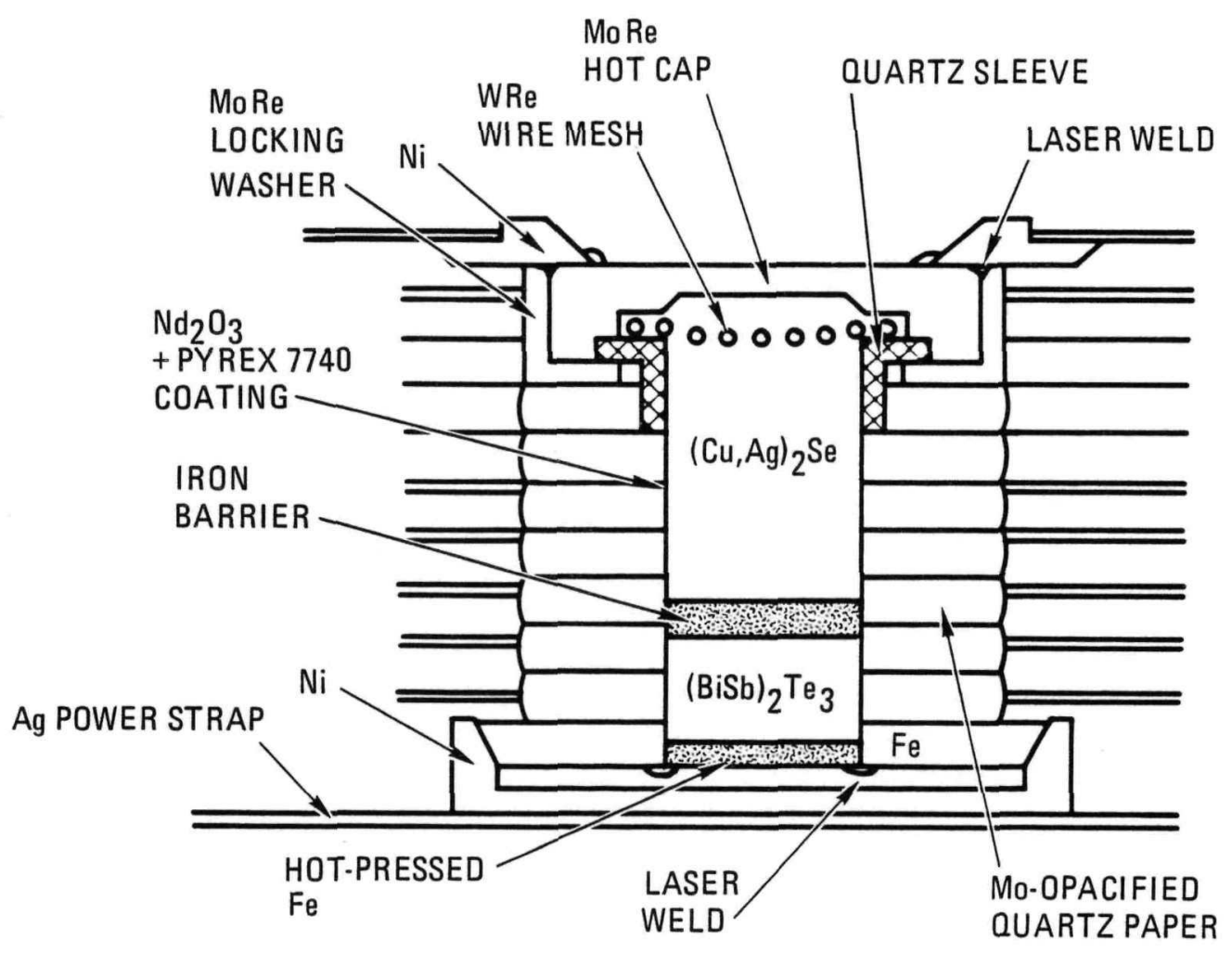

Fig. 2-14. Schematic diagram of a segmented $P$ element with $W$-26/Re wire mesh tack-welded to the edge of a two-piece rhenium hot cap 


\subsection{EVALUATION OF SEGMENTED P-TYPE ELEMENTS}

\subsubsection{Isothermal Testing}

Table 2-3 summarizes the results of measurements of Seebeck coefficients before and after isothermal compatibility tests of different doubly segmented elements. Microprobe examination of specimen 6875-102-1, Fig. 2-15, and other probe examinations show the following:

1. The sharp boundary between $(\mathrm{Cu}, \mathrm{Ag})_{2} \mathrm{Se}$ and $\mathrm{PbSnMnTe}-3 \mathrm{P}$ no longer exists. In its place are two new phases between these segments.

2. A PbSnMnSe phase has formed in the selenide segment boundary.

3. $\mathrm{A}(\mathrm{Cu}, \mathrm{Ag})_{2} \mathrm{Te}$ phase has formed in the telluride segment boundary.

In spite of the phase formations, the Seebeck coefficients for the total element show a slight increase after $400 \mathrm{~h}$ at $470^{\circ} \mathrm{C}$. The slight decrease in Seebeck coefficients after $1470 \mathrm{~h}$ clearly indicates that more testing is needed before definitive answers can be obtained about the stability of the $(\mathrm{Cu}, \mathrm{Ag})_{2} \mathrm{Se} / \mathrm{PbSnMnTe}$ segment combination.

The $275^{\circ} \mathrm{C}, 748$-h, isothermal tests of the $(\mathrm{Cu}, \mathrm{Ag})_{2} \mathrm{Se} /(\mathrm{Bi}, \mathrm{Sb})_{2} \mathrm{Te}_{3}$ segmented element show no time-dependent degradation mechanism for the $(\mathrm{Bi}, \mathrm{Sb})_{2} \mathrm{Te}_{3}$ segment. The overall Seebeck coefficients for these early specimens were so low to begin with that the $(\mathrm{Bi}, \mathrm{Sb})_{2} \mathrm{Te}_{3}$ segment was probably saturated with copper during element fabrication.

\subsubsection{Zero-Current Thermal Gradient Testing}

The objectives of zero-current thermal gradient tests were to (1) compare bonded segmented elements with unbonded but stacked segments, (2) compare segmented elements hot pressed sequentially in two different dies with those hot pressed in the same die, and (3) identify chemical potential influences on element stability.

2.2.2.1. $\quad(\mathrm{Cu}, \mathrm{Ag})_{2} \mathrm{Se}$ and $(\mathrm{Bi}, \mathrm{Sb})_{2} \mathrm{Te}_{3}$ Segments Hot Pressed in the Same Die. Two elements, 6875-132-12 and 6875-132-35, with $(\mathrm{Cu}, \mathrm{Ag})_{2} \mathrm{Se}$ and $(\mathrm{Bi}, \mathrm{Sb})_{2} \mathrm{Te}_{3}$ segments fabricated in the same die were tested in a thermal gradient. Sample 6875-132-35 had an ionplated molybdenum coating on the bottom of the stainless-steel cap to inhibit elements from the cap from diffusing through the $(\mathrm{Cu}, \mathrm{Ag})_{2} \mathrm{Se}$ and accumulating at the iron barrier. Sample 6875-132-12 contained no molybdenum barrier coating. These elements were sequentially hot pressed as follows:

1. The $(\mathrm{Cu}, \mathrm{Ag})_{2}$ Se plus iron segment was hot pressed at $600^{\circ} \mathrm{C}$ and $138 \mathrm{MPa}(20,000$ psi), then postannealed at $800^{\circ} \mathrm{C}$ for $1 \mathrm{~h}$. Stainless-steel hot caps with molybdenum wire mesh were used.

2. The hot pressed $(\mathrm{Cu}, \mathrm{Ag})_{2} \mathrm{Se} / \mathrm{Fe}$ segment was removed from the die, and the end was squared off to make a sharp, uniform $\mathrm{Fe} /(\mathrm{Bi}, \mathrm{Sb})_{2} \mathrm{Te}_{3}$ interface.

3. The $(\mathrm{Cu}, \mathrm{Ag})_{2} \mathrm{Se} / \mathrm{Fe}$ segment was reinstalled in the die, $(\mathrm{Bi}, \mathrm{Sb})_{2} \mathrm{Te}_{3}$ powder was added, and the second hot pressing was made at $450^{\circ} \mathrm{C}$ and $138 \mathrm{MPa}(20,000$ psi) in vacuo. 
TABLE 2-3

SEGMENTED P-ELEMENT ISOTHERMAL COMPATIBILITY

TEST SUMMARY, STABILITY OF SEEBECK COEFFICIENTS

\begin{tabular}{|c|c|c|c|c|c|c|c|}
\hline \multirow[b]{2}{*}{$\begin{array}{l}\text { Specimen } \\
\text { No. }\end{array}$} & \multirow[b]{2}{*}{ Upper Segment } & \multirow[b]{2}{*}{ Barrier } & \multirow[b]{2}{*}{ Lower Segment } & \multirow{2}{*}{$\begin{array}{c}\text { Test } \\
\text { Temperature } \\
\left({ }^{\circ} \mathbf{C}\right)\end{array}$} & \multirow{2}{*}{$\begin{array}{l}\text { Total } \\
\text { Test } \\
\text { (h) }\end{array}$} & \multicolumn{2}{|c|}{$\begin{array}{c}\text { Seebeck } \\
\text { Coefficient, } \alpha \\
\left(\mu \mathrm{V} /{ }^{\circ} \mathbf{C}\right)\end{array}$} \\
\hline & & & & & & Start & $\begin{array}{l}\text { End } \\
\text { of Test }\end{array}$ \\
\hline $6875-85-2$ & $(\mathrm{Cu}, \mathrm{Ag})_{2} \mathrm{Se}$ & Iron & PbSnMnTe-3P & 470 & 330 & 162 & 153 \\
\hline $6875-85-4$ & $(\mathrm{Cu}, \mathrm{Ag})_{2} \mathrm{Se}$ & Iron & PbSnMnTe-3P & 470 & 145 & 159 & 146 \\
\hline $6875-85-1$ & $(\mathrm{Cu}, \mathrm{Ag})_{2} \mathrm{Se}$ & Iron & PbSnMnTe-3P & 470 & 628 & 166 & 154 \\
\hline $6875-85-3$ & $(\mathrm{Cu}, \mathrm{Ag})_{2} \mathrm{Se}$ & Iron & PbSnMnTe-3P & 470 & 318 & 155 & 154 \\
\hline $6875-102-1$ & $(\mathrm{Cu}, \mathrm{Ag})_{2} \mathrm{Se}$ & None & PbSnMnTe-3P & 470 & 400 & 118 & 142 \\
\hline $6875-102-2$ & $(\mathrm{Cu}, \mathrm{Ag})_{2} \mathrm{Se}$ & None & PbSnMnTe-3P & 470 & 662 & 110 & 132 \\
\hline $6875-102-3$ & $(\mathrm{Cu}, \mathrm{Ag})_{2} \mathrm{Se}$ & Iron & PbSnMnTe-3P & 470 & 304 & 167 & 155 \\
\hline $6875-102-4$ & $(\mathrm{Cu}, \mathrm{Ag})_{2} \mathrm{Se}$ & Iron & PbSnMnTe-3P & 470 & 304 & 171 & 161 \\
\hline $6875-102-2$ & $(\mathrm{Cu}, \mathrm{Ag})_{2} \mathrm{Se}$ & None & PbSnMnTe-3P & 465 & 1407 & 110 & 90 \\
\hline $6875-110-11$ & $(\mathrm{Cu}, \mathrm{Ag})_{2} \mathrm{Se}$ & Hot-side graded zone/Iron & $\mathrm{PbSnMnTe}-3 \mathrm{P}$ & 465 & 745 & 213 & 201 \\
\hline $6875-110-16$ & $(\mathrm{Cu}, \mathrm{Ag})_{2} \mathrm{Se}$ & $\begin{array}{l}\text { Hot-side graded zone/Iron/ } \\
\text { Cold-side graded zone }\end{array}$ & PbSnMnTe-3P & 465 & 745 & 210 & 202 \\
\hline $6875-112-31$ & $(\mathrm{Cu}, \mathrm{Ag})_{2} \mathrm{Se}+5 \% \mathrm{Nd}_{2} \mathrm{O}_{3}$ & None & $\mathrm{PbSnMnTe}-3 \mathrm{P}$ & 465 & 745 & 73 & 57 \\
\hline $6875-112-36$ & $(\mathrm{Cu}, \mathrm{Ag})_{2} \mathrm{Se}+5 \% \mathrm{Pr}_{2} \mathrm{O}_{3}$ & None & $\mathrm{PbSnMnTe-3P}$ & 465 & 745 & 92 & 56 \\
\hline $6875-112-11$ & $(\mathrm{Cu}, \mathrm{Ag})_{2} \mathrm{Se}+5 \% \mathrm{Mo}$ & None & PbSnMnTe-3P & 465 & 745 & 58 & 55 \\
\hline 6875-110-36 & $(\mathrm{Cu}, \mathrm{Ag})_{2} \mathrm{Se}$ & None & $(\mathrm{Bi}, \mathrm{Sb})_{2} \mathrm{Te}_{3}$ & 275 & 748 & 61 & 61 \\
\hline $6875-118-8$ & $(\mathrm{Cu}, \mathrm{Ag})_{2} \mathrm{Se}$ & None & $(\mathrm{Bi}, \mathrm{Sb})_{2} \mathrm{Te}_{3}$ & 275 & 748 & 57 & 58 \\
\hline $6875-118-11$ & $(\mathrm{Cu}, \mathrm{Ag})_{2} \mathrm{Se}$ & None & $(\mathrm{Bi}, \mathrm{Sb})_{2} \mathrm{Te}_{3}$ & 275 & 748 & 63 & 61 \\
\hline $6875-118-12$ & $(\mathrm{Cu}, \mathrm{Ag})_{2} \mathrm{Se}$ & $\begin{array}{l}\text { Hot-side graded zone/Iron/ } \\
\text { Cold-side graded zone }\end{array}$ & $(\mathrm{Bi}, \mathrm{Sb})_{2} \mathrm{Te}_{3}$ & 275 & 748 & 198 & 198 \\
\hline
\end{tabular}




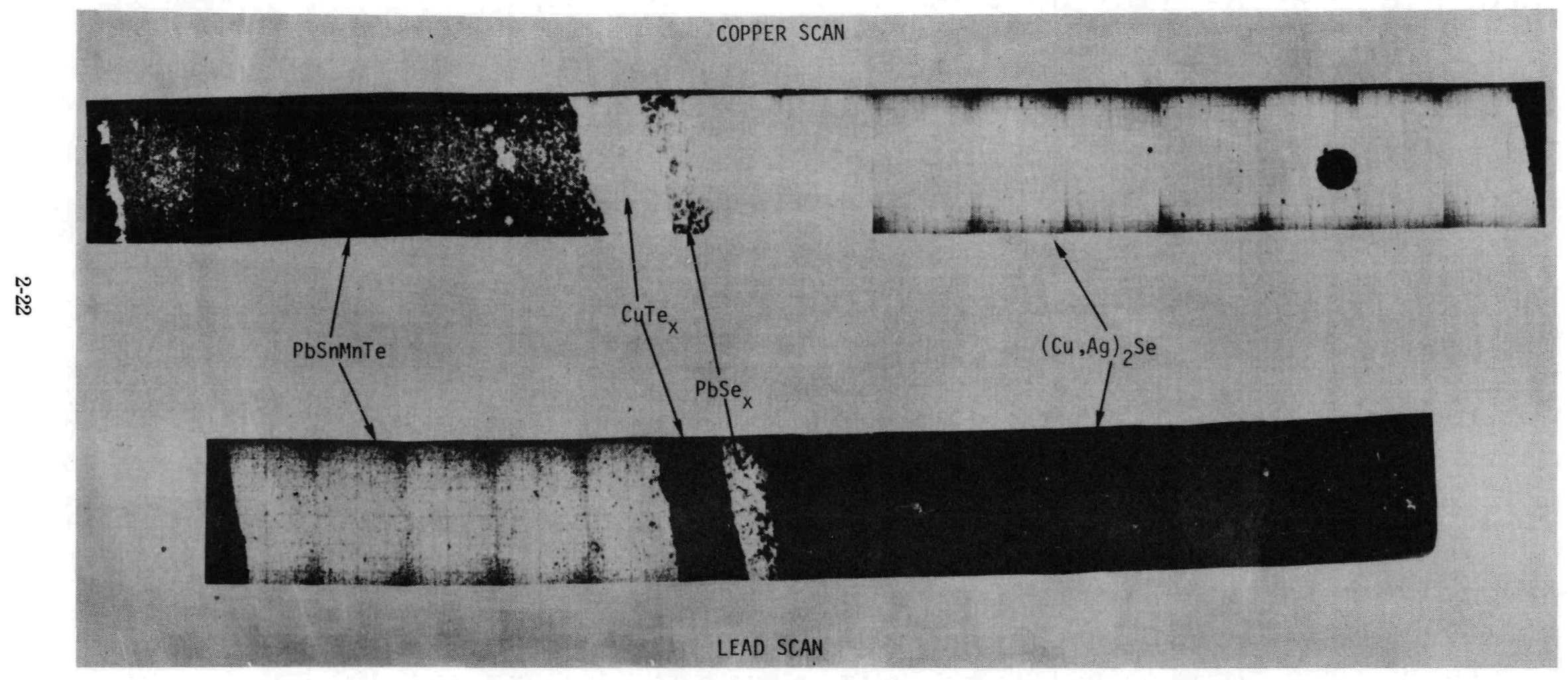

Fig. 2-15. Microprobe scan of double segmented P element specimen 6875-102-1 after a 400-h, $475^{\circ} \mathrm{C}$ isothermal heat treatment 
Cold caps were added to the elements, and thermocouples were attached for thermal gradient testing. Figure 2-16 shows sample 6875-132-12, removed from testing after 64 $\mathrm{h}$ at temperature. With no barrier between the stainless-steel cap and $(\mathrm{Cu}, \mathrm{Ag})_{2} \mathrm{Se}$, the cap elements transported and accumulated above the iron barrier (note the metal collar around the middle of the sample). Figures 2-17 and 2-18 show the data for the first 350 test hours of sample $6875-132-35$. The $(\mathrm{Bi}, \mathrm{Sb})_{2} \mathrm{Te}_{3}$ segment was evidently contaminated with copper during hot pressing, and its thermoelectric properties did not change significantly after that. Thermocouples were tack-welded to the iron barrier between the $(\mathrm{Cu}, \mathrm{Ag})_{2} \mathrm{Se}$ and $(\mathrm{Bi}, \mathrm{Sb})_{2} \mathrm{Te}_{3}$ segments of sample 6875-132-35. This allowed each segment and the overall element performance to be monitored. The middle thermocouple was lost as were the data on the lower segment. Figures 2-19 and 2-20 show the overall stability of the Seebeck coefficient and resistivity of segmented element 6875-132-35. The result shows only small changes in the thermoelectric properties during the hot-cap temperature $\left(\mathrm{T}_{\mathrm{H}}\right)=754^{\circ} \mathrm{C} \pm 5^{\circ} \mathrm{C}$ and cold-cap temperature $\left(\mathrm{T}_{\mathrm{C}}\right)=107^{\circ} \mathrm{C} \pm 8^{\circ} \mathrm{C}, 2490$-h test. These early test samples were originally intended to evaluate the fabrication process and thus had no vapor suppression coating or sleeves. They were, therefore, expected to show copper movement and accelerated degradation. This was not the case. Without current flow, the segmented $(\mathrm{Cu}, \mathrm{Ag})_{2} \mathrm{Se} / \mathrm{Fe} /(\mathrm{Bi}, \mathrm{Sb})_{2} \mathrm{Te}_{3}$ element was reasonably stable. The overall stability of the thermoelectric properties of the element keeps it on test longer than was originally intended. Post-test examinations showed significantly fewer changes in the appearance of the $(\mathrm{Cu}, \mathrm{Ag})_{2} \mathrm{Se}$ segment than those described in the similarily tested unbonded $\mathrm{P}$ element without a barrier coating on the hot cap. The molybdenum cap barrier, however, was breached, and corrosion at this interface had begun.

The movement of copper was stopped at the iron barrier. The $(\mathrm{Cu}, \mathrm{Ag})_{2} \mathrm{Se} / \mathrm{Fe}$ joint did not degrade, and copper did not tend to transport through or around the iron barrier. The rather modest changes in Seebeck coefficient and resistivity did not reflect the appearance changes in the molybdenum mesh or the $(\mathrm{Cu}, \mathrm{Ag})_{2} \mathrm{Se}$ segment. Microprobe examinations, schematically summarized in Fig. 2-21, show a $\mathrm{Mo}_{\mathrm{x}} \mathrm{Cu}_{\mathrm{y}} \mathrm{Se}$ compound formed around the molybdenum wire. This reactivity of the $(\mathrm{Cu}, \mathrm{Ag})_{2} \mathrm{Se}$ with molybdenum is thought to be catalyzed by nickel or chromium coming from the hot cap. In previous compatibility tests between slabs of $(\mathrm{Cu}, \mathrm{Ag})_{2} \mathrm{Se}$ and molybdenum without stainless steel, microprobes did not observe that any reaction occurred between these materials even when held in contact at $900^{\circ} \mathrm{C}$. The occurrence of the nickel, chromium, and iron in islands above the segment interface shows that the molybdenum-coated 316 stainless steel did not prevent nickel, chromium, and iron from diffusing in this test.

2.2.2.2. $\quad(\mathrm{Cu}, \mathrm{Ag})_{2} \mathrm{Se}$ and $(\mathrm{Bi}, \mathrm{Sb})_{2} \mathrm{Te}_{3}$ Segments Hot Pressed in Different Dies. A third doubly segmented P element, 6875-141-1, was thermal gradient tested with zerocurrent flow. The element composition was identical to 6875-132-35; the elements differed in the processing sequence. Element 6875-141-1 was hot pressed with two different dies, one for each segment, to avoid copper contamination of the $(\mathrm{Bi}, \mathrm{Sb})_{2} \mathrm{Te}_{3}$ segment.

Figures 2-22 and 2-23 show zero-current, life-test, Seebeck coefficient and resistivity values for this element. The thermal gradient across the $(\mathrm{Cu}, \mathrm{Ag})_{2} \mathrm{Se}$ segment was $\mathrm{T}_{\mathrm{H}}$ $=752^{\circ} \mathrm{C} \pm 10^{\circ} \mathrm{C}$ and $\mathrm{T}_{\mathrm{C}}=190^{\circ} \mathrm{C}+5^{\circ} \mathrm{C}$. The thermal gradient across the $\left(\mathrm{Bi}, \mathrm{Sb}_{2} \mathrm{Te}_{3}\right.$ segment was $\mathrm{T}_{\mathrm{H}}=190^{\circ} \mathrm{C} \pm 5^{\circ} \mathrm{C}$ and $\mathrm{T}_{\mathrm{C}}=47^{\circ} \mathrm{C} \pm 5^{\circ} \mathrm{C}$. After 1100 test hours, Seebeck coefficient and resistivity values began to change radically. The element was removed 


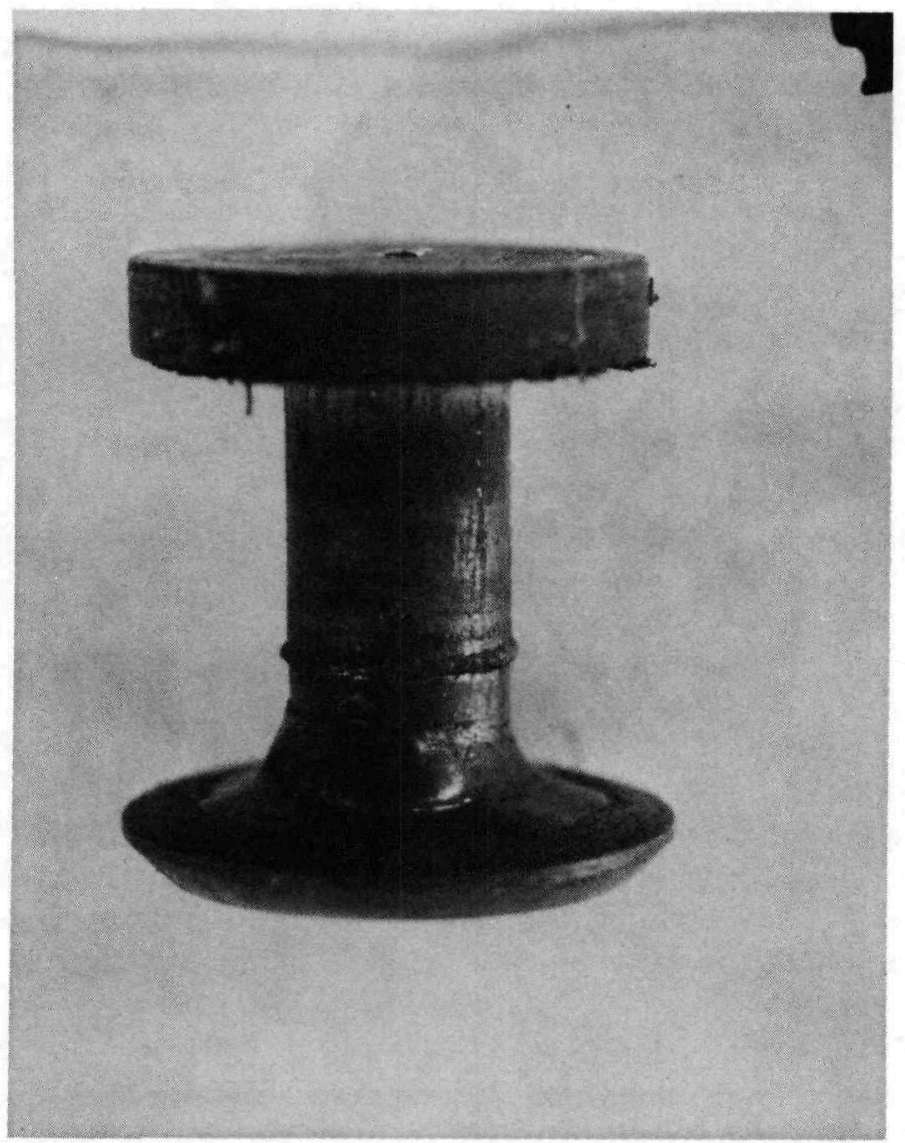

Fig. 2-16. Macrophoto of doubly segmented P-type element 6875-132-12 after 64 h in a $T_{11}=$ $755^{\circ} \mathrm{C}, T_{\mathrm{C}}=133^{\circ} \mathrm{C}$ zero-current thermal gradient test 


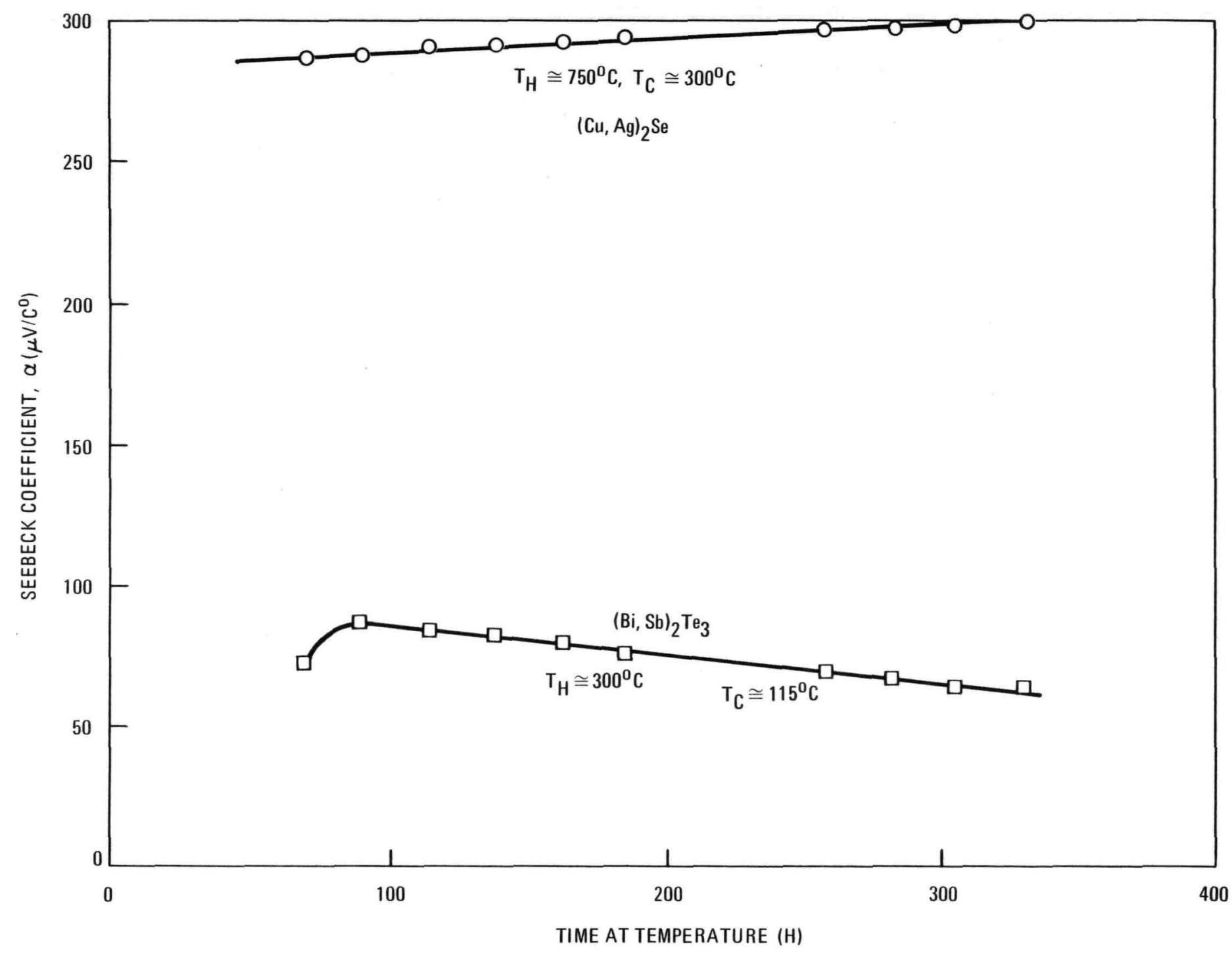

Fig. 2-17. Seebeck coefficients of segmented P-type element 6875-132-35 during zero-current thermal gradient compatibility testing 


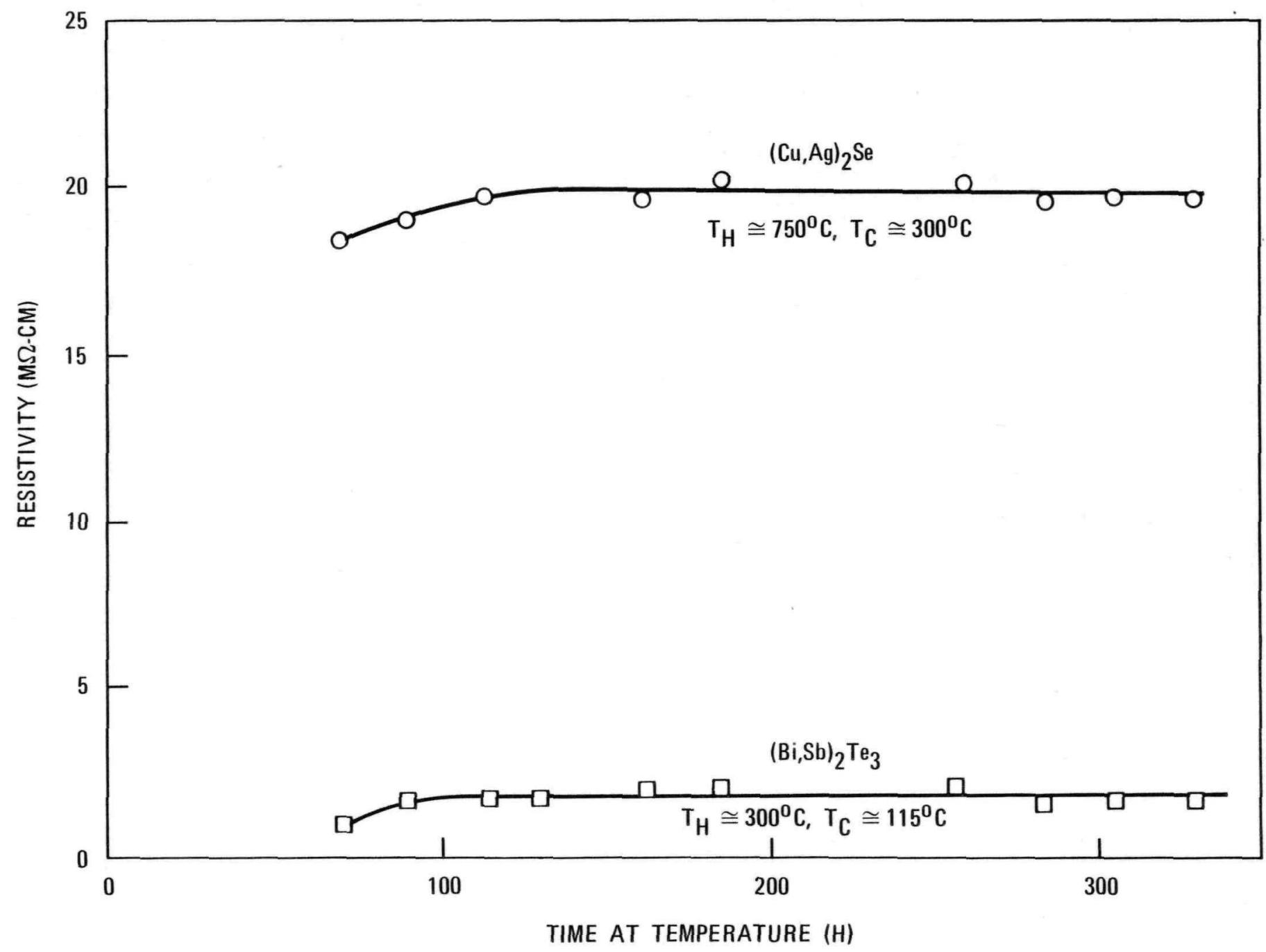

Fig. 2-18. Resistivity values of segmented P-type element 6875-132-35 during zero-current thermal gradient compatibility testing 


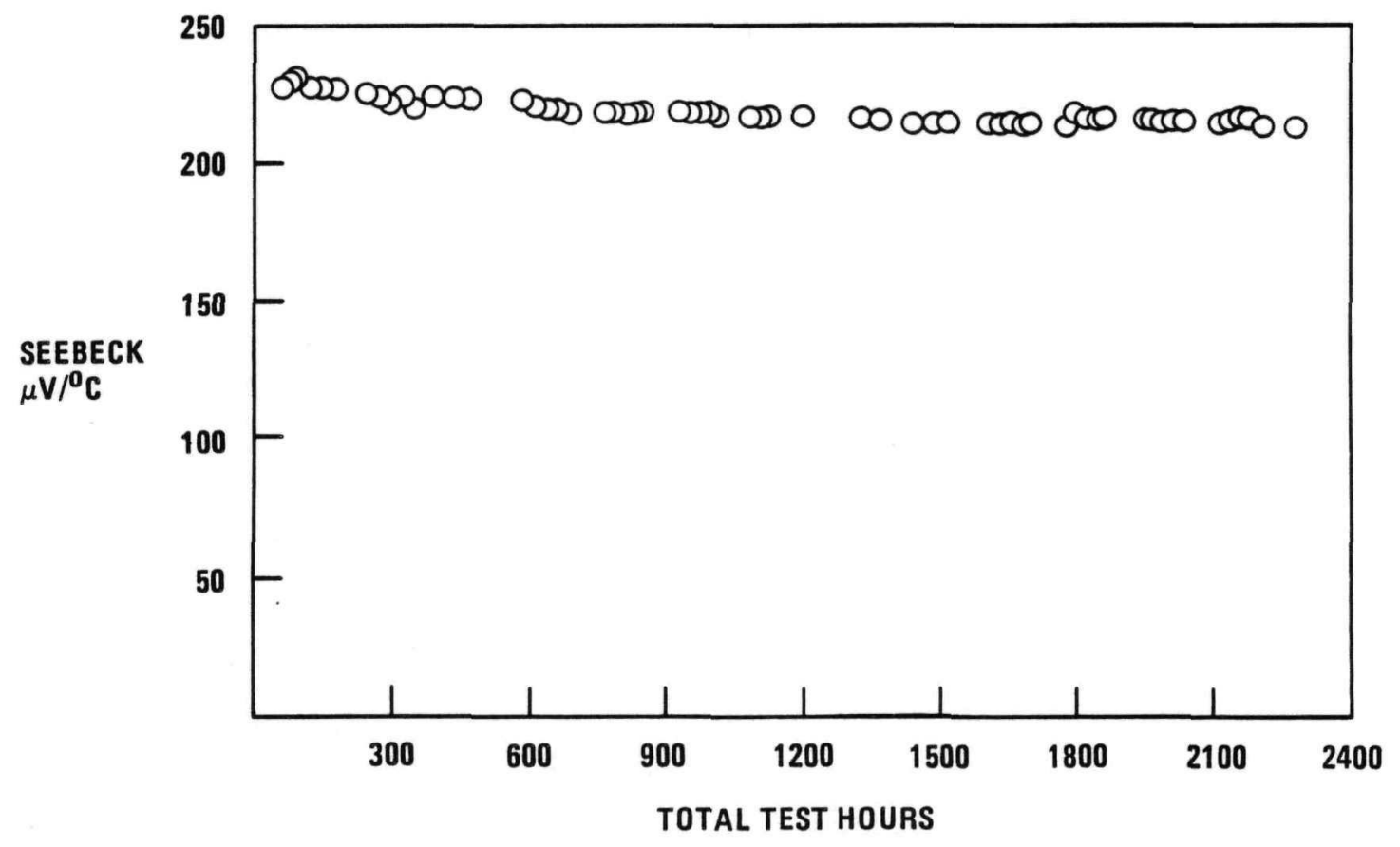

Fig. 2-19. Seebeck coefficients of P-type element 6875-132-35 containing $(\mathrm{Cu}, \mathrm{Ag}) . \mathrm{Se} / \mathrm{Fe} /(\mathrm{Bi}$, $\mathrm{Sb}$.. $\mathrm{Te}$ :; segments sequentially hot-pressed zero-current, $754^{\circ} \mathrm{C} / 107^{\circ} \mathrm{C}$, thermal gradient testing 


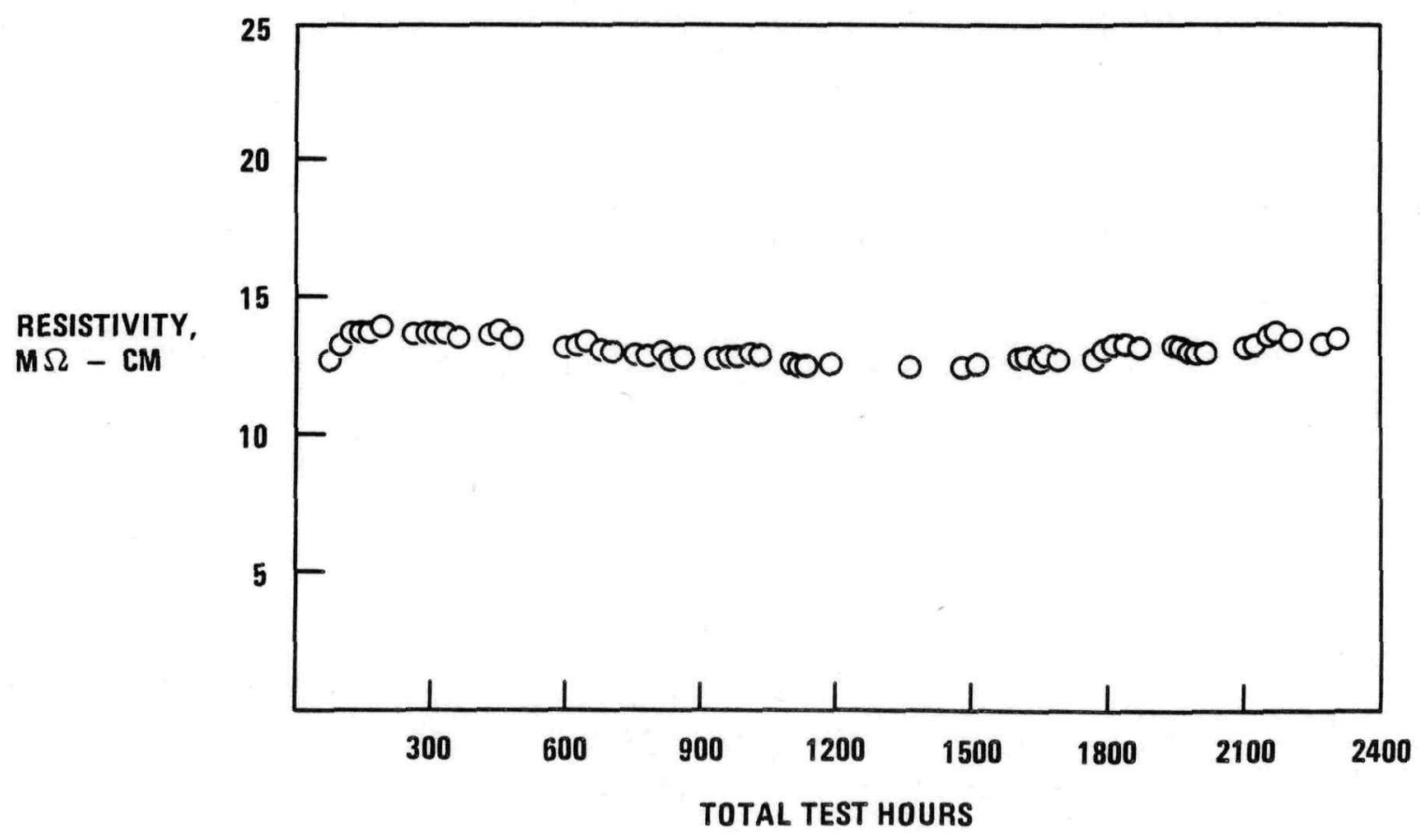

Fig. 2-20. Resistivity values of P-type element 6875-132-35 containing $(\mathrm{Cu}, \mathrm{Ag})_{2.2} \mathrm{Se} / \mathrm{Fe} /(\mathrm{Bi}, \mathrm{Sb})_{\text {.- }}$ $\mathrm{Te}_{: ;}$segments sequentially hot-pressed zero-current, $754^{\circ} \mathrm{C} / 107^{\circ} \mathrm{C}$, thermal gradient testing 


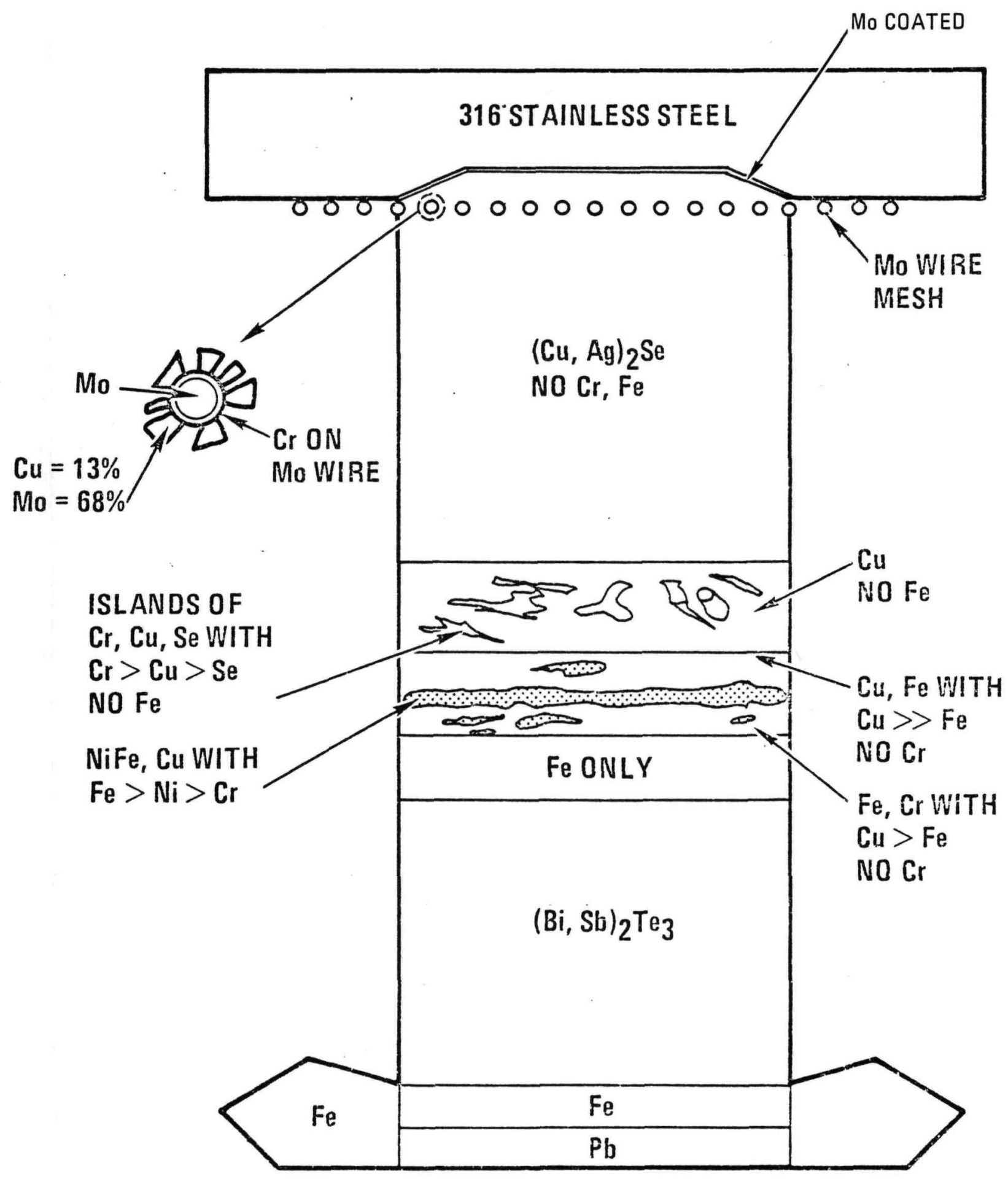

Fig. 2-21. Microprobe examination of doubly segmented $P$ element 6875-132-35 after 2490 $h$ in a $754^{\circ} \mathrm{C} / 107^{\circ} \mathrm{C}$ thermal gradient 


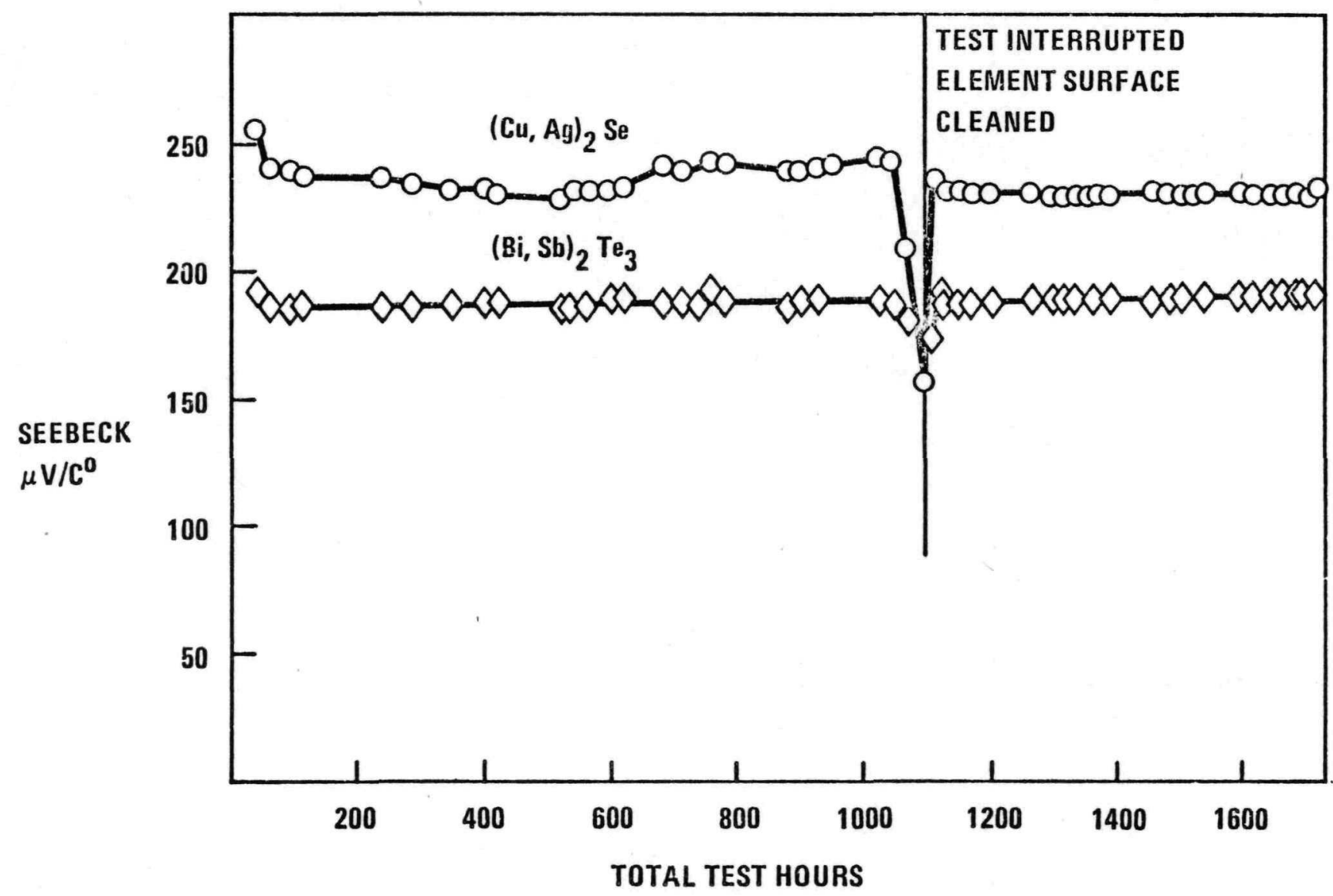

Fig. 2-22. Seebeck coefficients of P-type element 6875-141 containing $(\mathrm{Cu}, \mathrm{Ag}) ., \mathrm{Se} / \mathrm{Fe} /(\mathrm{Bi}, \mathrm{Sb})$.

Te.: segments sequentially hot pressed in separate dies during zero-current, $752^{\circ} \mathrm{C} /$ $190^{\circ} \mathrm{C} / 47^{\circ} \mathrm{C}$, thermal gradient testing 


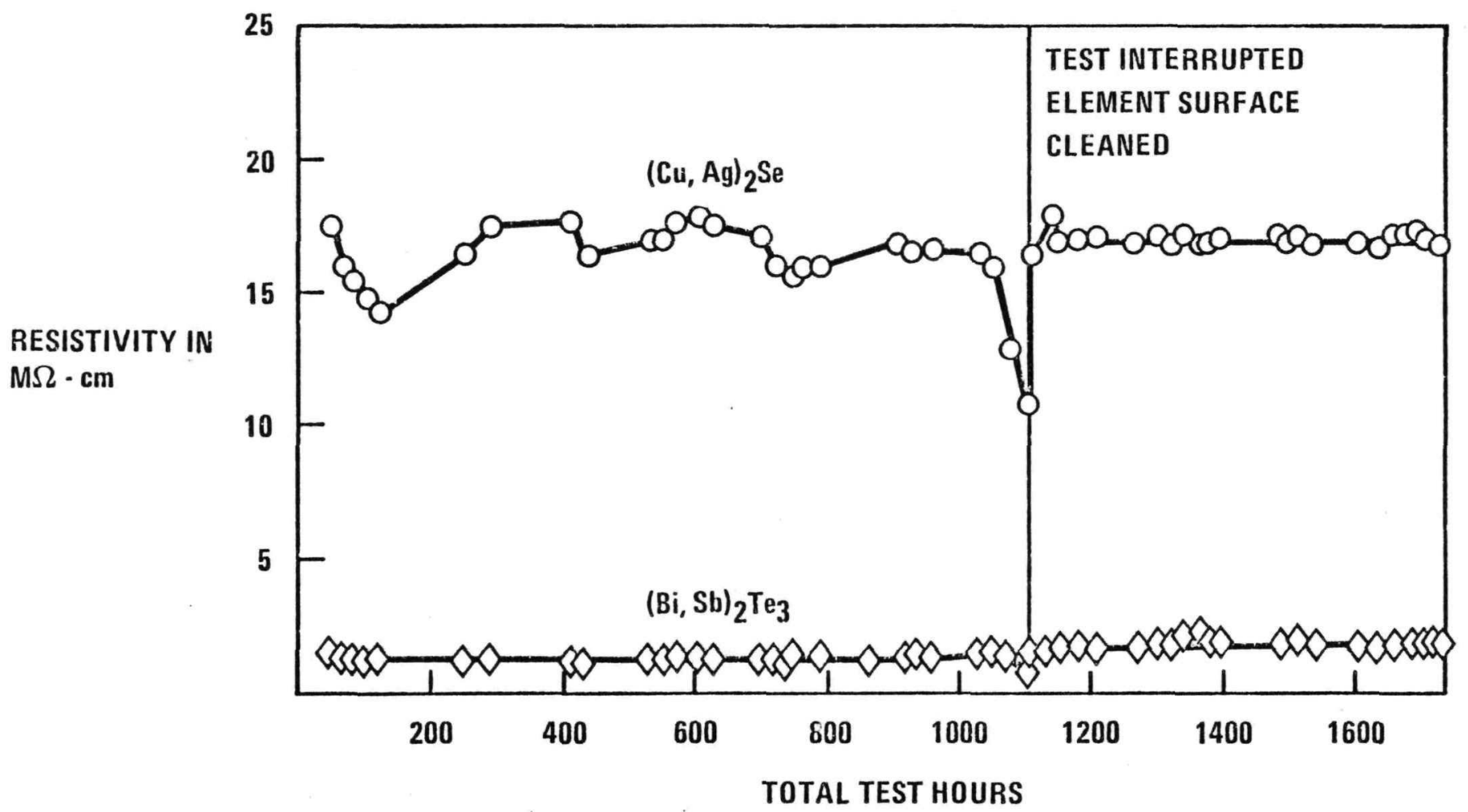

Fig. 2-23. Resistivity values of P-type element 6875-141 containing (Cu, $\mathrm{A}(y)$., $\mathrm{Se} / \mathrm{Fe} /(\mathrm{Bi}, \mathrm{Sb})$., Te:; segments sequentially hot pressed in separate dies during zero-current, $752^{\circ} \mathrm{C} /$ $190^{\circ} \mathrm{C} / 47^{\circ} \mathrm{C}$, thermal gradient testing 
from test and examined. A vapor-deposited copper coating could be seen over most of the element (Fig. 2-24). A bulge was also noted above the iron barrier. The copper coating was due to vaporization of a copper shim placed between the hot cap and specimen heater to maximize heat transfer to the hot cap. The copper coating was grit-blast-removed, electrodes and thermocouples were reattached to the element, and the element was remounted in the test stand. Seebeck coefficient and resistivity values after reheating show that the apparent element degradation was an artifact due to the vapor-deposited copper coating. Encouragingly, the $(\mathrm{Bi}, \mathrm{Sb})_{2} \mathrm{Te}_{3}$ segment did not degrade when in direct contact with copper on its surface. The operating temperatures of the $(\mathrm{Bi}, \mathrm{Sb})_{2} \mathrm{Te}_{3}$ segment were apparently low enough to make the reaction between $(\mathrm{Bi}, \mathrm{Sb})_{2} \mathrm{Te}_{3}$ and copper very sluggish. Seebeck coefficient and resistivity values of this element were stable after the 1100 -h test interruption. No degradation of the $(\mathrm{Bi}, \mathrm{Sb})_{2} \mathrm{Te}_{3}$ segment from copper contamination is evident.

The sample was removed from the thermal gradient test after $2717 \mathrm{~h}$. Metallographic examination of this sample was essentially the same as 6875-132-35. The sample interacted corrosively with the hot cap. The molybdenum wire mesh was still encapsulated in the $(\mathrm{Cu}, \mathrm{Ag})_{2} \mathrm{Se}$ with the same formation of a $\mathrm{MoCrCu}$ compound in an intermediate layer between the wire and P-type element. Chromium, copper, nickel, and iron diffused as on all the stainless-steel hot cap samples tested. No copper bypassed the barrier. This was verified by the stable Seebeck coefficient of the $(\mathrm{Bi}, \mathrm{Sb})_{2} \mathrm{Te}_{3}$ layer. This test showed that the $(\mathrm{Bi}, \mathrm{Sb})_{2} \mathrm{Te}_{3}$ layer in sample $6875-132-35$ was degraded because the same die was used to hot press both segments. As long as separate dies are used, contamination of the $(\mathrm{Bi}, \mathrm{Sb})_{2} \mathrm{Te}_{3}$ with copper can be prevented.

2.2.2.3. (Cu,Ag $)_{2} \mathrm{Se}$ and $(\mathrm{Bi}, \mathrm{Sb})_{2} \mathrm{Te}_{3}$ Segments Behavior in Contact but Unbonded. A fourth zero-current thermal gradient test (6875-139-3) was conducted containing $(\mathrm{Cu}, \mathrm{Ag})_{2} \mathrm{Se} / \mathrm{Fe}$ and $(\mathrm{Bi}, \mathrm{Sb})_{2} \mathrm{Te}_{3} / \mathrm{Fe}$ segments. The $(\mathrm{Cu}, \mathrm{Ag})_{2} \mathrm{Se} / \mathrm{Fe}$ segment was bonded to a hot cap through a mesh bond. The $(\mathrm{Bi}, \mathrm{Sb})_{2} \mathrm{Te}_{3} / \mathrm{Fe}$ was soldered to a cold cap on the iron side of the segment. Thermocouples were attached to the hot cap, the cold cap, and the iron of the $(\mathrm{Cu}, \mathrm{Ag})_{2} \mathrm{Se}$ segment. The thermal gradient across the $(\mathrm{Cu}, \mathrm{Ag})_{2}$ Se segment was $\mathrm{T}_{\mathrm{H}}=752^{\circ} \mathrm{C} \pm 4^{\circ} \mathrm{C}$ and $\mathrm{T}_{\mathrm{C}}=300^{\circ} \mathrm{C} \pm 22^{\circ} \mathrm{C}$. The thermal gradient across the $(\mathrm{Bi}, \mathrm{Sb})_{2} \mathrm{Te}_{3}$ segment was $\mathrm{T}_{\mathrm{H}}=300^{\circ} \mathrm{C} \pm 22^{\circ} \mathrm{C}$ and $\mathrm{T}_{\mathrm{C}}=118^{\circ} \mathrm{C} \pm 12^{\circ} \mathrm{C}$. Figures $2-25$ and 2-26 show Seebeck coefficients and resistivities as a function of test time for these segments. The sample was held in place by a weighted heater block which put a $2.5 \mathrm{MPa}$ (363 psi) load on the element.

The upper and lower segments of the element were still unbonded at the end of the 1492-h test. Two gross features were noticed from the sample after removal from the test: A prominent bulge developed in the $(\mathrm{Cu}, \mathrm{Ag})_{2} \mathrm{Se}$ segment above the iron layer, and the $(\mathrm{Cu}, \mathrm{Ag})_{2} \mathrm{Se}$ corrosively reacted with the stainless-steel hot cap. Metallographic examination of a cross section of this element (Fig. 2-27) shows a necked down zone above the bulge from microprobe examinations (Fig. 2-28). This was thought to result from metal transport down the thermal gradient in the $(\mathrm{Cu}, \mathrm{Ag})_{2} \mathrm{Se}$ segment. The stainless-steel cap was not protected against reaction with the $(\mathrm{Cu}, \mathrm{Ag})_{2} \mathrm{Se}$. The weighted hot cap continued to react with the $(\mathrm{Cu}, \mathrm{Ag})_{2} \mathrm{Se}$ segment. Material was continually transported down this segment to the iron barrier. This created the bulge and cut a hole through the hot cap. 

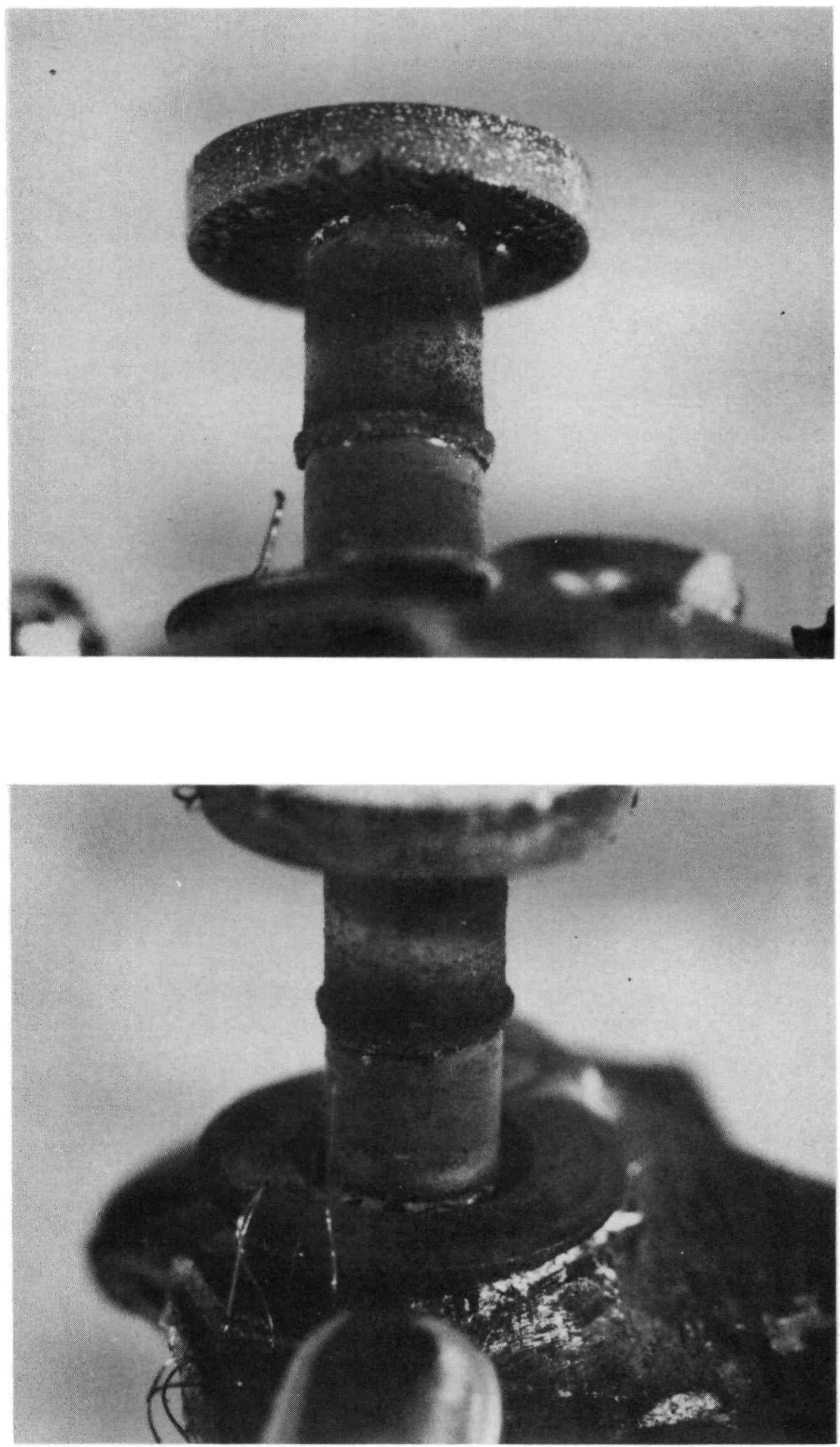

Fig. 2-24. Segmented P-type element 6875-141-1 removed from test after 1100 test hours for visual examination 


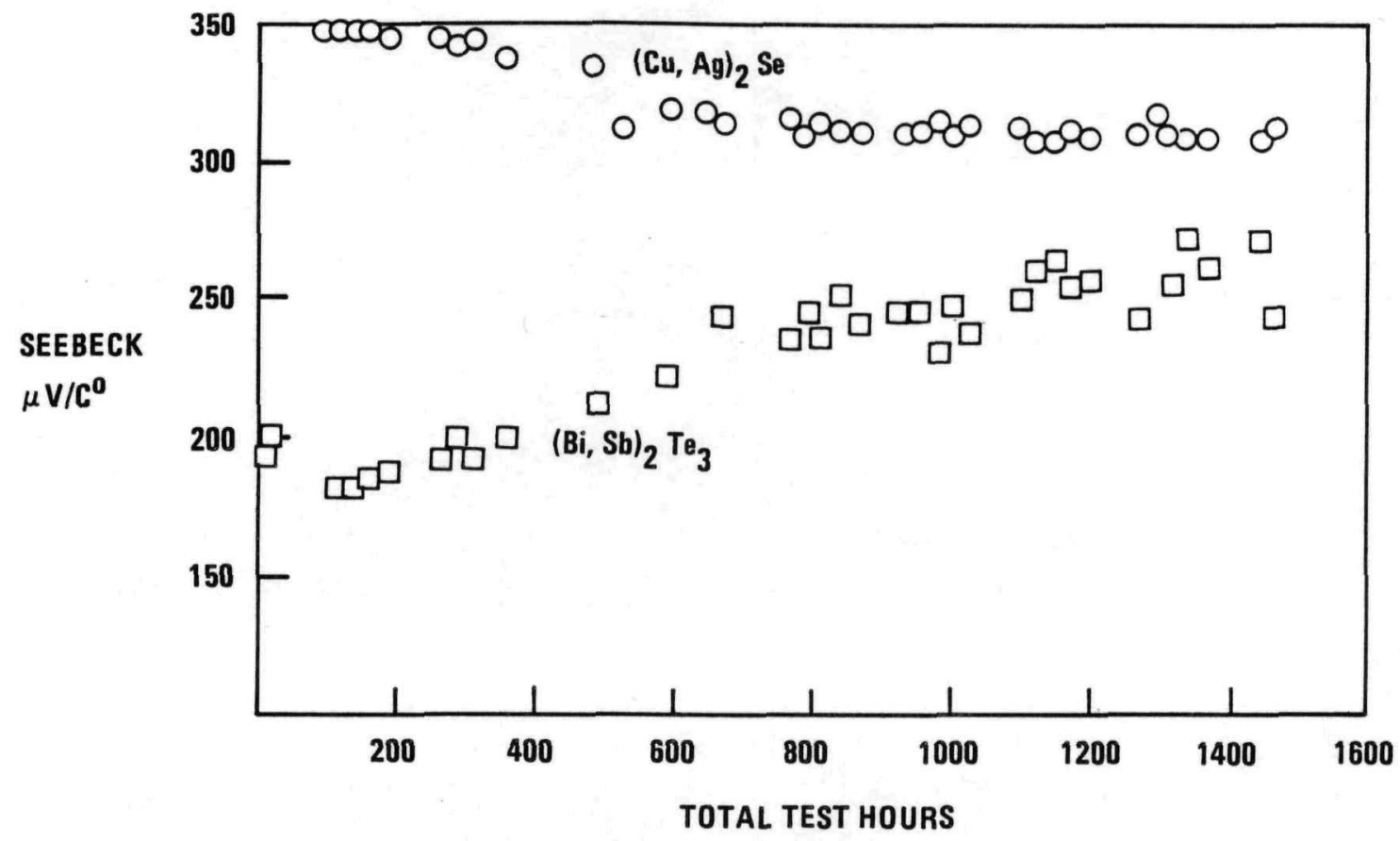

Fig. 2-25. Seebeck coefficients of $P$-type $(\mathrm{Cu}, \mathrm{Ag})_{2.2} \mathrm{Se} / \mathrm{Fe}$ and (Bi, Sb)., Te,; segments stacked unbonded and heated with $T_{\mathrm{HI}}=750^{\circ} \mathrm{C}, T_{\mathrm{C}}=300^{\circ} \mathrm{C}$, and $T_{\mathrm{II}}=300^{\circ} \mathrm{C}, T_{\mathrm{V}}=107^{\circ} \mathrm{C}$, respectively, in vacuo in zero-current test 6875-139-3 


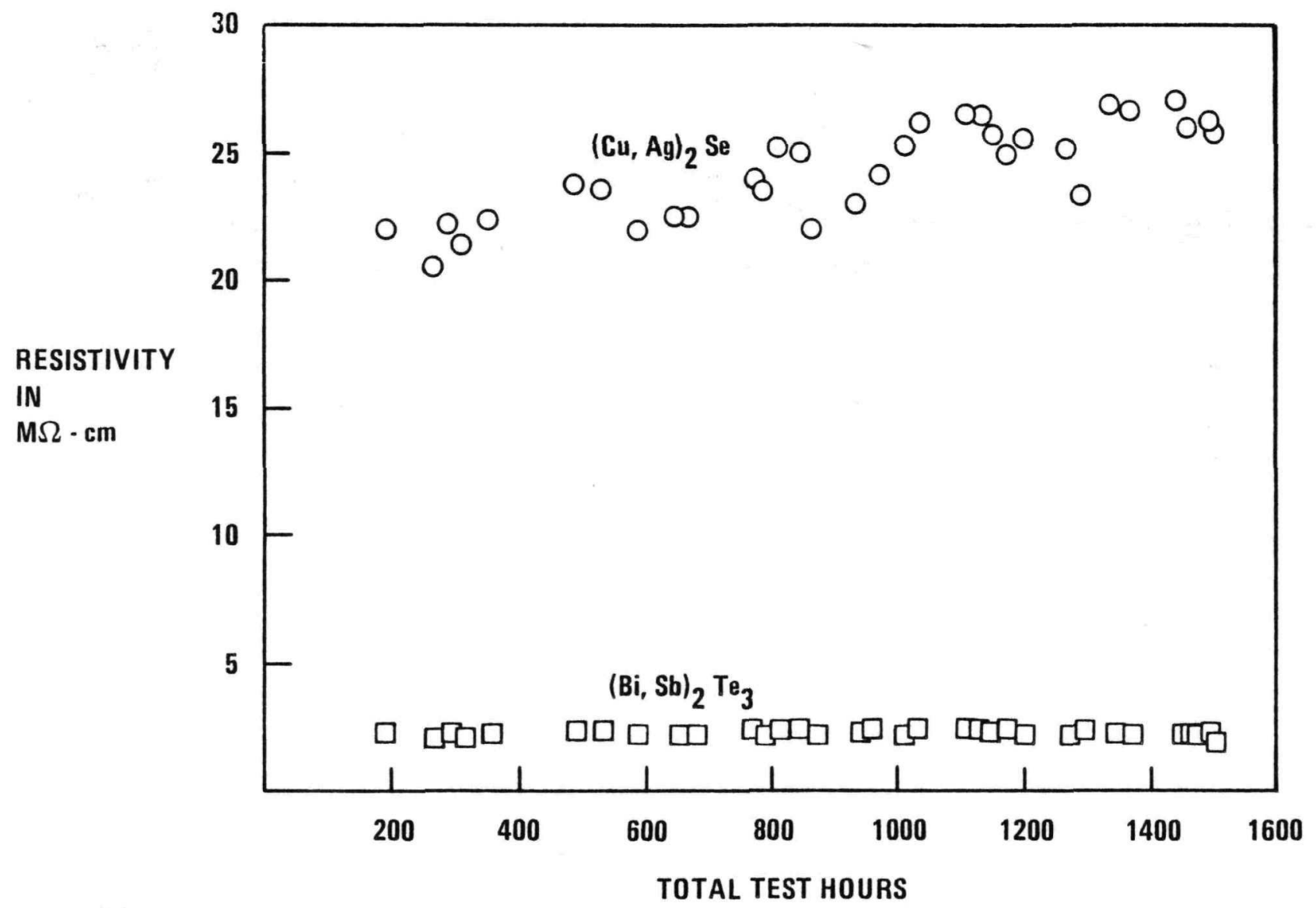

Fig. 2-26. Resistivity values of P-type $(\mathrm{Cu}, \mathrm{Ag})$., Se/Fe and (Bi, Sb)., Te, segments stacked unbonded and heated with $T_{11}=750^{\circ} \mathrm{C}, T_{\mathrm{C}^{\circ}}=300^{\circ} \mathrm{C}$, and $T_{11}=300^{\circ} \mathrm{C}, T_{1}{ }^{\circ}=107^{\circ} \mathrm{C}$ respectively, in vacuo in zero-current test 6875-139-3 


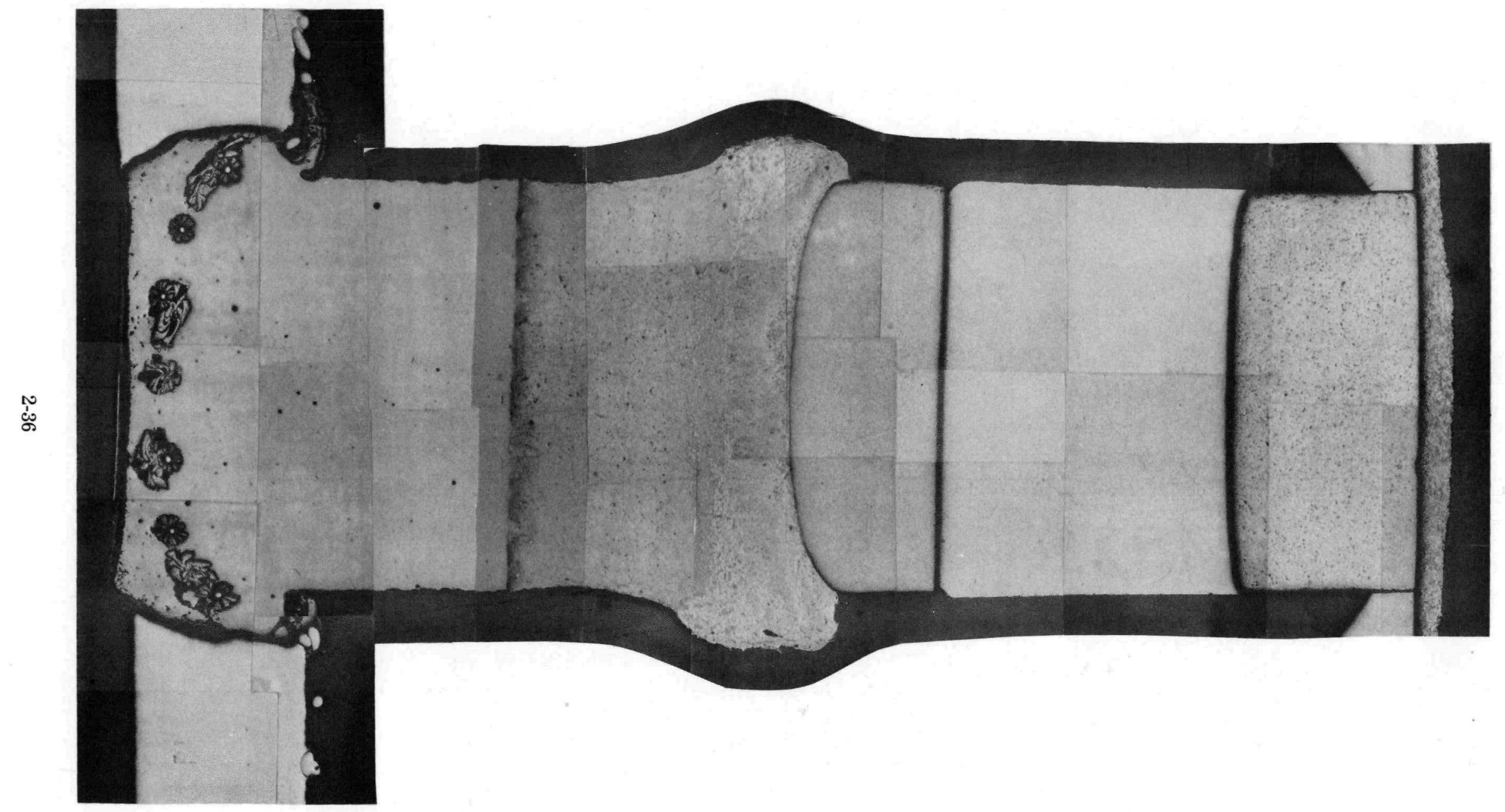

Fig. 2-27. Metallographic examination of a $1492-h, 300^{\circ} \mathrm{C}$ interface temperature, vacuo compatibility test of unbonded $(\mathrm{Cu}, \mathrm{Ag})_{2, \mathrm{~S} e}$ and $(\mathrm{Bi}, \mathrm{Sb})_{2} \mathrm{Te}_{3,3}$ segments separated from each other by an iron barrier in a thermal gradient of $754^{\circ} \mathrm{C} / 300^{\circ} \mathrm{C} / 118^{\circ} \mathrm{C}$. The

molybdenum mesh in the $(\mathrm{Cu}, \mathrm{Ag})_{2}$ Se shows attack apparently because of the presence of iron, nickel, or chromium from the 316 stainless steel cap. Under normal conditions, molybdenum exhibits no attack. 


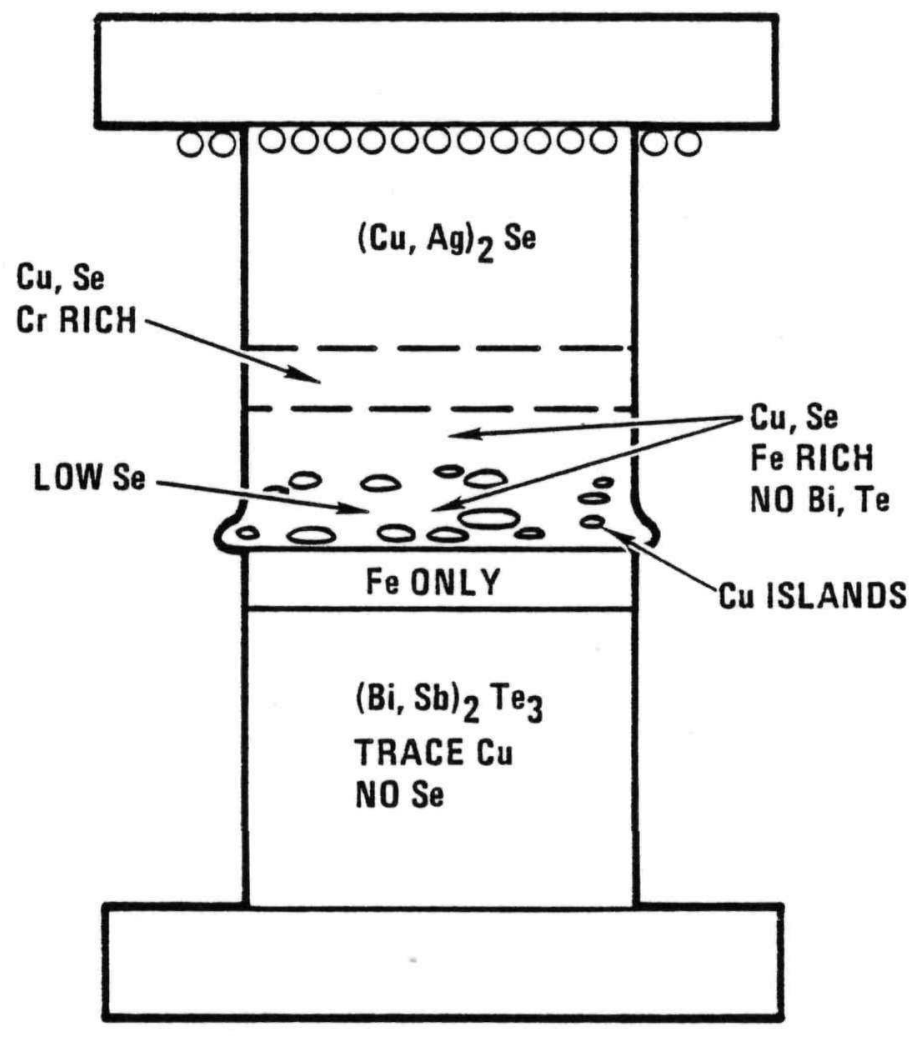

Fig. 2-28. Results of microprobe examinations of stacked unbonded segments of ( $\mathrm{Cu}, \mathrm{Ag}$ ).. $\mathrm{Se} / \mathrm{Fe}$ and $(\mathrm{Bi}, \mathrm{Sb})$. Te $e_{3,3}$ after $1492 \mathrm{~h}$ in a zero-current $754^{\circ} \mathrm{C} / 300^{\circ} \mathrm{C} / 118^{\circ} \mathrm{C}$ thermal gradient 
Important results of this test were

1. Copper and other elements from the stainless-steel cap transported down the thermal gradient and formed a bulge at the iron barrier interface. The bulge, however, did not bridge the iron barrier between the $(\mathrm{Cu}, \mathrm{Ag})_{2} \mathrm{Se}$ and $(\mathrm{Bi}, \mathrm{Sb})_{2} \mathrm{Te}_{3}$ segments.

2. The $(\mathrm{Bi}, \mathrm{Sb})_{2} \mathrm{Te}_{3}$ segment was unaffected by metal transport in $(\mathrm{Cu}, \mathrm{Ag})_{2} \mathrm{Se}$ when separated from it by a $0.05-\mathrm{cm}$ iron barrier in a $1492-\mathrm{h}, 300^{\circ} \mathrm{C}$ interface test.

3. The thermoelectric properties of $(\mathrm{Cu}, \mathrm{Ag})_{2} \mathrm{Se}$ show surprisingly little sensitivity to dissolved nickel, chromium, and iron.

4. Unbonded segments of $(\mathrm{Cu}, \mathrm{Ag})_{2} \mathrm{Se} / \mathrm{Fe}$ and $(\mathrm{Bi}, \mathrm{Sb})_{2} \mathrm{Te}_{3}$, when stacked, behaved similarly to segmented-but-bonded elements in thermal gradient tests. Thus, sequentially hot pressed elements are satisfactory if hot pressed in separate dies.

\subsubsection{Life Testing of $P$ Element with Current}

When an electrical potential is connected across a segmented P-type element and load, the stability of the segmented $(\mathrm{Cu}, \mathrm{Ag})_{2} \mathrm{Se}$ can change dramatically. One objective of the thermal gradient tests with current flow was to determine if $(\mathrm{Cu}, \mathrm{Ag})_{2} \mathrm{Se}$ would function stably with current flow. Another objective was to examine the behavior of $(\mathrm{Cu}, \mathrm{Ag})_{2} \mathrm{Se}$ in an operational mode to understand the degradation mechanisms operating.

2.2.3.1. Current Flow and (Cu,Ag) $)_{2}$ Se Resistivity. A segmented $(\mathrm{Cu}, \mathrm{Ag})_{2} \mathrm{Se} / \mathrm{Fe} /$ $(\mathrm{Bi}, \mathrm{Sb})_{2} \mathrm{Te}_{3} \mathrm{P}$ element $(6875-144-4)$ was operated with $\mathrm{T}_{\mathrm{H}}=757^{\circ} \mathrm{C}$ and $\mathrm{T}_{\mathrm{C}}=55^{\circ} \mathrm{C}$ for $307 \mathrm{~h}$. A current of $1.52 \mathrm{~A}$ was passed through the element; this corresponds to an iL/ A of 8. This element had no vapor suppression system or barrier coating between the 316 stainless-steel hot cap and $(\mathrm{Cu}, \mathrm{Ag})_{2} \mathrm{Se}$. These deletions were intended to directly compare zero-current operations of a segmented element in a thermal gradient test. The test conditions caused the copper and the hot cap materials to move down the element. A gap developed at the $(\mathrm{Cu}, \mathrm{Ag})_{2} \mathrm{Se}-\mathrm{mesh} /$ hot cap interface and caused the test to be terminated.

A replacement test (6875-146-2) was substituted with a tungsten barrier coating on the hot cap. Resistivity changes in this element were monitored as a function of iL/A for six thermal gradients. Figure 2-29 shows the results of these examinations for the $(\mathrm{Cu}, \mathrm{Ag})_{2} \mathrm{Se}$ segment. Resistivity values for the $(\mathrm{Bi}, \mathrm{Sb})_{2} \mathrm{Te}_{3}$ segment were relatively uniform and were thus not plotted.

For each of the thermal gradients examined, the higher the iL/A, the lower the resistivity of the $(\mathrm{Cu}, \mathrm{Ag})_{2} \mathrm{Se}$ segment. One reason speculated for this is that a larger fractional current is carried by ions at larger iL/A values. Enhanced vaporization of $(\mathrm{Cu}, \mathrm{Ag})_{2} \mathrm{Se}$ as $\mathrm{iL} / \mathrm{A}$ is increased (i.e., more copper ions) gives credence to this argument. The resistivity of this segment decreases as the average temperature of the material increases. Above a $\mathrm{T}_{\mathrm{H}}$ of $400^{\circ} \mathrm{C}$, the resistivity of the segment appears to be controlled by the higher resistance of the cold end of the segment. 


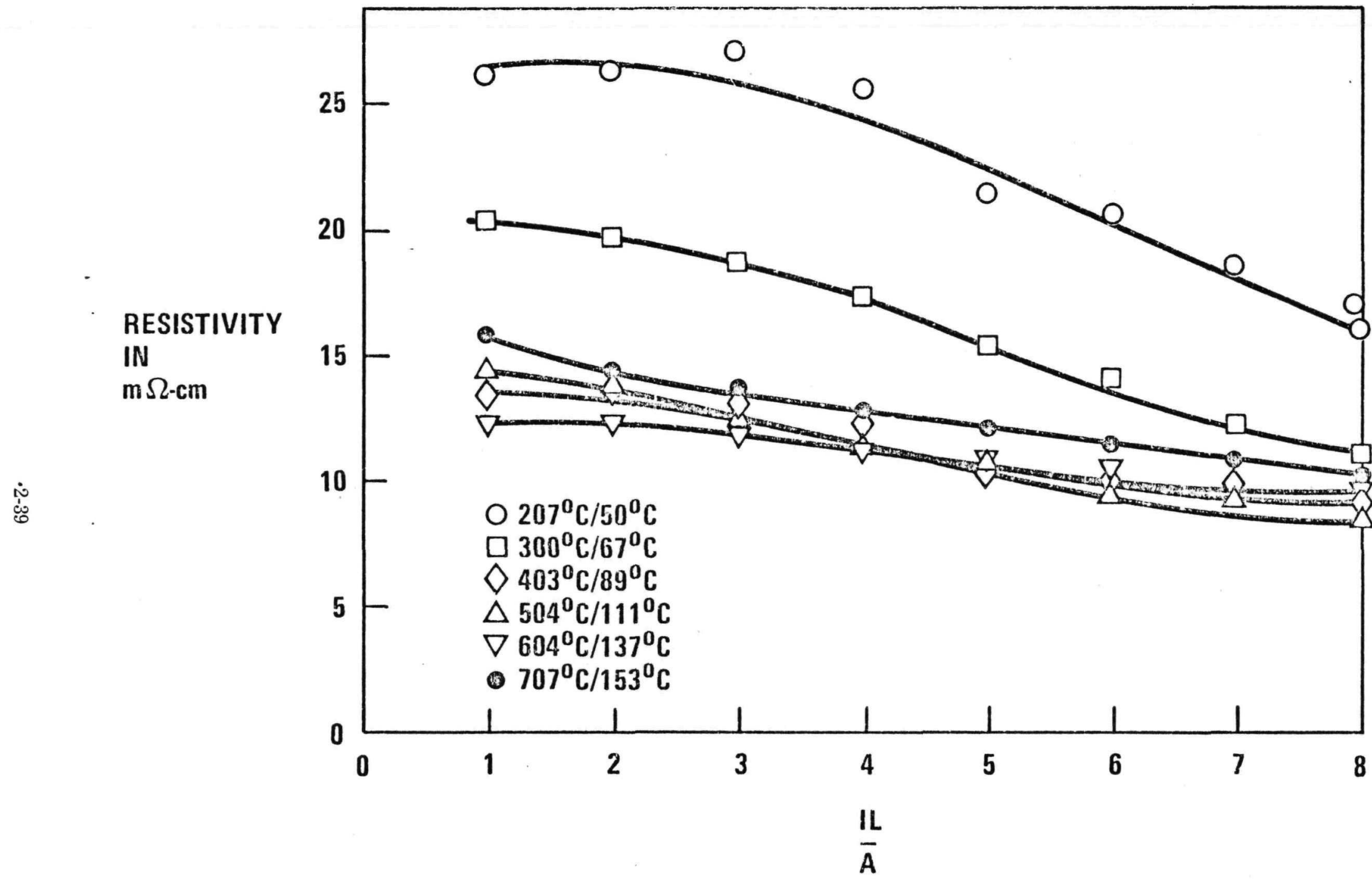

Fig. 2-29. Resistivity values for the (Cu, Ag).., Se segment of a doubly segmented $(\mathrm{Cu}, \mathrm{Ag})$.. Se/ $\mathrm{Fe} /(\mathrm{Bi}, \mathrm{Sb}) . . \mathrm{Te}_{;}$element $6875-146-2$ as a function of $\mathrm{iL} / \mathrm{A}$ and thermal yradient 
2.2.3.2. Ratcheting. General Atomic investigated ratcheting of $\mathrm{V}_{2}$ and, thus, calculated resistance, assuming that $\mathrm{V}_{0}$ is constant, in P-type $(\mathrm{Cu}, \mathrm{Ag})_{2} \mathrm{Se}$. Ratcheting is an irregular phenomena that requires many test hours to establish (Fig. 2-30) (that is, it is cyclic, but the cycle frequency is somewhat irregular). The ratchet pattern is dependent on current in the general manner shown in Fig. 2-31. In spite of short-term irregularity, if the average cycle frequencies are plotted versus $\mathrm{iL} / \mathrm{A}$ for a large number of ratchet cycles, a curve typical of the one shown in Fig. 2-32 results. At iL/A values above the maximum cycle frequency, open circuit measurements temporarily threw the element into its low resistivity mode. Figure $2-33$ shows that the iL/A also affected the time spent by each cycle in the low resistivity mode.

Geometry and temperature also influence ratcheting. Figure 2-34 shows ratcheting to be sensitive to either or both geometry and temperature. Two segmented and one unsegmented sample with differing geometries and $\mathrm{T}_{\mathrm{C}}$ had peak ratcheting frequencies at different values of iL/A. Similarly, the ratchet behavior of one element is different even if $\mathrm{T}_{\mathrm{C}}$ is the only variable (Fig. 2-35).

Ratcheting occurred with molybdenum-, tungsten-, and rhenium-coated hot caps. Metallographic examination (Fig. 2-36) showed that the $(\mathrm{Cu}, \mathrm{Ag})_{2} \mathrm{Se}$ of ratchet sample 6875-146-2 still had intimate contact with the wire mesh. Thus, neither cap material nor hot cap contact appeared to cause ratcheting. No change in $\mathrm{T}_{\mathrm{H}}$ or current occurred which could account for the change in the calculated resistivity observed.

The magnitudes of calculated resistance changes during ratcheting of $(\mathrm{Cu}, \mathrm{Ag})_{2} \mathrm{Se}$ were estimated for segmented and unsegmented elements. Figures 2-37 and 2-38 show the results. The amplitudes of the voltage changes for each element are nearly the same for all values of iL/A except for very low current flows. When translated to resistance, the fractional change in resistance is minimum at the highest $\mathrm{iL} / \mathrm{A}$ values where ratcheting occurs. The resistance change during ratcheting, like the ratchet cycle frequency, appears to be related to the geometry and temperature profile of the $(\mathrm{Cu}, \mathrm{Ag})_{2} \mathrm{Se}$ segment. Data on ratcheting were insufficient to quantify or verify these assumed relationships.

Specimen geometry is also speculated to affect voltage-time behavior of the tested element. Examples of this occurred in two test elements in which the mesh joint was connected on the element circumference to the hot cap. One segmented $(\mathrm{Cu}, \mathrm{Ag})_{2} \mathrm{Se} /$ $\mathrm{Fe}(\mathrm{Bi}, \mathrm{Sb})_{2} \mathrm{Te}_{3}$ element, 8236-3-1B, and one nonsegmented $(\mathrm{Cu}, \mathrm{Ag})_{2} \mathrm{Se}$ element, 8236-4-1A, show this configuration-induced behavior. Both elements had Mo-47/Re hot caps. The $(\mathrm{Cu}, \mathrm{Ag})_{2} \mathrm{Se}$ segments of both elements experienced resistivity ratcheting.

In addition to resistivity ratcheting, the elements showed instantaneous open-circuit voltage ramping. As seen in Fig. 2-39, large swings were observed in the load voltages. Figures 2-40 and 2-41 show portions of the recorder tracings near the beginning of life of the load voltages across the $(\mathrm{Cu}, \mathrm{Ag})_{2}$ Se segments for these elements. Ramping had no readily detectable effect on resistivity ratcheting in the segmented element (Fig. 2-42) but occurred with measurable resistivity changes in the unsegmented element. The principal thermoelectric property change during ramping is a change in the apparent Seebeck coefficient, as shown in Figs. 2-43 and 2-44. The accompanying change in nonsegmented element resistivity (Fig. 2-45) began as not much more than the normal scatter in resistivity observed in the data. As noted earlier, $\mathrm{P}$ elements underwent ramping only when the wire mesh was attached to the rim of the hot cap. 
$\stackrel{N}{ث}$

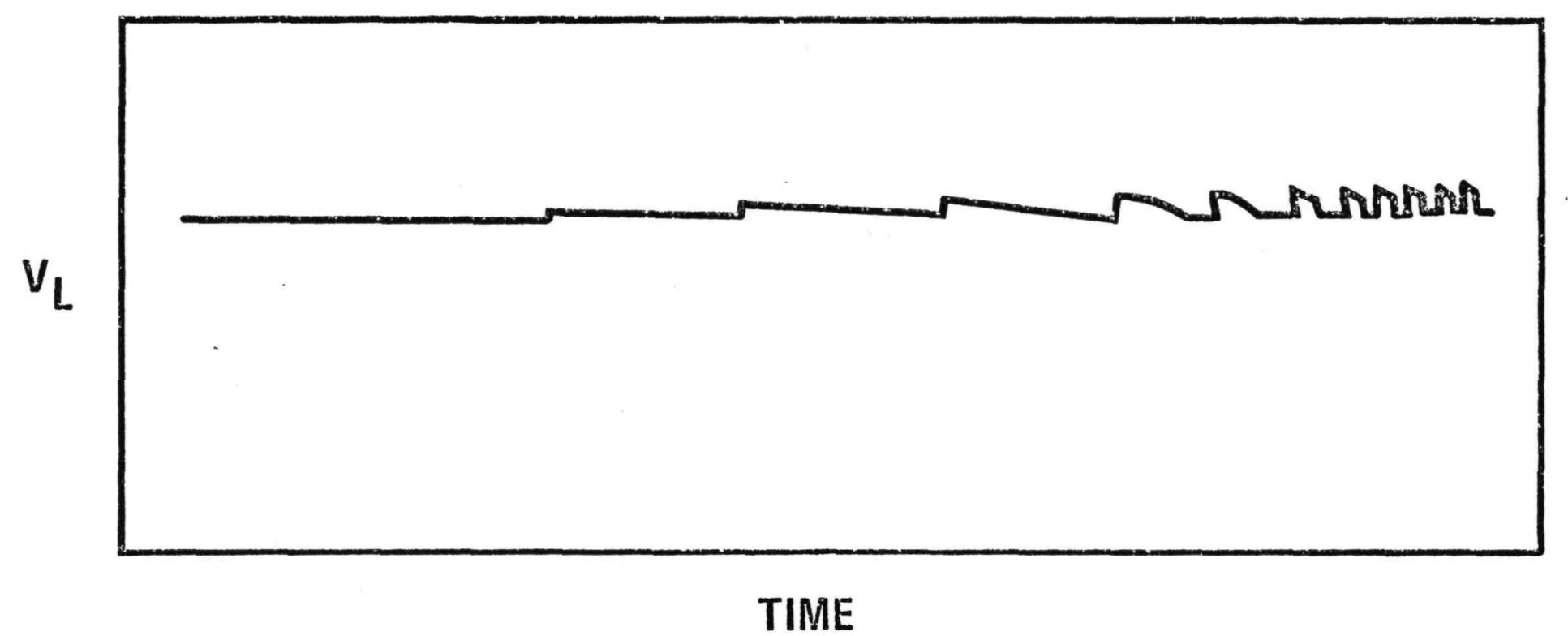

Fig. 2-30. Typical time load voltage plot showing the onset of ratcheting in $(\mathrm{Cu}, \mathrm{Ag})$., Se elements 


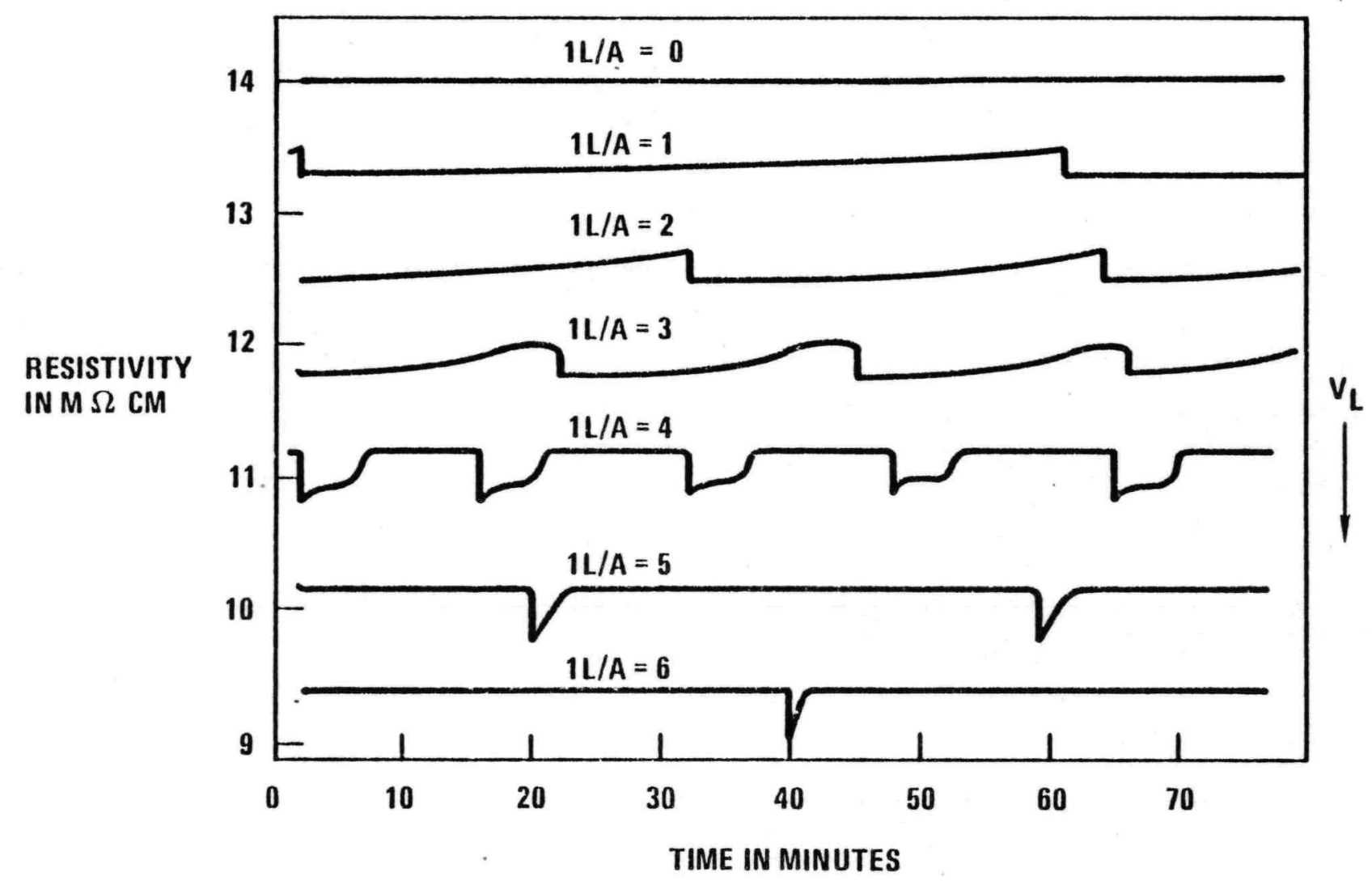

Fig. 2-31. Typical $(\mathrm{Cu}, \mathrm{Ag})_{.2}$ Se resistivity ratcheting patterns $T_{11}=750^{\circ} \mathrm{C}, T_{\mathrm{G}}=200^{\circ} \mathrm{C}$ 


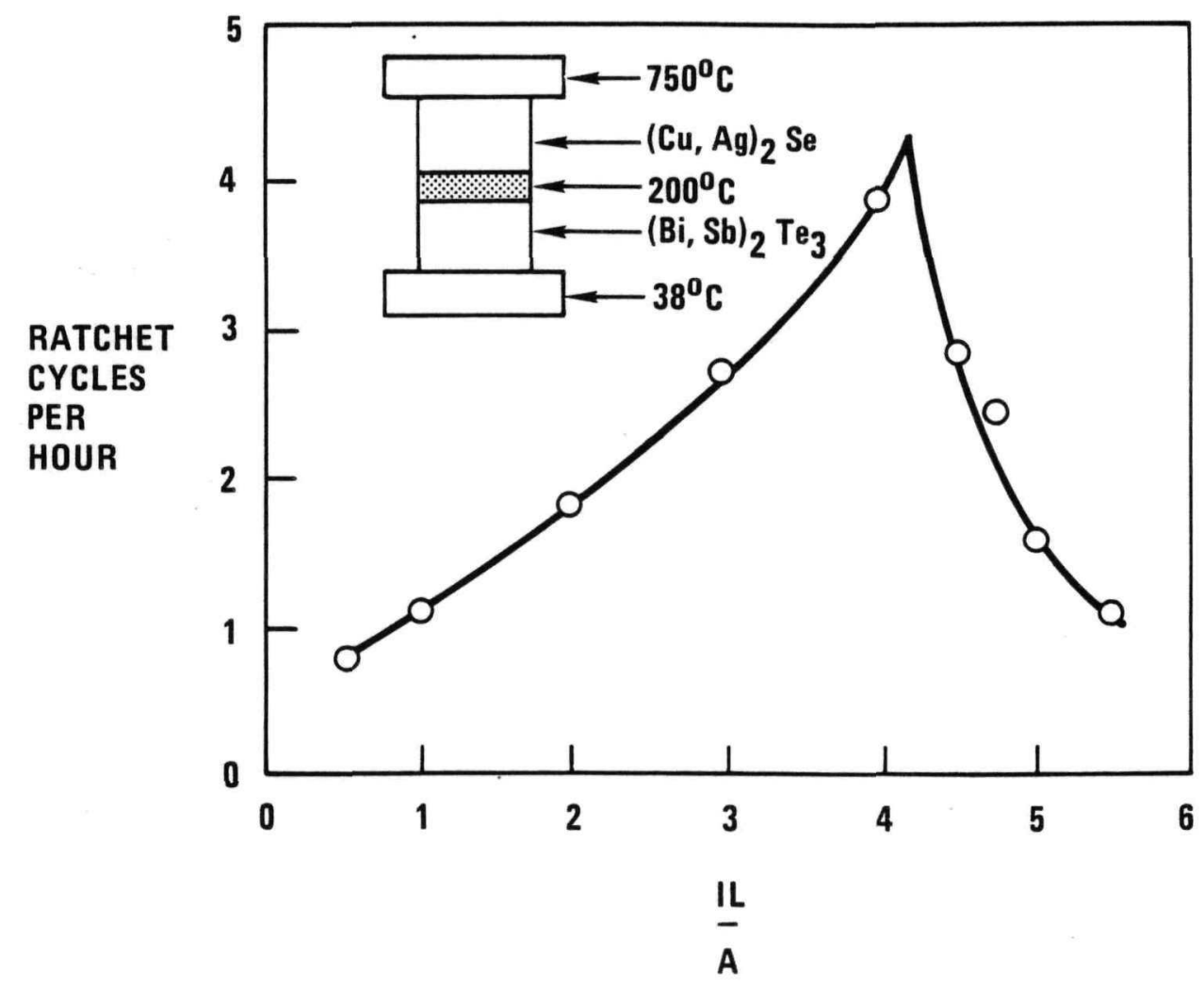

Fig. 2-32. Effect of $i L / A$ on the ratchet frequency of the (Cu, Ag).. Se segment of element 68\%5$146-2$ 


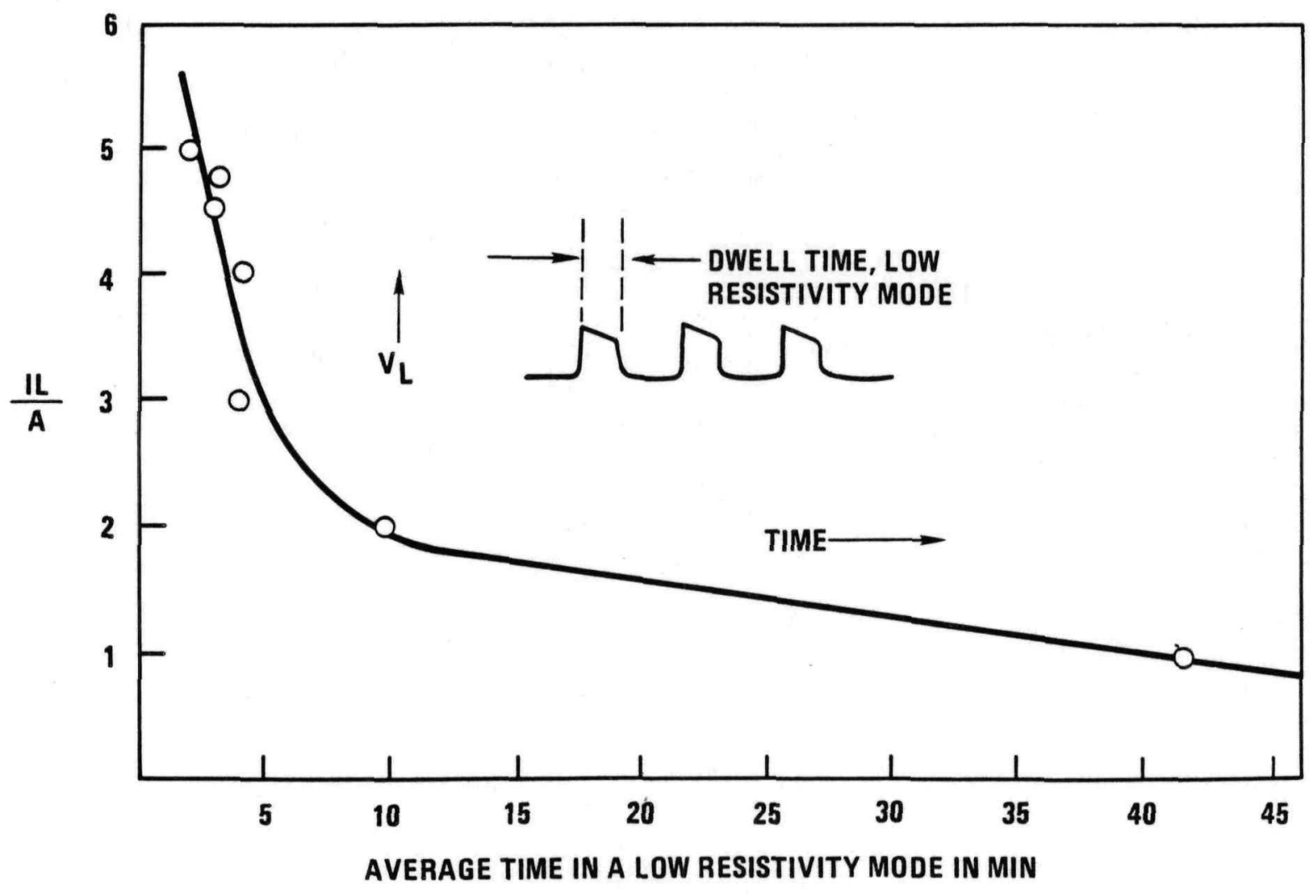

Fig. 2-33. Dwell time for $(\mathrm{Cu}, \mathrm{Ag})_{2}$. Se segment of $\mathrm{P}$ element 6875-146-2 as a function of $\mathrm{iL} / \mathrm{A}$ 


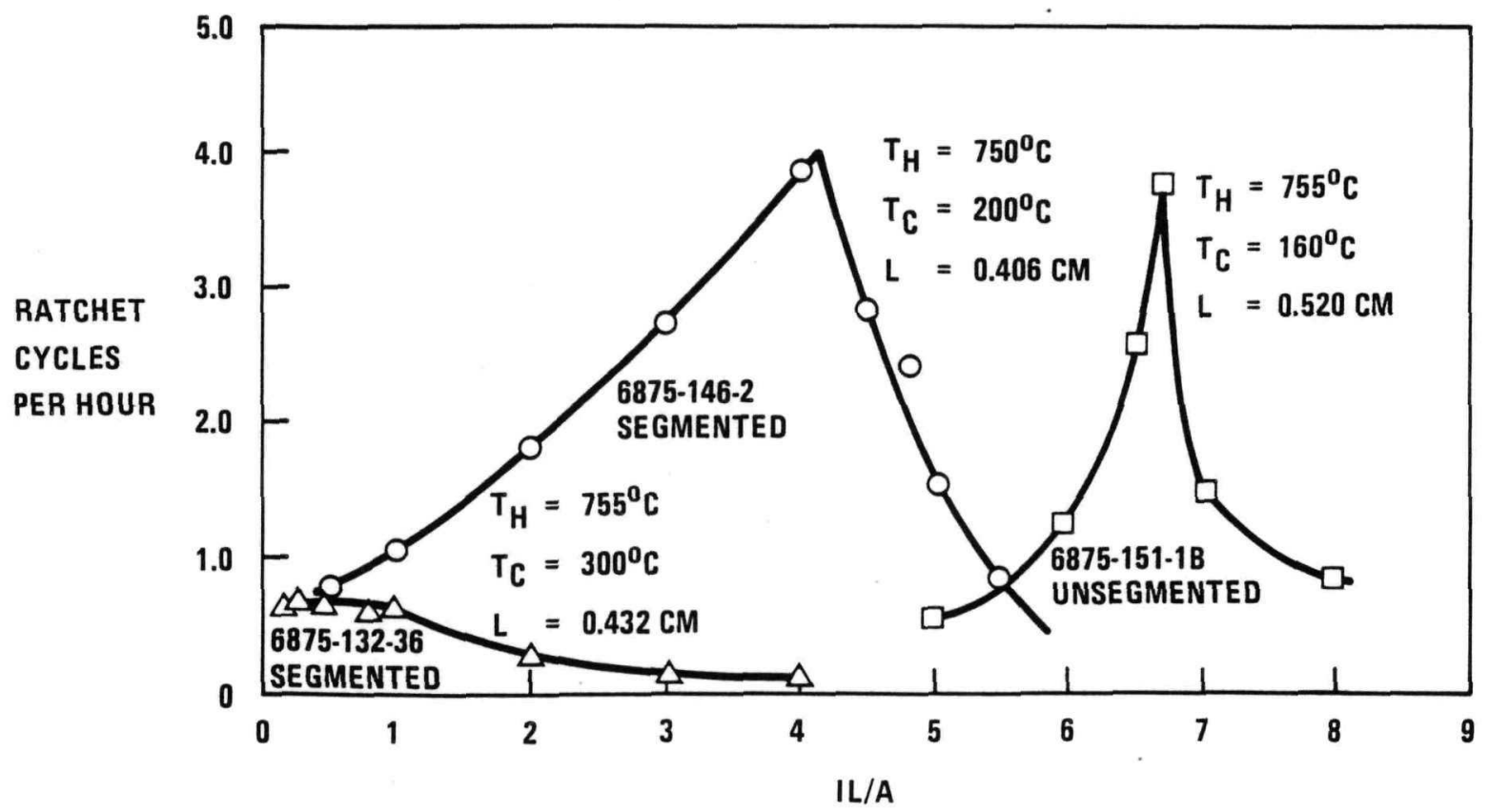

Fig. 2-34. Ratchet cycles as a function of $i L / A$ for two segmented and one unsegmented P-type elements 


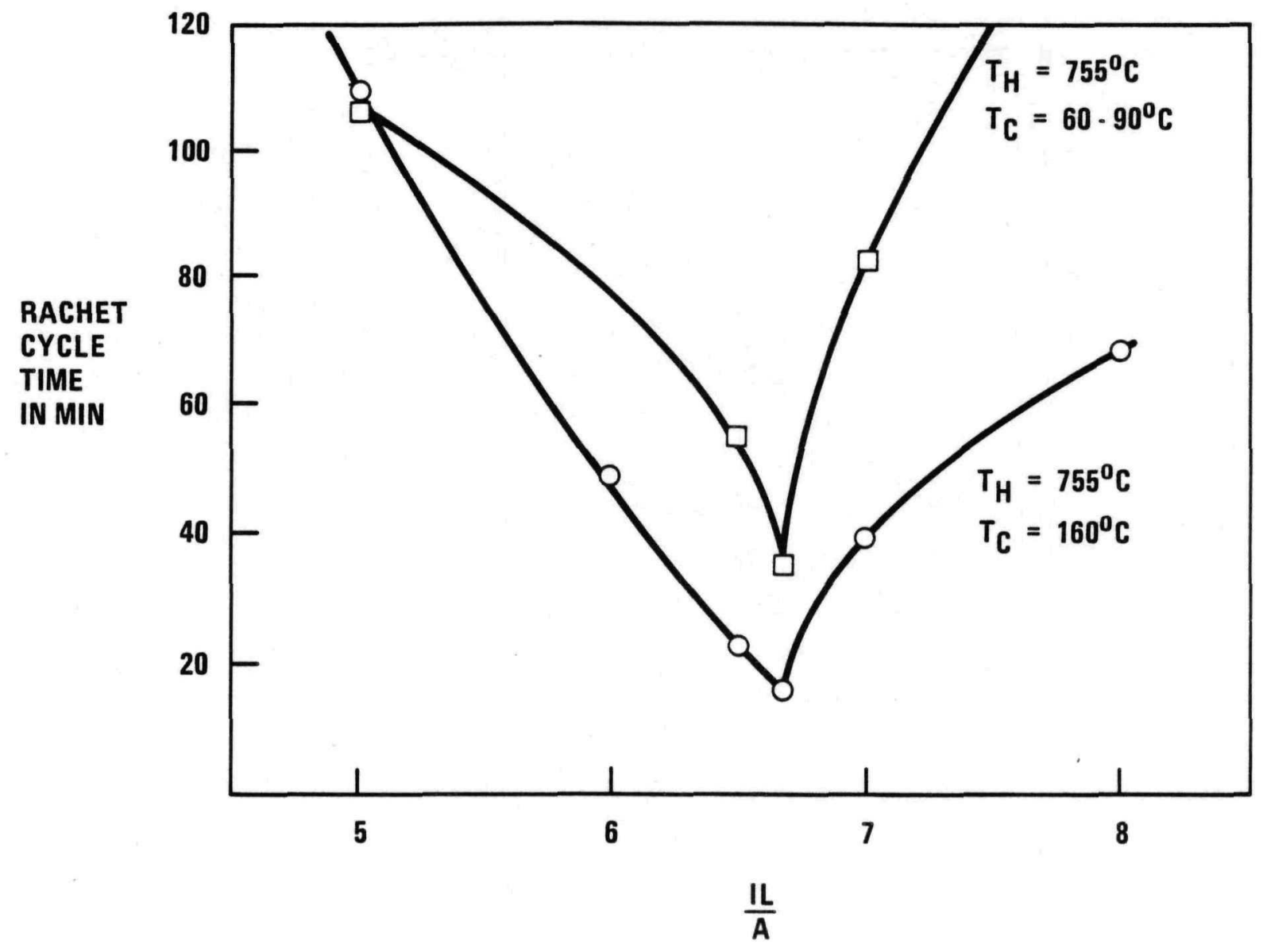

Fig. 2-35. Effect of $T_{\mathrm{C}}$ on the resistivity ratchet cycle time for $(\mathrm{Cu}, \mathrm{Ag})_{2}$. Se element $6875-151-1 B$ 


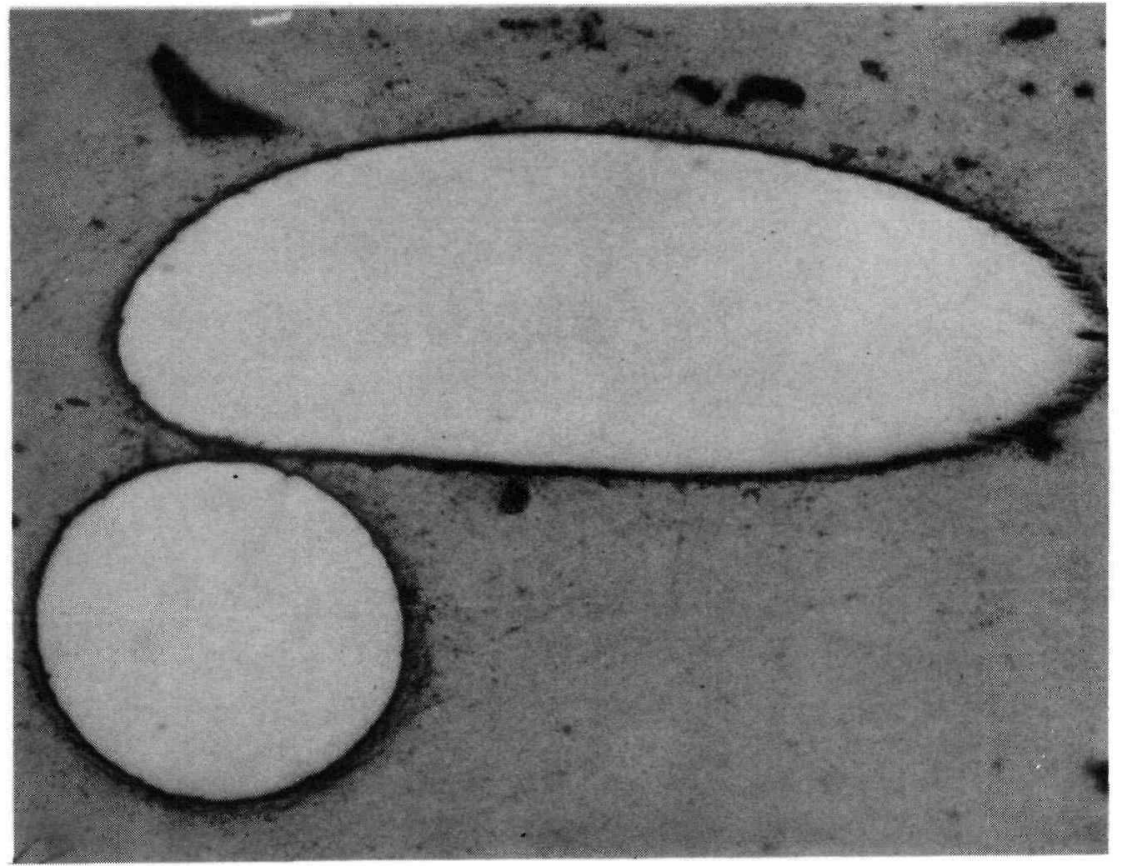

Fig. 2-36. Photomicrograph of the wire mesh/(Cu,Ag) ${ }_{2}$ Se joint region of sample 6875-146-2 after resistivity ratcheting experiments 


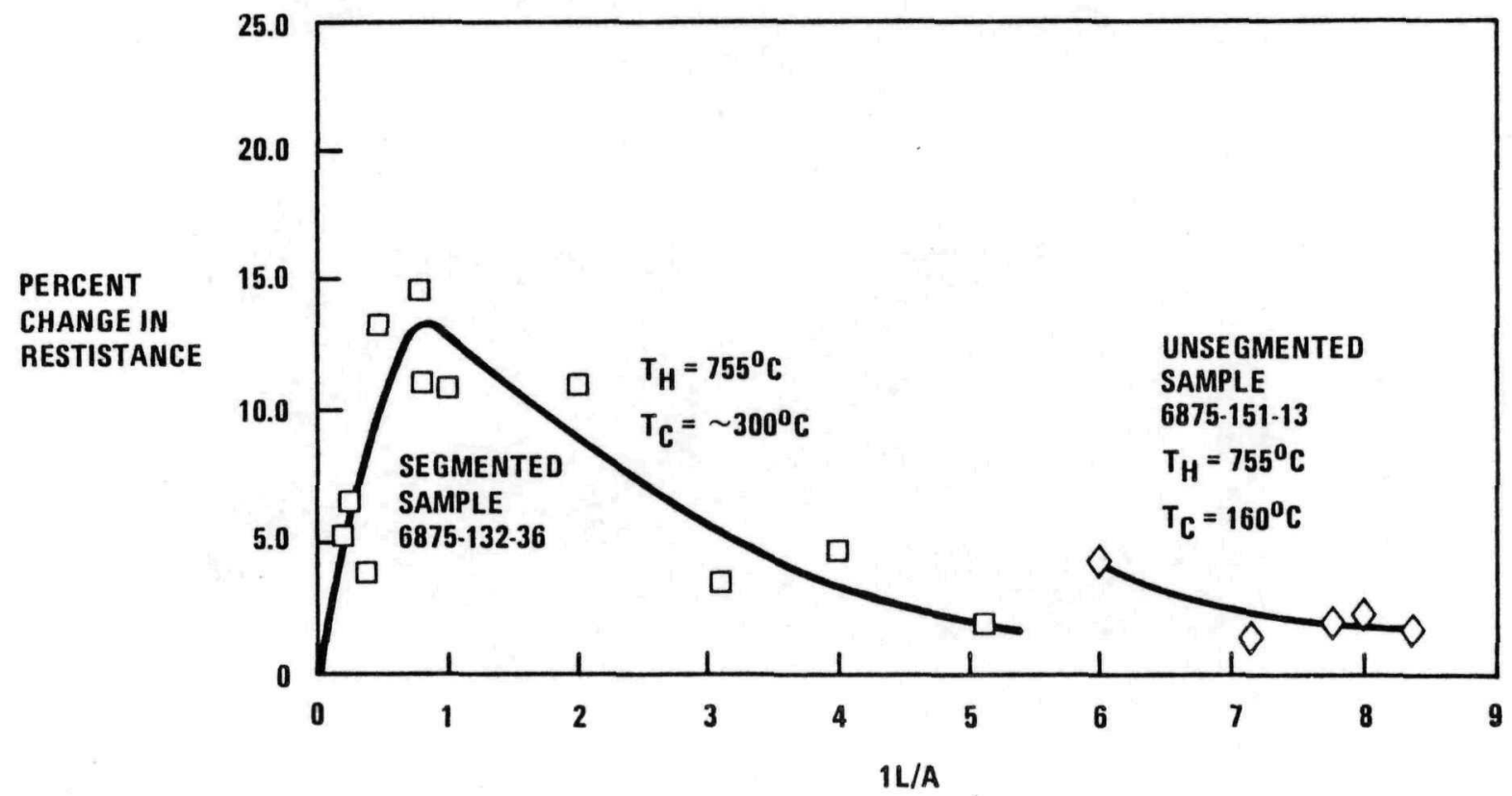

Fig. 2-37. Resistance change during ratcheting of $(\mathrm{Cu}, \mathrm{Ag})$.. Se in segmented and unsegmented elements 


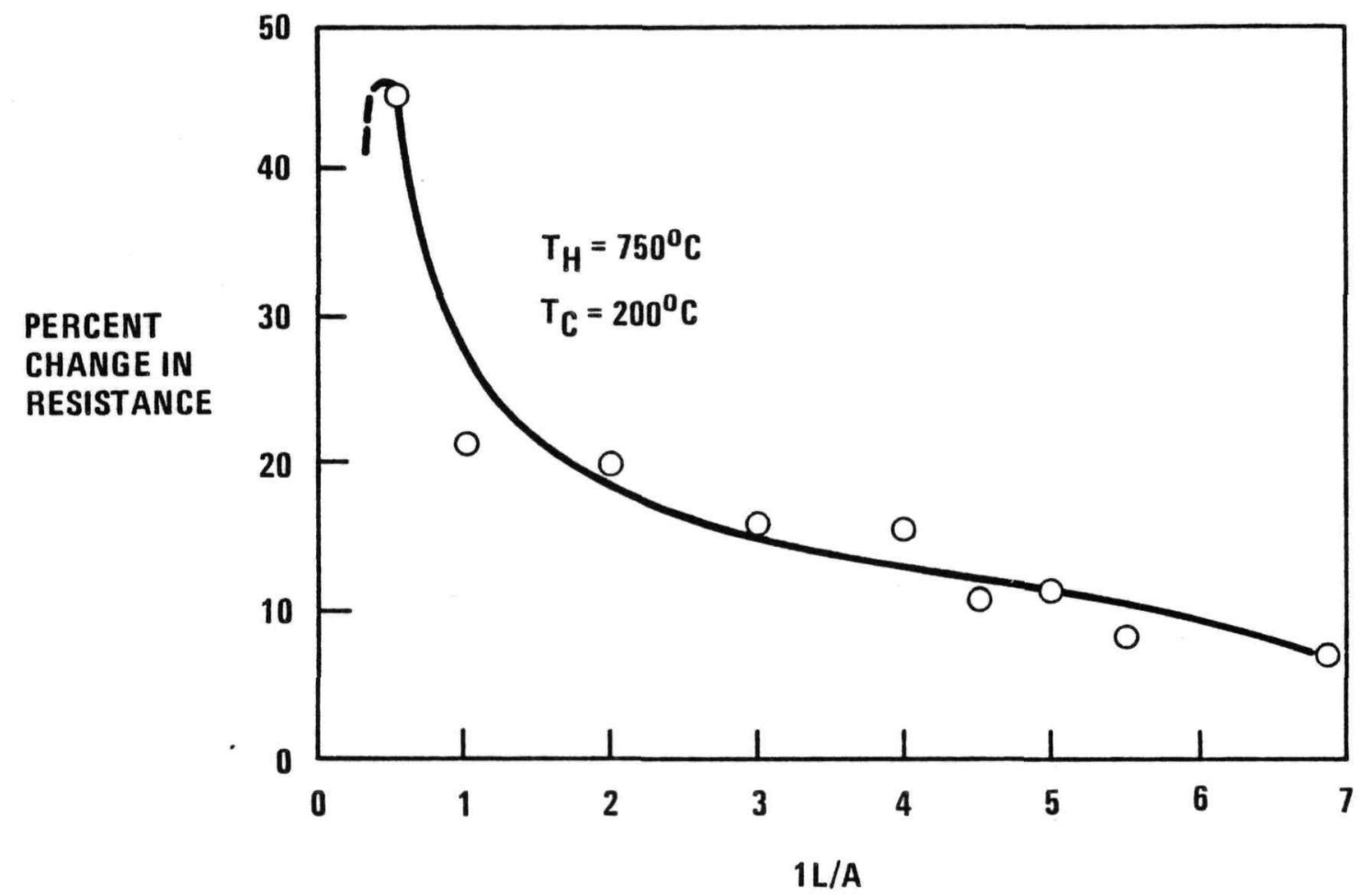

Fig. 2-38. Resistance change during ratcheting of the (Cu, $\mathrm{Ag})_{2}$. Se segment of sample 6875-146-2 


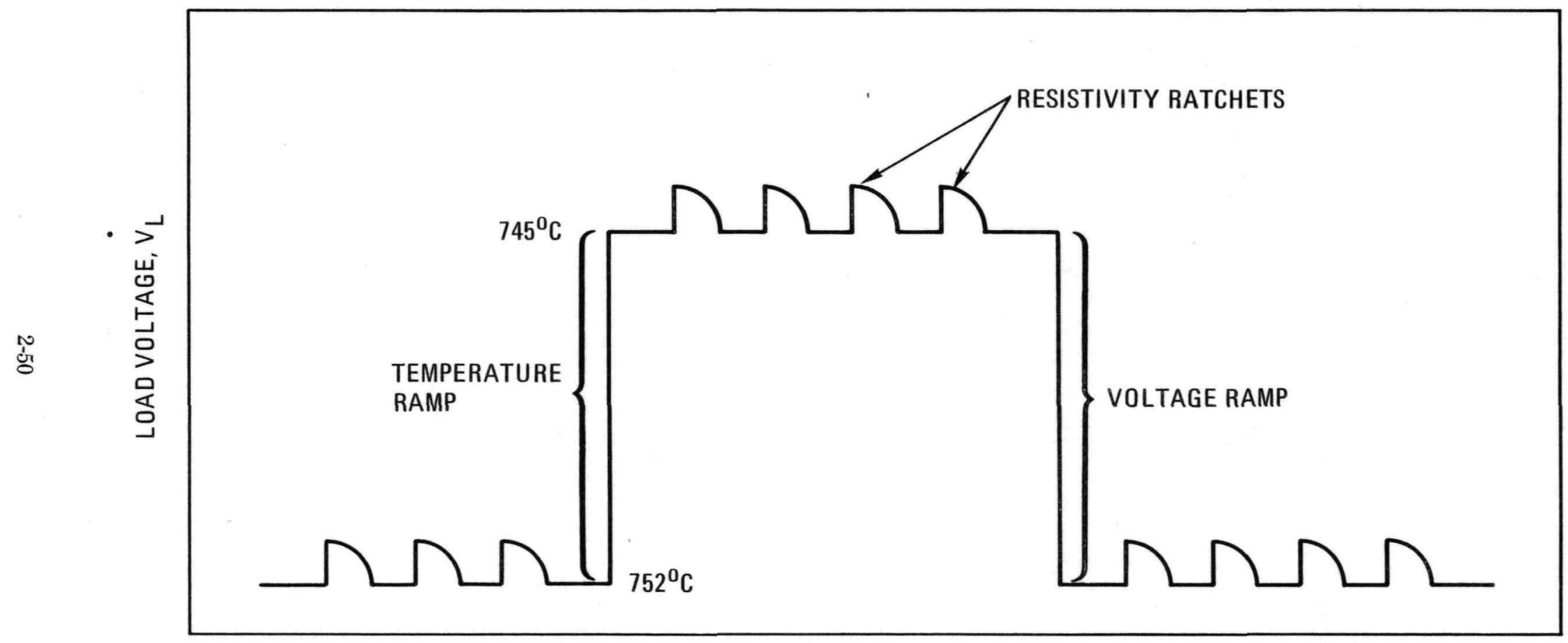

TIME

Fig. 2-39. Typical voltage ramping profile showing time, temperature, and load voltage behavior of edge tack-welded mesh $(\mathrm{Cu}, \mathrm{Ag})_{2}$ Se elements operating in a thermal gradient with current 


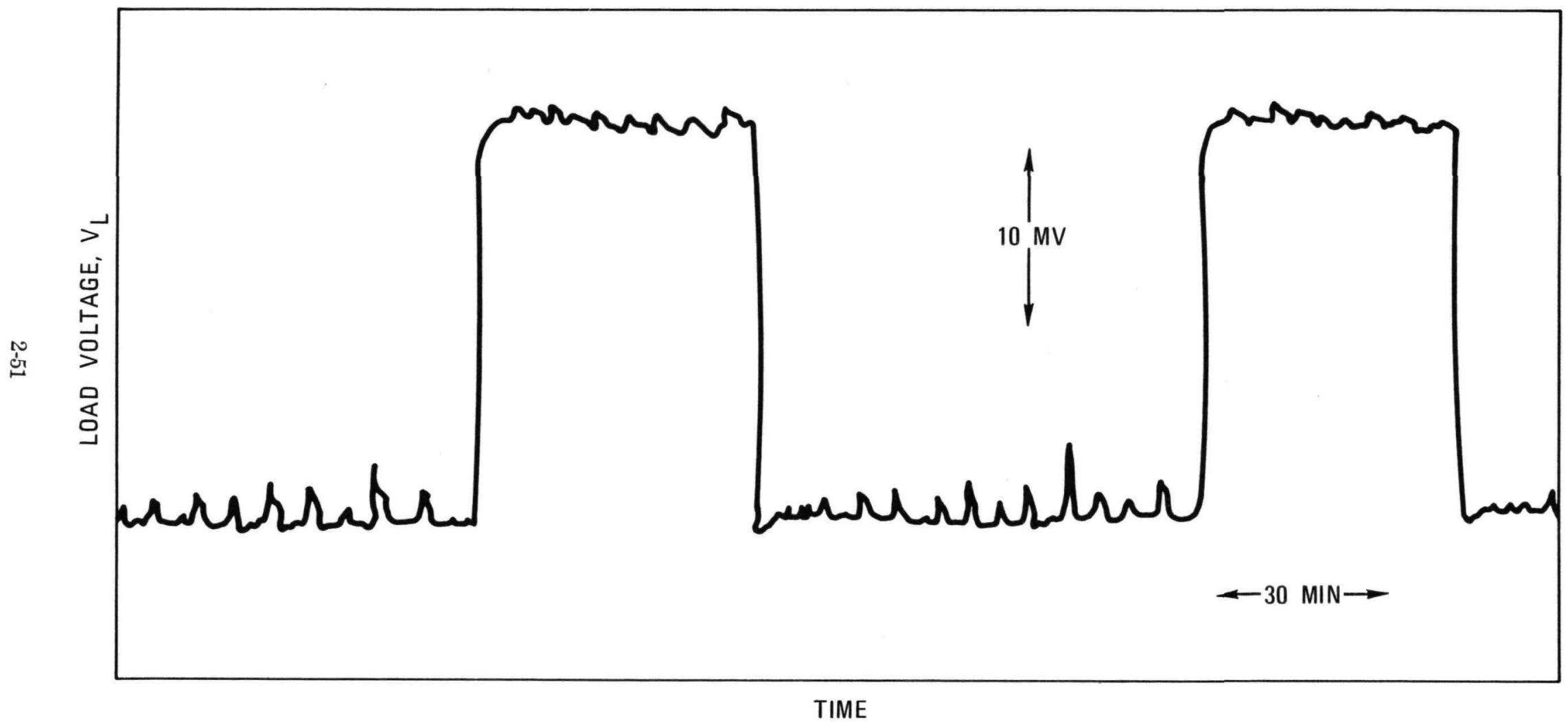

Fig.. 2-40. Load voltage of unsegmented (Cu,Ag) Se of element 8236-4-1A 


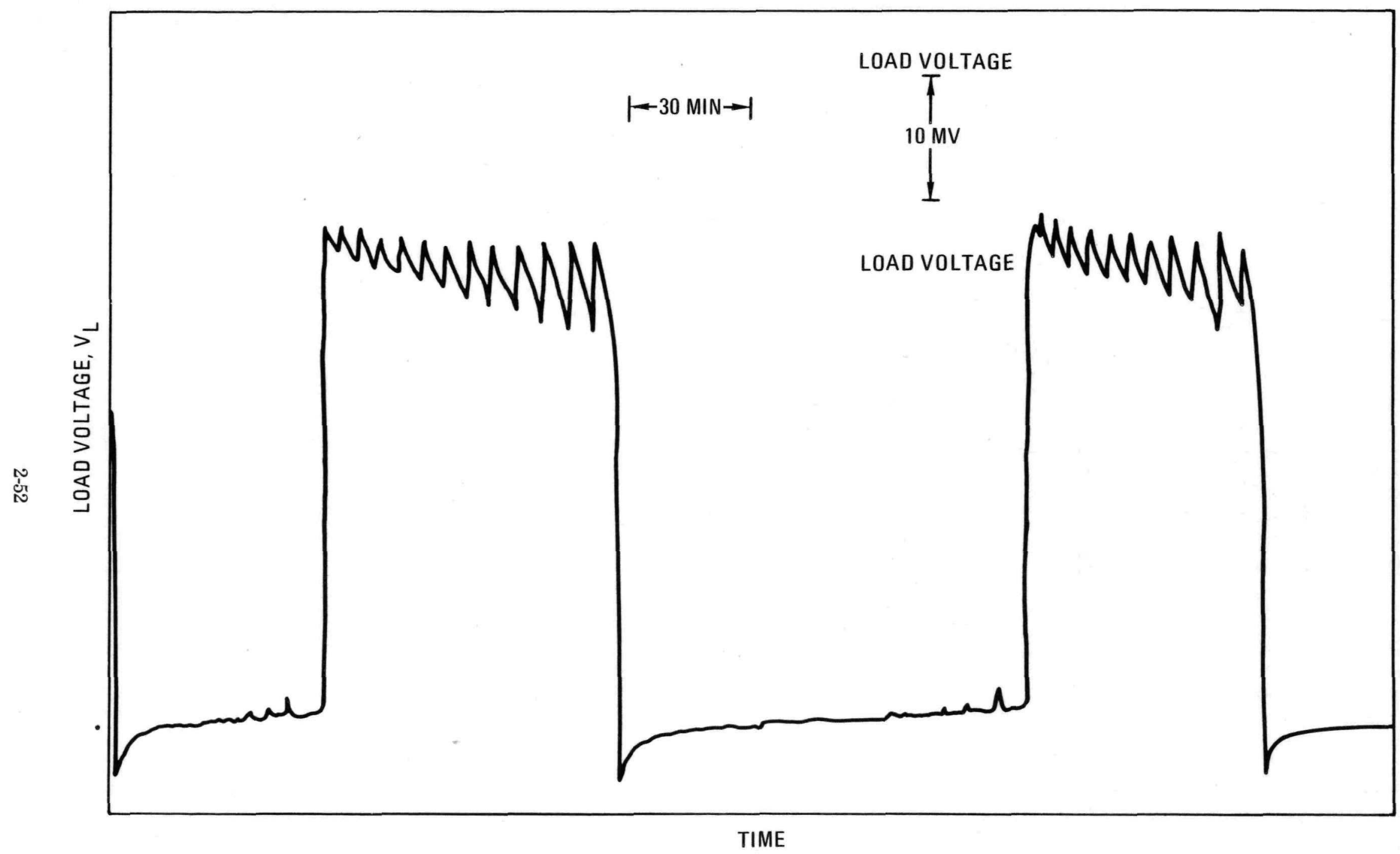

Fig. 2-41. Load voltage for $(C u, A g)$.SSe segment of element 8326-3-1B 


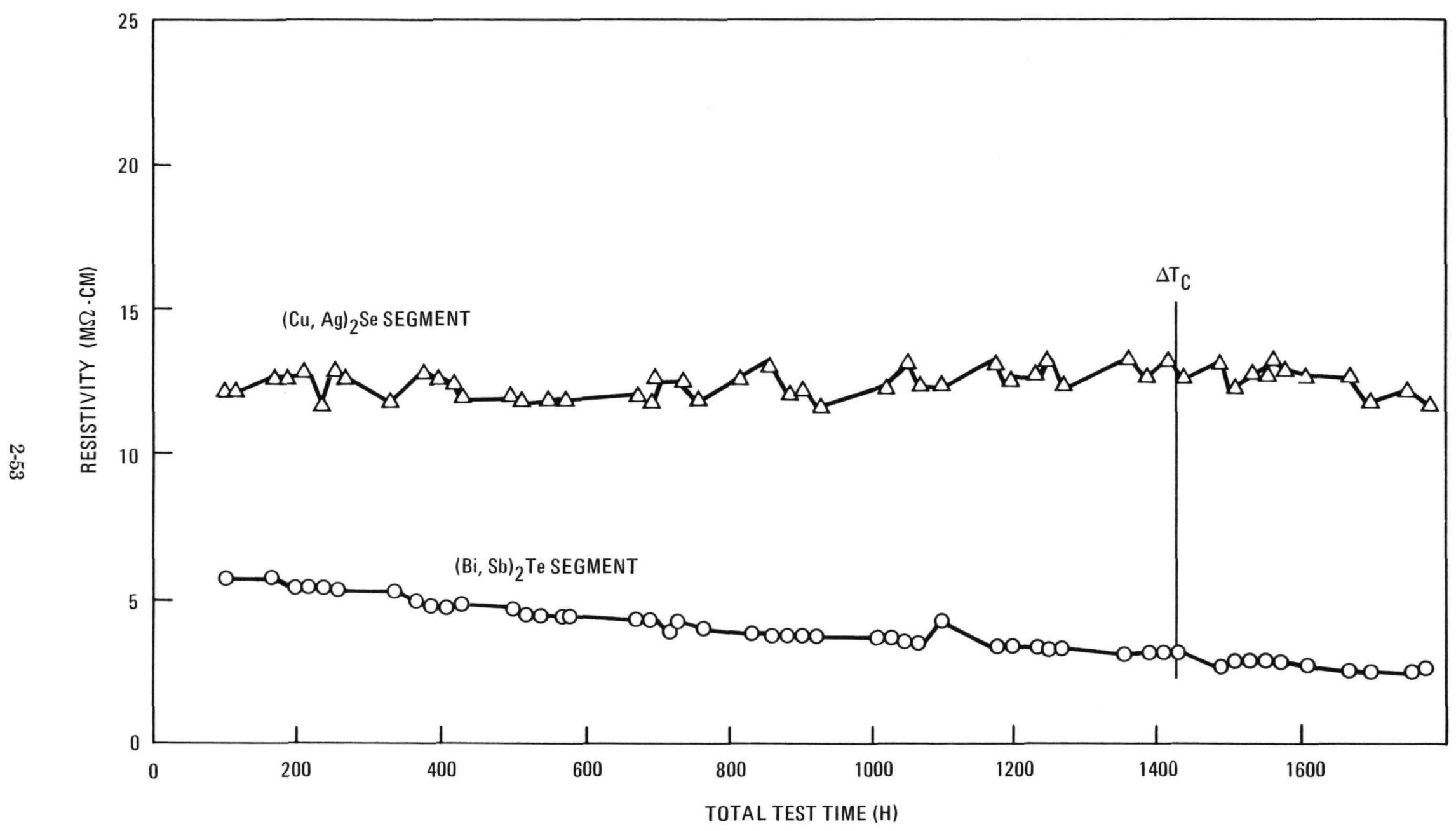

Fig. 2-42. Resistivity values of segmented P-type element 8236-3-1B tested in a thermal gradient of $755^{\circ} \mathrm{C} / 237^{\circ} \mathrm{C} / 160^{\circ} \mathrm{C}$ at an $i \mathrm{~L} / \mathrm{A}$ value of 7.4 across the $(\mathrm{Cu}, \mathrm{Ag})$. Se segment 


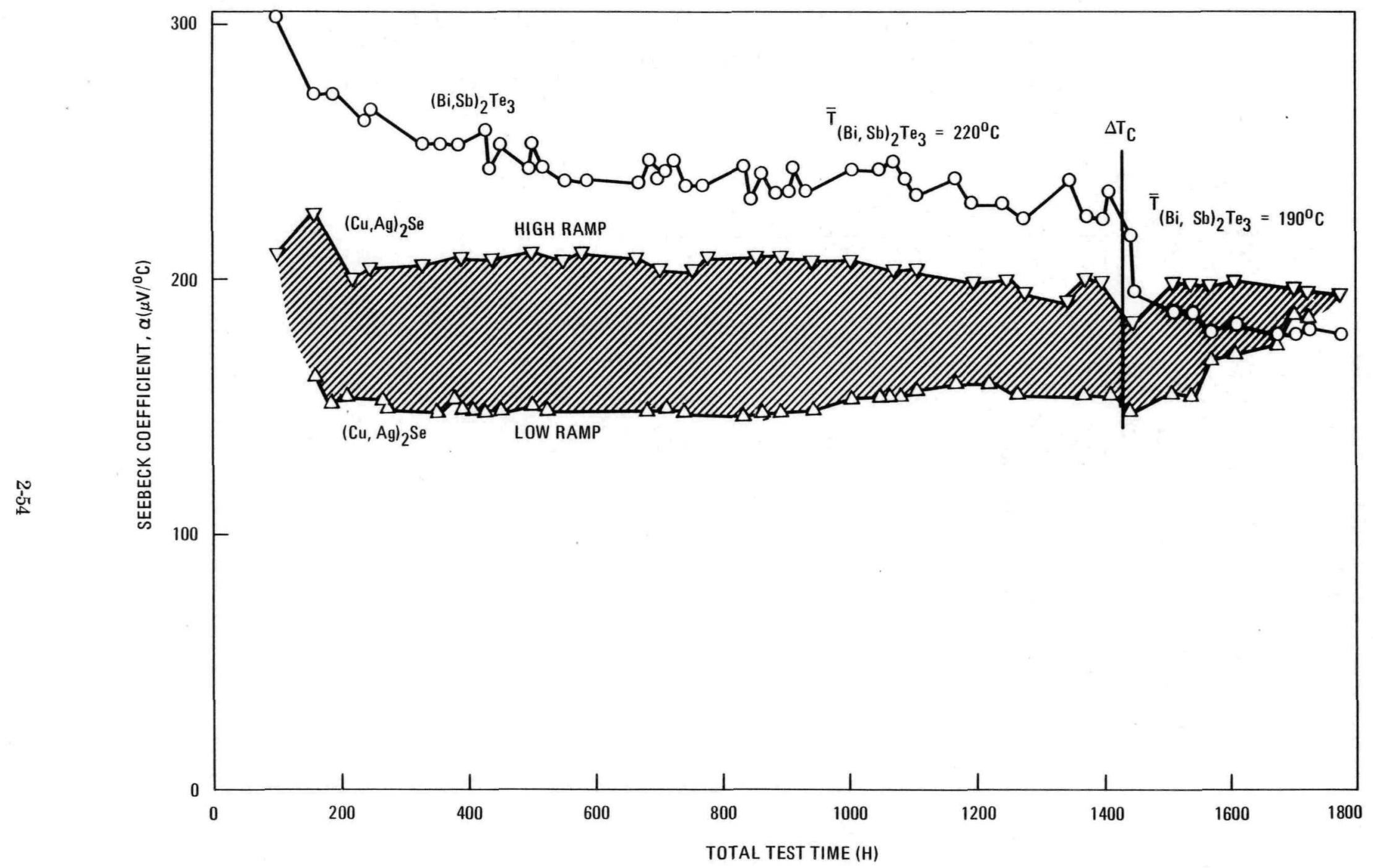

Fig. 2-43. Seebeck coefficients of segmented P-type element 8236-3-1B tested in a thermal gradient of $755^{\circ} \mathrm{C} / 237^{\circ} \mathrm{C} / 160^{\circ} \mathrm{C}$ at an $i L / A$ value of 7.4 across the $(\mathrm{Cu}, \mathrm{Ag}){ }_{2} \mathrm{Se}$ segment 


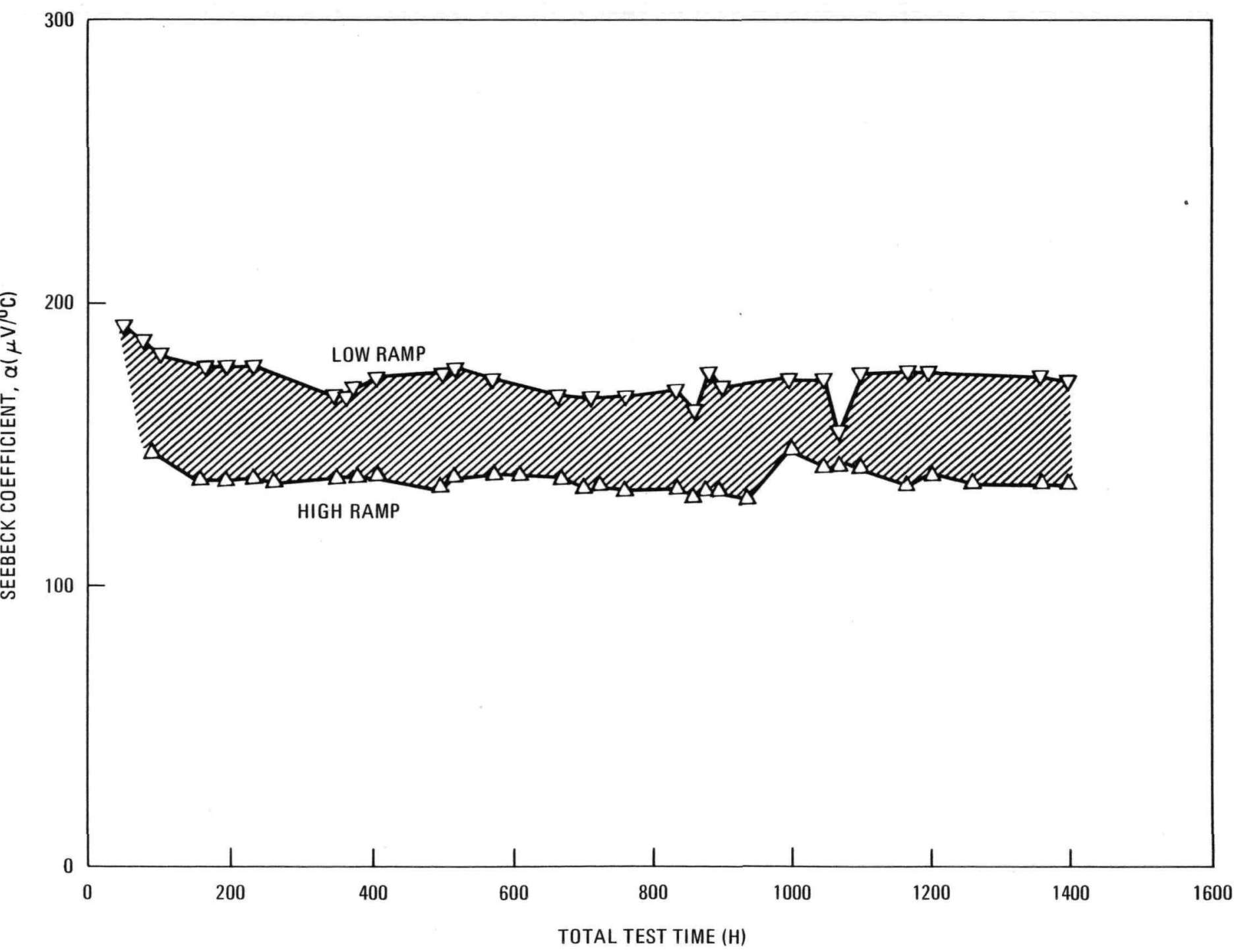

Fig. 2-44. Seebeck coefficients of unseymented P-type element 8236-4-1A tested in a thermal gradient of $755^{\circ} \mathrm{C} / 124^{\circ} \mathrm{C}$ at an $i L / A$ value of 7 


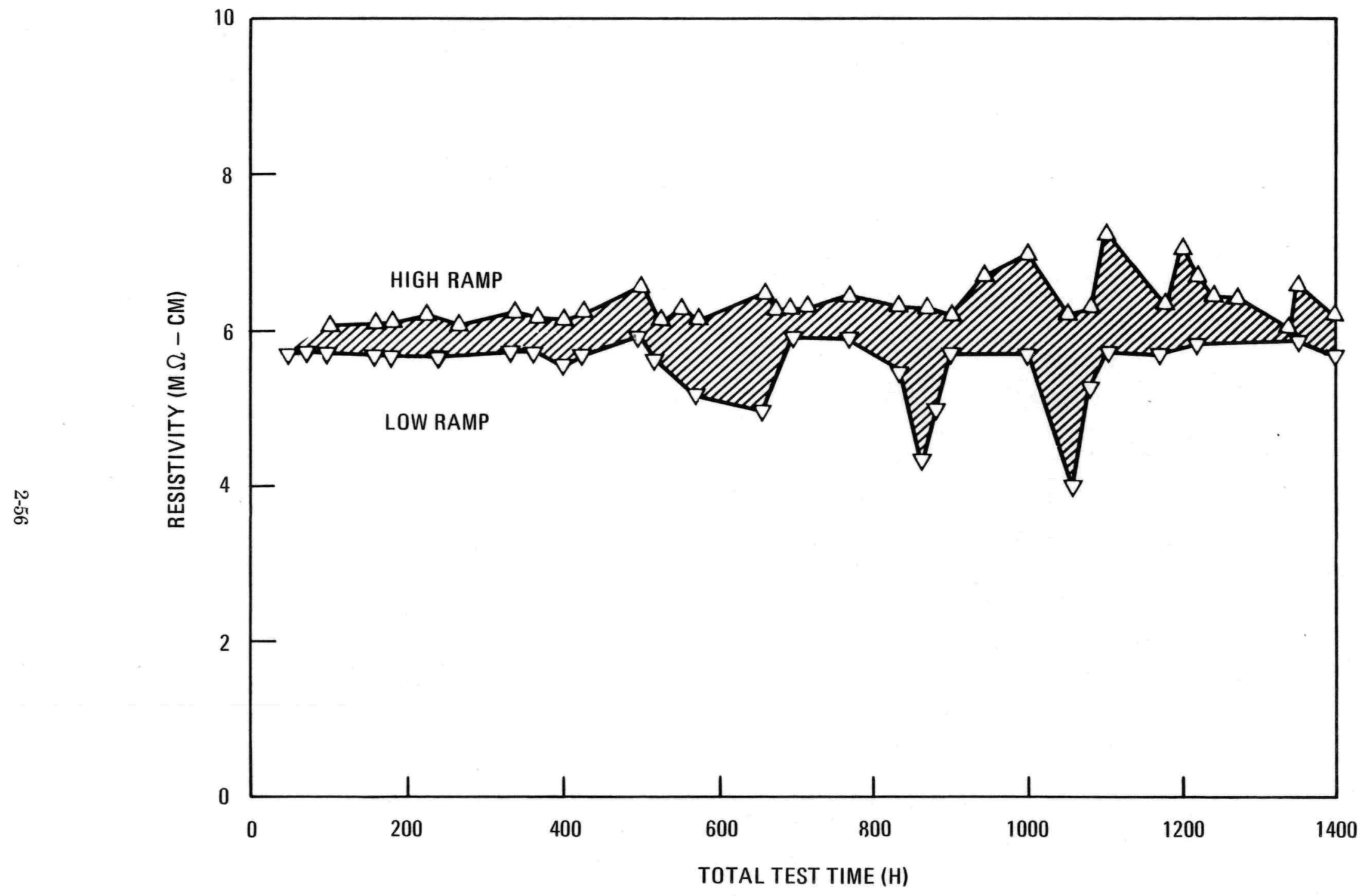

Fig. 2-45. Resistivity values of unsegmented P-type element 8236-4-1A tested in a thermal gradient of $755^{\circ} \mathrm{C} / 124^{\circ} \mathrm{C}$ at an $i L / A$ value of 7 
Ramping may be an artifact created by the hot-cap-to-element-joint configuration. The wire mesh of this element was tack-welded to the rim of the hot cap. The element had no bonded contact with the center of the hot cap. This ramping is speculated to be caused by cyclic changes in the actual $\mathrm{T}_{\mathrm{H}}$ of the element. The $\mathrm{T}_{\mathrm{H}}$ was monitored at the hot cap and did not account for the $\Delta \mathrm{T}$ caused by a changing gap between the hot cap and the $(\mathrm{Cu}, \mathrm{Ag})_{2}$ Se segment.

Initially, the hot cap and the element are in contact, as shown in Fig. 2-46. The measured and actual $\mathrm{T}_{\mathrm{H}}$ temperatures are therefore nearly the same at the beginning of the test. Current flow causes the $(\mathrm{Cu}, \mathrm{Ag})_{2} \mathrm{Se}$ segment to cool. The $(\mathrm{Cu}, \mathrm{Ag})_{2} \mathrm{Se}$ then shrinks away from contact with the hot cap, as shown in Fig. 2-47. A step drop in Seebeck coefficient then occurs. The difference between the assumed $\mathrm{T}_{\mathrm{H}}$ and the actual $\mathrm{T}_{\mathrm{H}}$ becomes large, and the calculated Seebeck coefficient becomes much lower as the $\Delta \mathrm{T}$ across the element is lowered. As the current is decreased and the element is thus warmed, it again expands until it touches the hot cap. This contact causes a sharp increase in the $\mathrm{T}_{\mathrm{H}}$ of the $(\mathrm{Cu}, \mathrm{Ag})_{2} \mathrm{Se}$ and a corresponding step increase in the Seebeck coefficient.

The difference in the Seebeck coefficient and resistivity for the unsegmented and segmented elements is probably more artificial than actual. Copper transported down the thermal gradient precipitates at a temperature warmer than the cold cap, and thus before it reaches the cold cap, precipitation has been seen in all the elements tested in a thermal gradient where the cold end is less than $200^{\circ} \mathrm{C}$. This precipitation shortens the effective length of the element which is contributing to the thermoelectric potential and thus makes Seebeck coefficient and resistivity appear lower than they truly are. Speculating that ratcheting indicates copper movement in $(\mathrm{Cu}, \mathrm{Ag})_{2} \mathrm{Se}$, Fig. $2-48$ presents one possible scenario for ratcheting.

2.2.3.3. $\quad \mathrm{Cu}, \mathrm{Ag}_{2} \mathrm{Se}$ Thermodynamics and Transport Phenomena. The experimental observation of copper movement prompted a theoretical examination of transport phenomena in $\mathrm{Cu}_{2} \mathrm{Se}$. Appendix $\mathrm{A}$ gives an abbreviated overview of copper movement in $\mathrm{Cu}_{2} \mathrm{Se}$.

2.2.3.4. Thermal Gradient Testing of P-Type Elements. Test sample 6875-132-36 was a segmented $(\mathrm{Cu}, \mathrm{Ag})_{2} \mathrm{Se} / \mathrm{Fe} /(\mathrm{Bi}, \mathrm{Sb})_{2} \mathrm{Te}_{3}$ element with a molybdenum-coated stainless-steel hot cap and a molybdenum wire mesh. Test sample 6875-151-18 was an unsegmented $(\mathrm{Cu}, \mathrm{Ag})_{2} \mathrm{Se}$ element with a rhenium-coated stainless-steel cap and a $\mathrm{W} / 3 \%$ Re wire mesh. These test elements were used in resistivity ratcheting tests which were kept on test at iL/A values of 8 and 9.58, respectively. These tests were intended to determine if the characteristics of resistivity ratcheting changes with time. Another goal of these tests was to qualitatively evaluate life behavior of these elements in a thermal gradient with high current operation. Sample 6875-132-36 had accumulated $506 \mathrm{~h}$ in thermal gradient resistivity ratcheting tests before the high-current life tests began. The $\mathrm{iL} / \mathrm{A}$ values for these ratcheting tests varied from 0.2 to 4 . Sample $6875-151-1 \mathrm{~B}$ operated for $475 \mathrm{~h}$ in thermal gradient resistivity ratcheting experiments before its high current life testing. The iL/A values for the resistivity ratcheting tests of sample $6875-151-1 \mathrm{~B}$ varied from 6 to 9.58 . 


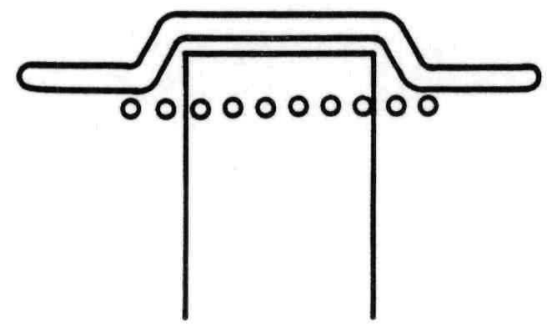

Fig. 2-46. As-fabricated mesh-in-cap design where wire mesh only is tack-welded to the hot cap

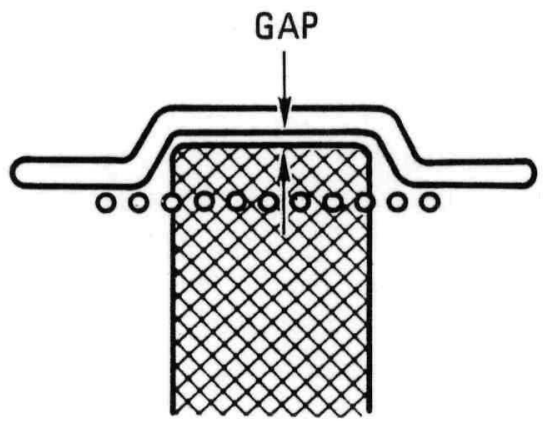

Fig. 2-47. Mesh-in-cap design where wire mesh only is tack-welded to the hot cap at operating temperatures 
NO CURRENT IN A THERMAL GRADIENT

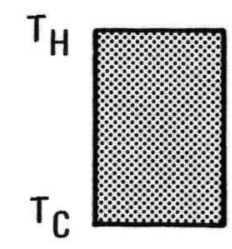

BEGINNING OF LOW CURRENT IN A THERMAL GRADIENT

AFTER MANY HOURS OF CURRENT OPERATION IN A

$\mathrm{T}_{\mathrm{C}}$

CONTINUED OPERATION

OF CURRENT AND

THERMAL GRADIENT

Cu/Se RATIO ESTABLISHED BY THE TEMPERATURE PROFILE IN $\mathrm{Cu}_{2-\mathrm{x}}$ Se MATERIAL.

$\mathrm{Cu}^{+}$DRIFT TO COLD END. THIS CAUSES HIGHER CU/Se RATIOS AT THE COLD END THAN TEMPERATURE ABOVE DICTATES. THE OVERALL ELEMENT RESISTANCE INCREASES WITH TIME.
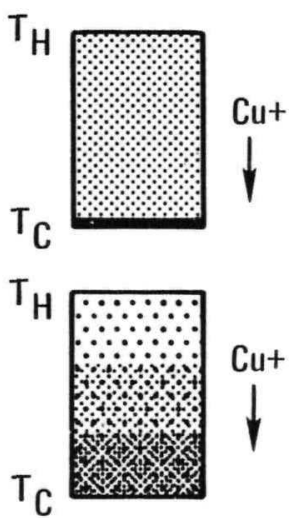

INCREASES IN CU+ CONCENTRATION AT THE COLD END OF

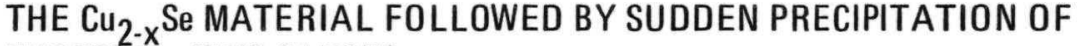
EXCESS CU. THIS CAUSES

- CYCLIC CHANGES IN THE RESISTANCE.

- gRAduAl laYer buildup OF Cu AT THE COLD END

- AN EFFECTIVE SHORTENING OF THE ELEMENT (I.E., LOWERING OF THE OUTPUT VOLTAGE).

- INCREASED POROSITY AT THE HOT END FROM Cu MIGRATION AND $\mathrm{Se}_{2}$ VAPORIZATION.

AS Cu LAYERS INCREASE (I.E., WITH TEST TIME, THE TEMPERATURE AT WHICH PRECIPITATION OF THE CU INCREASES WHICH AFFECTS THE FREOUENCY AND AMPLITUDE OF THE RESISTIVITY RATCHETING): 
Figures 2-49 and 2-50 show the Seebeck coefficient and resistivity histories of these two elements after the resistivity ratcheting experiments. Large perturbations in the Seebeck coefficient and resistivity measurements occurred when unexpected power outages occurred. The ratcheting experiments showed that these perturbations could be expected. The recovery time for the unsegmented element was more rapid than the segmented element.

A ring bulge above the iron interface of the segmented element, developed during the first few hours of current operation, did not enlarge since its first appearance. A swelling in the lower $25 \%$ of the unsegmented element also appeared in the first few hours of high-current testing. This swelling also did not increase in the last 600 test hours. These swollen zones are due to transport of copper and stainless-steel hot cap materials through the $(\mathrm{Cu}, \mathrm{Ag})_{2} \mathrm{Se}$.

Ratcheting observed at lower iL/A values in segmented sample 6875-132-36 did not occur during the life test of this element. Ratcheting was observed in the unsegmented element at an iL/A value of 9.58 at the beginning of testing. It was still observed 600 test hours later. The ratchet cycle frequency of element $6875-151-1 \mathrm{~B}$ was irregular and increased during the life tests.

8236-4-1A. Element 8236-4-1A was shut down when the test stand developed an air leak. The test was terminated after visual examination of the element showed that the element had been damaged by the air exposure. Seebeck coefficient and resistivity remained reasonably stable for the $\geq 1400$ test hours, as shown in Figs. 2-44 and 2-45. The shape and frequency of ramping of the output voltage changed during the test, but the amplitude of this ramping remained approximately the same. The shape and frequency of the open circuit voltage ramping of the $(\mathrm{Cu}, \mathrm{Ag})_{2} \mathrm{Se}$ changed with time. The dwell time in the high ramping mode decreased with time. The amplitude of the ramping apparentiy decreased with time.

8236-3-1B. The components of this segmented P-type element are $(\mathrm{Cu}, \mathrm{Ag})_{2} \mathrm{Se}$ upper segment with a W-26/Re wire-mesh-to-hot-cap joint. The hot cap was made from a $0.058-\mathrm{cm}$-thick Mo-Re sheet. The element was sequentially hot pressed with iron powder and a lower segment of $(\mathrm{Bi}, \mathrm{Sb})_{2} \mathrm{Te}_{3}$. The iron formed a $0.075-\mathrm{cm}$ barrier between the two segments to prevent copper diffusion into the $(\mathrm{Bi}, \mathrm{Sb})_{2} \mathrm{Te}_{3}$. The cold side was also covered with $0.048-\mathrm{cm}$ iron to ensure cold-side thermal heat transfer and electrical contact integrity. Electrodes were attached to the hot and cold caps and the iron barrier between the upper and lower thermoelectric segments. The hot side of the element was heated to $750^{\circ} \mathrm{C}$ without thermal barriers for $101 \mathrm{~h}$ with 0 to $0.694 \mathrm{~A}$ current flows for initial diagnostics on the element. The current was increased to $1.288 \mathrm{~A}$, which corresponds to an $\mathrm{iL} / \mathrm{A}$ value of 7.4 through the $(\mathrm{Cu}, \mathrm{Ag})_{2} \mathrm{Se}$ segment of the element. The element was then life tested for $6356 \mathrm{~h}$ in a nominal $755^{\circ} \mathrm{C} / 230^{\circ} \mathrm{C} / 160^{\circ} \mathrm{C}$ thermal gradient in vacuo. The external appearance of the element remained essentially the same for the last 6000 test hours. During the first 300 test hours, a small collar developed just above the iron barrier. This collar did not enlarge during the remainder of the test.

Plant power loss caused three test interruptions at 1437, 2876, and 5899 test hours. The test element went to room temperature each time. Figures 2-51 through 2-53 show that the major effect on the Seebeck coefficient and resistivity occurred during the first cooldown at 1437 test hours. The thermoelectric behavior of this element was reasonably stable for the last 4900 test hours; this was in spite of not providing a vapor suppression system. 


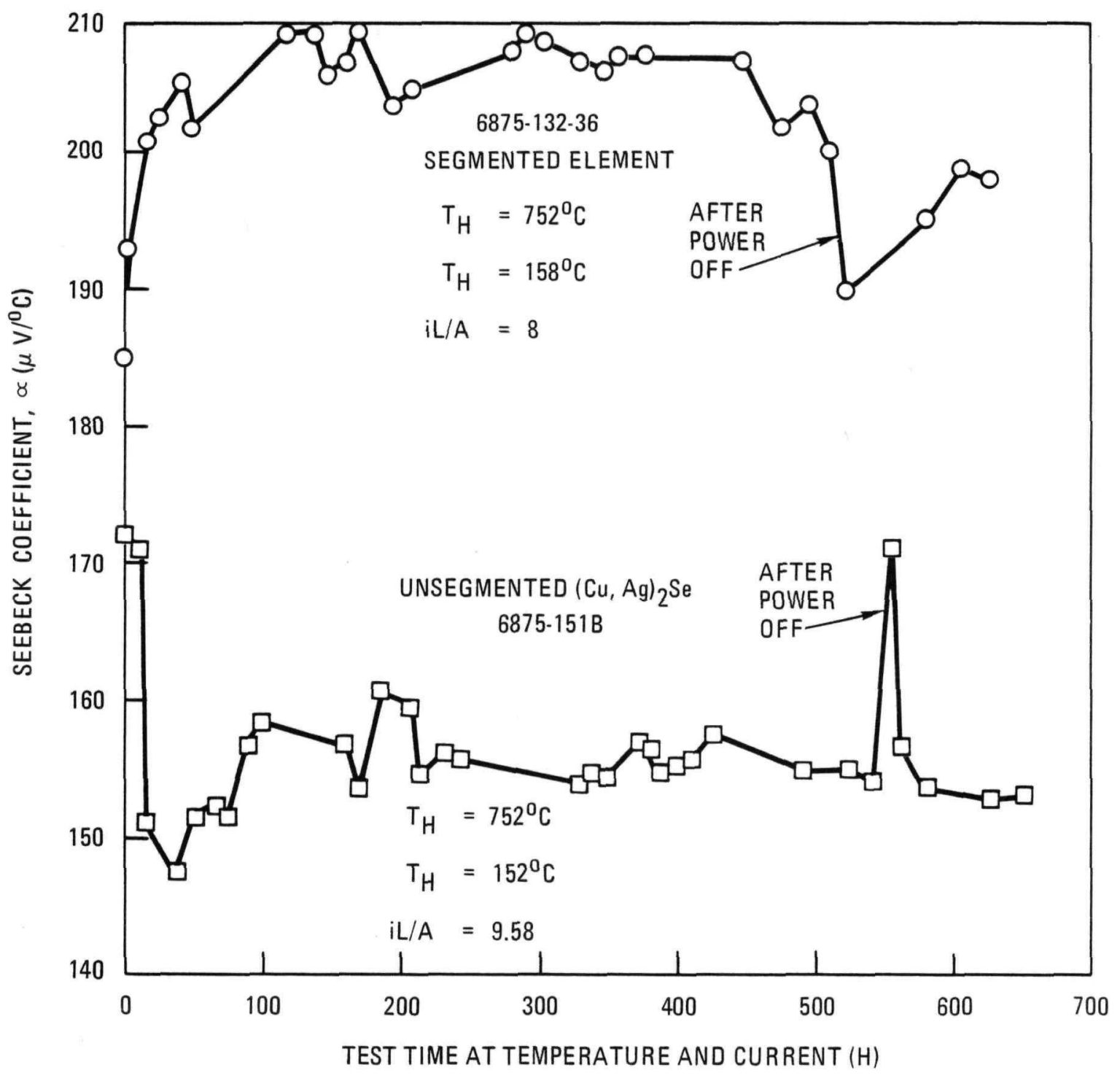

Fig. 2-49. Seebeck coefficients of P-type elements 6875-132-36 and 6825-151B 


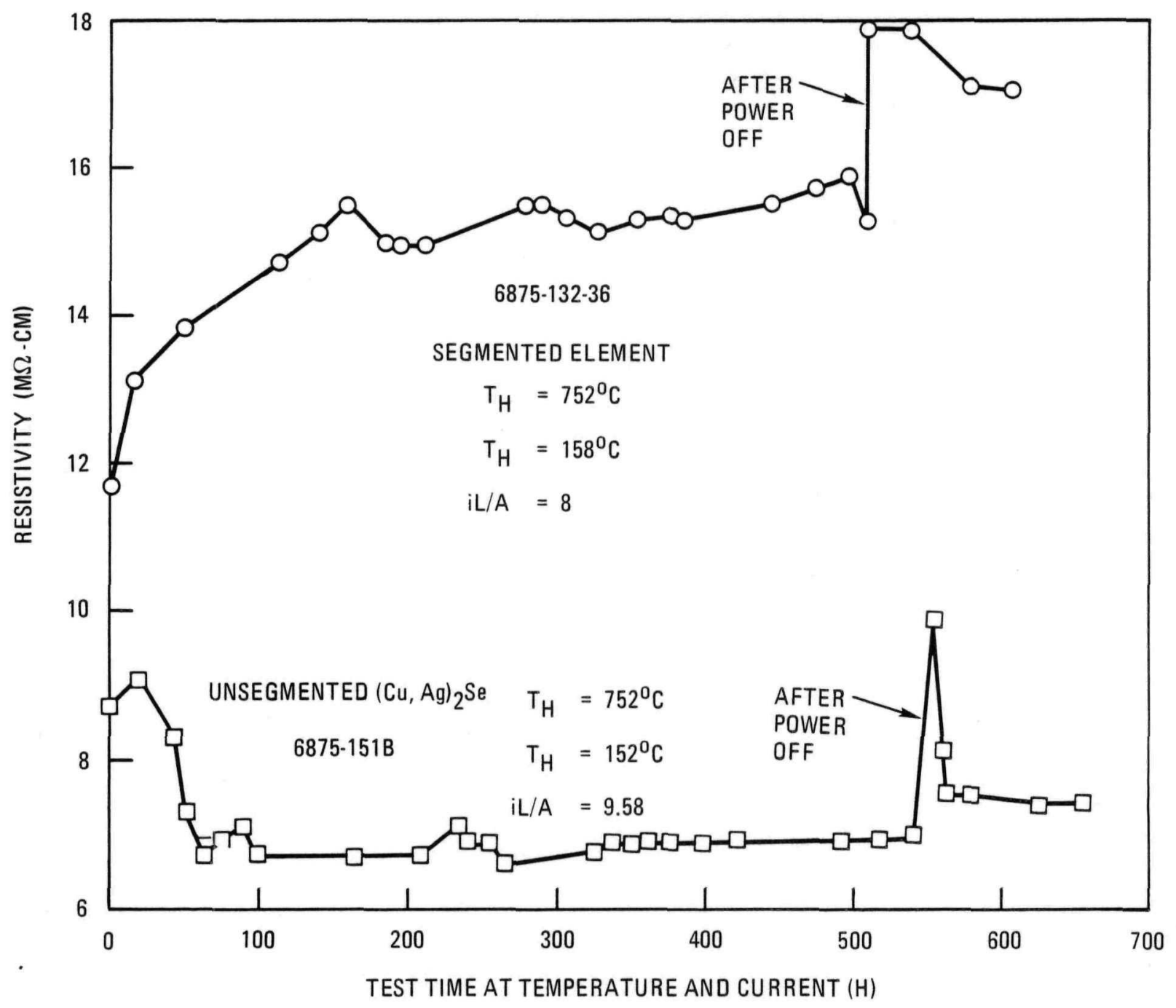

Fig. 2-50. Resistivity values of P-type elements 6875-132-36 and 6875-151B 


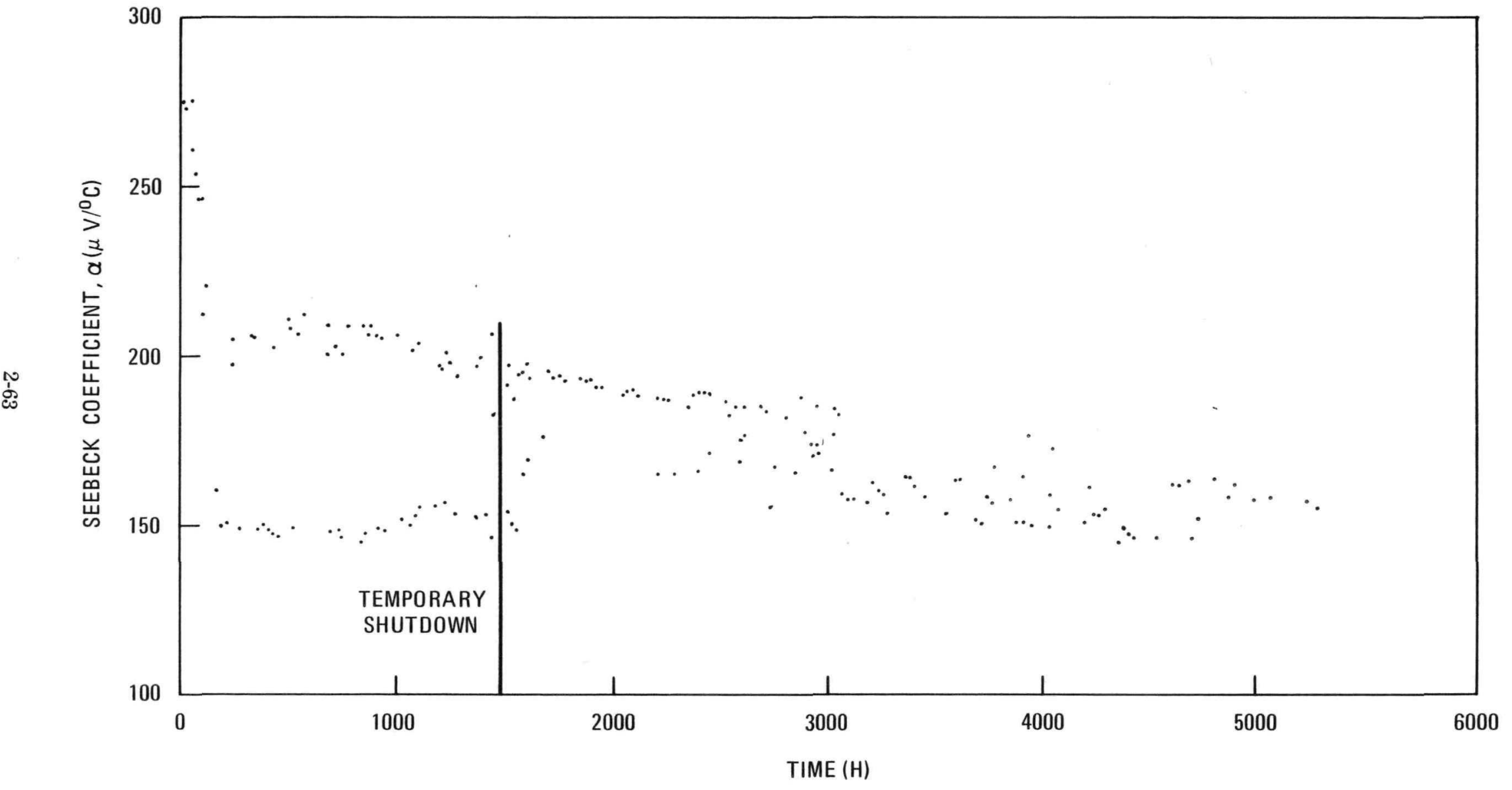

Fig. 2-51. Seebeck coefficients of the $(\mathrm{Cu}, \mathrm{Ag})_{2}$ Se segment of P-type element 8236-3-1B tested in a thermal gradient of $755^{\circ} \mathrm{C} / 220^{\circ} \mathrm{C}$ 


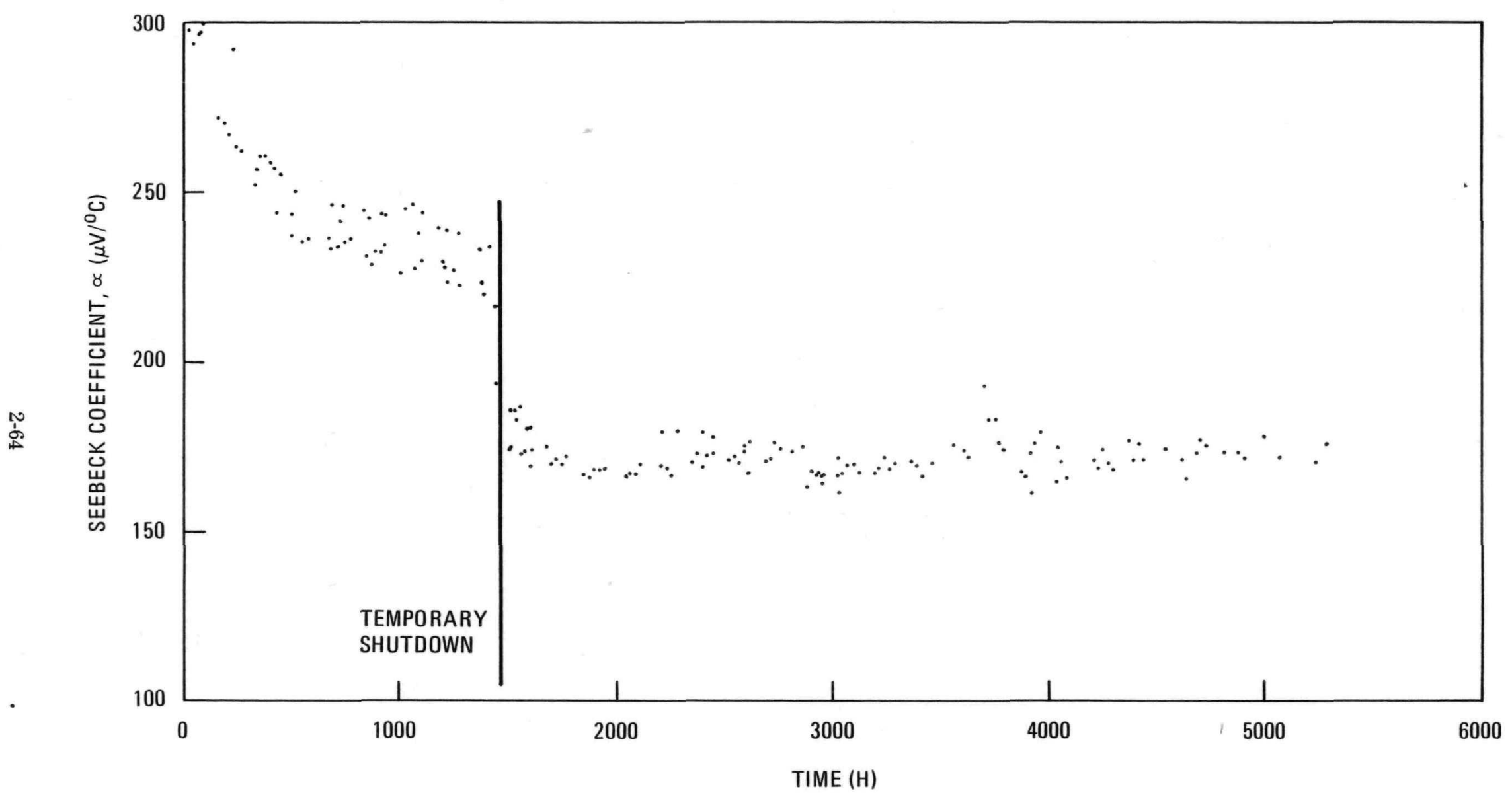

Fig. 2-52. Seebeck coefficients of the $(B i, S b)_{2} T_{3}$ segment of P-type element 8236-3-1B tested in a thermal gradient of $220^{\circ} \mathrm{C} / 160^{\circ} \mathrm{C}$ 


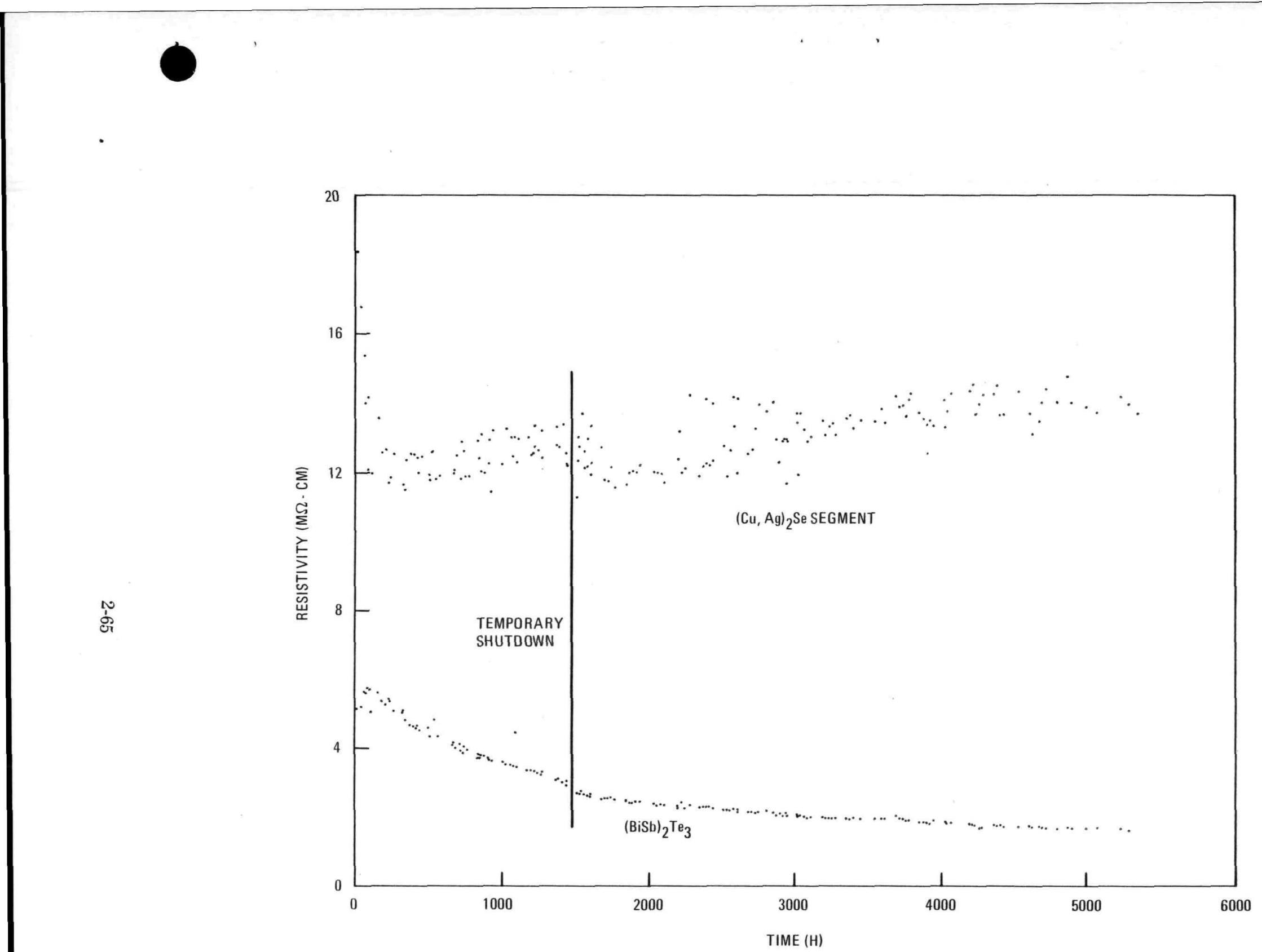

Fig. 2-53. Resistivity values of segmented P-type element 8236-3-1B tested in a thermal gradient of $755^{\circ} \mathrm{C} / 220^{\circ} \mathrm{C} / 160^{\circ} \mathrm{C}$ 
8236-10. To eliminate the possibility that the weighted hot cap is the reason that contact is being maintained with the element, a new segmented P-type element test, 823610 , was begun. This element had no contact with the heater; instead, it was radiationcoupled to the heat source. It also had a quartz vapor suppression sleeve which was held in place by a welded Mo-50/Re collar. Molybdenum-specified paper washers were placed around the element for additional insulation, making the element very much like those for couples and modules. The element was fabricated with a W-26/Re wire mesh diffusionbonded to the inside surface of the Mo-50/Re hot cap to form the element hot-cap joint. Figures 2-54 and 2-55 show Seebeck coefficient and resistivity measurements during the test. The values reported are for the overall element and only indirectly reflect performances of individual $(\mathrm{Cu}, \mathrm{Ag})_{2} \mathrm{Se}$ and $(\mathrm{Bi}, \mathrm{Sb})_{2} \mathrm{Te}$ segments. The test element was cooled to room temperature for $30 \mathrm{~h}$ following a power shutdown. Resistivity and Seebeck coefficient measurements before and after the power loss were approximately the same. 


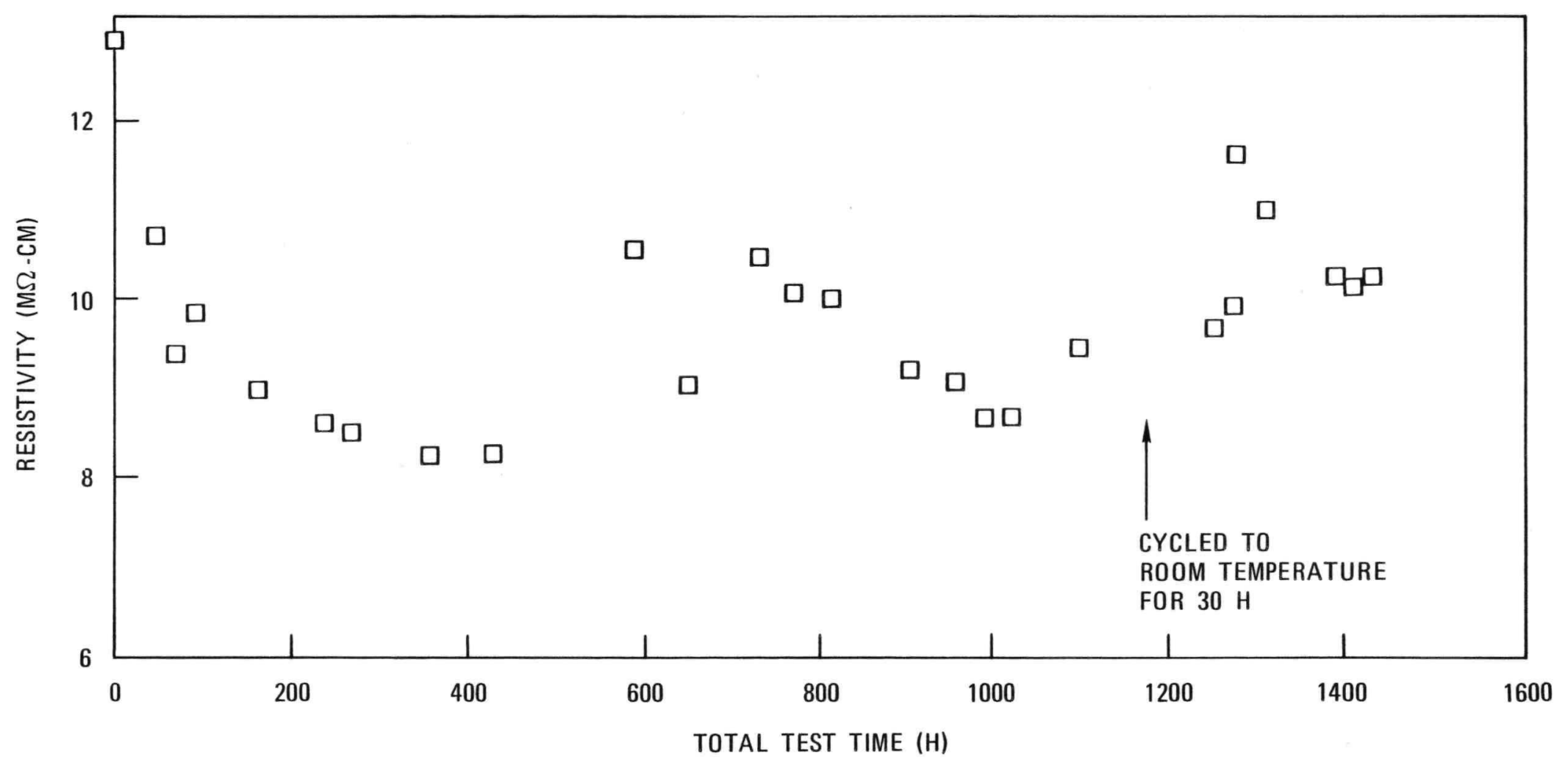

Fig. 2-54. Resistivity values of segmented P-type element 8236-10 tested in a thermal gradient of $695^{\circ} \mathrm{C} / 45^{\circ} \mathrm{C}$ 


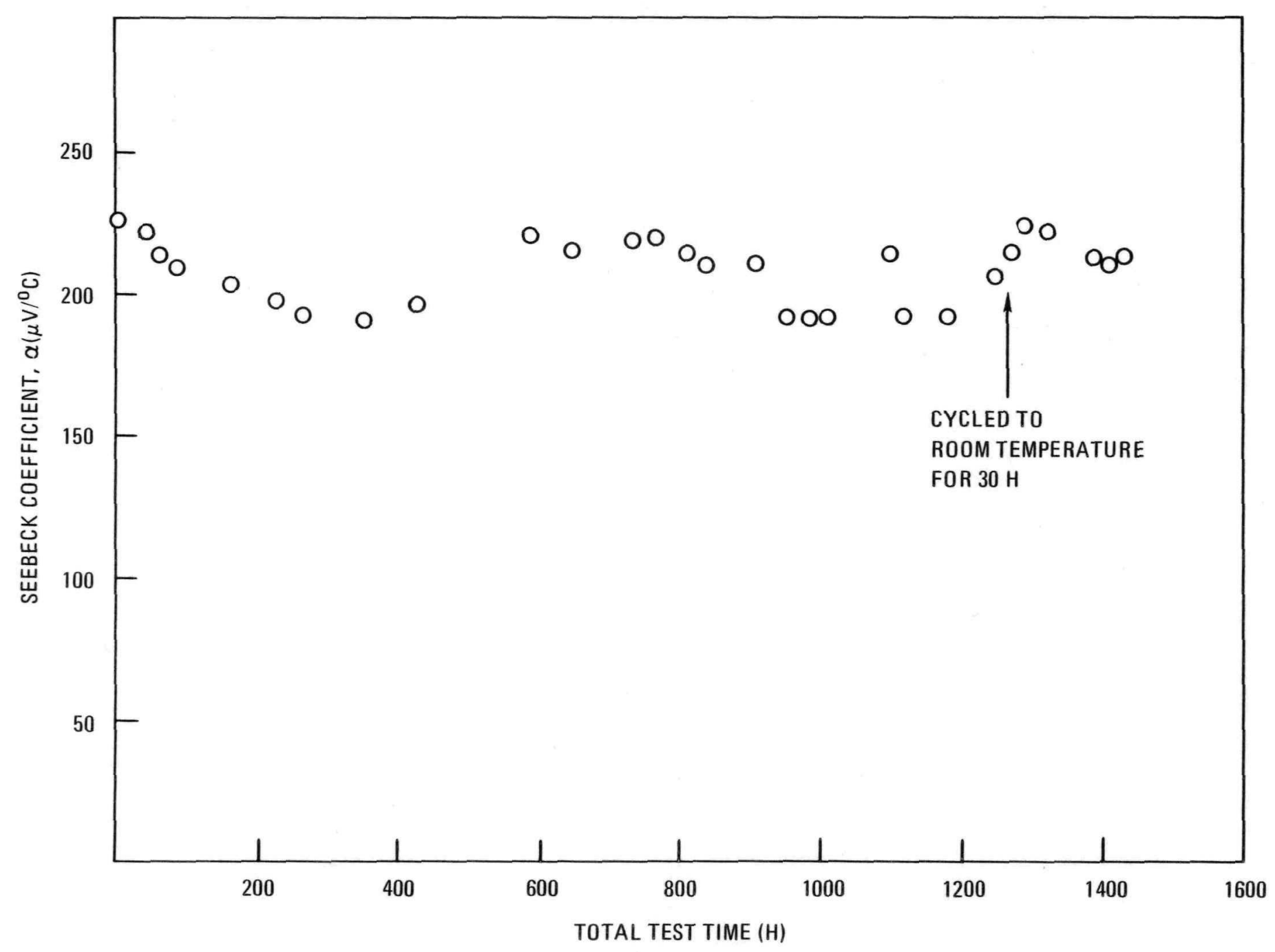

Fig. 2-55. Seebeck coefficients for segmented P-type element 8236-10 tested in a thermal gradient of $695^{\circ} \mathrm{C} / 45^{\circ} \mathrm{C}$ 


\section{SEGMENTED N-ELEMENT DEVELOPMENT}

Early segmented N-element studies emphasize the development of $\mathrm{Gd}_{2} \mathrm{Se}_{3}$ as the high-temperature component of the segmented N-type element. Phase instability at proposed operating temperatures was found to be a more difficult problem than originally thought. Alternative materials were sought as possible solutions to the phase instability problem. $\mathrm{Nd}_{2} \mathrm{Se}_{3}$ was reported to have approximately the same thermoelectric properties as $\mathrm{Gd}_{2} \mathrm{Se}_{3}$ and only one crystal structure at target fabricating and operating temperatures. $\mathrm{NdSe}_{1.5-x}$ was thus the primary material examined in this recent effort to develop segmented $\mathrm{N}$-type thermoelectric materials. This portion of the program was in three parts:

1. Evaluate processes to prepare $\mathrm{NdSe}_{1.5-\mathrm{x}}$ and control the $\mathrm{Nd} / \mathrm{Se}$ ratio.

2. Examine element fabrication processes, including investigate additives to aid in reducing the friability of $\mathrm{NdSe}_{1.5-x}$ elements.

3. Evaluate techniques to join the hot cap to $\mathrm{NdSe}_{\mathrm{x}}$.

\subsection{PREPARATION OF NdSe $\mathrm{N}_{1.5-\mathrm{x}}$}

Both GA and Ames Laboratory prepared $\mathrm{NdSe}_{1.5-x}$ samples. The results from examinations of materials from both organizations are reported below.

\subsubsection{Processes Evaluated}

3.1.1.1. Method 1: Control of Nd/Se Ratio by Controlling the Starting Alloy Composition. Tables 3-1 and 3-2 show the critical features of the processes of GA and Ames Laboratory to prepare $\mathrm{NdSe}_{1.5-\mathrm{x}}$ by controlling the starting alloy composition and physical form. Table 3-3 shows the results from three of the GA Method $1 \mathrm{Nd}_{2} \mathrm{Se}_{3}$ alloys. The heat treatment schedules involved heating the elemental ingredients to $1050^{\circ} \mathrm{C}$ followed by an extended exposure at $1050^{\circ} \mathrm{C}$ and melting in a sealed graphite crucible. As shown in Table 3-3, melting resulted in significant losses of selenium, although a homogeneous cubic product was obtained. This cubic product is believed to be $\mathrm{Nd}_{3} \mathrm{Se}_{4}$. Homogenization of the alloy at $1600^{\circ} \mathrm{C}$ in a sealed graphite crucible rather than melting (row 3, Table $3-3)$ resulted in much lower selenium losses, although the product was a mixture of two cubic phases.

The process was modified to try to inhibit selenium loss. This involved heating of the elemental ingredients in evacuated quartz vials to approximately $1000^{\circ} \mathrm{C}$ and holding them at temperature long enough for complete reaction (approximately $100 \mathrm{~h}$ ). During heating, the vials were held at intermediate temperatures (approximately $450^{\circ}$ and $750^{\circ} \mathrm{C}$ ) overnight to avoid excessive pressure buildup in the vials. Although the processing schedule is cumbersome, material suitable for hot pressing was obtained. The reaction product was not homogeneous, but was completely reacted (i.e., no elemental neodymium was present). The reaction product was mechanically homogenized by grinding and mixing to provide powder for hot pressing. 


\title{
TABLE 3-1
}

\section{GA METHOD 1: NdSe $_{1.5}$ ALLOY DEVELOPMENT THROUGH CONTROL OF STARTING ALLOY COMPOSITION}

\author{
Reaction of neodymium pellets and selenium powder \\ $\mathrm{T}=1045^{\circ} \mathrm{C}$ at rate $<150^{\circ} \mathrm{C} / \mathrm{h}$ (melting point of neodymium is $1019^{\circ} \mathrm{C}$ ) \\ Hold $100 \mathrm{~h}$ minimum \\ Use finely divided neodymium \\ Homogenization to $\approx 1600^{\circ} \mathrm{C} / 15 \mathrm{~min}$ (optional) \\ Crush and grind product to $\approx-60$ mesh \\ Add $1 \%$ nickel $\approx-270$ mesh and blend \\ Vacuum hot press
}

TABLE 3-2

\section{NdSe $_{1.5}$ ALLOY DEVELOPMENT, AMES LABORATORY TECHNIQUES FOR NdSe ${ }_{1.5}$ PRODUCTION}

\section{Method 1}

React neodymium thin sheets with selenium powder (processing sequence similar to GA)

Process starts with desired composition

\section{Method 2 Diselenide Process}

Same as Method 1 but produces $\mathrm{NdSe}_{2}$ as an intermediate compound

Thermal decomposition of $\mathrm{NdSe}_{2}$ (selenium distillation) to produce desired $\mathrm{NdSe}_{\mathrm{x}}$ alloy

$$
\mathrm{NdSe}_{2} \stackrel{1100^{\circ} \mathrm{C}}{\longrightarrow} \mathrm{NdSe}_{1.5}+\mathrm{Se}_{2} \uparrow
$$

TABLE 3-3

GA METHOD $1 \mathrm{Nd}_{2} \mathrm{Se}_{3}$ ALLOY DEVELOPMENT

\begin{tabular}{|c|c|c|c|c|}
\hline $\begin{array}{l}\text { Original } \\
\text { Chemistry }\end{array}$ & $\begin{array}{c}\text { Heating } \\
\text { Schedule }^{(a)}\end{array}$ & $\begin{array}{c}\text { Final } \\
\text { Chemistry }\end{array}$ & $\begin{array}{l}\text { Crystal } \\
\text { Structure }\end{array}$ & Comments \\
\hline $\mathrm{NdSe}_{1.50}$ & A B D & $\mathrm{NdSe}_{1.36}$ & Cubic & $\begin{array}{l}\text { Measured lattice parameter } \\
8.864 \mathrm{~A} \text { versus } 8.659 \mathrm{~A} \\
\text { literature value for } \mathrm{Nd}_{3} \mathrm{Se}_{4}\end{array}$ \\
\hline $\mathrm{NdSe}_{1.49}$ & A D & $\mathrm{NdSe}_{1.39}$ & Cubic & - \\
\hline $\mathrm{NdSe}_{1.48}$ & A C E & $\mathrm{NdSe}_{1.46}$ & $\begin{array}{l}\text { Cubic (two } \\
\text { phase) }\end{array}$ & $\begin{array}{l}\text { Mixture sequence versus } \\
\text { second monoselenides }\end{array}$ \\
\hline
\end{tabular}

${ }^{\text {(a) }} \mathrm{A}=$ Room temperature to $1050^{\circ} \mathrm{C}$ at $15^{\circ} \mathrm{C} / \mathrm{h}$.

$\mathrm{B}=168 \mathrm{~h}$ at $1050^{\circ} \mathrm{C}$.

$\mathrm{C}=96 \mathrm{~h}$ at $1050^{\circ} \mathrm{C}$.

$\mathrm{D}=$ Melted at $1700^{\circ} \mathrm{C}$.

$\mathrm{E}=1 \mathrm{~h}$ at $1500^{\circ} \mathrm{C}$. 
Vacuum hot pressing trials were conducted on three $\mathrm{NdSe}_{1.5-\mathrm{x}}$ alloys produced by GA and Ames Laboratory. Hot pressing was performed in graphite dies at $1575^{\circ} \mathrm{C}$ and $34.5 \mathrm{MPa}(5000 \mathrm{psi})$ for $10 \mathrm{~min}$. In each case, the hot pressed pellets were dense but quite friable. Table 3-4 shows the results of these trials.

3.1.1.2. Method 2: $\mathbf{N d S e}_{1.5-\mathrm{x}}$ by $\boldsymbol{N d S e}_{2}$ Diselenization. Batches of $\mathrm{NdSe}_{1.5-x}$ prepared by Ames Laboratory by their diselenide method (Table 3-2) were examined. The material had a more homogeneous appearance than batches prepared by other processes. Thermal gravimetric analysis showed the composition of one batch to be $\mathrm{NdSe}_{1.495}+0.005$. X-ray examination of this sample showed only the presence of cubic $\mathrm{Nd}_{2} \mathrm{Se}_{3}$. This material was melted for further homogenization. Three gram batches of melted $\mathrm{NdSe}_{1.5-x}$ were prepared. Table 3-5 summarizes these and other melting trials. Very little $\mathrm{Se}_{2}$ was lost after these melt runs. Cubic $\mathrm{Nd}_{2} \mathrm{Se}_{3}$ remained the only detectable phase, and the $\mathrm{Se} / \mathrm{Nd}$ ratio did not drop below 1.45. Although the quantitative, laboratory measured distinctions between these melted samples were small, the samples had qualitative, visual differences. The unmelted starting $\mathrm{Nd}_{2} \mathrm{Se}_{3}$ from Ames Laboratory was reddish with small black and yellow specks. The melted samples were black with brown zones. Some samples melted at lower power settings had a small number of translucent red crystals.

Figure 3-1 shows the GA process steps which are now being designated as standard. Process steps used by $3 \mathrm{M}$ Company are shown for comparison. The two processes differ in the steps to produce $\mathrm{NdSe}_{1.5-\mathrm{x}}$. In the $3 \mathrm{M}$ Company process, the $\mathrm{Se} / \mathrm{Nd}$ formula weight ratio of the starting material is 1.5. Selenium losses from each of the four major process steps determines the final $\mathrm{Se} / \mathrm{Nd}$ ratio. Controlling the loss in selenium requires very careful weighing and geometry control of the starting materials and a certainty that all conversion processes are complete. Any variation in the reproducibility of the steps in the preparation results in a variation in the final $\mathrm{NdSe}_{1.5-\mathrm{x}}$ composition.

The GA process is a slight modification of the Ames Laboratory diselenide process. Excess selenium is mixed with neodymium in the initial conversion to make $\mathrm{NdSe}_{2}$. The $\mathrm{NdSe}_{2}$ is then decomposed into $\mathrm{Nd}_{2} \mathrm{Se}_{3}$ and selenium at $1050^{\circ} \mathrm{C} . \mathrm{NdSe}_{2}$ is again formed by heating $\mathrm{Nd}_{2} \mathrm{Se}_{3}$ with selenium at $650^{\circ} \mathrm{C}$. Once formed, the final $\mathrm{NdSe}_{1.5-\mathrm{x}}$ composition is controlled by holding $\mathrm{Nd}_{2} \mathrm{Se}_{3}$ at its melting point. In this way, the final melting step is critical to the $\mathrm{Se} / \mathrm{Nd}$ ratio. The $\mathrm{Nd}_{2} \mathrm{Se}_{3}$ vapor pressure measurements evidence this.

\subsection{2. $\quad \mathrm{NdSe}_{1.5-\mathrm{x}}$ Process Controls}

Table 3-6 gives the process controls used in preparing $\mathrm{NdSe}_{1.5-x}$. The appearance uniformity, composition, and thermoelectric property measurements determine the final acceptance or rejection of an $\mathrm{NdSe}_{1.5-\mathrm{x}}$ batch. The melting trial results (Table 3-5) show that the processes of Ames Laboratory and GA produce materials with no significant difference in $\mathrm{Se} / \mathrm{Nd}$ ratios or Seebeck coefficients. It also shows that melting $\mathrm{NdSe}_{1.5-\mathrm{x}}$ with or without a crucible lid had no apparent effect on the final product. Red phases were observed in melted samples briefly held at the melting points. These phases disappeared when the melt was held for $10 \mathrm{~min}$ or more at melting temperature. 


\section{TABLE 3-4}

METHOD $1 \mathbf{N d}_{2} \mathrm{Se}_{3}$ ALLOY DEVELOPMENT EVALUATION

\begin{tabular}{|c|c|c|c|}
\hline Alloy & Producer & $\begin{array}{c}\text { Structure of } \\
\text { Starting Material }\end{array}$ & $\begin{array}{c}\text { Room Temperature } \\
\text { Seebeck Coefficient, } \alpha \\
\text { After Hot Pressing } \\
\left(\mu \mathrm{V} /{ }^{\circ} \mathrm{C}\right)\end{array}$ \\
\hline $\begin{array}{l}\mathrm{NdSe}_{1.46} \\
\mathrm{NdSe}_{1.49} \\
\mathrm{NdSe}_{1.50}\end{array}$ & $\begin{array}{l}\text { GA } \\
\text { Ames Laboratory } \\
\text { Ames Laboratory }\end{array}$ & $\begin{array}{l}\text { Cubic (two phase) } \\
\text { Cubic } \\
\text { Cubic }\end{array}$ & $\begin{array}{l}-40.1 \\
-142.0 \\
-136.1\end{array}$ \\
\hline
\end{tabular}


TABLE 3-5

$\mathrm{Nd}_{2} \mathrm{Se}_{3}$ MELTING TRIALS

\begin{tabular}{|c|c|c|c|c|c|c|c|c|}
\hline & Batch No. & Additives & Melt Gas & $\begin{array}{c}\text { Observed } \\
\text { Temp } \\
\left({ }^{\circ} \mathrm{C}\right)\end{array}$ & $\begin{array}{l}\text { Melt Time } \\
\text { at Temp } \\
(\min )\end{array}$ & $\mathrm{Se} / \mathrm{Nd}$ & $\begin{array}{c}\mathbf{T}=80^{\circ} \mathbf{C} \\
\text { Seebeck } \\
\text { Coefficient, } \alpha \\
\left(\mu \mathrm{V} /{ }^{\circ} \mathbf{C}\right)\end{array}$ & Notes \\
\hline & $7958-56$ & 0 & 0 & - & - & $1.495 \pm 0.005$ & $\mathrm{ND}^{(\mathrm{a})}$ & $\begin{array}{l}\text { Ames Laboratory } \\
\mathrm{Nd}_{2} \mathrm{Se}_{3}\end{array}$ \\
\hline & $7958-57$ & 0 & $\mathrm{He}$ & -1770 & $\begin{array}{l}4 \text { at } 1600,2 \text { at } \\
1850\end{array}$ & 1.45 & -70 & $\begin{array}{l}\text { Reduce pressure } \\
\text { melt ( } 2 \text { tries) }\end{array}$ \\
\hline & $7958-58-1$ & 0 & $\mathrm{Ar}$ & 1725 & 1.0 & 1.50 & -127 & \\
\hline & $7958-58-2$ & 0 & $\mathrm{Ar}$ & 1740 & 1.0 & 1.49 & -124 & \\
\hline & 7958-58-3 & 0 & $\mathrm{Ar}$ & 1750 & 1.5 & 1.50 & -120 & \\
\hline & $7958-65-1$ & Se $1 \%$ & $\mathrm{Ar}$ & 1745 & 2.0 & 1.49 & -125 & \\
\hline & $7958-65-2$ & $\begin{array}{l}\text { Se } 1 \%, \\
\text { C } 0.1 \%\end{array}$ & $\mathrm{Ar}$ & 1750 & 2.0 & 1.48 & -124 & \\
\hline 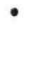 & $7958-63-2$ & 0 & Ar & 1750 & 1.5 & 1.498 & -133 & GA $\mathrm{Nd}_{2} \mathrm{Se}_{3}$ \\
\hline & $7958-71-1$ & 0 & Ar & 1850 & $\begin{array}{l}\text { Ames Laboratory } \\
\text { material melted } \\
\text { at Ames }\end{array}$ & 1.487 & -94.8 & $\begin{array}{l}\text { Ames Laboratory } \\
\mathrm{Nd}_{2} \mathrm{Se}_{3}\end{array}$ \\
\hline & $7958-78-1$ & 0 & Ar & 1750 & 1.5 & 1.488 & -114 & $\mathrm{GA} \mathrm{Nd}_{2} \mathrm{Se}_{3}$ \\
\hline & $7958-90-1$ & 0 & $\mathrm{Ar}$ & -1800 & 3.0 & 1.494 & & \\
\hline & $7958-105 \mathrm{C}$ & 0 & Ar & -1800 & 10.0 & 1.482 & -101 & \\
\hline & 7958-105D & 0 & $\mathrm{He}$ & -1800 & 30.0 & 1.471 & -88.4 & \\
\hline
\end{tabular}

(a) Not determined. 


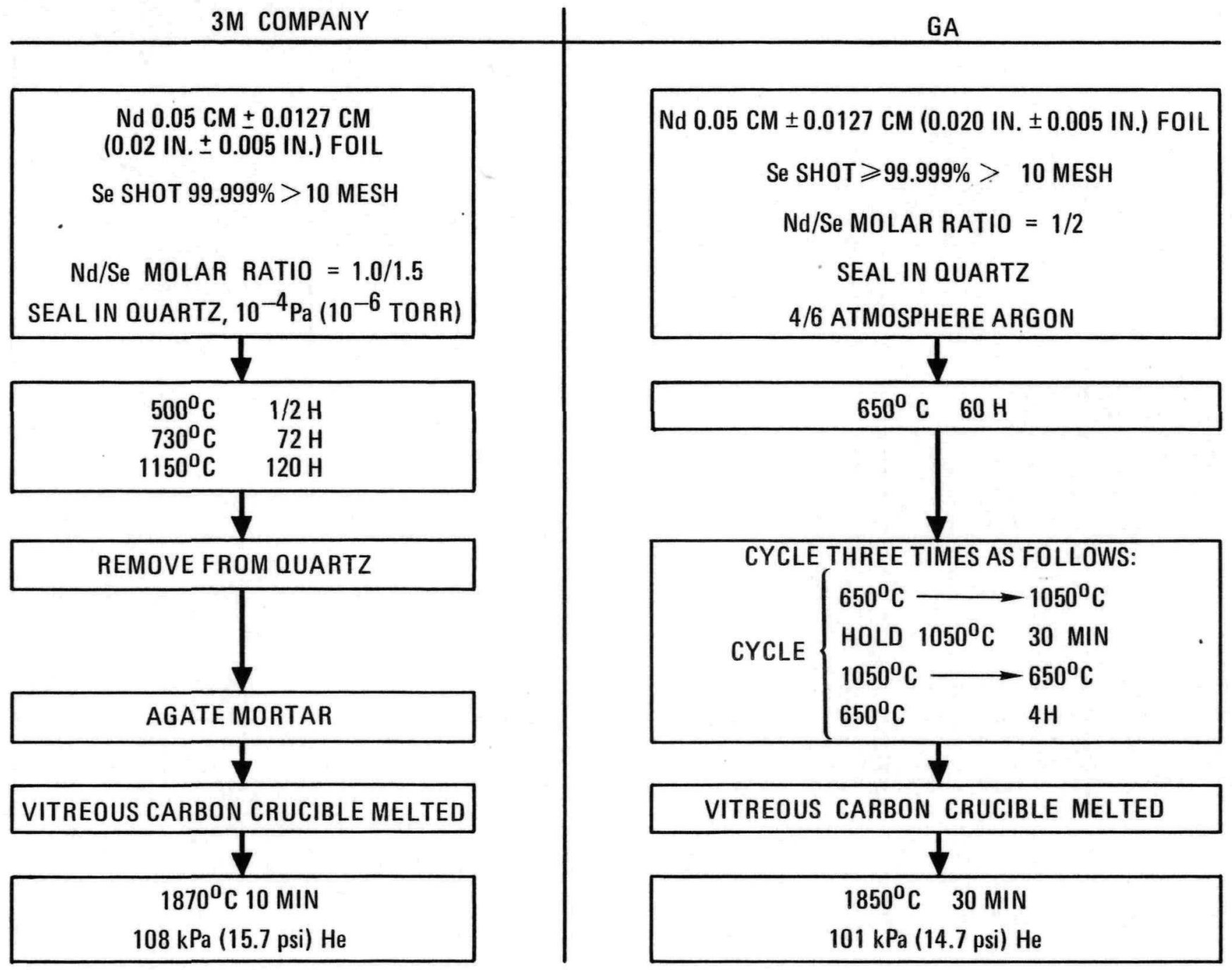

Fig. 3-1. Flowchart for preparation of $\mathrm{Nd}_{2} \mathrm{Se}_{3}$, 


\section{TABLE 3-6 \\ NdSe $_{1.5}$ PROCESS CONTROLS \\ Control}

Process

Neodymium and selenium starting materials

Heating of sealed off quartz vials

Reaction of neodymium and selenium after $1050^{\circ} \mathrm{C}$

treatment

$\mathrm{NdSe}_{-1.5}$ melting and cooling

$\mathrm{NdSe}_{-1.5}$ stoichiometry

measurement and structure

Grinding

Hot pressing
$99.999 \%$ pure neodymium and selenium. Selenium is purified at GA to reduce $\mathrm{O}_{2}$. $(99.999 \%$ pure material is not sold with respect to $\mathrm{O}_{2}$.)

Performed in inert atmosphere to minimize $\mathrm{O}_{2}$ diffusion through the quartz vials

Material is ground and visually inspected for unreacted neodymium via color differences and uniformity of grinding

Setup controlled to ensure repeatability

Seebeck coefficient on melted ingot chemical analyses via the several techniques discussed. Neutron activation analysis for $\mathrm{O}_{2}$ will be performed. X-ray diffraction. $\mathrm{Se}_{2}$ vapor pressure measurements.

Performed by hand to observe any inhomogeneities. All grinding performed in glove box.

Seebeck coefficient and resistivity of pressed element. Chemical analyses similar to above mechanical properties. 


\subsection{3. $\quad \mathbf{N d S e}_{1.5-\mathrm{x}}$ Property Measurements}

Table 3-7 summarizes the methods of determining the Se/Nd ratios. Neodymium content was determined from thermogravimetric apparatus (TGA) measurements. A wet chemistry ethylenedraminetetracacetic acid (EDTA) titration of $\mathrm{Nd}^{+3}$ is being used by Ames Laboratory for their Se/Nd ratio measurements. General Atomic did not evaluate the EDTA and $\mathrm{Na}_{2} \mathrm{~S}_{2} \mathrm{O}_{3}$ titration techniques because of the accuracy limitations of these measurements.

The most sensitive measure of the $\mathrm{Se} / \mathrm{Nd}$ ratio appears to be vapor pressure measurements. Figure 3-2 shows partial pressures of $\mathrm{Se}_{2}$ over several batches of melted and hot pressed $\mathrm{NdSe}_{1.5-\mathrm{x}}$ samples. Knudsen cells were used for these measurements in a mass spectrometer. The cell holes were calibrated by measuring silver signals from each, at the same temperature. The $\mathrm{Se}_{2}$ signals were corrected for the different hole sizes, using this information. The cells were tantalum tubes, closed at one end and lined with graphite foil. The temperatures were measured using a platinum versus $\mathrm{Pt} / 10 \% \mathrm{Rh}$ thermocouple attached to one of the tubes. The $\mathrm{Se}_{2}$, mass $160+$, was monitored as the cells were heated from room temperature. A very small amount of $\mathrm{Se}_{2}$ was observed from one sample between $240^{\circ}$ and $360^{\circ} \mathrm{C}$ for $\sim 10 \mathrm{~min}$. $\mathrm{Se}_{2}$ was again observed above $950^{\circ} \mathrm{C}$. The signal would go up as the temperature was raised, then go down very quickly. At $-1250^{\circ} \mathrm{C}$, $\mathrm{Se}_{2}$ was observed from samples. The $\mathrm{Se}_{2}$ from the cells reached a steady state at $1350^{\circ} \mathrm{C}$ after about $2 \mathrm{~h}$ of heating. Signal versus temperature data were then taken. The results show that the partial pressure of $\mathrm{Se}_{2}$ is strongly dependent on the total time that the $\mathrm{NdSe}_{1.5-\mathrm{x}}$ is held above $1700^{\circ} \mathrm{C}$. Whether this is during melting or post-hot-press annealing apparently does not matter. A comparison of $\mathrm{Se}_{2}$ partial pressures over samples which were examined as chunks and after powdering showed that powdering caused almost two orders of magnitude change in the measured vapor pressures. The surface of $\mathrm{Nd}_{2} \mathrm{Se}_{3}$ is sensitive to oxygen pickup. The surface-to-volume ratio of the chunks is small enough to make oxygen pickup insignificant. This is not true in powdered samples.

Figure 3-3 shows that the $\log$ of the $\mathrm{Se}_{2}$ partial pressure over $\mathrm{NdSe}_{1.5-\mathrm{x}}$ is related to $130^{\circ} \mathrm{C} / 30^{\circ} \mathrm{C}$ Seebeck coefficient measurements. These are, in turn, related to the $\log$ of the resistivity of the $\mathrm{NdSe}_{1.5-x}$ elements, as shown in Fig. 3-4. The partial pressures of $\mathrm{Se}_{2}$ over $\mathrm{NdSe}_{1.5-\mathrm{x}}$ solid solution were expected to undergo logarithmic changes with composition. This is what the Seebeck coefficient measurements suggest, but verification of this has not been made from chemical analyses. The figures show that control of the $\mathrm{NdSe}_{1.5-\mathrm{x}}$ thermoelectric properties of Seebeck coefficient and resistivity can be achieved by selective time-temperature annealing above $1700^{\circ} \mathrm{C}$. An effort was made to relate Se/ $\mathrm{Nd}$ ratios and Seebeck coefficients of $\mathrm{NdSe}_{1.5-\mathrm{x}}$ to process time at the melting temperature.

Figure 3-5 shows that both the Se/Nd ratios and the Seebeck coefficients are related to the process time at temperature. Vaporization loss of $\mathrm{Se}_{2}$ reduces the $\mathrm{Se} / \mathrm{Nd}$ ratio in the $\mathrm{NdSe}_{1.5-\mathrm{x}}$ solid solution. This, in turn, increases the doping and lowers the Seebeck coefficient. The results of experimental measurements (shown in Fig. 3-6), Seebeck coefficient, and the $\mathrm{Se} / \mathrm{Nd}$ ratios are linearly related. 


\section{TABLE 3-7}

\section{Nd/Se MEASUREMENTS}

Neodymium by TGA

$4 \mathrm{NdSe}_{\mathrm{x}}+3 \mathrm{O}_{2} \rightarrow \mathrm{Nd}_{2} \mathrm{O}_{3}+2 \mathrm{xSe}_{2} \uparrow$

$\mathrm{Nd} / \mathrm{Se}$ ratio calculated from $\mathrm{NdSe}_{\mathrm{x}}$ and $\mathrm{Nd}_{2} \mathrm{O}_{3}$ weight measurements

Limitations $= \pm 0.3 \%$ accuracy

Original material is assumed to be unoxidized

Neodymium by wet chemistry

EDTA titration of $\mathrm{Nd}^{+3}$ in a solution buffered to a $\mathrm{PH}$ of 5

Limitation $= \pm 0.5 \%$ accuracy

Selenium by wet chemistry

$\mathrm{Na}_{2} \mathrm{~S}_{2} \mathrm{O}_{3}$ titration in a $\mathrm{KI}$ starch solution

Limitation $= \pm 0.5 \%$ accuracy 


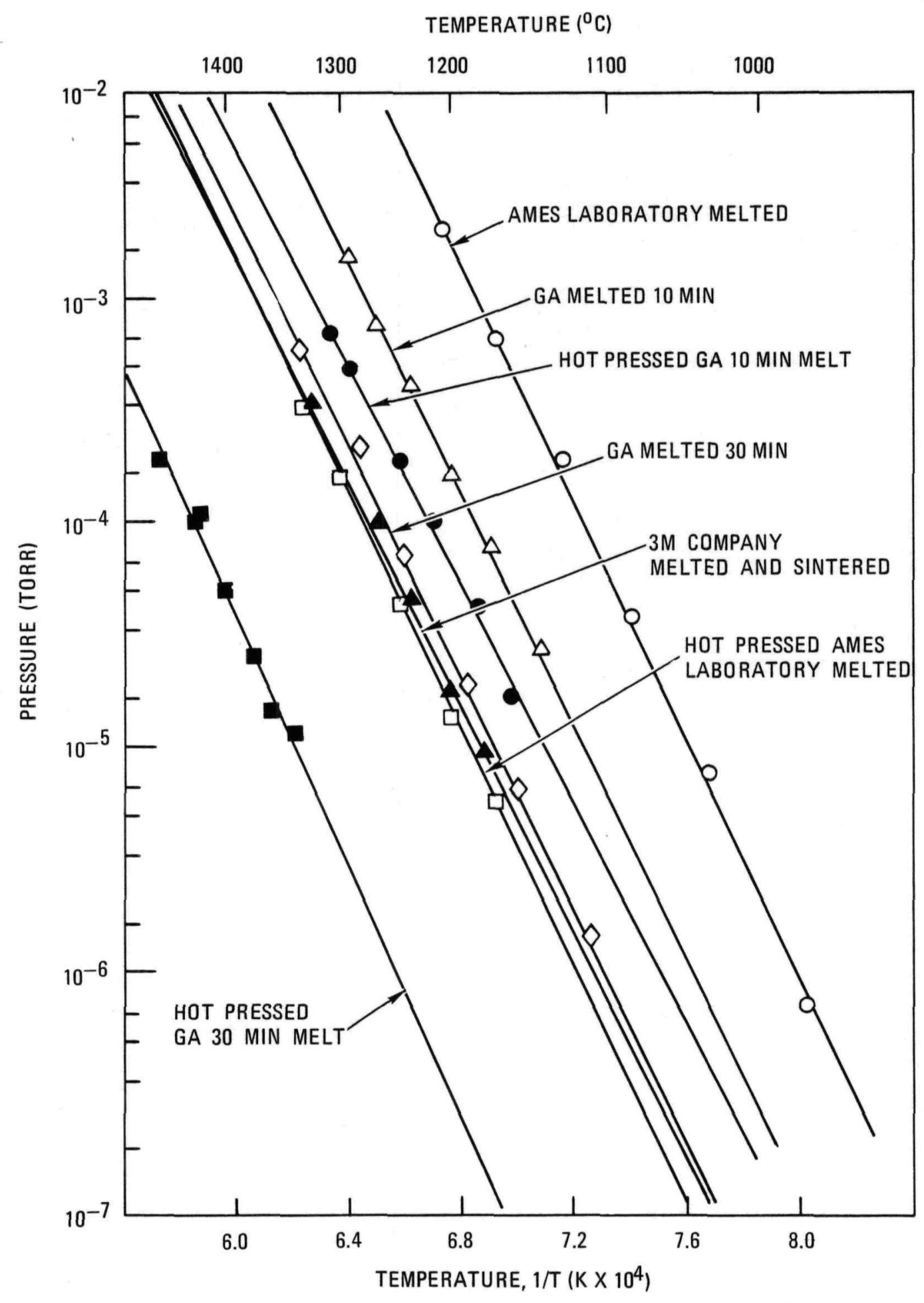

Fig. 3-2. Se.2 vapor pressure over various $\mathrm{NdSe}_{\mathrm{x}}$ chunks 


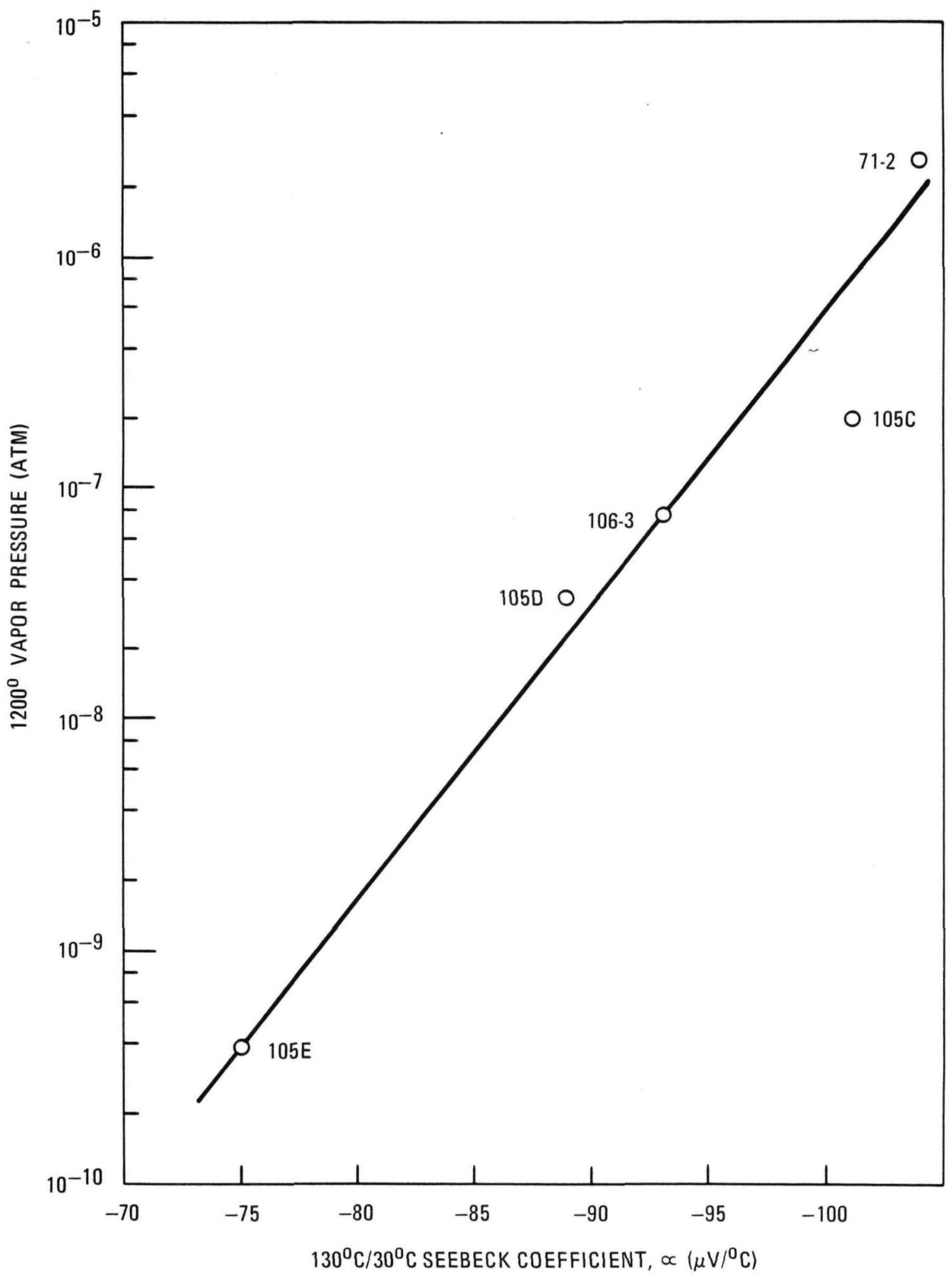

Fig. 3-3. Low-temperature Seebeck coefficient versus $1200^{\circ} \mathrm{C} \mathrm{Se}_{2.2}$ vapor pressure for $\mathrm{Nd}$..Se:; 


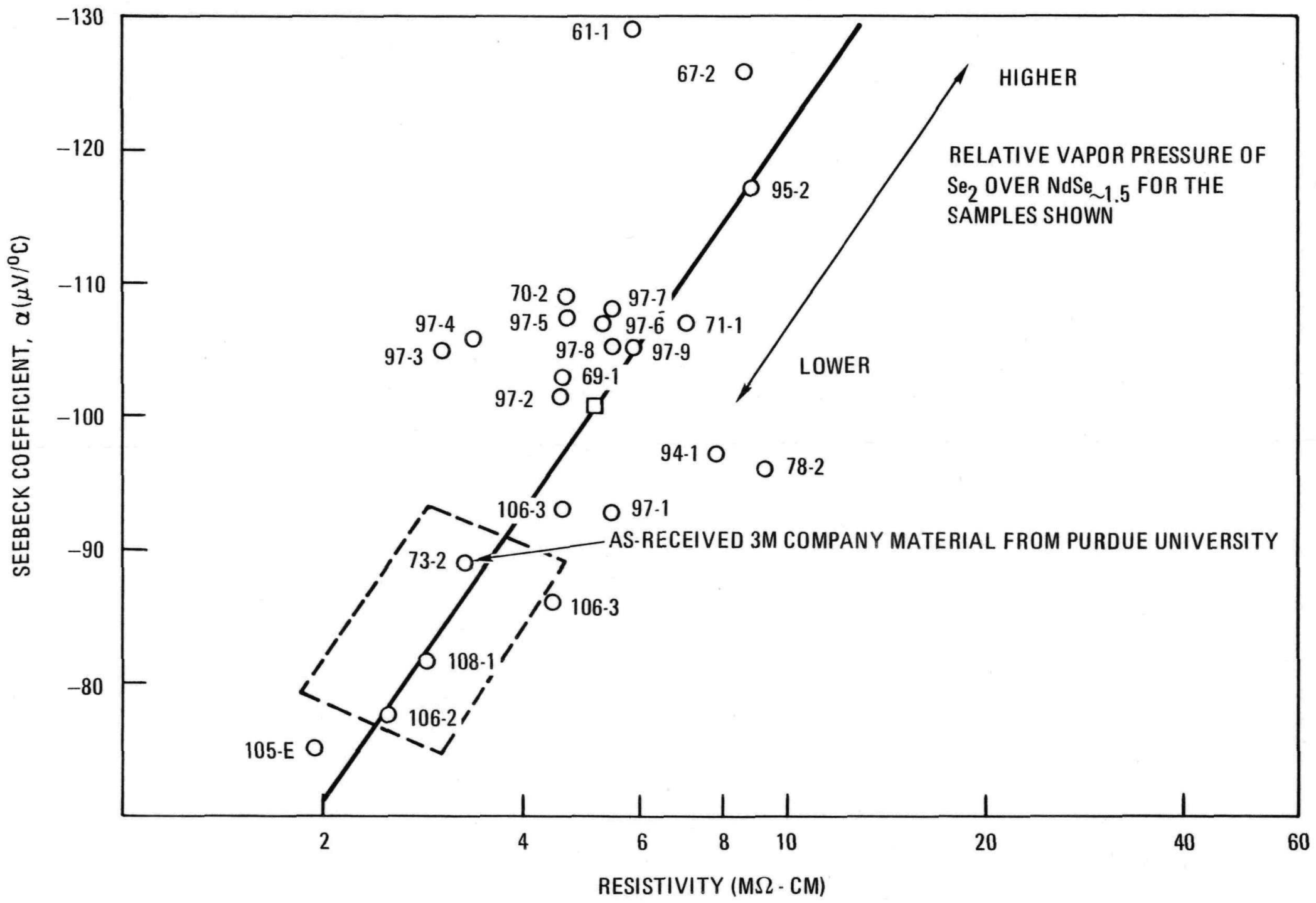

Fig. 3-4. As-fabricated low-temperature Seebeck coefficient versus resistivity for $\mathrm{Nd}_{2} \mathrm{Se} \mathrm{e}_{3}$ elements 


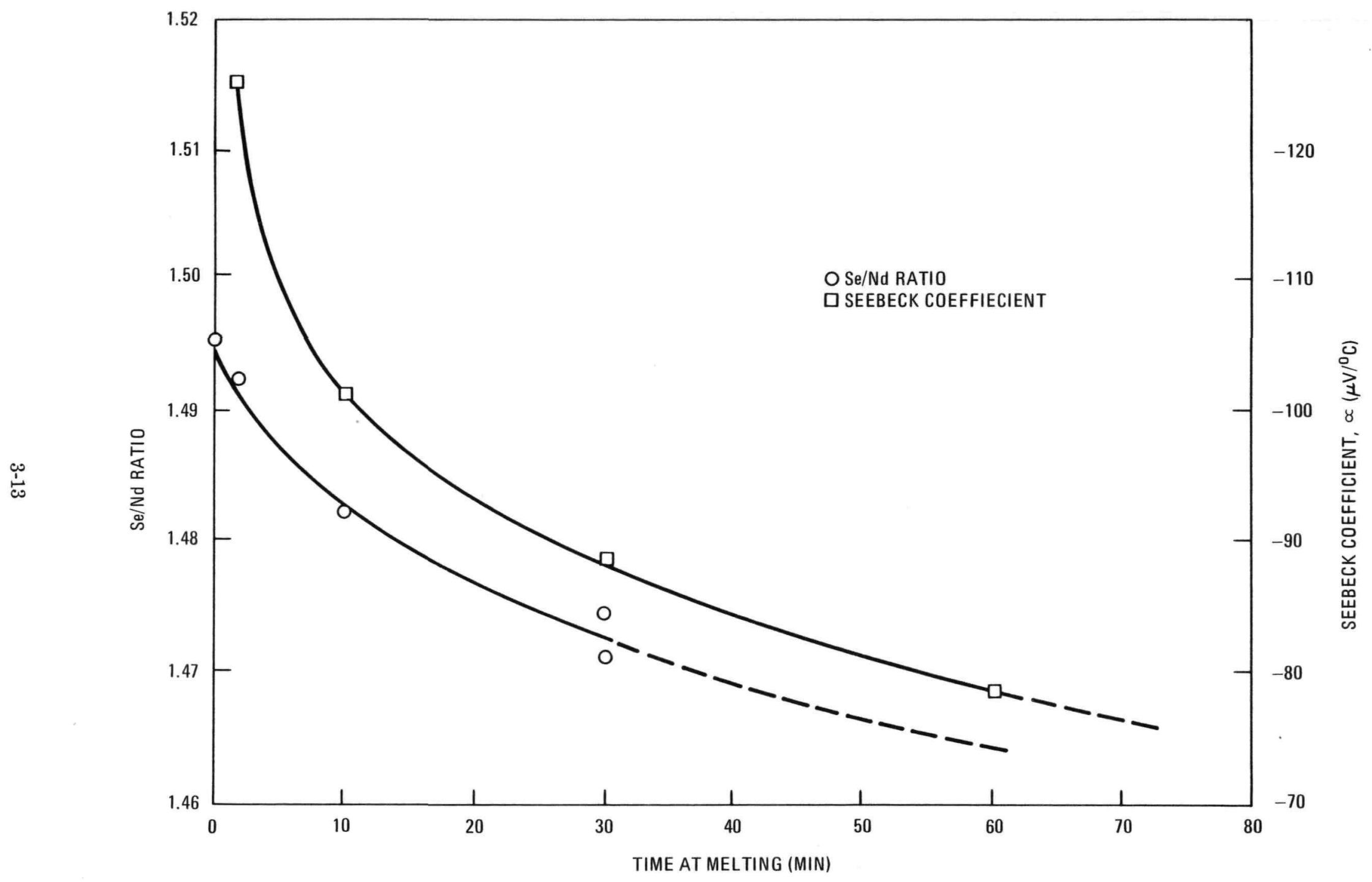

Fig. 3-5. Control of $N d S e_{1,5}$, composition and Seebeck coefficient 


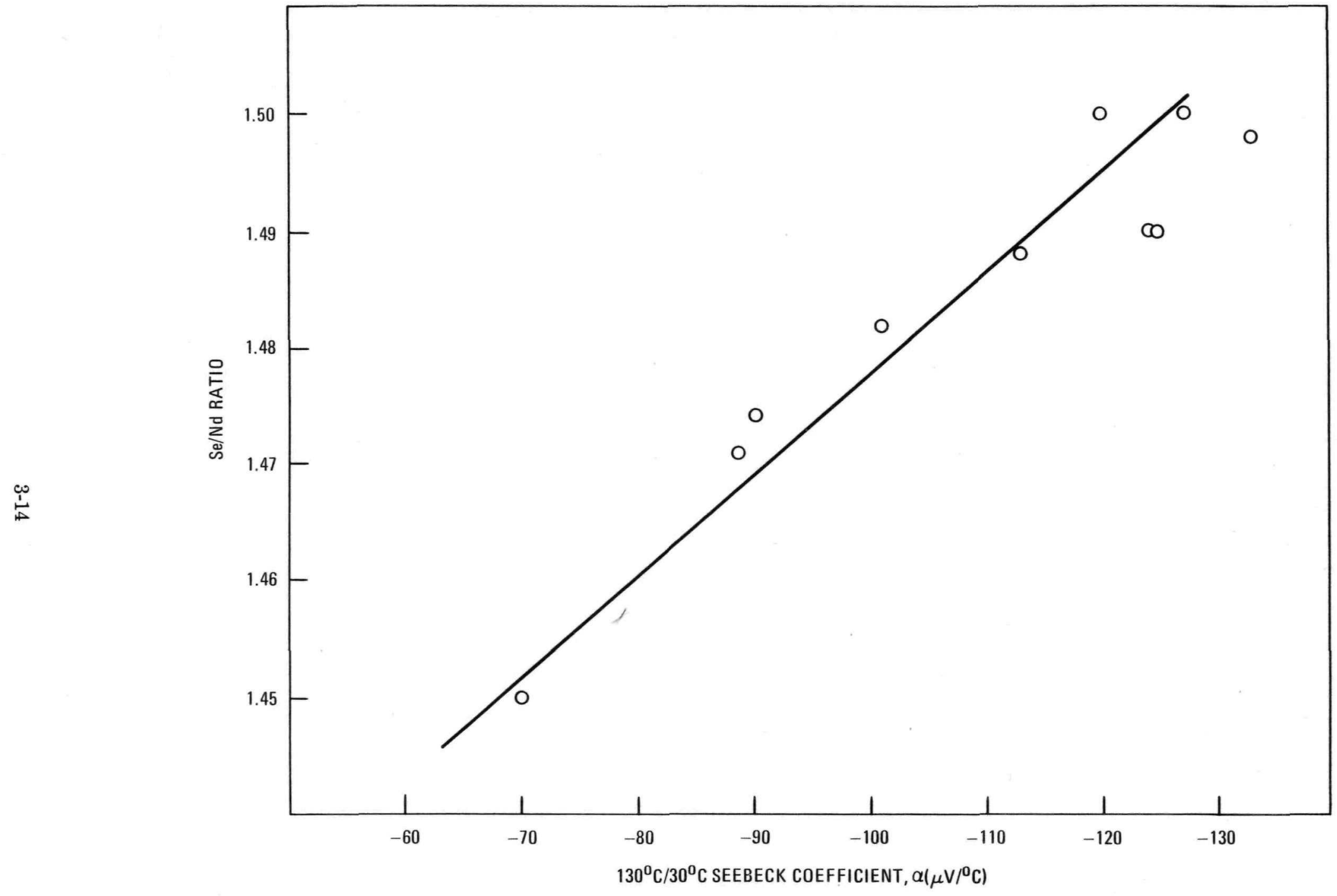

Fig. 3-6. Seebeck coefficient versus Se/Nd ratios for melted NdSe $e_{1.5}$ x samples 
The significance of these experiments is that the Se/Nd ratio, Seebeck coefficient, and resistivity of $\mathrm{NdSe}_{1.5-\mathrm{x}}$ can be controlled by the total time held at the melting temperature. A relationship should also exist between thermal conductivity and $\mathrm{Se} / \mathrm{Nd}$ ratio, but this was not determined. Optimizing these thermoelectric properties plus factoring in practical considerations of element strength, a $\mathrm{Se} / \mathrm{Nd}$ ratio can be selected which will maximize the efficiency of the $\mathrm{NdSe}_{1.5-x}$ used for $\mathrm{N}$-element fabrication.

\section{2. $\quad \mathbf{N d S e}_{1.5-x}$ Element Fabrication Studies}

Trial hot pressing of $\mathrm{NdSe}_{1.5-\mathrm{x}}$ elements was evaluated. This effort was intended to optimize the mechanical strength and thermoelectric properties of the $\mathrm{N}$ element.

\subsubsection{Hot pressing $\mathrm{NdSe}_{1.5-x}$ Made by Method 1 GA or Ames Laboratory Processes from Controlled Ratios of Neodymium and Selenium Starting Materials}

3.2.1.1. $\quad \boldsymbol{N d S e}_{1.5-\mathrm{x}}$ and $\mathbf{N d S e _ { 1 . 5 - x }}$ Plus Additives. Several experiments have been conducted on vacuum hot pressing of Method $1 \mathrm{NdSe}_{1.49}$ powder produced by Ames Laboratory. For all hot pressing temperatures, a dense compact was produced. The compacts were very friable as produced, even when nickel powder $(-270$ mesh) was used as a hot pressing additive. Compacts with $1 \%$ nickel added showed much higher room temperature Seebeck coefficients after hot pressing than did those without nickel, and densification could be accomplished at lower temperatures when nickel was added. At a hot pressing temperature of $1400^{\circ} \mathrm{C}$, increasing the nickel content from $1 \%$ to $2 \%$ resulted in a much lower Seebeck value. Table 3-8 gives the results of these hot pressing experiments. Sound compacts were fabricated for both the $\mathrm{NdSe}_{1.49}$ and $\mathrm{NdSe}_{1.50}$ Method 1 compositions produced by Ames Laboratory. Both alloys contained $1 \mathrm{wt} \%$ nickel powder as a pressing aid. Hot pressing was performed and at $1400^{\circ} \mathrm{C}$ and $34.5 \mathrm{MPa}(5000 \mathrm{psi})$ for $15 \mathrm{~min}$ in 0.5 $\mathrm{cm}(0.200$-in.) diameter graphite dies. The die was slow cooled from the hot pressing temperature to minimize thermal stressing of the compact. The compacts were crack free and ejected from the die without difficulty. Density for compacts of both alloys was 6.1 $\mathrm{g} / \mathrm{cm}^{3}$. The Seebeck coefficients of the $\mathrm{NdSe}_{1.9}$ plus $1 \%$ nickel and $\mathrm{NdSe}_{1.50}$ plus $1 \%$ nickel alloys were -303 and $-311 \mu \mathrm{V} /{ }^{\circ} \mathrm{C}$, respectively, which are somewhat higher than previously obtained.

One compact of the $\mathrm{NdSe}_{1.50}$ plus $1 \%$ nickel alloy was tested in the thermal gradient station at zero current to determine the Seebeck coefficient at elevated temperatures. Table 3-9 shows the results.

Scanning electron microscopy (SEM) examinations of hot pressed alloys were performed both with and without nickel additions. Figures 3-7 and 3-8 show typical microstructures observed on fracture surfaces. Very little surface-connected porosity was observed on the material hot pressed without nickel, while numerous cleavage facets were seen. The material hot pressed with nickel additions showed very few cleavage facets, considerable surface-connected porosity, and uniformly dispersed nickel particles.

Additional experiments were performed to develop a satisfactory vacuum hot pressing schedule for $\mathrm{NdSe}_{1.5-\mathrm{x}}$. These experiments used selenide compositions supplied by the Ames Laboratory Method 1 process. Table 3-10 shows the results of Seebeck coefficient determinations at room temperature after hot pressing. Alloys with nickel additions 
TABLE 3-8

THERMAL EMF OF HOT PRESSED NdSe $\mathrm{e}_{1.49}$

\begin{tabular}{c|c|c}
\hline $\begin{array}{c}\text { Hot-Pressing Temperature } \\
\left({ }^{\circ} \mathbf{C}\right)^{(\mathrm{a})}\end{array}$ & Additive & $\begin{array}{c}\text { Room Temperature Seebeck } \\
\text { Coefficient, } \alpha, \text { After Hot Pressing } \\
\left(\mu \mathbf{V} /{ }^{\circ} \mathbf{C}\right)\end{array}$ \\
\hline 1575 & - & -142.0 \\
1675 & - & -118.6 \\
1300 & $1 \% \mathrm{Ni}$ & -260.8 \\
1400 & $1 \% \mathrm{Ni}$ & -210.0 \\
1400 & $2 \% \mathrm{Ni}$ & -60.0 \\
\hline
\end{tabular}

(a) $34.5 \mathrm{MPa}$ (5000 psi) pressure, $10 \mathrm{~min}$ under load.

TABLE 3-9

NdSe $_{1.50}+1 \%$ NICKEL SEEBECK COEFFICIENT

\begin{tabular}{c|c|c|c}
\hline \multicolumn{3}{c|}{ Temperature $\left({ }^{\circ} \mathbf{C}\right)$} & \multirow{2}{*}{$\begin{array}{c}\text { Seebeck Coefficient, } \alpha \\
\left(\mu \mathbf{V} /{ }^{\circ} \mathbf{C}\right)\end{array}$} \\
\hline $\mathbf{T}_{\mathrm{H}}$ & $\mathbf{T}_{\mathrm{C}}$ & $\overline{\mathbf{T}}$ & -365.00 \\
100 & 16 & 58 & -334.43 \\
200 & 17 & 108 & -333.33 \\
300 & 18 & 159 & -339.47 \\
400 & 20 & 210 & -335.43 \\
500 & 23 & 262 & -331.09 \\
600 & 29 & 315 & -337.11 \\
700 & 35 & 368 & -339.82 \\
748 & 41 & 395 & -355.08 \\
749 & 90 & 420 & -365.40 \\
749 & 119 & 434 & \\
\hline
\end{tabular}



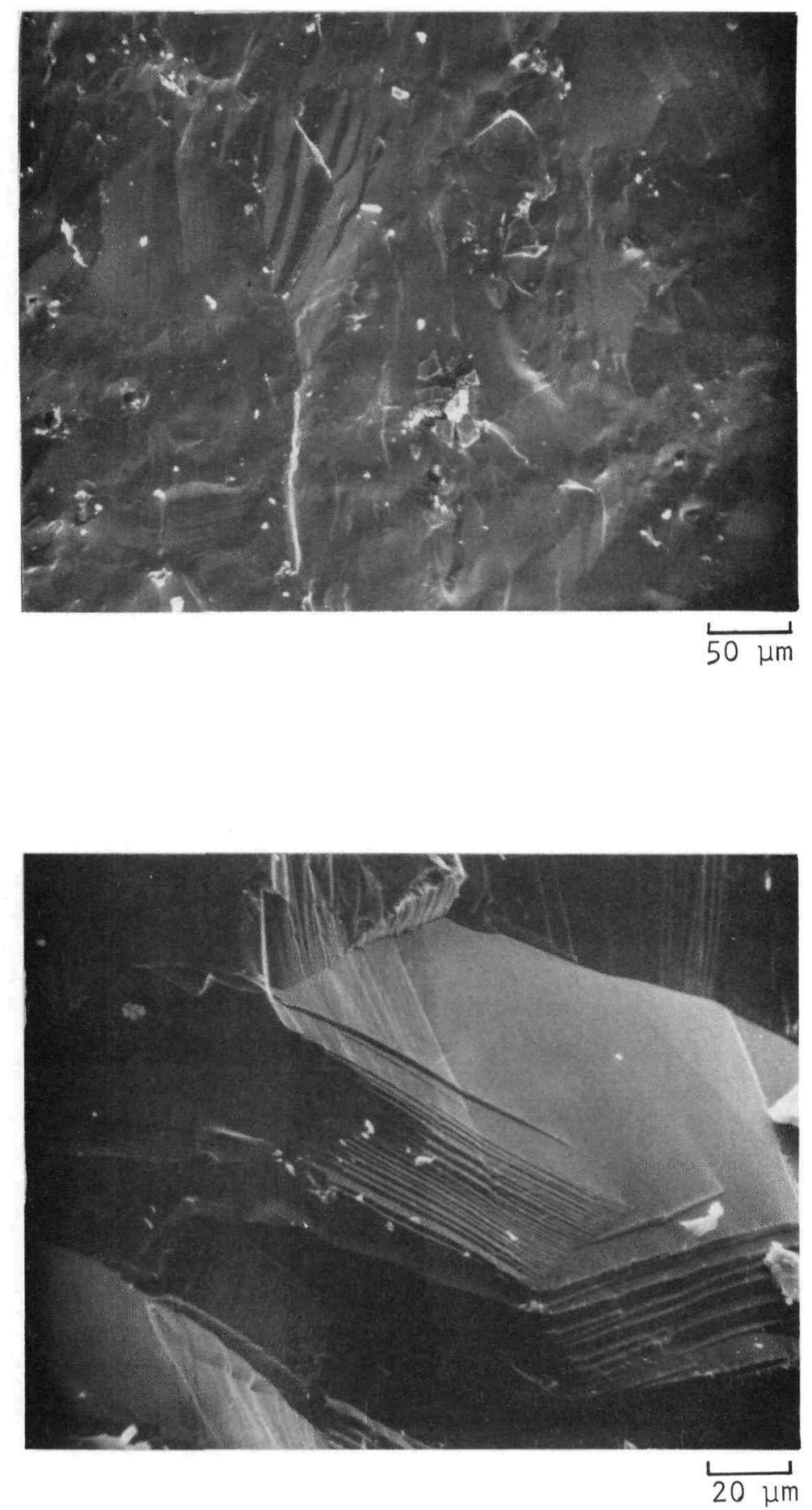

Fig. 3-7. Fracture surface of hot-pressed $N d S e_{1.5}$ with no nickel powder additions 

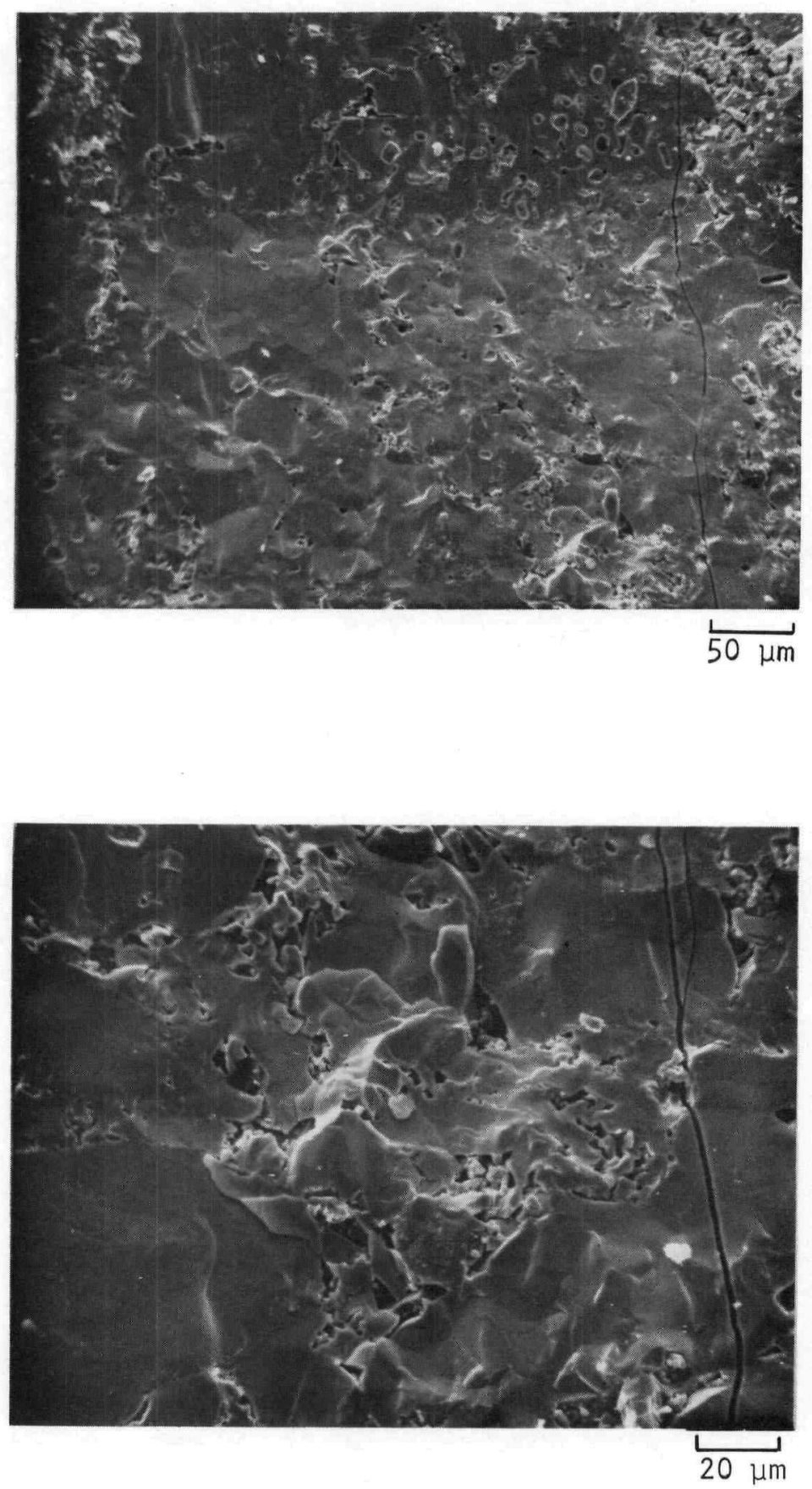

Fig. 3-8. Fracture surface of hot-pressed $\mathrm{NdSe}_{1.5}$ plus $1 \%$ nickel 
TABLE 3-10

SEEBECK COEFFICIENT OF NdSe $\mathbf{e}_{1.5}$ AND NdSe $_{1.5}+1 \%$ NICKEL ALLOYS

\begin{tabular}{l|c|c|c}
\hline \multicolumn{1}{c|}{ Alloy } & $\begin{array}{c}\text { Hot-Pressed } \\
\text { Temperature } \\
\left({ }^{\circ} \mathbf{C}\right)\end{array}$ & $\begin{array}{c}\text { Hot-Pressed } \\
\text { Pressure } \\
{[\mathbf{M P a}(\mathbf{p s i})]}\end{array}$ & $\begin{array}{c}\text { Seebeck } \\
\text { Coefficient, } \alpha \\
\left(\mu \mathbf{V} /{ }^{\circ} \mathbf{C}\right)\end{array}$ \\
\hline $\mathrm{NdSe}_{1.495}+1 \% \mathrm{Ni}$ & 1400 & $98(14,250)$ & -193.3 \\
$\mathrm{NdSe}_{1.495}$ & 1100 & $98(14,250)$ & -1.1 \\
$\mathrm{NdSe}_{1.498}+1 \% \mathrm{Ni}$ & 1400 & $98(14,250)$ & -237.4 \\
$\mathrm{NdSe}_{1.498}+1100$ & $112(16,280)$ & -3.3 \\
$\mathrm{NdSe}_{1.504}+1 \% \mathrm{Ni}$ & 1400 & $112(16,280)$ & -188.0 \\
$\mathrm{NdSe}_{1.504}+1 \% \mathrm{Ni}$ & 1150 & $112(16,280)$ & -4.3 \\
$\mathrm{NdSe}_{1.49}+1 \% 9.0$ \\
$\mathrm{NdSe}_{1.495}$ & 1300 & $55(8,000)$ & -259.0 \\
$\mathrm{NdSe}_{1.495}+1 \% \mathrm{Ni}$ & 1300 & $96.5(14,000)$ & -240.1 \\
$\mathrm{NdSe}_{1.495}$ & 1300 & $82.7(12,000)$ & -267.4 \\
$\mathrm{NdSe}_{1.495}+1 \% \mathrm{Ni}$ & 1300 & $96.5(14,000)$ & -65.0 \\
$\mathrm{NdSe}_{1.495}+1.5 \% \mathrm{Ni}$ & 1200 & $96.5(14,000)$ & -61.0 \\
$\mathrm{NdSe}_{1.5}+1 \% \mathrm{Ni}$ & 1100 & $96.5(14,000)$ & -86.0 \\
\hline
\end{tabular}


consistently show greatly reduced Seebeck coefficients in the as-hot-pressed condition. Several compacts were aged for 17 and $64 \mathrm{~h}$ at $1000^{\circ} \mathrm{C}$, and the Seebeck coefficient was remeasured. Table 3-11 shows these results. The alloy prepared without nickel additions showed a slight increase in Seebeck coefficient, while some alloys containing nickel additions showed P-type behavior after aging for $17 \mathrm{~h}$ and the expected $\mathrm{N}$-type behavior after $64 \mathrm{~h}$.

Elements hot pressed from $\mathrm{NdSe}_{1.5}$ powder without nickel additions show much improved Seebeck coefficients but are extremely friable and could not be handled for further processing. The original intent of nickel additions to the $\mathrm{NdSe}_{1.5}$ alloys was to improve as-fabricated strength of the selenide elements. Figure 3-9 shows a compilation of recent data on the as-fabricated Seebeck coefficient of three $\mathrm{NdSe}_{1.5}$ alloys with $1 \%$ nickel added as a hot pressing aid. The Seebeck coefficient clearly increases with hot pressing temperatures, although the alloys pressed at lower temperatures are felt to attain the same level of thermal electromotive force (emf) after aging.

Table 3-12 summarizes the results of hot pressing. In $\mathrm{NdSe}_{1.5-\mathrm{x}}$, which was prepared by controlled composition starting materials, the addition of nickel helped to reduce the friability of the hot pressed elements but degraded the thermoelectric properties. A variety of other dispersed phases was examined as hot-pressing aids because of the transient chemical instability of nickel additions in the $\mathrm{NdSe}_{1.5}$ alloys. These include iron, chromium, rhenium, molybdenum, tungsten, graphite, and $\mathrm{Cr}_{23} \mathrm{C}_{6}$. Table $3-13$ shows the results of hot pressing trials using these additives. Chromium, tungsten, and graphite appear to warrant further investigation. Chromium was especially attractive because high Seebeck coefficients were obtained after hot pressing at fairly low temperatures. (Note in Fig. 3-9, described previously, that nickel additions result in much lower Seebeck coefficients than observed for chromium when hot pressing is performed at $1200^{\circ} \mathrm{C}$ ). The ends of the $\mathrm{NdSe}_{1.495}$ plus $1 \%$ chromium compact were ion plated with rhenium for resistivity and Seebeck coefficient measurements at $\mathrm{T}_{\mathrm{H}}$ up to $750^{\circ} \mathrm{C}$. These results (Table 3-14) show that Seebeck coefficients and resistances increased continuously with temperature. The 392.3 milliohm resistance at $\mathrm{T}-66^{\circ} \mathrm{C}$ corresponds to a resistivity 30 milliohm-cm, while the 548.0 milliohm resistance at $428^{\circ} \mathrm{C}$ corresponds to a resistivity of 42.03 milliohm-cm.

The Method $1 \mathrm{NdSe}_{1.495}$ alloy elements with several different hot pressing additives were aged at $965^{\circ} \mathrm{C}$ for $94 \mathrm{~h}$. The Seebeck coefficient, after aging, was measured for comparison with the as-hot-pressed value. This test was performed to assess the relative stability of the dispersed metal phases in the $\mathrm{NdSe}_{1.5-\mathrm{x}}$ matrix. Table 3-15 shows the results. Those compacts showing positive Seebeck coefficients as-hot pressed showed relatively little change in Seebeck coefficient. Compacts showing negative Seebeck coefficients as-hot pressed become more negative after aging. None of the additives shown appear adequate for hot pressing with $\mathrm{NdSe}_{1.5-\mathrm{x}}$.

Additional elements have been prepared from the $\mathrm{NdSe}_{1.495}$ composition using $1 \%$ chromium or the combination of $0.5 \%$ tungsten and $0.5 \%$ chromium as hot-pressing aids. Table 3-16 shows as-fabricated properties of these elements. Metallographic examination of the alloys containing chromium additions showed cracking in the vicinity of large chromium particles. Areas of the element containing fine chromium powder particles were generally crack free. 
TABLE 3-11

NdSe $_{1.5-\mathrm{x}}$ PROPERTIES AFTER AGING AT $1000^{\circ} \mathrm{C}$

\begin{tabular}{l|c|c}
\hline \multicolumn{1}{c|}{ Alloy } & $\begin{array}{c}\text { Aging Time } \\
(\mathbf{h})\end{array}$ & $\begin{array}{c}\text { Seebeck Coefficient, } \boldsymbol{\alpha} \\
\left(\mu \mathbf{V} /{ }^{\circ} \mathbf{C}\right)\end{array}$ \\
\hline $\mathrm{NdSe}_{1.495}$ & 0 & -267.4 \\
$\mathrm{NdSe}_{1.495}$ & 17 & -293.0 \\
$\mathrm{NdSe}_{1.495}$ & 64 & -294.0 \\
$\mathrm{NdSe}_{1.495}+1 \% \mathrm{Ni}$ & 0 & -65.0 \\
$\mathrm{NdSe}_{1.495}+1 \% \mathrm{Ni}$ & 17 & +6.3 \\
$\mathrm{NdSe}_{1.495}+1 \% \mathrm{Ni}$ & 64 & -100.0 \\
$\mathrm{NdSe}_{1.495}+1.5 \%$ & 0 & -86.0 \\
$\mathrm{Ni}$ & & \\
$\mathrm{NdSe}_{1.495}+1.5 \%$ & 17 & +5.3 \\
$\mathrm{Ni}_{\mathrm{NdSe}}$ & & -142.0 \\
$\mathrm{Ni}_{1.495}+1.5 \%$ & 64 & -175.0 \\
$\mathrm{NdSe}_{1.5}+1 \% \mathrm{Ni}$ & & +6.8 \\
$\mathrm{NdSe}_{1.5}+1 \% \mathrm{Ni}$ & 17 & -157.0 \\
$\mathrm{NdSe}_{1.5}+1 \% \mathrm{Ni}$ & 64 & \\
\hline
\end{tabular}

TABLE 3-12

TYPICAL HOT-PRESSED NdSe $\mathrm{x}_{\mathrm{x}}$ PROPERTIES

\begin{tabular}{l|l|c|l}
\hline \multicolumn{1}{c|}{$\mathbf{x}$} & $\begin{array}{c}\text { Hot-Pressed } \\
\text { Schedule } \\
\left({ }^{\circ} \mathbf{C} / \mathbf{p s i} / \mathbf{m i n}\right)\end{array}$ & $\begin{array}{c}\text { Seebeck } \\
\text { Coefficient, } \alpha \\
\left(\mu \mathbf{V} /{ }^{\circ} \mathbf{C}\right)\end{array}$ & \multicolumn{1}{c}{ Comments } \\
\hline $1.46(\mathrm{GA})$ & $1575 / 5000 / 10$ & -40.1 & Two-phase produce \\
$1.49(\mathrm{Ames})$ & $1575 / 5000 / 10$ & -142.0 & Single phase \\
1.49 & $1675 / 5000 / 10$ & -118.6 & Single phase \\
$1.49+1 \% \mathrm{Ni}$ & $1300 / 5000 / 10$ & -260.8 & Single phase \\
$1.49+1 \% \mathrm{Ni}$ & $1400 / 5000 / 10$ & -210.0 & Single phase \\
$1.49+1 \% \mathrm{Ni}$ & $1400 / 5000 / 15^{(a)}$ & -303.0 & Sound element \\
$1.5(\mathrm{Ames})$ & $1575 / 5000 / 10$ & -136.1 & Inhomogeneous single phase \\
$1.5+1 \% \mathrm{Ni}$ & $1400 / 5000 / 15^{(\mathbf{a})}$ & -311.0 & Sound element \\
\hline
\end{tabular}

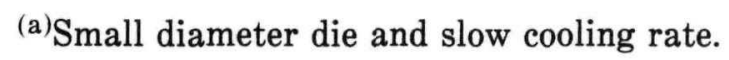




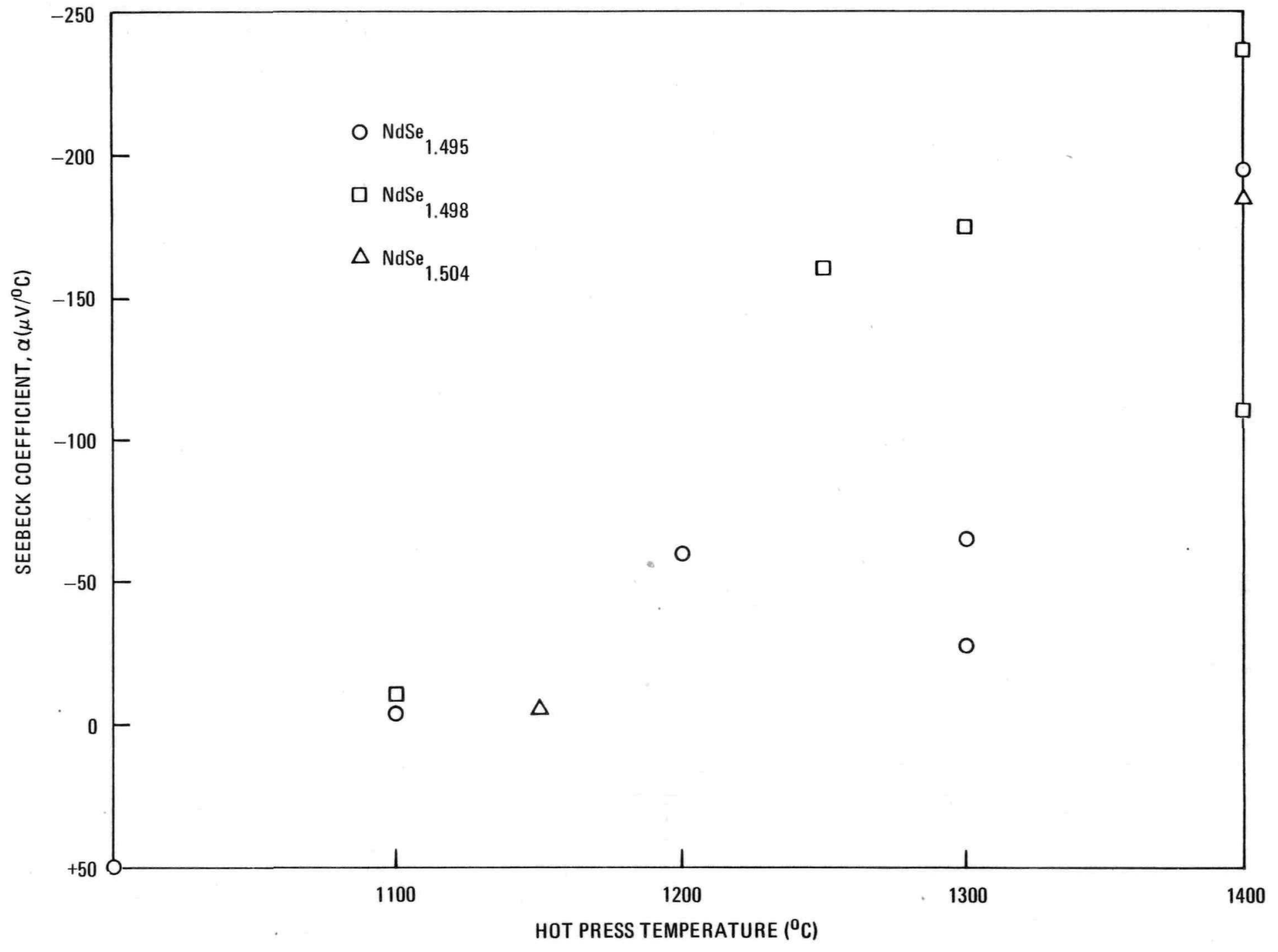

Fig. 3-9. Seebeck coefficient of $\mathrm{NdSe}_{1.5}$ plus $1 \%$ nickel alloys 
TABLE 3-13

HOT PRESSING ADDITIVES FOR NdSe $\mathbf{e}_{1.495}$

\begin{tabular}{l|c|c|l}
\hline \multicolumn{1}{c|}{$\begin{array}{c}\text { Additive } \\
(\mathbf{1 \% )})\end{array}$} & $\begin{array}{c}\text { Pressing } \\
\text { Temperature } \\
\left({ }^{\circ} \mathbf{C}\right)\end{array}$ & $\begin{array}{c}\text { Seebeck } \\
\text { Coefficient, } \alpha \\
\left(\mu \mathbf{V} /{ }^{\circ} \mathbf{C}\right)\end{array}$ & \multicolumn{1}{c}{ Comments } \\
\hline Iron & 1150 & +11.6 & Numerous cracks in element \\
Chromium & 1200 & -187.0 & Sound element \\
Rhenium & 1400 & +8.5 & Sound element \\
Molybdenum & 1400 & +8.8 & Sound element \\
Tungsten & 1400 & -308.4 & Slight cracking \\
Graphite & 1475 & -260.0 & Sound element, low density \\
Chromium carbide & 1500 & -250.6 & Slight cracking \\
\hline
\end{tabular}

TABLE 3-14

IN-GRADIENT TESTING OF $\mathbf{N d}_{2} \mathrm{Se}_{3}+1 \% \mathbf{C r}$

\begin{tabular}{r|c|c|c|c|c}
\hline \multicolumn{2}{c|}{ Temperature $\left({ }^{\circ} \mathbf{C}\right)$} & $\begin{array}{c}\text { Output } \\
\text { Voltage, } \mathbf{V}_{\mathrm{o}} \\
(\mathbf{m V})\end{array}$ & $\begin{array}{c}\text { Seebeck } \\
\text { Coefficient, } \alpha \\
\left(\mu \mathbf{V} /{ }^{\circ} \mathbf{C}\right)\end{array}$ & $\begin{array}{c}\text { Resistance } \\
(\mathbf{m} \Omega)\end{array}$ \\
\hline $\mathbf{T}_{\mathrm{H}}$ & $\mathbf{T}_{\mathrm{C}}$ & $\overline{\mathbf{T}}$ & - & - & 378.4 \\
19 & 31 & - & 12.10 & 177.94 & 392.3 \\
100 & 32 & 66 & 17.40 & 174.00 & 392.7 \\
133 & 33 & 83 & 20.80 & 180.87 & 409.0 \\
150 & 35 & 93 & 31.00 & 189.02 & 414.0 \\
200 & 36 & 118 & 35.60 & 221.11 & 410.4 \\
200 & 39 & 120 & 48.20 & 233.98 & 420.6 \\
250 & 44 & 147 & 61.70 & 242.91 & 428.5 \\
300 & 46 & 173 & 75.00 & 250.00 & 434.4 \\
350 & 50 & 200 & 89.30 & 259.59 & 448.5 \\
400 & 56 & 228 & 103.10 & 264.36 & 459.7 \\
450 & 60 & 255 & 119.00 & 273.56 & 479.0 \\
500 & 65 & 283 & 134.40 & 280.00 & 510.9 \\
550 & 70 & 310 & 150.50 & 288.31 & 548.5 \\
600 & 78 & 339 & 167.30 & 295.58 & 574.2 \\
650 & 84 & 367 & 183.40 & 302.14 & 555.6 \\
700 & 93 & 397 & 200.00 & 310.08 & 548.0 \\
750 & 105 & 428 & & & \\
\hline
\end{tabular}


TABLE 3-15

AGING EFFECTS ON NdSe ${ }_{1.495}$ MATRIX ALLOYS

\begin{tabular}{l|c|c}
\hline \multirow{2}{*}{\multicolumn{1}{c|}{ Additive }} & \multicolumn{2}{|c}{ Seebeck Coefficient, $\alpha\left(\mu \mathrm{V} /{ }^{\circ} \mathbf{C}\right)$} \\
\cline { 2 - 3 } & As-Pressed & Post-Age $^{(\text {a) }}$ \\
\hline Iron & +11.6 & +6.4 \\
Rhenium & +8.5 & +7.3 \\
Molybdenum & 8.8 & +7.4 \\
Tungsten & -308.4 & -445.3 \\
Graphite & -260.0 & -90.0 \\
Chromium carbide & -250.6 & -535.4 \\
\hline
\end{tabular}

(a) $94 \mathrm{~h} / 965^{\circ} \mathrm{C}$.

TABLE 3-16

PROPERTIES OF NdSe 1.495 $_{1}$ ALLOYS

\begin{tabular}{l|c|c|c|c}
\hline \multicolumn{1}{c|}{ Additive } & $\begin{array}{c}\text { Hot Pressing } \\
\text { Temperature } \\
\left({ }^{\circ} \mathbf{C}\right)\end{array}$ & $\begin{array}{c}\overline{\mathbf{T}}=\mathbf{8 0}^{\circ} \mathbf{C} \\
\text { Seebeck } \\
\text { Coefficient, } \alpha \\
\left(\mu \mathbf{V} /{ }^{\circ} \mathbf{C}\right)\end{array}$ & $\begin{array}{c}\text { Room } \\
\text { Temperature } \\
\text { Resistivity, } \rho \\
(\Omega \text {-cm })\end{array}$ & $\begin{array}{c}\text { Density } \\
\left(\mathbf{g} / \mathbf{c m}^{3}\right)\end{array}$ \\
\hline $1 \% \mathrm{Cr}$ & 1275 & -192.0 & $\mathrm{ND}^{(\mathrm{a})}$ & 6.52 \\
$1 \% \mathrm{Cr}$ & 1275 & -220.0 & $0.054^{(\mathrm{b})}$ & 6.53 \\
$0.5 \% \mathrm{~W}+0.5 \% \mathrm{Cr}$ & 1500 & -174.0 & $\mathrm{ND}$ & 6.60 \\
\hline
\end{tabular}

(a) Not determined.

(b) After ion plating rhenium end caps. 
The compact containing $0.5 \%$ tungsten and $0.5 \%$ chromium additions was mounted in the test station for elevated temperature Seebeck coefficient measurements. Table 3-17 shows the results of this test. After $39 \mathrm{~h}$ exposure at $\mathrm{T}_{\mathrm{H}}=734^{\circ} \mathrm{C}, \mathrm{T}_{\mathrm{C}}=78^{\circ} \mathrm{C}$, and $\mathrm{T}$ $=406^{\circ} \mathrm{C}$, the $\mathrm{mV}$ output was 185.0 and the Seebeck coefficient was $282.20 \mu \mathrm{V} /{ }^{\circ} \mathrm{C}$, which is somewhat lower than the value obtained during heatup. The test was terminated after $69 \mathrm{~h}$ total exposure.

3.2.1.2. (Nd,Gd)S $\boldsymbol{e}_{1.5-x}$ Alloys. Gadolinium was added to accelerate the reaction kinetics. The neodynium was present to stabilize cubic rare earth selenide. A series of $(\mathrm{Nd}, \mathrm{Gd}) \mathrm{Se}_{1.5}$ alloys was prepared by reacting elemental ingredients to $1010^{\circ} \mathrm{C}$ in evacuated quartz vials. The alloys were held at temperature for $100 \mathrm{~h}$. The compositions prepared correspond to $\mathrm{Nd}_{0.898}, \mathrm{Gd}_{0.102} \mathrm{Se}_{1.493}, \mathrm{Nd}_{0.76} \mathrm{Gd}_{0.24} \mathrm{Se}_{1.479}, \mathrm{Nd}_{0.495} \mathrm{Gd}_{0.505} \mathrm{Se}_{1.479}$, and $\mathrm{Nd}_{0.253} \mathrm{Gd}_{0.747} \mathrm{Se}_{1.478}$. After reaction, X-ray diffraction examination of the products indicated that each was two phase, consisting of one cubic phase (presumably $\mathrm{NdSe}_{1.5}$ ) and one orthorhomic phase (presumably $\mathrm{GdSe}_{1.5}$ ). The reaction product was ground and hot pressed at temperatures sufficient to produce cubic materials and reexamined by X-ray diffraction.

In no case was a structurally sound $0.95-\mathrm{cm}(0.375$-in.) diameter compact obtained. This is probably to be expected in light of the recent results on $\mathrm{NdSe}_{1.5}$ plus $1 \%$ nickel which indicate that small compact diameters and slow cooling rates are required. Each composition still consisted of two cubic phases with very similar lattice parameters. The amount of second (cubic) phase increased with increasing $\mathrm{Gd} / \mathrm{Nd}$ ratio to approximateì $50 \%$ at the $\mathrm{Nd}_{0.25} \mathrm{Gd}_{0.75} \mathrm{Se}_{1.50}$ composition. Table 3-18 summarizes observations on the $(\mathrm{Nd}, \mathrm{Gd}) \mathrm{Se}_{1.5}$ alloys.

\subsubsection{Hot Pressing NdSe $e_{1.5-x}$ Made by Method 2 from the Diselenide Process}

An evaluation was made of elements prepared by hot pressing $\mathrm{Nd}_{2} \mathrm{Se}_{3}$ from the deselenide $\mathrm{NdSe}_{2}$ process from $\mathrm{NdSe}_{1.5-\mathrm{x}}$ prepared and melted by both GA and Ames Laboratory. Table 3-19 shows the reproducibility of the results of near-ambienttemperature measurements of density, Seebeck coefficient, and resistivity of some Ames Laboratory-supplied NdSe ${ }_{1.489}$. Density and Seebeck coefficient were quite repeatable. Resistivity measurements were made with a four-point probe, but without coated contacts on the ends of the elements. Data scatter in this measurement was partly because the ends were not metallized.

The Seebeck coefficients and resistivities were compared for $\mathrm{NdSe}_{1 . \overline{-}-\mathrm{x}}$ by the following methods:

1. Prepared and melted at GA.

2. Prepared at Ames Laboratory and melted at GA.

3. Prepared and melted at Ames Laboratory. 
TABLE 3-17

SEEBECK COEFFICIENT OF NdSe e $_{1.45}$

$+0.5 \% \mathrm{~W}+\mathbf{0 . 5 \%} \mathrm{Cr}$ (7958-48-3)

\begin{tabular}{|c|c|c|c|c|c|c|}
\hline \multicolumn{4}{|c|}{ Temperature $\left({ }^{\circ} \mathrm{C}\right)$} & \multirow{2}{*}{$\begin{array}{c}\text { Output } \\
\text { Voltage, } V_{\mathrm{o}} \\
\text { (mV) }\end{array}$} & \multirow{2}{*}{$\begin{array}{c}\text { Seebeck } \\
\text { Coefficient, } \alpha \\
\left(\mu \mathrm{V} /{ }^{\circ} \mathrm{C}\right)\end{array}$} & \multirow[b]{2}{*}{ Comments } \\
\hline $\mathbf{T}_{\mathrm{H}}$ & $\mathbf{T}_{\mathrm{C}}$ & $\Delta \mathbf{T}$ & $\overline{\mathbf{T}}$ & & & \\
\hline 23 & 20 & - & - & 0.5 & - & \\
\hline 50 & 21 & 29 & 36 & 7.7 & 265.52 & \\
\hline 150 & 24 & 126 & 87 & 26.0 & 206.35 & \\
\hline 175 & 25 & 150 & 100 & 31.3 & 208.67 & \\
\hline 200 & 25 & 175 & 113 & 40.8 & 233.14 & \\
\hline 250 & 26 & 224 & 138 & 53.7 & 239.73 & \\
\hline 300 & 27 & 273 & 164 & 67.4 & 246.89 & \\
\hline 350 & 29 & 321 & 190 & 81.5 & 253.89 & \\
\hline 400 & 31 & 369 & 216 & 95.5 & 258.81 & \\
\hline 450 & 32 & 418 & 241 & 110.8 & 265.07 & \\
\hline 500 & 34 & 466 & 267 & 125.8 & 269.96 & \\
\hline 550 & 36 & 514 & 293 & 142.0 & 276.26 & \\
\hline 600 & 38 & 562 & 319 & 158.8 & 282.56 & \\
\hline 650 & 41 & 609 & 346 & 176.4 & 289.66 & \\
\hline 700 & 43 & 657 & 372 & 193.3 & 294.22 & \\
\hline 750 & 46 & 704 & 398 & 211.9 & 300.99 & \\
\hline 752 & 46 & 706 & 399 & 217.4 & 307.93 & \\
\hline 752 & 46 & 706 & 399 & 218.8 & 309.92 & \\
\hline 751 & 46 & 705 & 399 & 218.2 & 309.50 & \\
\hline 751 & 45 & 706 & 398 & 214.7 & 304.11 & Hold $14 \mathrm{~h}$ \\
\hline 748 & 45 & 703 & 397 & 204.3 & 290.62 & \\
\hline 751 & 70 & 681 & 411 & 200.7 & 294.71 & \\
\hline 751 & 80 & 671 & 416 & 199.0 & 296.57 & \\
\hline 752 & 90 & 662 & 421 & 197.2 & 297.89 & \\
\hline 751 & 100 & 651 & 426 & 195.3 & 300.00 & \\
\hline 751 & 110 & 641 & 431 & 193.5 & 301.87 & \\
\hline 751 & 120 & 631 & 436 & 191.8 & 303.96 & \\
\hline 749 & 129 & 620 & 439 & 189.9 & 306.29 & \\
\hline 748 & 138 & 610 & 443 & 187.8 & 307.87 & \\
\hline 747 & 141 & 606 & 444 & 187.2 & 308.91 & $\begin{array}{l}\text { Decrease cold side temp at } \\
30 \mathrm{~h}\end{array}$ \\
\hline 734 & 78 & 656 & 406 & 185.0 & 282.20 & $69 \mathrm{~h}$ \\
\hline
\end{tabular}


TABLE 3-18

RESULTS ON HOT-PRESSED (Nd,Gd)Se $e_{1.5}$ ALLOYS

\begin{tabular}{|c|c|c|c|}
\hline Composition & $\begin{array}{c}\text { Hot-Pressed } \\
\text { Schedule } \\
\left({ }^{\circ} \mathrm{C} / \text { psi } / \mathrm{min}\right)\end{array}$ & $\begin{array}{c}\text { Seebeck } \\
\text { Coefficient, } \alpha \\
\left(\mu \mathrm{V} /{ }^{\circ} \mathrm{C}\right)\end{array}$ & Comments \\
\hline $\mathrm{Nd}_{0.899} \mathrm{Gd}_{0.102} \mathrm{Se}_{1.493}$ & $1500 / 5000 / 10$ & -139.7 & $\begin{array}{l}\text { Very small amount of second } \\
\text { (cubic) phase }\end{array}$ \\
\hline $\begin{array}{l}\mathrm{Nd}_{0.898} \mathrm{Gd}_{0.102} \mathrm{Se}_{1.493} \\
+1 \% \mathrm{Ni}\end{array}$ & $1400 / 5000 / 10$ & -223.6 & $\begin{array}{l}\text { Very small amount of second } \\
\text { (cubic) phase }\end{array}$ \\
\hline $\begin{array}{l}\mathrm{Nd}_{0.898} \mathrm{Gd}_{0.102} \mathrm{Se}_{1.493} \\
+1 \% \mathrm{Ni}\end{array}$ & $1200 / 7000 / 10$ & -177.0 & $\begin{array}{l}\text { Very small amount of second } \\
\text { (cubic) phase }\end{array}$ \\
\hline $\mathrm{Nd}_{0.760} \mathrm{Gd}_{0.240} \mathrm{Se}_{1.479}$ & $1500 / 5000 / 10$ & -269.0 & $\begin{array}{l}\text { Very small amount of second } \\
\text { (cubic) phase }\end{array}$ \\
\hline $\mathrm{Nd}_{0.253} \mathrm{Gd}_{0.747} \mathrm{Se}_{1.478}$ & $1500 / 5000 / 10$ & -135.0 & $\begin{array}{l}\text { Increasing amounts of second } \\
\text { (cubic) phase }\end{array}$ \\
\hline
\end{tabular}

TABLE 3-19

HOT-PRESSING REPRODUCIBILITY TRIALS

\begin{tabular}{c|c|c|c}
\hline $\begin{array}{c}\text { Sample } \\
\mathbf{7 9 5 8 - 9 7 -}\end{array}$ & $\begin{array}{c}\text { Density } \\
\left(\mathbf{g} / \mathbf{c m}^{3}\right)\end{array}$ & $\begin{array}{c}130^{\circ} \mathbf{C} / \mathbf{3 0}^{\circ} \mathbf{C} \text { Seebeck } \\
\mathbf{C o e f f i c i e n t}, \alpha \\
\left(\mu \mathbf{V} /{ }^{\circ} \mathbf{C}\right)\end{array}$ & $\begin{array}{c}\mathbf{2 3}^{\circ} \mathbf{C ~ R e s i s t i v i t y ,} \rho \\
(\mathbf{m} \Omega \text {-cm })\end{array}$ \\
\hline 1 & 6.62 & -93.0 & 5.50 \\
2 & 6.64 & -101.0 & 4.57 \\
3 & 6.68 & -105.0 & 3.01 \\
4 & 6.63 & -105.8 & 3.39 \\
5 & 6.67 & -107.4 & 4.72 \\
6 & 6.62 & -107.0 & 5.37 \\
7 & 6.65 & -108.0 & 5.49 \\
8 & 6.64 & -105.0 & 5.48 \\
9 & 6.64 & -105.0 & 5.94 \\
$\bar{X}$ & 6.64 & -104.1 & 4.83 \\
$\sigma$ & 0.021 & 4.64 & 1.02 \\
\hline
\end{tabular}


The examinations suggested a high degree of pre-hot-pressed material variability that was not detectable by chemical compositions or X-ray crystal structure examinations. Vapor pressure measurements appeared to be sensitive enough to detect sufficient mobile selenium in melted $\mathrm{NdSe}_{1.5-\mathrm{x}}$ to cause differences in measured thermoelectric properties. The vapor pressure of selenium over $\mathrm{NdSe}_{1.5-\mathrm{x}}$ at elevated temperatures appears to be related to the time at temperature and the $\mathrm{NdSe}_{1.5-\mathrm{x}}$ rate of cooling after melting. These data are in agreement with the work of Vickery and Muir (Ref. 3-1) on $\mathrm{Gd}_{2} \mathrm{Se}_{3}$, which suggests the formation of a monophase of $90 \% \mathrm{Gd}_{2} \mathrm{Se}_{3}$ and that GdSe is responsible for the high thermoelectric figure-of-merit of this material.

Figure 3-10 compares GA and 3M Company $\mathrm{NdSe}_{1.5-\mathrm{x}}$ element fabrication for fabricating $\mathrm{NdSe}_{1.5-x}$ elements. The $3 \mathrm{M}$ Company uses a cold press and sintering process, while GA uses a hot press process. Thermoelectric property measurements show that these differing processes produce elements whose thermoelectric properties are indistinguishable. Photomicrographs of GA material (Figs. 3-11 and 3-12) and the 3M Company material (Figs. 3-13 and 3-14) show the two microstructures to be comparable. The dark spots in the 3M Company material are pores. This can be expected in cold pressed and sintered material. Scanning electron microscopy photomicrographs of the two materials (Figs. 3-15 and 3-16) show that both materials are dense.

Table 3-20 lists and Table 3-21 summarizes the recent hot pressing trials of $\mathrm{NdSe}_{1.5-\mathrm{x}}$. Elements which were hot pressed from melted Method $2 \mathrm{NdSe}_{1.5-\mathrm{x}}$ were stronger than those which were hot pressed from unmelted material. Resistivities of $\mathrm{N}$ elements hot pressed at $1400^{\circ} \mathrm{C}$ and post-annealed at $1700^{\circ} \mathrm{C}$ were one to two orders of magnitude lower than elements which were not post-hot-press annealed. Thermoelectric properties of elements hot pressed from $\mathrm{NdSe}_{1.5-x}$ material prepared by Ames Laboratory or GA Method 2 were indistinguishable. The lowest resistivities of the hot pressed elements were from $\mathrm{NdSe}_{1.5-\mathrm{x}}$ which had been held at its melting temperature for $30 \mathrm{~min}$.

Additional hot pressing trials were made to determine if metal additives to diselenide $\mathrm{NdSe}_{1.5-\mathrm{x}}$ material during hot pressing would reduce its friability. Table 3-22 summarizes the results of these experiments. The results show that $1 \%$ additions of nickel and platinum increase the resistivity and lower the Seebeck coefficient of $\mathrm{NdSe}_{1.5-x}$ prepared by Method 2 which is hot pressed at $1400^{\circ} \mathrm{C}$. Additions of molybdenum, rhenium, chromium, $\mathrm{La}_{2} \mathrm{Se}_{3}, \mathrm{Gd}_{2} \mathrm{Se}_{3}$, carbon, and graphite had no significant influence on the thermoelectric properties of the hot-pressed $\mathrm{NdSe}_{1.5-x}$ elements. The effect of these additions on the mechanical properties of the element were qualitatively mixed. Some elements were stronger and less friable, some were less friable but weaker, and some showed no apparent change in mechanical properties.

\subsection{3. $\quad$ NdSe $_{1.5-x}$ Hot Pressing Summary}

Results of hot pressing trials for $\mathrm{NdSe}_{1.5-\mathrm{x}}$ prepared from both stoichiometric and diselenide starting materials can be summarized as follows:

1. The most consistent $\mathrm{NdSe}_{1.5-\mathrm{x}}$ with thermoelectric properties producing the best figure of merit came from melted material which was prepared by some variation of the Ames Laboratory diselenide process. 


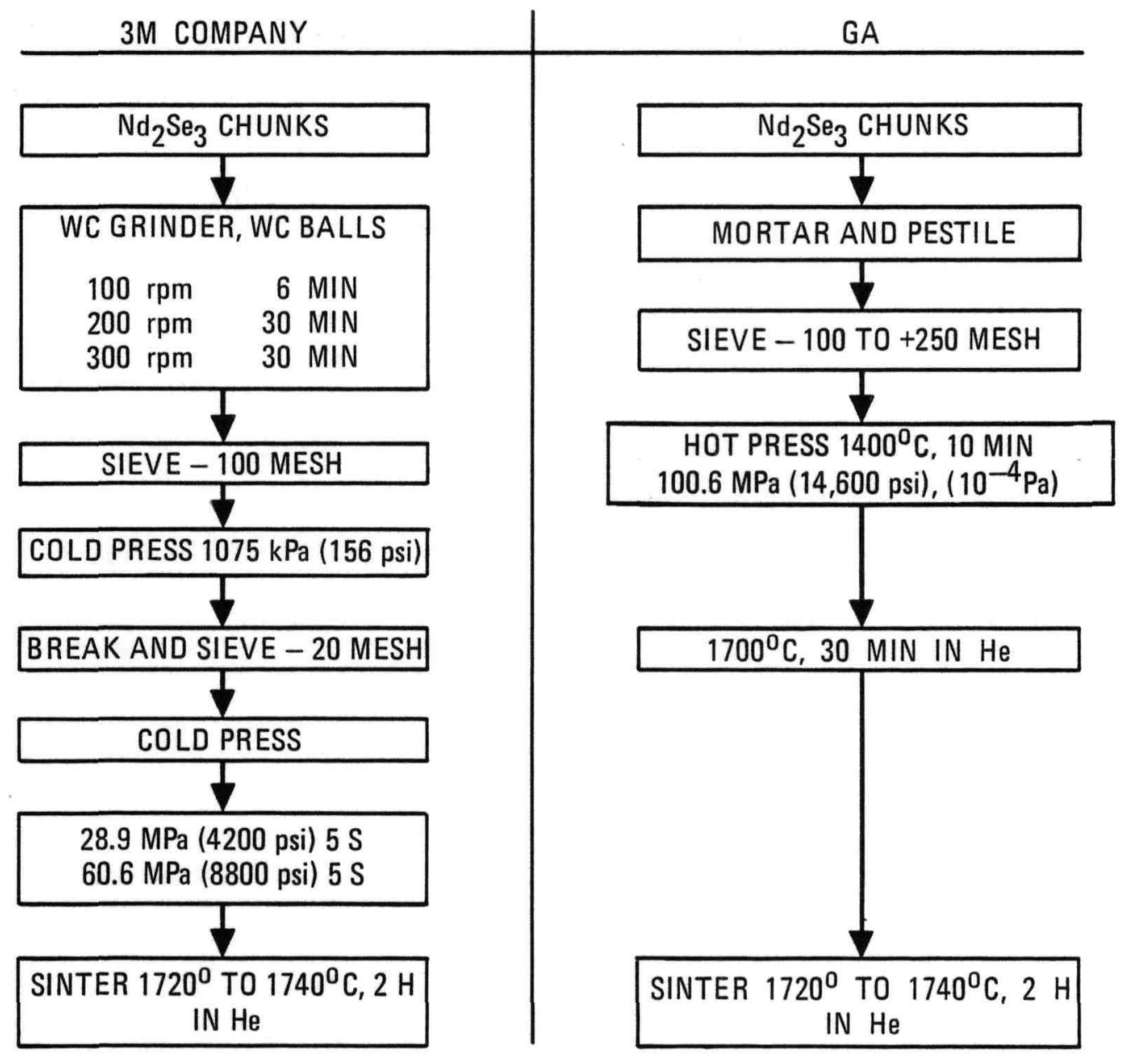

Fig. 3-10. Flowchart for element fabrication 


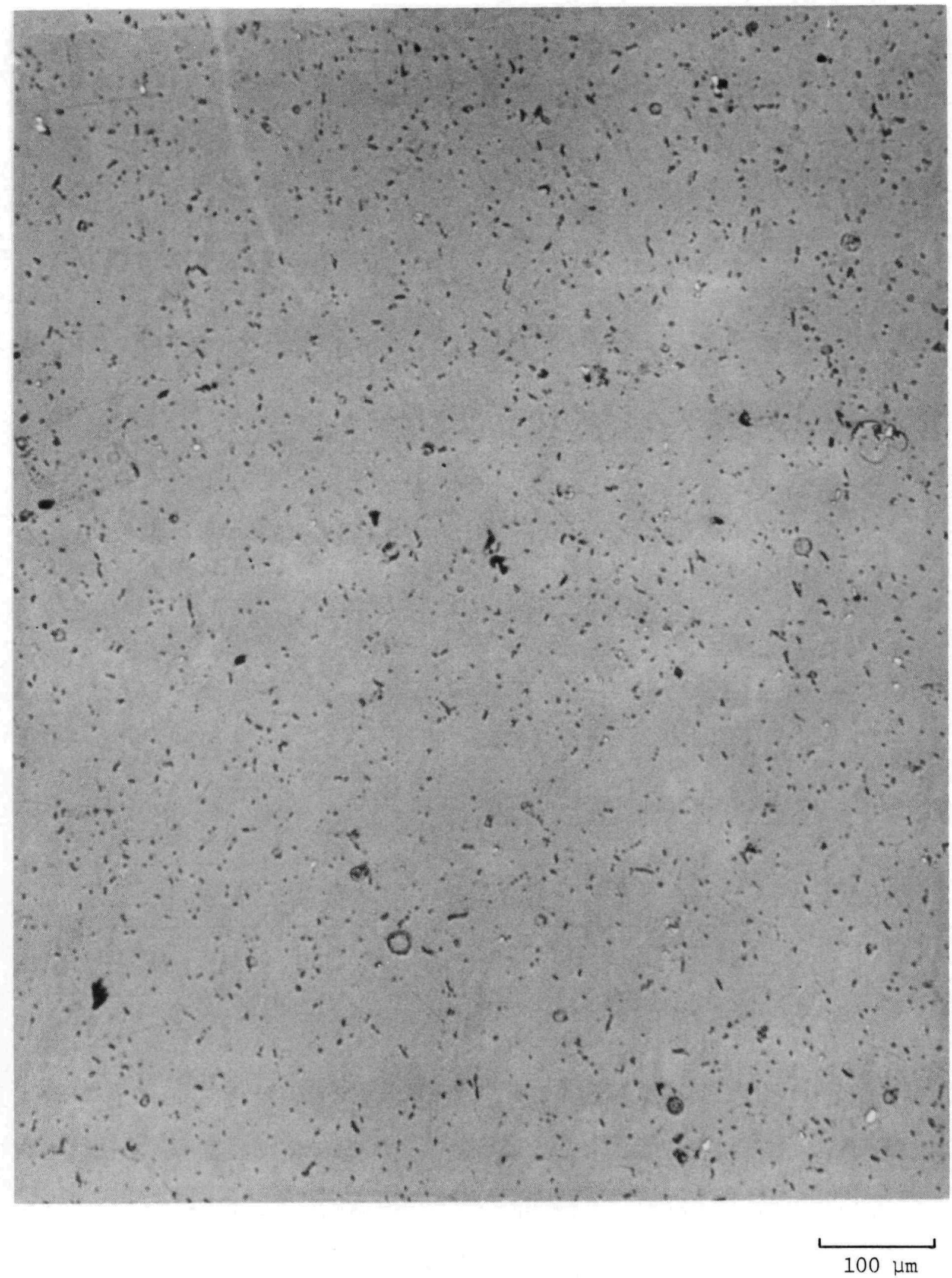

Fig. 3-11. Photomicrograph of $\mathrm{Nd} d_{2} S e_{3,3}$, hot pressed at $1400^{\circ} \mathrm{C}$ and post-heat treated at $1700^{\circ} \mathrm{C}$ 


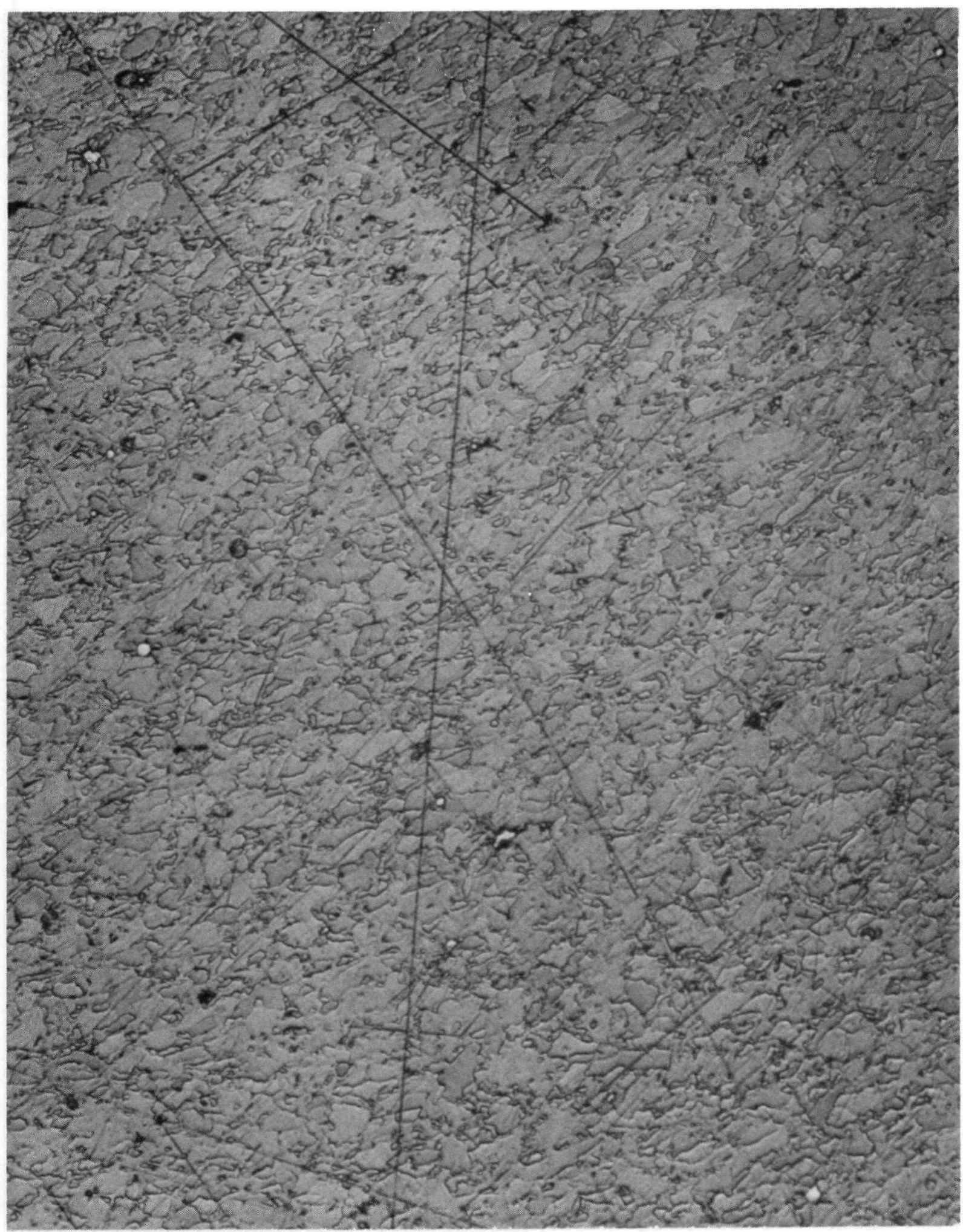

$100 \mu \mathrm{m}$

Fig. 3-12. Second photomicrograph of $\mathrm{Nd} \mathrm{d}_{2} \mathrm{Se} \mathrm{e}_{3,}$, hot pressed at $1400^{\circ} \mathrm{C}$ and post-heat treated at $1700^{\circ} \mathrm{C}$ 


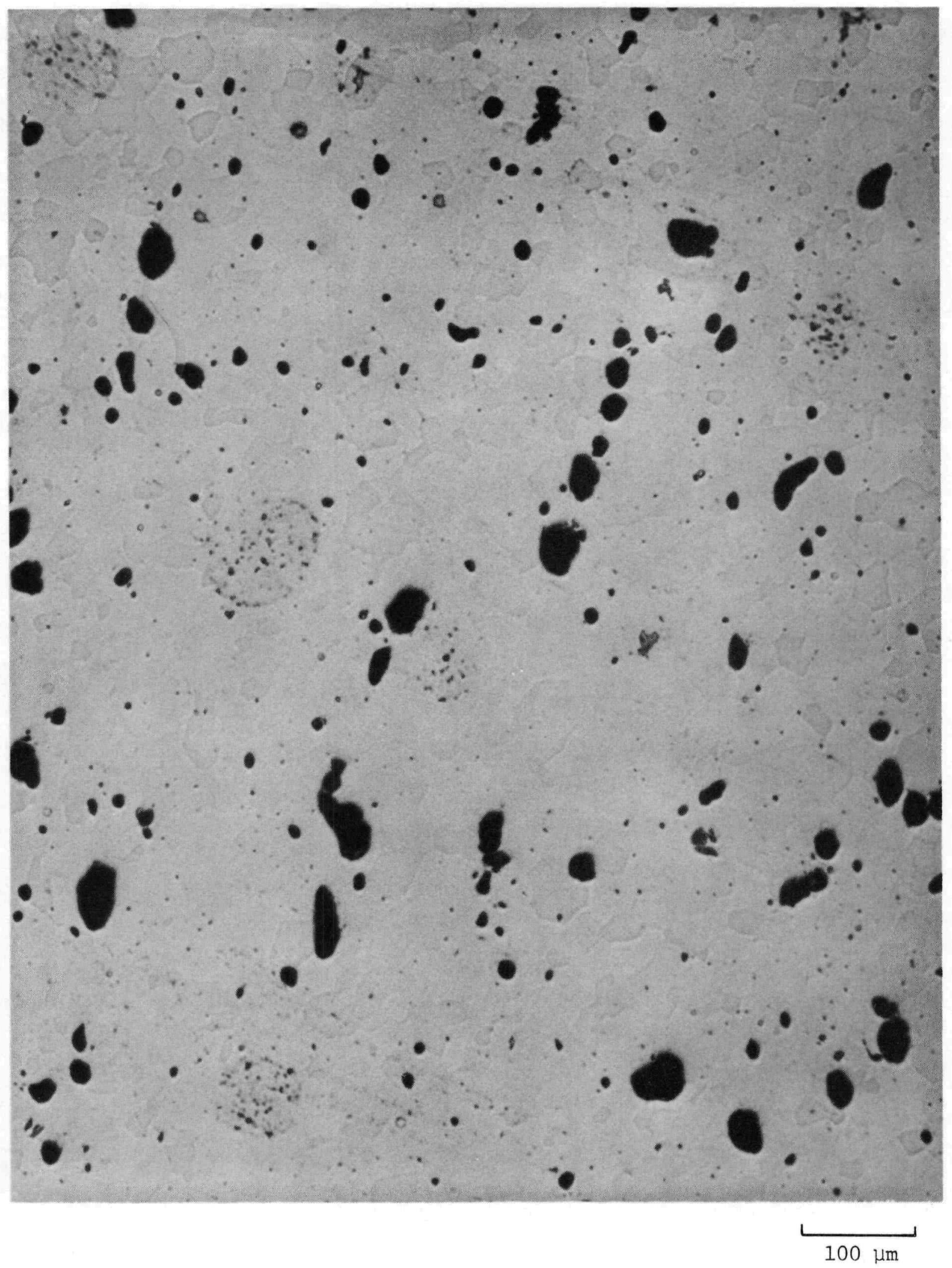

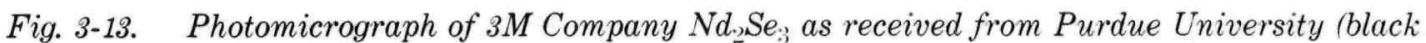
holes are pores) 


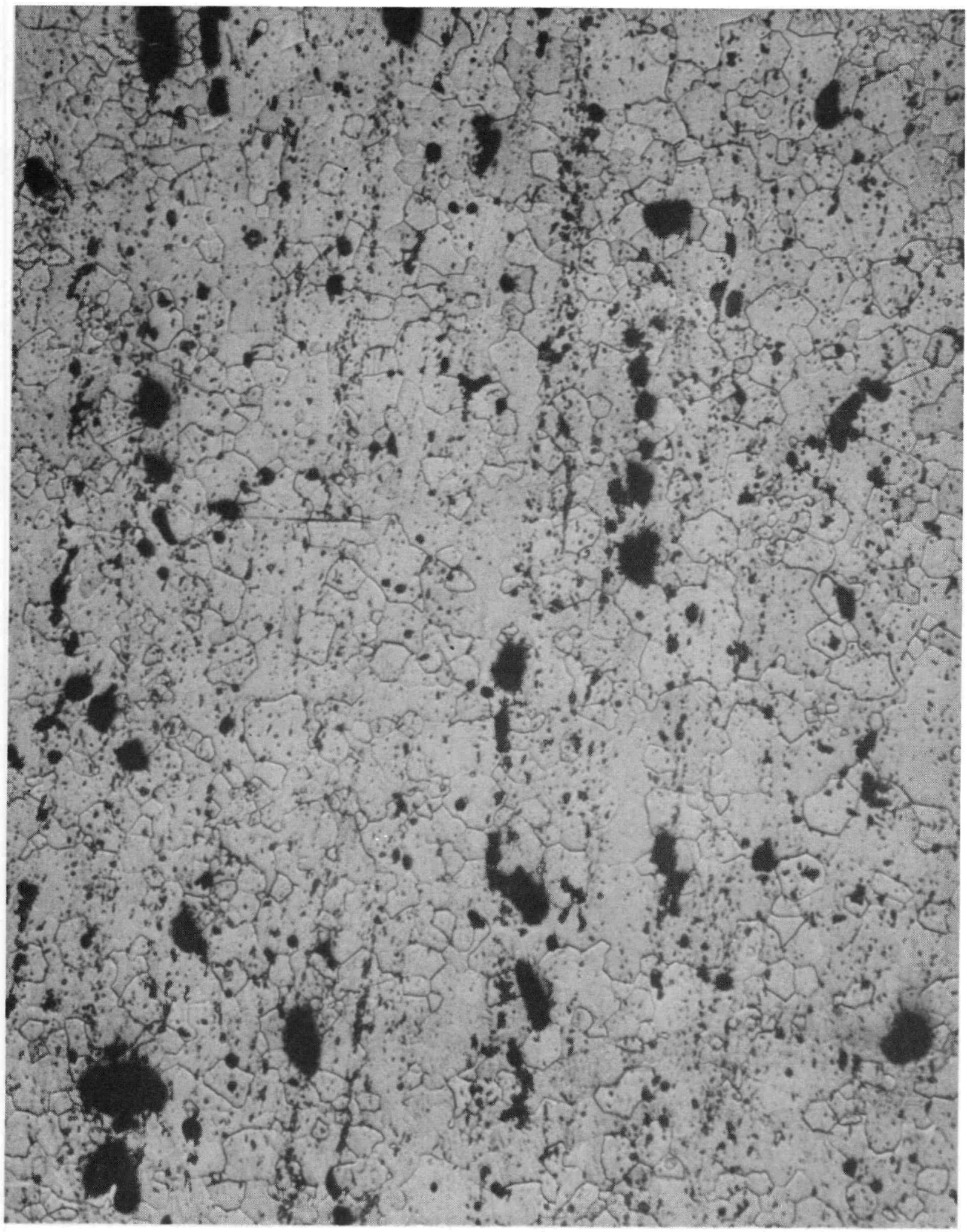

100 um

Fig. 3-14. Photomicrograph of etched 3M Company Nd.SS as received from Purdue University. Grain size is approximately comparable to GA material. 


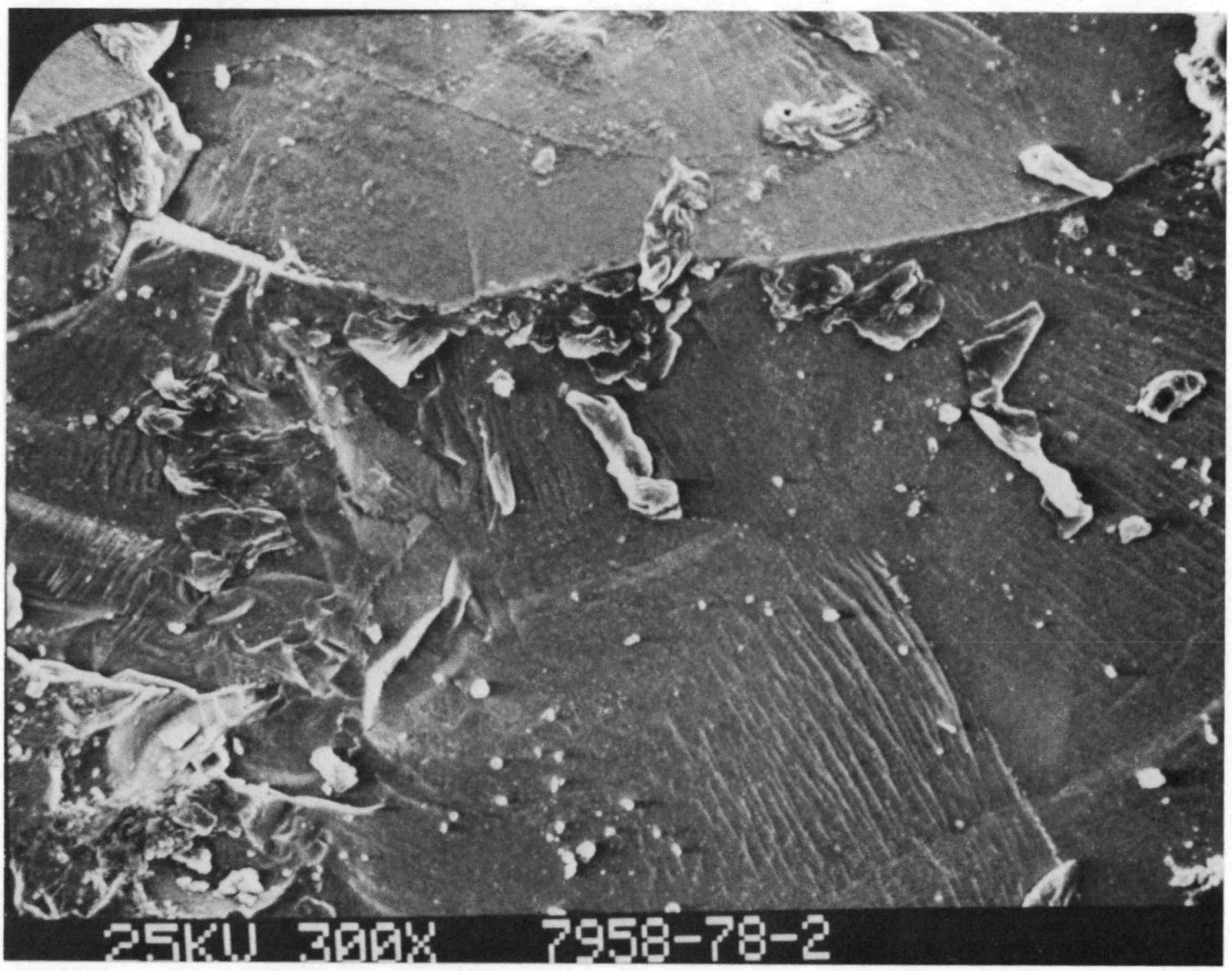

Fig. 3-15. Scanning electron microscopy photomicrograph of GA hot-pressed and annealed $\mathrm{Nd}_{2}$ $\mathrm{Se}_{3}$ showing very dense structure 


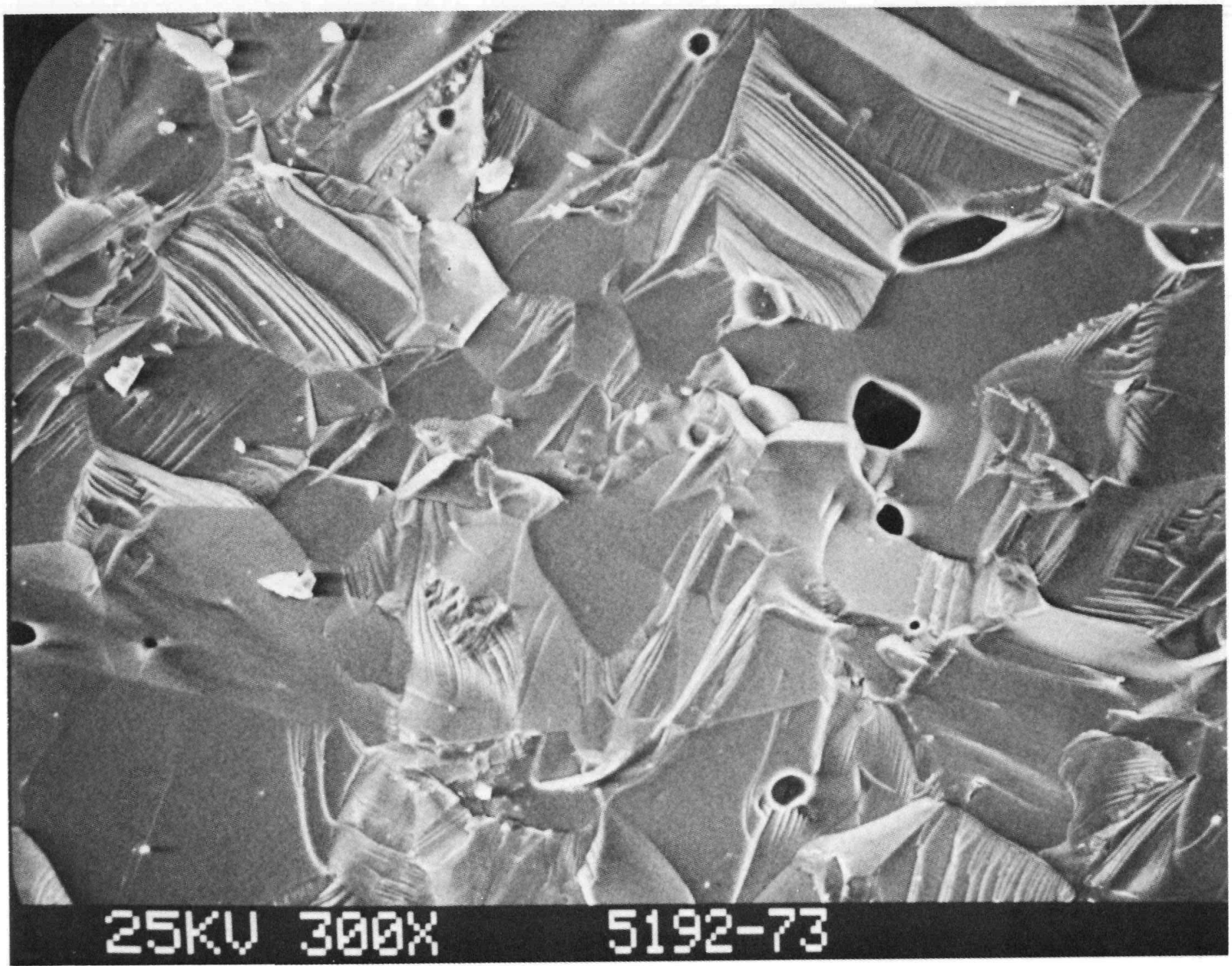

Fig. 3-16. Scanning electron microscopy photomicrograph of 3M Company cold-pressed and sintered $\mathrm{Nd}_{2} \mathrm{Se}_{3}$ as received from Purdue University 
TABLE 3-20

HOT PRESSING OF NdSe $\mathrm{N}_{1.5-\mathrm{x}}$

\begin{tabular}{|c|c|c|c|c|c|c|c|c|c|}
\hline \multirow{2}{*}{$\begin{array}{l}\text { Specimen } \\
\text { No. }\end{array}$} & \multirow[b]{2}{*}{$\begin{array}{l}\mathbf{N d}_{2} \mathbf{S e}_{3} \\
\text { Source }\end{array}$} & \multicolumn{3}{|c|}{ Hot Press } & \multicolumn{3}{|c|}{ Post-Heat Treatment } & \multirow{2}{*}{$\begin{array}{l}130^{\circ} \mathrm{C} / 30^{\circ} \mathrm{C} \\
\text { Seebeck } \\
\text { Coefficient, } \alpha \\
\left(\mu \mathrm{V} /{ }^{\circ} \mathrm{C}\right) \\
\end{array}$} & \multirow{2}{*}{$\begin{array}{c}23^{\circ} \mathrm{C} \text { Resistivity, } \rho \\
\text { (m } \Omega-\mathrm{cm})\end{array}$} \\
\hline & & $\begin{array}{l}\text { Temp } \\
\left({ }^{\circ} \mathrm{C}\right)\end{array}$ & $\begin{array}{c}\text { Pressure } \\
{[\mathrm{MPa} \text { (psi)] }}\end{array}$ & $\begin{array}{l}\text { Time } \\
\text { (min) }\end{array}$ & $\begin{array}{c}\text { Temp } \\
\left({ }^{\circ} \mathrm{C}\right)\end{array}$ & Gas & $\begin{array}{l}\text { Time } \\
(\min )\end{array}$ & & \\
\hline $7958-59-1$ & $7958-56^{(\mathrm{a})}$ & 1400 & $100.6(14,600)$ & 10 & - & - & - & -261 & 157.1 \\
\hline $7958-59-2$ & $7958-56^{(a)}$ & 1400 & $100.6(14,600)$ & 10 & 1700 & vac & 30 & -109 & - \\
\hline $7958-61-1$ & $7958-56^{(a)}$ & 1400 & $100.6(14,600)$ & 10 & 1700 & $\mathrm{He}$ & 30 & -129 & 5.85 \\
\hline $7958-61-2$ & $7958-58-1^{(b)}$ & 1400 & $100.6(14,600)$ & 10 & - & - & - & -229 & 418.8 \\
\hline $7958-67-1$ & $7958-58-2^{(b)}$ & 1400 & $100.6(14,600)$ & 10 & 1700 & vac & 30 & -133 & - \\
\hline $7958-67-2$ & $7958-58-2^{(b)}$ & 1400 & $100.6(14,600)$ & 10 & 1700 & $\mathrm{He}$ & 30 & -127 & 8.59 \\
\hline $7958-69-1$ & $7958-58-3^{(b)}$ & 1400 & $100.6(14,600)$ & 10 & 1800 & $\mathrm{He}$ & 30 & -103 & 4.65 \\
\hline $7958-73-2$ & $7958-63-2^{(c)}$ & 1350 & $100.6(14,600)$ & 10 & - & - & - & -319 & 141.0 \\
\hline $7958-74-1$ & $7958-63-2^{(c)}$ & 1400 & $100.6(14,600)$ & 10 & 1700 & $\mathrm{He}$ & 30 & -117 & - \\
\hline $7958-72-2$ & $7958-63-2^{(c)}$ & 1375 & $100.6(14,600)$ & 10 & 1800 & $\mathrm{He}$ & 120 & -104 & - \\
\hline $7958-78-2$ & $7958-78-1^{(c)}$ & 1400 & $100.6(14,600)$ & 10 & 1700 & $\mathrm{He}$ & 30 & -96 & 9.27 \\
\hline $7958-88$ & $7958-78-1^{(c)}$ & 1350 & $50.3 \quad(7,300)$ & 15 & 1700 & $\mathrm{He}$ & 30 & -138 & - \\
\hline $7958-84-1$ & $7958-84-1^{(c)}$ & 1400 & $100.6(14,600)$ & 10 & 1700 & $\mathrm{He}$ & 30 & -140 & - \\
\hline $7958-92-3$ & $7958-90^{(d)}$ & 1350 & $100.6(14,600)$ & 10 & 1700 & $\mathrm{He}$ & 30 & -114 & - \\
\hline $7958-94-2$ & $7958-90^{(d)}$ & 1400 & $100.6(14,600)$ & 10 & 1700 & $\mathrm{He}$ & 30 & -106 & - \\
\hline $7958-94-1$ & $7958-90^{(d)}$ & 1400 & $100.6(14,600)$ & 10 & 1700 & $\mathrm{He}$ & 30 & -97 & 7.88 \\
\hline $7958-97(1-9)$ & $7958-71-2^{(\mathrm{e})}$ & 1400 & $100.6(14,600)$ & 10 & 1700 & $\mathrm{He}$ & 30 & $-104^{(\mathrm{f})}$ & $4.83^{(f)}$ \\
\hline $7958-105 \mathrm{E}$ & $7958-105 \mathrm{D}^{(\mathrm{g})}$ & 1400 & $100.6(14,600)$ & 10 & 1700 & $\mathrm{He}$ & 30 & -75 & 1.95 \\
\hline $7958-106-2$ & $7958-105 \mathrm{D}^{(\mathrm{g})}$ & 1400 & $100.6(14,600)$ & 10 & 1700 & $\mathrm{He}$ & 30 & -78 & 2.50 \\
\hline $7958-106-3$ & $7958-105 C^{(h)}$ & 1400 & $100.6(14,600)$ & 10 & 1700 & $\mathrm{He}$ & 30 & -93 & 4.59 \\
\hline
\end{tabular}

(a) Unmelted $\mathrm{Nd}_{2} \mathrm{Se}_{3}$ prepared by Ames Laboratory.

(b) Ames Laboratory $\mathrm{Nd}_{2} \mathrm{Se}_{3}$ melted 1 min at GA in argon.

(c) General Atomic $\mathrm{Nd}_{2} \mathrm{Se}_{3}$ melted $1.5 \mathrm{~min}$ at $\mathrm{GA}$ in argon.

(d) General Atomic $\mathrm{Nd}_{2} \mathrm{Se}_{3}$ melted in 3 min at GA in argon.

(e) Ames Laboratory $\mathrm{Nd}_{2} \mathrm{Se}_{3}$ melted at Ames Laboratory (see reproducibility runs).

(f) Average of nine samples.

${ }^{(\mathrm{g})}$ General Atomic $\mathrm{Nd}_{2} \mathrm{Se}_{3}$ melted $30 \mathrm{~min}$ in helium at GA.

(h) General Atomic $\mathrm{Nd}_{2} \mathrm{Se}_{3}$ melted 10 min in argon. 


\section{TABLE 3-21 \\ SUMMARY \\ HOT PRESS Nd $\mathrm{Ne}_{3}$ RESULTS $^{(\mathrm{a})}$}

\begin{tabular}{|c|c|c|}
\hline & $\begin{array}{c}130^{\circ} \mathrm{C} / 30^{\circ} \mathrm{C} \\
\text { Seebeck } \\
\text { Coefficient, } \alpha \\
\left(\mu \mathrm{V} /{ }^{\circ} \mathrm{C}\right)\end{array}$ & $\begin{array}{l}23^{\circ} \mathrm{C} \text { Resistivity, } \rho \\
(\mathrm{m} \Omega-\mathrm{cm})\end{array}$ \\
\hline Unmelted Ames Laboratory $\mathrm{Nd}_{2} \mathrm{Se}_{3}$, hot pressed with no-post-heat treatment & -261 & 157.1 \\
\hline $\begin{array}{l}1 \text { min melted Ames Laboratory } \mathrm{Nd}_{2} \mathrm{Se}_{3} \text {, hot pressed with no post-heat } \\
\text { treatment }\end{array}$ & -229 & 418.8 \\
\hline $\begin{array}{l}1.5 \text { min melted } \mathrm{GA} \mathrm{Nd}_{2} \mathrm{Se}_{3} \text {, hot pressed with no post-heat } \\
\text { treatment }\end{array}$ & -319 & 141.0 \\
\hline $\begin{array}{l}\text { Unmelted Ames Laboratory } \mathrm{Nd}_{2} \mathrm{Se}_{3} \text {, hot pressed with } 1700^{\circ} \mathrm{C}, 30 \text {-min } \\
\text { helium post-heat treatment }\end{array}$ & -129 & 5.85 \\
\hline $\begin{array}{l}1 \text { min melted Ames Laboratory } \mathrm{Nd}_{2} \mathrm{Se}_{3} \text {, hot pressed with } 1700^{\circ} \mathrm{C} \text {, } \\
30 \text { min helium post-heat treatment }\end{array}$ & -115 & 6.62 \\
\hline $\begin{array}{l}1.5 \text { to } 3 \text { min melted } \mathrm{GA} \mathrm{Nd}_{2} \mathrm{Se}_{3} \text {, hot pressed with } 1700^{\circ} \mathrm{C} \text {, } \\
30 \text { min helium post-heat treatment }\end{array}$ & -115 & 8.57 \\
\hline $\begin{array}{l}\text { Ames Laboratory } \mathrm{Nd}_{2} \mathrm{Se}_{3} \text { melted at Ames Laboratory, hot pressed with } \\
1700^{\circ} \mathrm{C} \text {, } \\
30 \text { min helium post-heat treatment }\end{array}$ & -104 & 4.83 \\
\hline $\begin{array}{l}10 \text { min melted } \mathrm{GA} \mathrm{Nd}_{2} \mathrm{Se}_{3} \text {, hot pressed with } 1700^{\circ} \mathrm{C} \text {, } \\
30 \text { min helium pst-heat treatment }\end{array}$ & -93 & 4.59 \\
\hline $\begin{array}{l}30 \text { min melted GA } \mathrm{Nd}_{2} \mathrm{Se}_{3} \text { hot pressed with } 1700^{\circ} \mathrm{C} \text {, } \\
30 \text { min helium post-heat treatment }\end{array}$ & -77 & 2.23 \\
\hline
\end{tabular}

(a) Results may be averages of two or more samples. 
TABLE 3-22

EFFECT OF HOT PRESSING ADDITIVES ON

THE THERMAL ELECTRIC PROPERTIES OF NdSe $\mathrm{e}_{1.5-\mathrm{x}}$

\begin{tabular}{|c|c|c|c|c|c|c|c|c|c|}
\hline \multirow[b]{2}{*}{$\begin{array}{c}\text { Specimen } \\
\text { No. }\end{array}$} & \multirow[b]{2}{*}{$\begin{array}{l}\mathbf{N d}_{2} \mathbf{S e}_{3} \\
\text { Source }\end{array}$} & \multirow[b]{2}{*}{$\begin{array}{c}\text { Additive/ } \\
\text { wt } \%\end{array}$} & \multicolumn{2}{|c|}{$\begin{array}{c}\text { Hot Pressing } \\
10 \mathrm{~min} \text { at }\end{array}$} & \multicolumn{3}{|c|}{$\begin{array}{l}\text { Post-Heat } \\
\text { Treatment }\end{array}$} & \multirow{2}{*}{$\begin{array}{c}130^{\circ} \mathrm{C} / 30^{\circ} \mathrm{C} \\
\text { Seebeck } \\
\text { Coefficient, } \alpha \\
\left(\mu \mathrm{V} /{ }^{\circ} \mathrm{C}\right) \\
\end{array}$} & \multirow[b]{2}{*}{$\begin{array}{c}23^{\circ} \mathrm{C} \text { Resistivity, } \\
(\mathrm{m} \Omega-\mathrm{cm})\end{array}$} \\
\hline & & & $\begin{array}{l}\text { Temp } \\
\left({ }^{\circ} \mathrm{C}\right)\end{array}$ & $\begin{array}{c}\text { Pressure } \\
{[\mathrm{MPa}(\mathrm{psi})]}\end{array}$ & $\begin{array}{l}\text { Temp } \\
\left({ }^{\circ} \mathrm{C}\right)\end{array}$ & Gas & $\begin{array}{l}\text { Time } \\
(\mathrm{min})\end{array}$ & & \\
\hline $7958-59-1$ & $7958-56^{(\mathrm{a})}$ & None & 1400 & $100.6(14,600)$ & - & - & - & -261 & 157 \\
\hline $7958-60-1$ & $7958-50^{\text {(a) }}$ & $\mathrm{Ni} / 1$ & 1400 & $100.6(14,600)$ & - & - & - & -10 & $>1000$ \\
\hline $7958-60-2$ & $7958-56^{(\mathrm{a})}$ & $\mathrm{Ni} / 1$ & 1400 & $100.6(14,600)$ & - & - & - & +115 & $>1000$ \\
\hline $7958-61-3$ & $7958-58-1^{(b)}$ & $\mathrm{Ni} / 1$ & 1400 & $100.6(14,600)$ & - & - & - & -261 & 755 \\
\hline $7958-72-2$ & $7958-63-2^{(c)}$ & $\mathrm{Ni} / 1$ & 1400 & $100.6(14,600)$ & - & - & - & -31 & - \\
\hline $7958-78-2$ & $7958-78-1^{(c)}$ & None & 1400 & $100.6(14,600)$ & 1700 & $\mathrm{He}$ & 30 & -96 & 9.27 \\
\hline $7958-79-2$ & $7958-78-1^{(c)}$ & $\mathrm{Mo} / 2$ & 1400 & $100.6(14,600)$ & 1700 & $\mathrm{He}$ & 30 & -118 & 13.07 \\
\hline $7958-74-2$ & $7958-63-2^{(c)}$ & $\mathrm{Mo} / 25$ & 1400 & $100.6(14,600)$ & 1700 & $\mathrm{He}$ & 30 & -114 & 5.54 \\
\hline $7958-79-1$ & $7958-78-1^{(\mathrm{c})}$ & Graphite/0.1 & 1400 & $100.6(14,600)$ & 1700 & $\mathrm{He}$ & 30 & -103 & 5.52 \\
\hline $7958-82-1$ & $7958-78-1^{(c)}$ & Carbon/1 & 1400 & $100.6(14,600)$ & 1700 & $\mathrm{He}$ & 30 & -106 & - \\
\hline $7958-81-1$ & $7958-78-1^{(c)}$ & $\mathrm{Re} / 1$ & 1400 & $100.6(14,600)$ & 1700 & $\mathrm{He}$ & 30 & -101 & - \\
\hline $7958-81-2$ & $7958-78-1^{(c)}$ & $\mathrm{Pt} / 1$ & 1400 & $100.6(14,600)$ & 1700 & $\mathrm{He}$ & 30 & -87.6 & $>600$ \\
\hline $7958-93-1$ & $7958-90^{(\mathrm{d})}$ & $\mathrm{Cr} / 5$ & 1400 & $100.6(14,600)$ & 1700 & $\mathrm{He}$ & 30 & -116 & - \\
\hline $7958-93-2$ & $7958-90^{(d)}$ & $\mathrm{La}_{2} \mathrm{~S}_{3} / 5$ & 1400 & $100.6(14,600)$ & 1700 & $\mathrm{He}$ & 30 & -123 & - \\
\hline $7958-93-3$ & $7958-90^{(d)}$ & $\mathrm{Gd}_{2} \mathrm{Se}_{3} / 5$ & 1400 & $100.6(14,600)$ & 1700 & $\mathrm{He}$ & 30 & -98.6 & - \\
\hline
\end{tabular}

(a)Ames Laboratory $\mathrm{Nd}_{2} \mathrm{Se}_{3}$ unmelted.

(b) Ames Laboratory $\mathrm{Nd}_{2} \mathrm{Se}_{3}$ melted $1 \mathrm{~min}$ in argon.

(c) General Atomic $\mathrm{Nd}_{2} \mathrm{Se}_{3}$ melted $1.5 \mathrm{~min}$ in argon.

(d) General Atomic $\mathrm{Nd}_{2} \mathrm{Se}_{3}$ melted $3 \mathrm{~min}$ in argon. 
2. Post-hot-press annealing at $1700^{\circ} \mathrm{C}$ for 30 min reduces the electrical resistivity of hot pressed $\mathrm{NdSe}_{1.5-\mathrm{x}}$.

3. The use of additives to improve the mechanical properties of the hot pressed element will, in the case of nickel or platinum, ruin the thermoelectric properties of the $\mathrm{N}$-type $\mathrm{NdSe}_{1.5-\mathrm{x}}$. Additives which do not adversely affect the thermoelectric properties of the hot pressed element still may not improve its mechanical properties.

\subsection{N-ELEMENT HOT CAP JOINING STUDIES}

$\mathrm{Nd}_{2} \mathrm{Se}_{3}$ was found to have a high coefficient of thermal expansion (as shown in Table 3-23) and a high modulus of elasticity. It also has a low thermal conductivity. These properties make this material thermal shock sensitive and account for the friability experienced when it is hot pressed. It is also a major problem which must be overcome when selecting a method of metallurgically joining an electrical conductor to this material.

First attempts to make a hot-cap-to-NdSe ${ }_{1.5-x}$ joint used a molybdenum or W-Re wire mesh that was hot pressed in place during $\mathrm{NdSe}_{1.5-x}$ element formation, as shown in Fig. 3-17. The thermal shock sensitivity of the $\mathrm{NdSe}_{1.5-x}$, combined with the significant differences in thermal expansion between the two materials, resulted in cracks in the element, as shown in Fig. 3-17. Efforts were made to overcome this weakness by making a graded $\mathrm{Mo} / \mathrm{Nd}_{2} \mathrm{Se}_{3}$ zone. The graded zone permitted the fabrication of an element with a wire-mesh-bonded hot cap. Photomicrographic examination of the graded zone and mesh (Fig. 3-18) showed the generation of multiple cracks but no crack which totaliy traversed the graded zone. Strengthening the joint by adding molybdenum and making a graded joint improved the crack resistance of the graded zone but shifted element failure to below the graded zone, as shown in Fig. 3-19. Clearly, satisfactory element-tohot-cap joints can only be made if the materials are chemically compatible at their temperature of use, accommodation for thermal expansion differences are built into the joint, and diffusion problems, such as Kirkendall separation, do not occur with time.

Compatibility tests of $\mathrm{NdSe}_{1.5-\mathrm{x}}$ in contact with nickel, tantalum, niobium, and gold from $800^{\circ}$ to $1070^{\circ} \mathrm{C}$ were conducted to select potential hot-cap materials. The results of these trials, as shown in Table 3-24, show MoRe and tantalum to have no apparent reaction with $\mathrm{Nd}_{2} \mathrm{Se}_{3}$ either as a braze alloy or in diffusion bonding. These materials have no obvious corrosive interaction. Direct contact of nickel against $\mathrm{NdSe}_{1.5-\mathrm{x}}$ continues to be questionable.

Differential thermal expansion between materials always exists but should be minimized in any brittle-to-ductile material joint. Measurements of the thermal expansion of a hot-pressed $\mathrm{NdSe}_{1.5-x}$ element (Table 3-23) show that the coefficient of thermal expansion of $\mathrm{Nd}_{2} \mathrm{Se}_{3}$ is approximately $17.5 \times 10^{6} /{ }^{\circ} \mathrm{C}$ and is linear. Being chemically compatible and close in thermal expansion, gold was a prime candidate for use in joining $\mathrm{NdSe}_{1.5-\mathrm{x}}$ to potential hot-cap materials.

Several hot-cap-to-NdSe $e_{1.5-x}$ joints were considered in addition to the wire mesh plus a metal-NdSe $\mathrm{N}_{1.5}$ graded zone already discussed. Figures 3-20 through 3-22 show these schematically. Some satisfactory joints were made by diffusion-bonding thin foil gold to $\mathrm{NdSe}_{1.5-\mathrm{x}}$. This was, in turn, tack-welded to nickel hot and cold caps. This joint was destructively examined and found satisfactory. This was the joint selected to prepare elements and couples. All recent N-type element cap joints were made by metallizing 
TABLE 3-23

$\mathrm{Nd}_{2} \mathrm{Se}_{3}$ THERMAL EXPANSION

\begin{tabular}{|c|c|c|c|}
\hline Sample No. & Sample Source & $\begin{array}{c}\mathbf{C T E}^{(\mathrm{a})} \text { at } \\
\text { Room Temperature } \\
\text { to } 500^{\circ} \mathrm{C} \\
\left(10^{-6}{ }^{\circ} \mathrm{C}\right)\end{array}$ & $\begin{array}{c}\mathrm{CTE}^{(\mathrm{a})} \text { at } \\
\text { Room Temperature } \\
\text { to } 900^{\circ} \mathrm{C} \\
\left(10^{-6}{ }^{\circ} \mathrm{C}\right)\end{array}$ \\
\hline $\begin{array}{l}7958-97-1-1 \\
7958-97-1-2 \\
5192-73-1-1 \\
5192-73-1-2 \\
316 \text { stainless steel } \\
\\
\text { Ref. data } \\
\text { ASM handbook }\end{array}$ & $\begin{array}{c}\text { GA } \\
\text { GA } \\
\text { 3M Company } \\
\text { 3M Company } \\
\text { Commercial }\end{array}$ & $\begin{array}{c}17.60 \\
16.58 \\
16.20 \\
15.80 \\
19.28 \\
19.16 \\
18.51 \\
\text { (to } 649^{\circ} \mathrm{C} \text { ) }\end{array}$ & $\begin{array}{c}17.94 \\
17.14 \\
17.12 \\
16.75 \\
20.06 \\
19.52 \\
19.95 \\
\text { (to } 816^{\circ} \mathrm{C} \text { ) }\end{array}$ \\
\hline
\end{tabular}

(a)Coefficient of thermal expansion. 


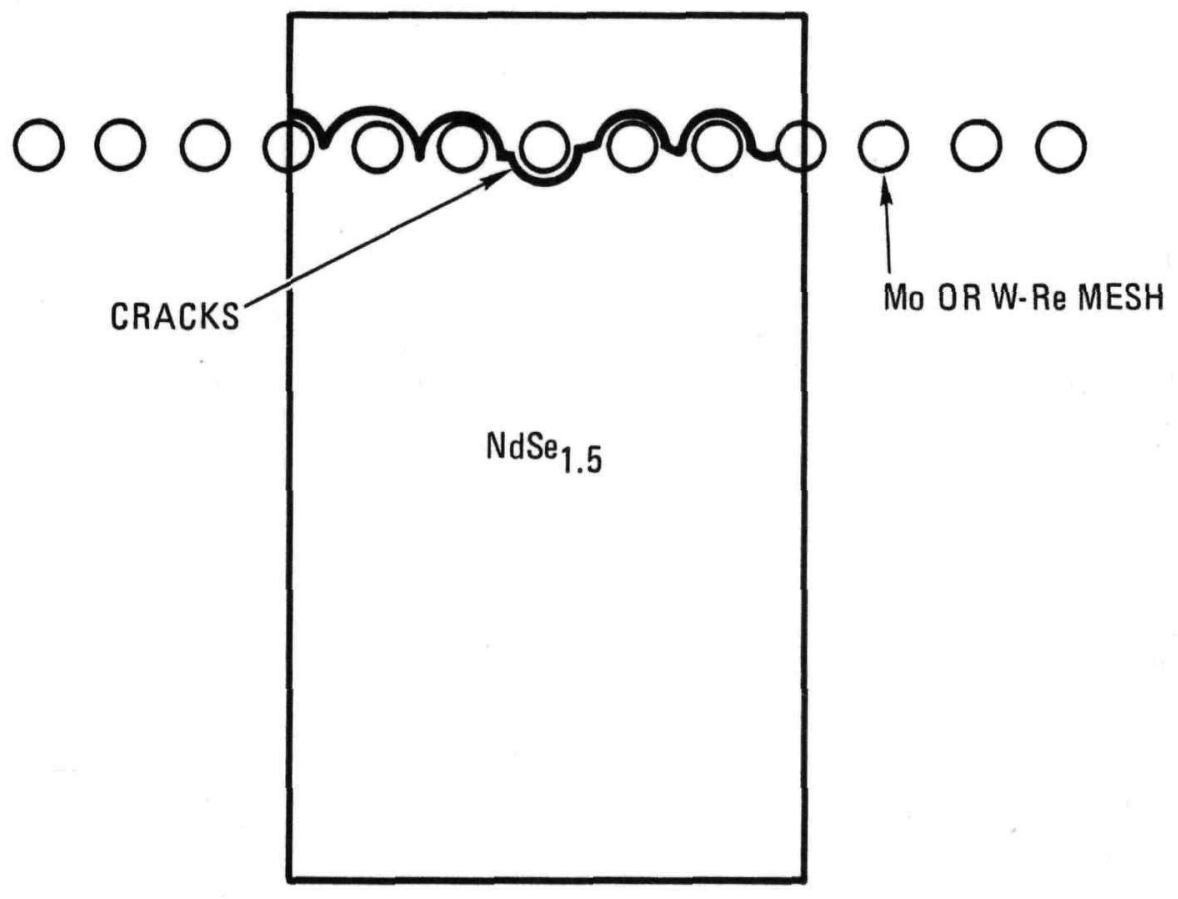

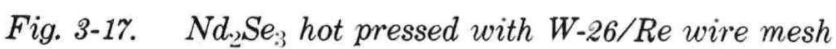




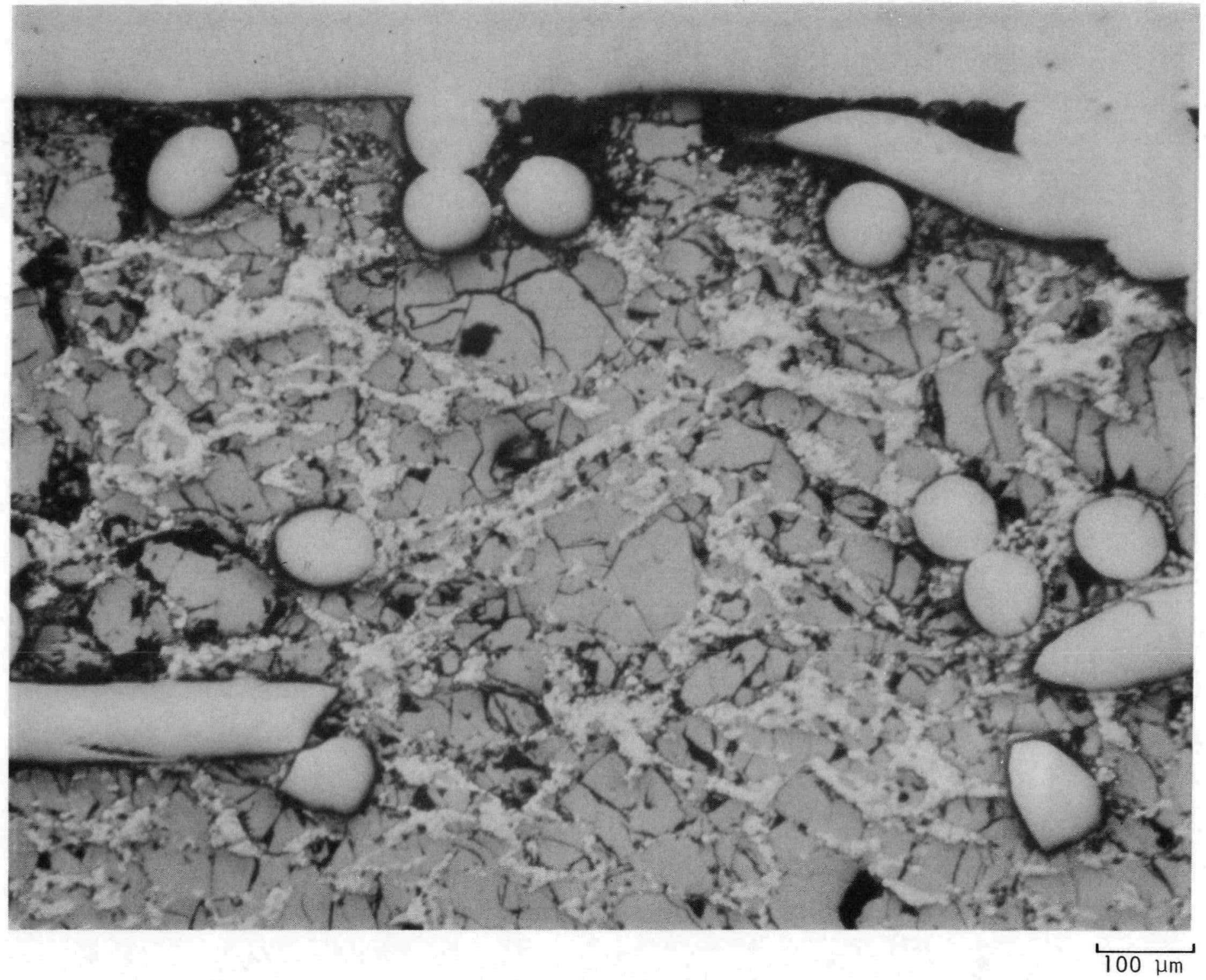

Fig. 3-18. Photomicrograph of the graded $\mathrm{Mo} / \mathrm{Nd} \mathrm{d}_{2} \mathrm{Se}$ and $\mathrm{W}$-26/Re mesh joint of $\mathrm{N}$-type element 7958-84-1 


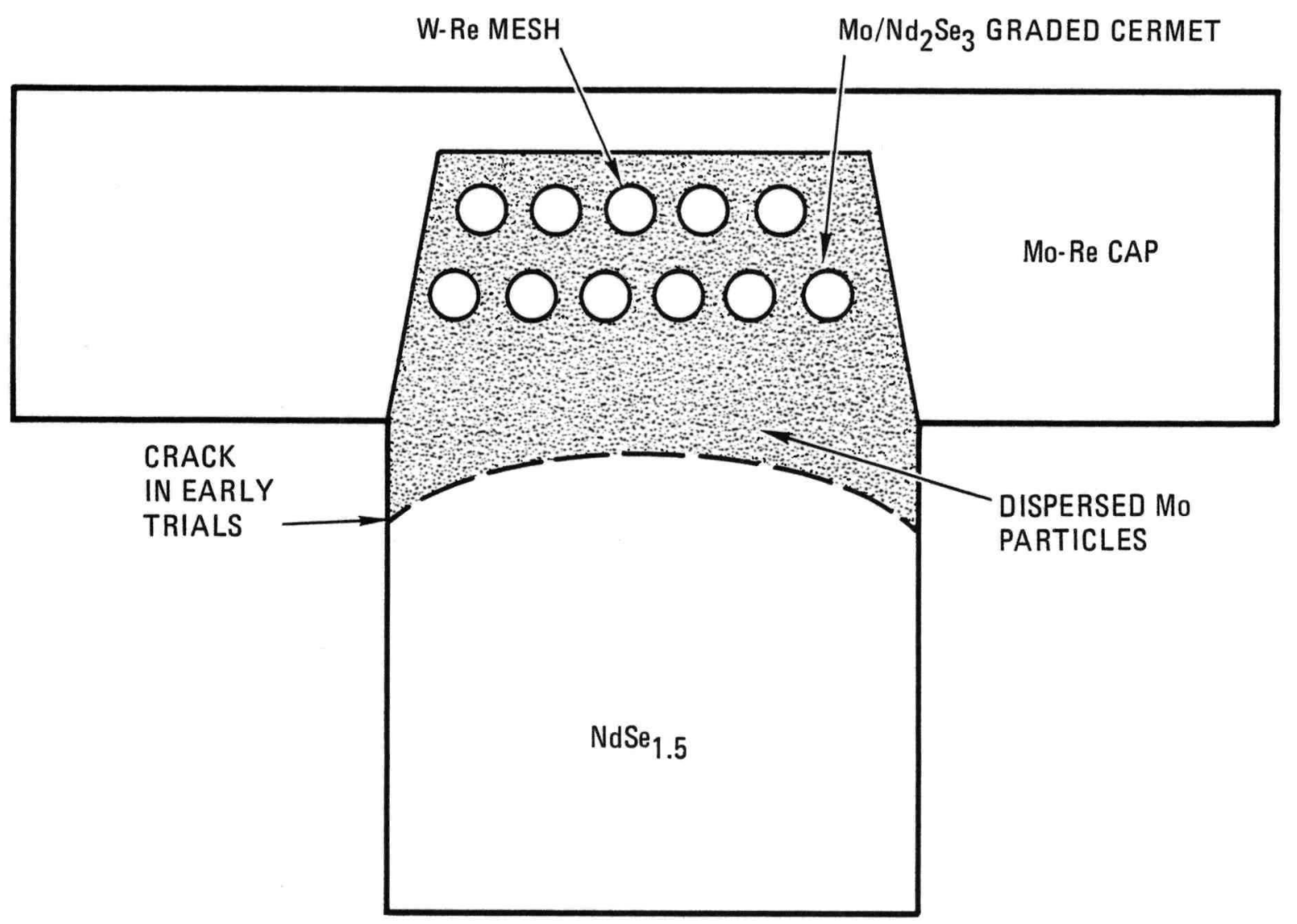

Fig. 3-19. $\quad \mathrm{Nd}_{2} \mathrm{Se}_{3}$ hot pressed with a Mo-Re cap 
TABLE 3-24 COMPATIBILITY TESTS

\begin{tabular}{|c|c|c|c|c|c|c|c|}
\hline & $\begin{array}{l}\text { Test } \\
\text { No. }\end{array}$ & $\begin{array}{c}\mathrm{Nd}_{2} \mathrm{Se}_{3} \\
\text { Sample No. }\end{array}$ & Material 1 & Results & Material 2 & Results & $\begin{array}{c}\text { Temp/Time/Gas } \\
\left({ }^{\circ} \mathbf{C} / \mathbf{h} /\right)\end{array}$ \\
\hline & $7958-76-1$ & $7958-62-1$ & $270 \mathrm{Ni}$ & Ni embrittled & $205 \mathrm{Ni}$ & Reaction noted & $820 / 22 / 0.5$ atmosphere $\mathrm{He}$ \\
\hline & $7958-76-2$ & $7958-70-2$ & $270 \mathrm{Ni}$ & Ni embrittled & $\begin{array}{l}50 / 50 \\
\mathrm{Mo} / \mathrm{Re}\end{array}$ & No reaction & $\begin{array}{l}800 \text { to } 850 / 23 / 0.5 \text { atmosphere } \\
\mathrm{Ar}\end{array}$ \\
\hline & $7958-77-3$ & $7958-72-2$ & Ta foil & No reaction & $\mathrm{Nb}$ foil & $\begin{array}{l}\text { Cap bluish overall, } \\
\text { no reaction }\end{array}$ & $820 / 62 / \mathrm{Ar}$ \\
\hline & $7958-77-4$ & $7958-73-1$ & Ta foil & No reaction & $\mathrm{Nb}$ foil & $\begin{array}{l}\text { Cap bluish overall, } \\
\text { no reaction }\end{array}$ & $820 / 21 / \mathrm{Ar}$ \\
\hline & $7958-80-5$ & $7958-70-1$ & MoRe & No reaction & $\mathrm{Nb}$ foil & $\begin{array}{l}\text { System black } \\
\text { neobium brittle }\end{array}$ & $820 / 66 / \mathrm{Ar}$ \\
\hline & $7958-80-6$ & $5192-73-2$ & $270 \mathrm{Ni}$ & Reaction not certain & MoRe & No reaction & $845 / 25 / \mathrm{Ar}$ \\
\hline & \multicolumn{7}{|c|}{ (Samples wrapped in tantalum to remove $\mathrm{O}_{2}$ in the specimens that follow) } \\
\hline & $7958-87-7$ & $5192-73-2$ & $270 \mathrm{Ni}$ & No reaction & MoRe & No reaction & $850 / 112 / \mathrm{Ar}$ \\
\hline & $7958-87-8$ & $7958-70-1$ & $270 \mathrm{Ni}$ & No reaction & MoRe & No reaction & 845 to $850 / 92 / \mathrm{Ar}$ \\
\hline & $7958-89-1$ & $7958-61-2$ & $\mathrm{Au} / 316 \mathrm{SS}$ & Bonded, no corrosion & $\mathrm{Au} / \mathrm{Mo}$ & Bonded, no corrosion & $1070 / 5$ to $7 \mathrm{~min} /$ vacuum \\
\hline
\end{tabular}




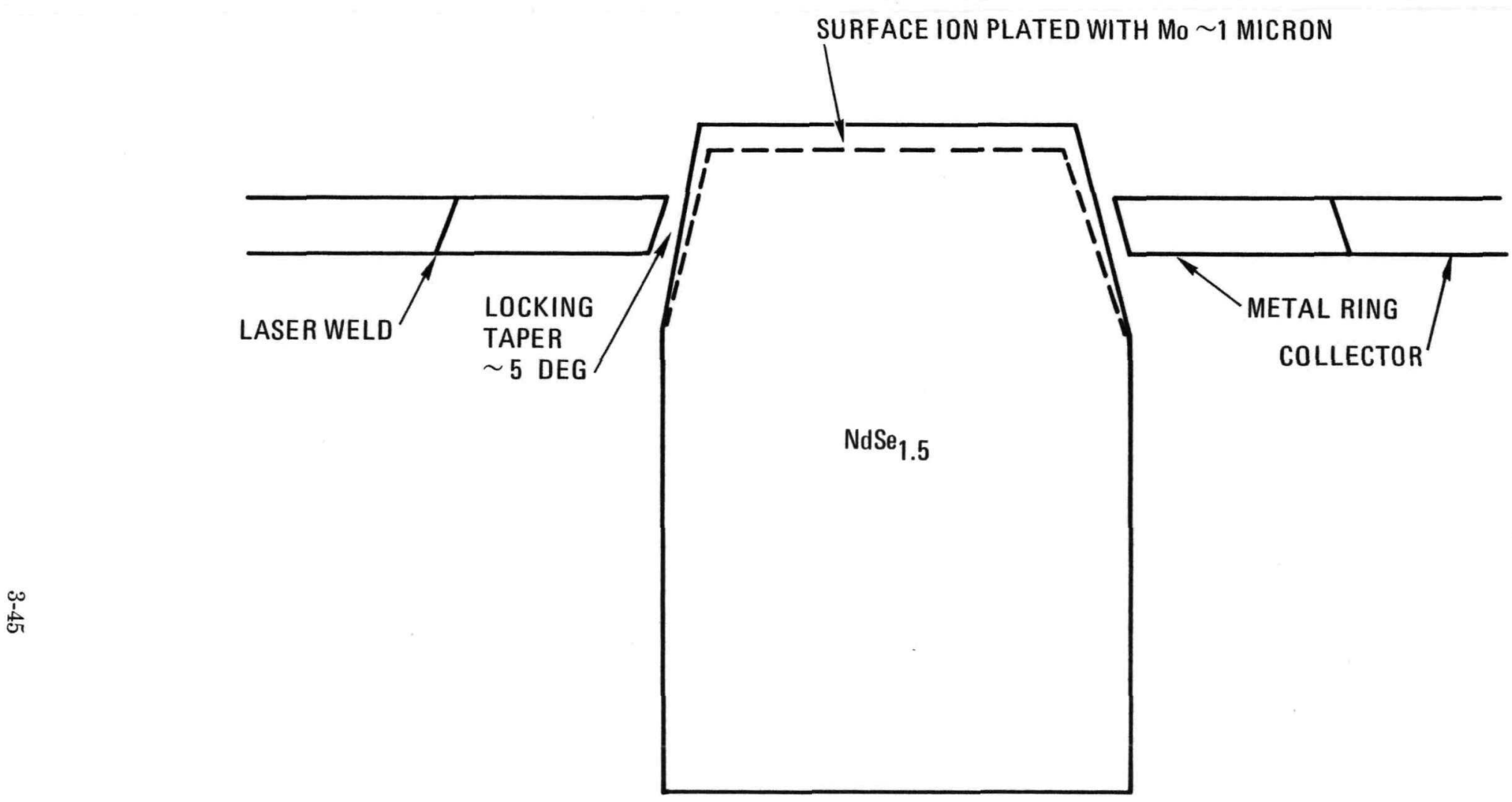

- CONCEPT INITIALLY DEVELOPED WITH SiGe AND Mo

- COMPONENTS CAN BE JOINED WITH A DIFFERENCE IN $\Delta T$

- JOINT CAN ALSO BE BRAZED

- $\mathrm{NdSe}_{1.5}$ IS HELD IN COMPRESSION 
$\mathrm{NdSe}_{1.5}$ SURFACE ION PLATED

WITH Mo OR Ni

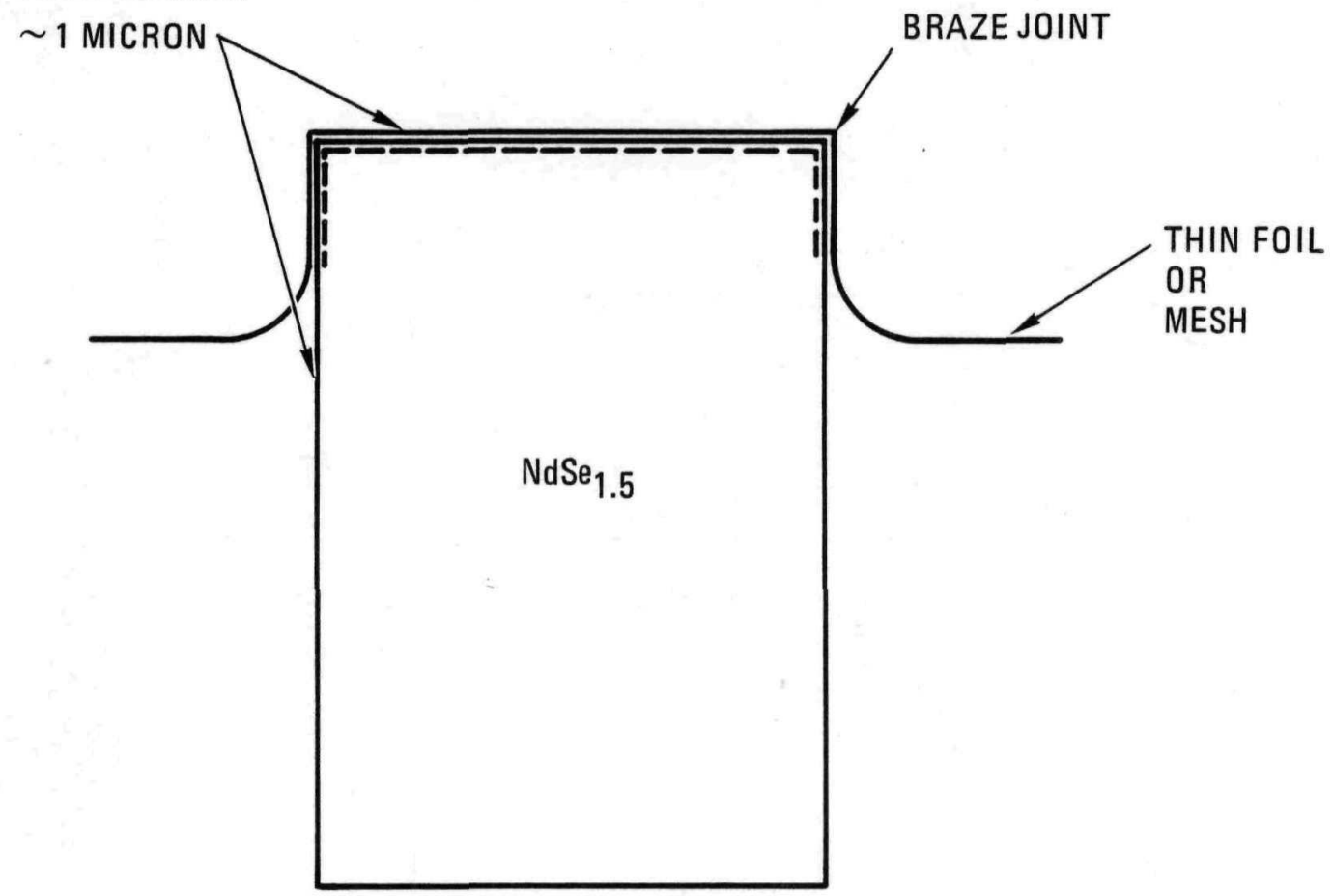

- FOIL OR MESH IS SPRING LOADED AGAINST NdSe ${ }_{1.5}$ CYLINDER

- FOIL OR MESH IS BRAZED TO THE NdSe 1.5

- Mo OR Ni ION PLATING FACILITATES CURRENT DISTRIBUTION

Fig. 3-21. Compression flexible metal-to-element joint 


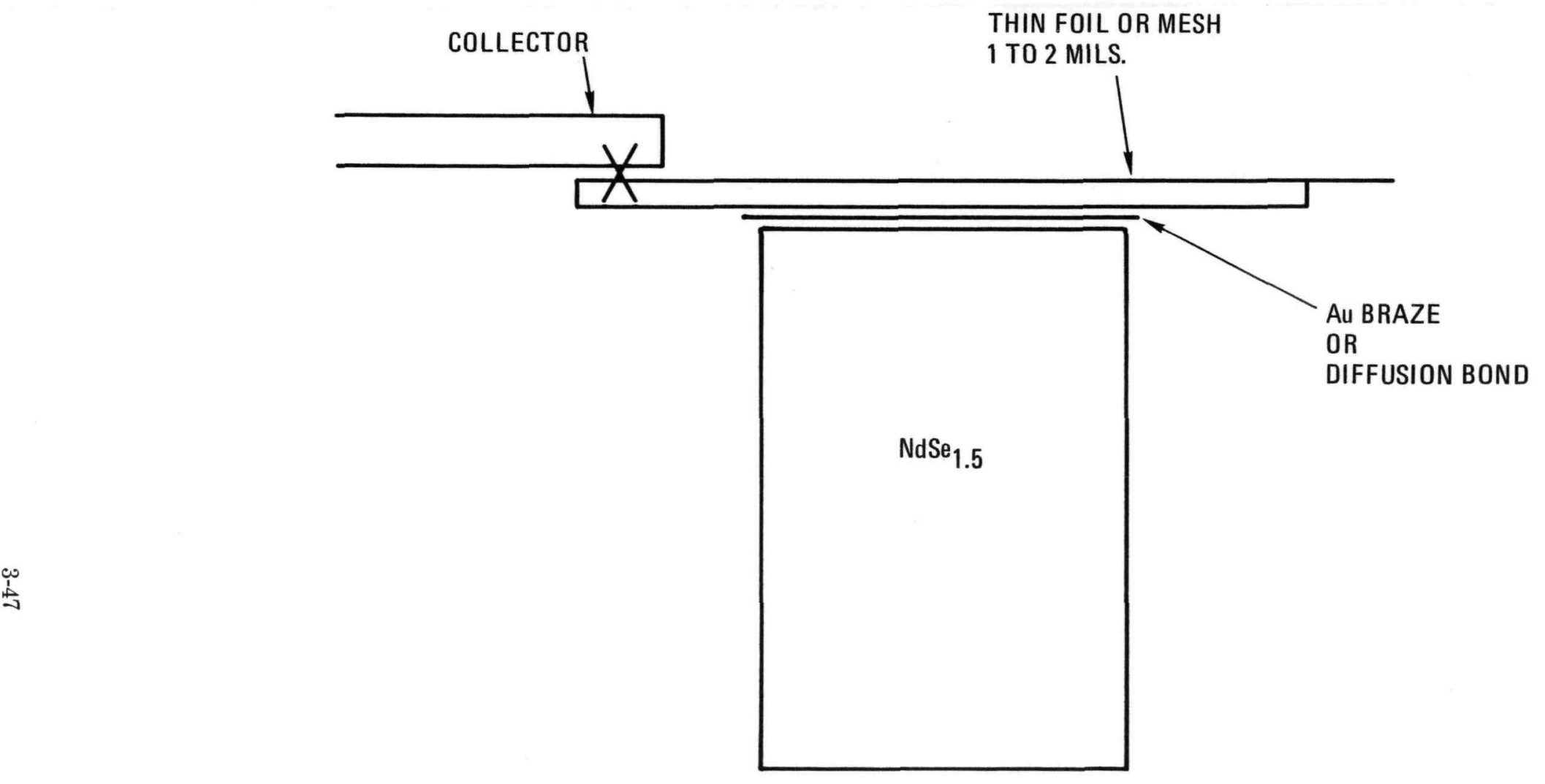

- MESH IS MORE FLEXIBLE THAN FOIL

- Au GRAZE IS VERY DUCTILE

- FOIL OR MESH CAN BE JOINED TO THE COLLECTOR BY SPOT WELDING 
$\mathrm{NdSe}_{1.5-\mathrm{x}}$ with ion plated nickel, then diffusion-bonding gold to the metallized surface. The gold was tack-welded to a nickel hot cap to complete the hot-cap-to-element joint. Gold-brazed, sweat-fitted iron caps were also evaluated. The $\mathrm{Nd}_{2} \mathrm{Se}_{3}$ cracked slightly. Program limitations prevented this concept from being examined further. The compression flexible metal-to-element joint was difficult to fabricate. Several samples were prepared, but none had a satisfactory braze joint. No further work on this concept was done.

\subsubsection{Preparation of Segmented N Elements}

The process for preparing the segmented $\mathrm{NdSe}_{1.5-\mathrm{x}} / \mathrm{PbTe}$ elements as partially developed for $\mathrm{Gd}_{2} \mathrm{Se}_{3} / \mathrm{PbTe}$ was as follows:

1. Prepare $\mathrm{NdSe}_{1.5-\mathrm{x}}$ by the diselenide process.

2. Vacuum hot press $\mathrm{NdSe}_{1.5-\mathrm{x}}$ with $1700^{\circ} \mathrm{C}, 30$-min post-annealing to control the $\mathrm{Nd} / \mathrm{Se}$ ratio.

3. Ion plate the $\mathrm{NdSe}_{1.5-\mathrm{x}}$ with $\mathrm{PbTe}$.

4. Hot press $\mathrm{PbTe}$ on the PbTe-ion-plated end of the $\mathrm{NdSe}_{1.5}$ element.

No difficulties were experienced in preparing the $\mathrm{NdSe}_{1.5-\mathrm{x}} / \mathrm{PbTe}$-bonded segments. Reproducibility of the hot cap joint still needs to be improved.

\section{REFERENCE}

3.1. Vickery, R. C., and H. M. Muir, "Anomalous Thermoelectric Properties of Gadolium Selenide," Nature 190, 336-337 (1961). 


\section{SELENIDE COUPLE DEVELOPMENT}

\subsection{TEST COUPLE 7958-109}

\subsubsection{Fabrication}

Figure 4-1 shows the components of the selenide test couple 7958-109. The $\mathrm{P}$ element consists of $(\mathrm{Cu}, \mathrm{Ag})_{2} \mathrm{Se}$ and $(\mathrm{Bi}, \mathrm{Sb})_{2} \mathrm{Te}_{3}$ segments separated by an iron barrier. MoRe is used as the P-element hot cap with a W-26/Re wire mesh in the cap joint. The $\mathrm{N}$ element was $\mathrm{NdSe}_{1.471}$, which was diffusion-bonded at the hot cap and cold caps to $0.005-\mathrm{cm}(0.002-$ in.) thick gold foil. The gold foil was, in turn, spot-welded to nickel caps at the outer rim of the gold foil. The cold caps of both elements were laser-welded to nickel radiator buttons, which were soldered to silver cold straps and a $\mathrm{BeO}$ insulator disk. The hot caps were laser-welded to nickel collectors, which were diffusion-bonded to nickel collectors. Molybdenum-opacified quartz washers were cut and wrapped around both $\mathrm{P}$ and $\mathrm{N}$ elements. Alternate layers of quartz paper and nickel foil made up the final insulation around the couple. Thermocouples were attached to the hot cap and cold caps and placed in the gap between the cold cap and the nickel radiator button. The couple was mounted in a ion-pumped vacuum system with the heater elements radiation coupled to the thermoelectric couple. This setup was quite different than previous tests in which the heaters rested on top of the P-element hot cap.

\subsubsection{Couple 7958-109 Thermal Gradient Testing}

Figures 4-2 and 4-3 show the change in Seebeck coefficient and resistivity measurements for the $\mathrm{N}$ elements of couple 7958-109 during heatup, respectively. The results show that above a $\mathrm{T}$ of $175^{\circ} \mathrm{C}$ these thermoelectric properties increase linearly with temperature.

The couple suffered two unplanned shutdowns to ambient temperature during the first 100 test hours. The couple was operated at matched load for $400 \mathrm{~h}$. The P element developed load voltage excursions after 152 test hours which became quite unstable at $190 \mathrm{~h}$, increasing in amplitude and frequency. These load voltage excursions were similar to those reported by $3 \mathrm{M}$ Company and had not been observed in previous $(\mathrm{Cu}, \mathrm{Ag})_{2} \mathrm{Se}$ thermal gradient tests.

The resistivity of the $\mathrm{P}$ element increased from an average of approximately 9.8 milliohm-cm to 11 milliohm-cm between 300 and 400 test hours. Figure 4-4 shows the resistivities and Seebeck coefficients for the $\mathrm{P}$ leg. Resistivities reported for the $(\mathrm{Cu}, \mathrm{Ag})_{2} \mathrm{Se}$ segment are estimates based on an assumed fixed value for the $(\mathrm{Bi}, \mathrm{Sb})_{2} \mathrm{Te}_{3}$ segment. After 400 test hours, the couple was operated for nearly $200 \mathrm{~h}$ open circuit. The resistivity of the $\mathrm{P}$ element increased by a factor of five just after the open circuit testing began. The electrical measurements behaved as if there were a loose electrical contact. 


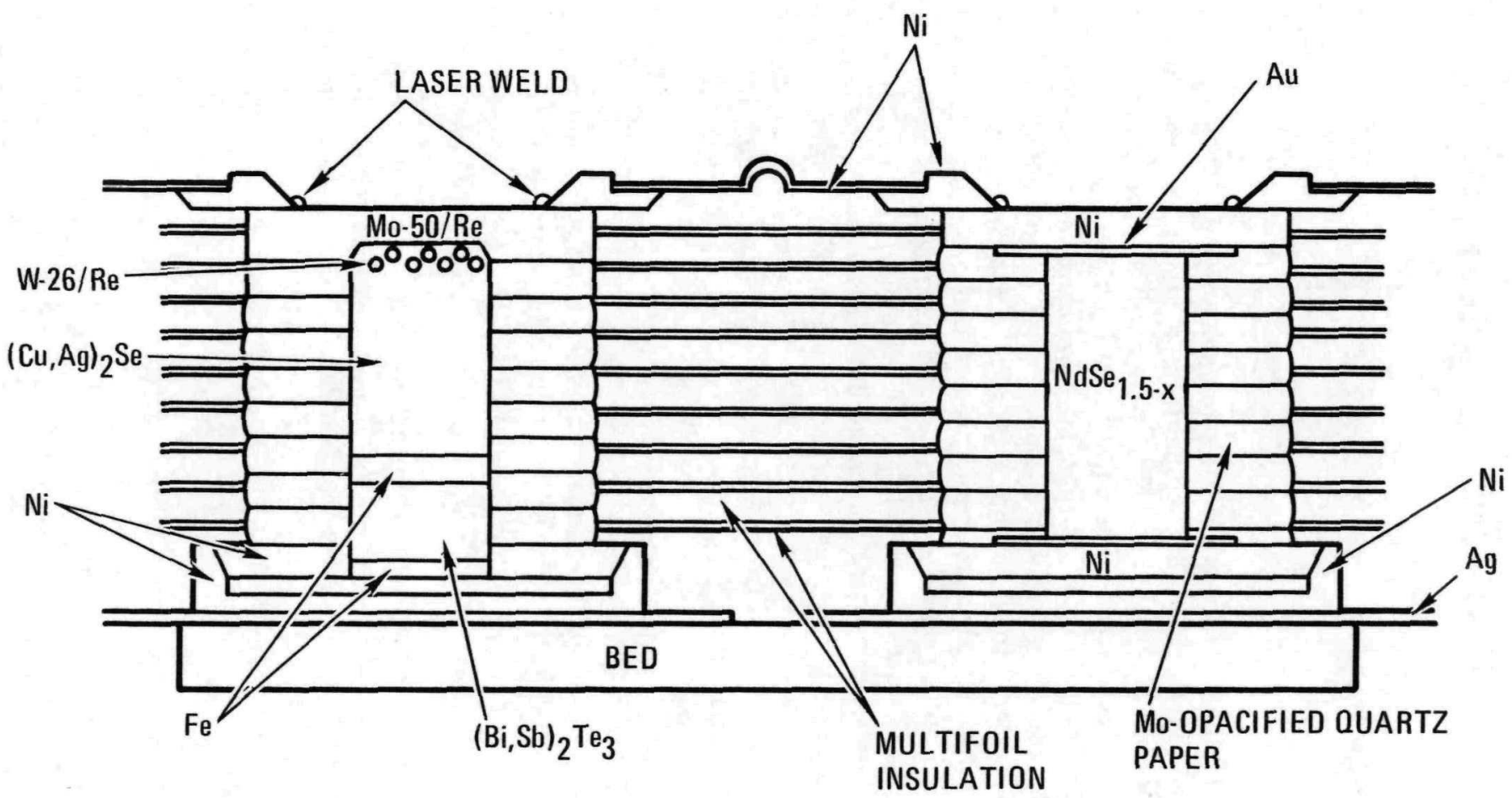

Fig. 4-1. Couple 7958-109 
$\dot{d}$

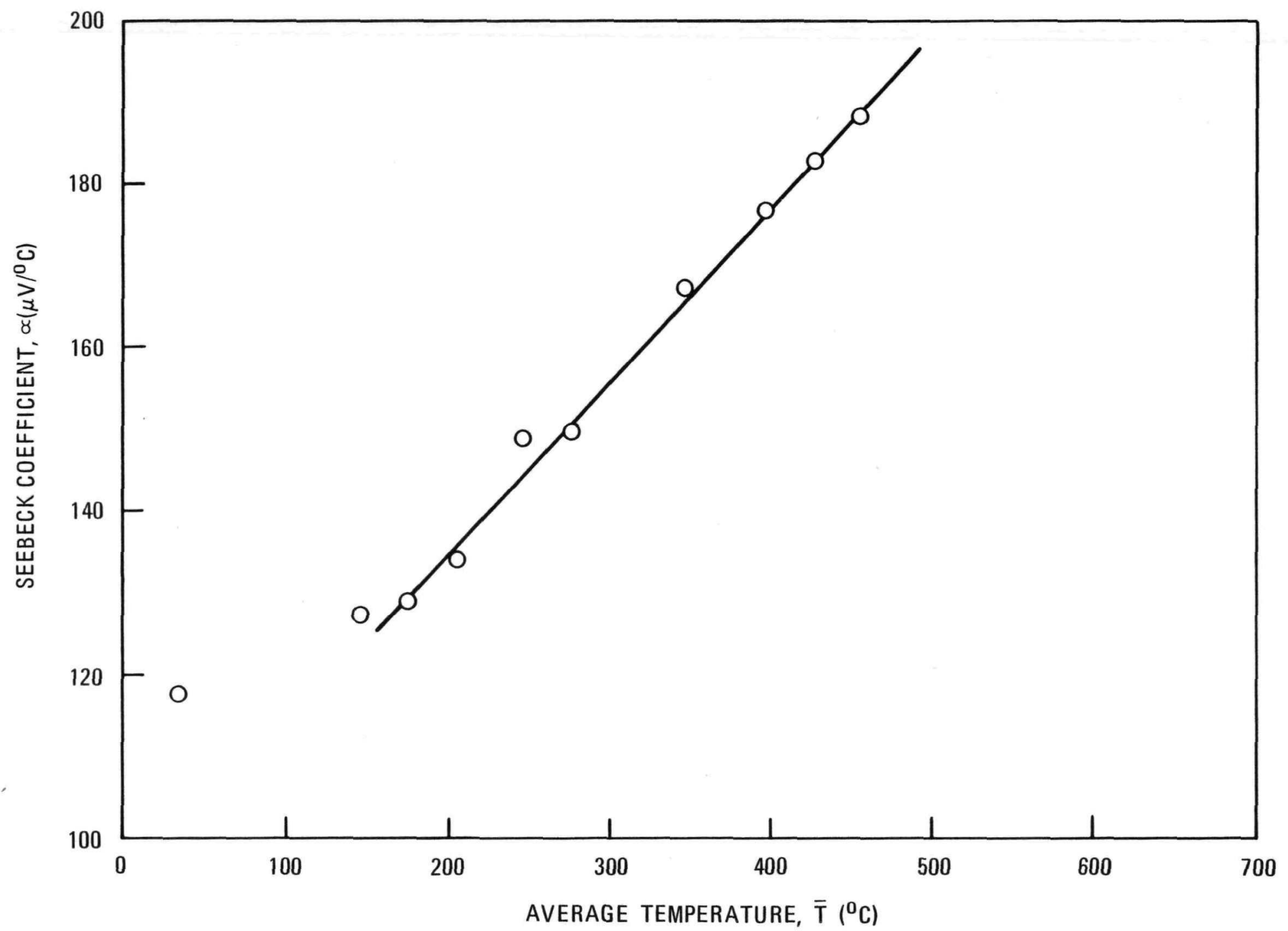

Fig. 4-2. Seebeck coefficient as a function of average temperature for $N$ leg of couple 7958-109 


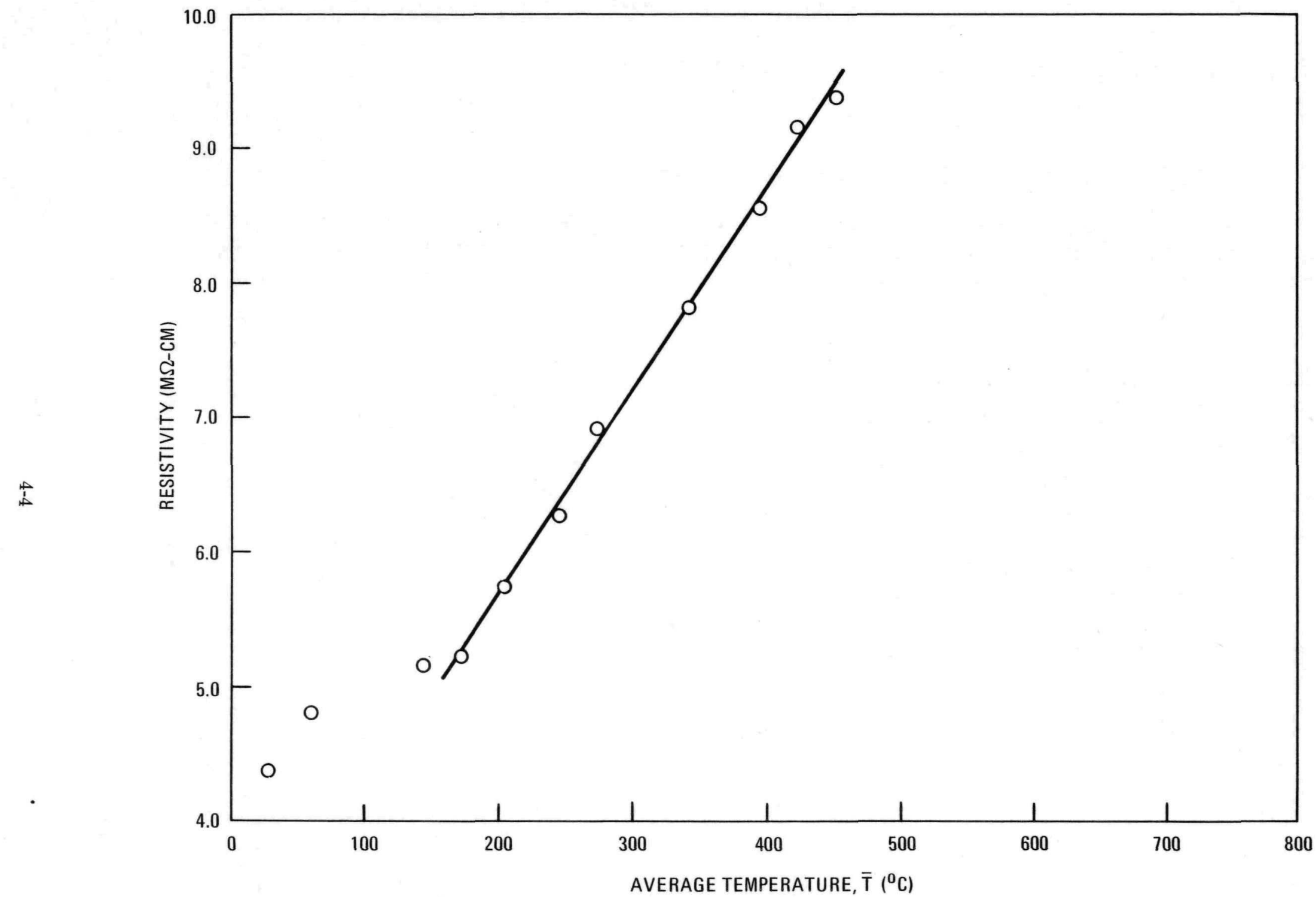

Fig. 4-3. Resistivity as a function of average temperature for $N$ leg of couple 7958-109 


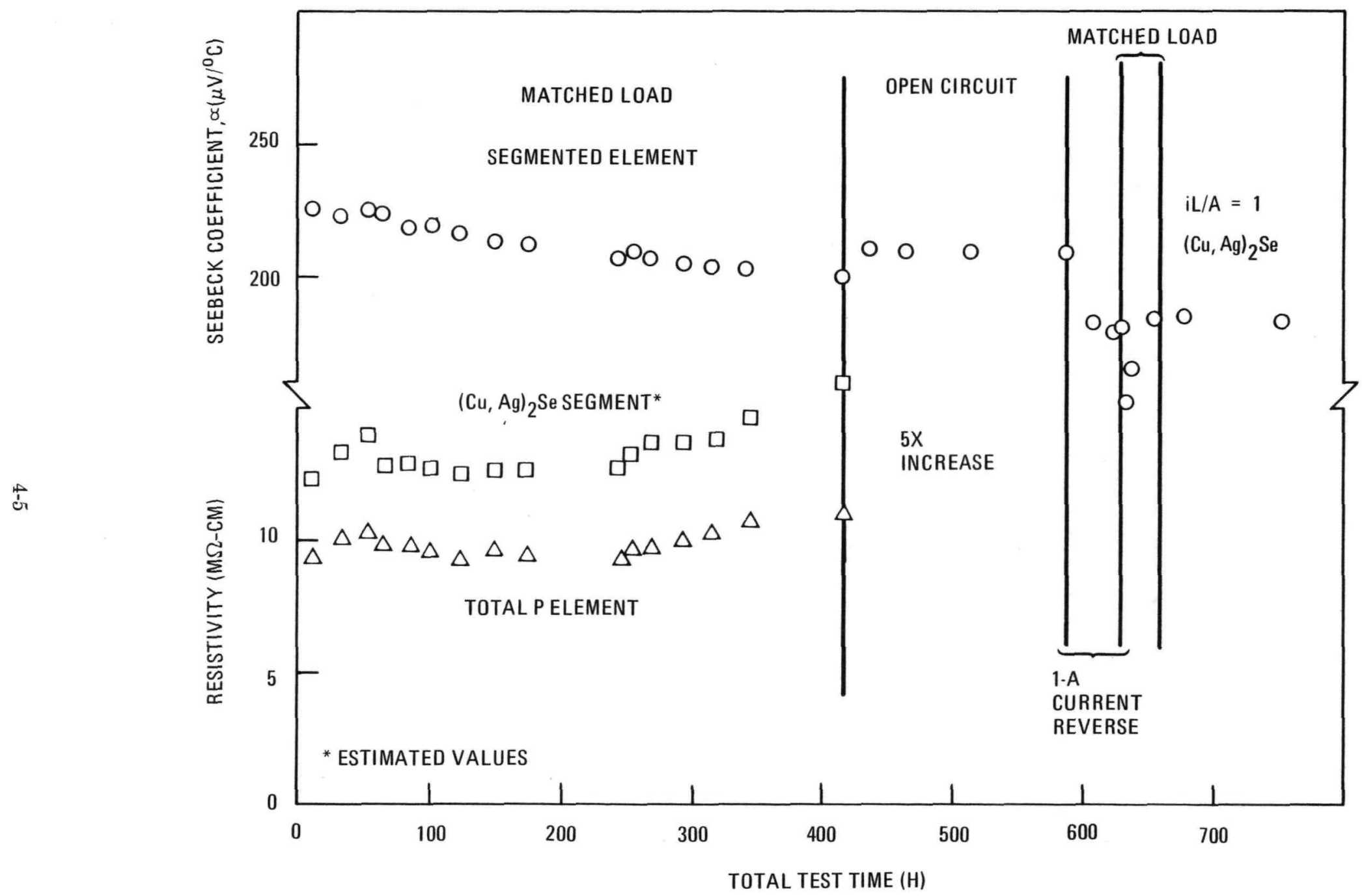

Fig. 4-4. P leg of couple test 7958-109 
The current was briefly reversed to determine if voids had developed at the hot-cap interface which would be filled by copper from the reversed current. After 2 days with reversed current, the couple was again operated with matched load. The reversed current did not lower the resistivity of the $\mathrm{P}$ element. The couple was then operated primarily to test the $\mathrm{N}$ element. A constant current supply was used to maintain an iL/A value of 1.22 through the $\mathrm{N}$ element. The load voltage of the couple was still unstable. The decision was made after 782 test hours to isolate the $\mathrm{N}$ leg, which had a very stable operation (as shown in Fig. 4-5), and continue as an element rather than a couple test. After the isolation, the current was increased to maintain an iL/A of 7 through the $\mathrm{N}$ element. The $\mathrm{N}$ element operated very stably until it was shut down after 918 test hours to make room for another couple test. Examination of this element after test showed that damage was done to the cold cap joint, apparently during gold transport from the cold cap joint into the thermoelectric element. Thus, materials which contain atoms or ions which are readily transported through $\mathrm{NdSe}_{1.5-\mathrm{x}}$ in an electropotential gradient should not be used on the cold cap end of $\mathrm{NdSe}_{1.5-\mathrm{x}}$ elements.

Microprobe examination of the $\mathrm{P}$ element from couple test 7958-109 showed traces of iron throughout the element resulting from the current reversal or contamination during element fabrication. What appeared to be a swollen portion of the $(\mathrm{Cu}, \mathrm{Ag})_{2} \mathrm{Se}$ segment turned out to be an $\mathrm{FeSe}_{\mathrm{x}}$ scale. No molybdenum, rhenium, bismuth, antimony, or tellurium were detected in the $(\mathrm{Cu}, \mathrm{Ag})_{2} \mathrm{Se}$ segment.

\subsection{TEST COUPLE 7958-125}

\subsubsection{Fabrication}

The P leg of couple 7958-125 was fabricated the same as 7958-109. The $\mathrm{N}$ leg was segmented with a $0.457-\mathrm{cm}$-long $\mathrm{NdSe}_{1.498}$ segment and a $0.203-\mathrm{cm}$-long $\mathrm{PbTe}$ segment, both $0.318 \mathrm{~cm}$ in diameter. Gold foil diffusion-bonded to the $\mathrm{NdSe}_{1.498}$ and a nickel cold cap formed the hot cap joint. Iron powder hot pressed to the PbTe segment and tackwelded to the iron cold cap formed the cold cap joint. A $0.025-\mathrm{cm}$ nickel current strap joined the two elements together.

\subsubsection{Couple 7958-125 Testing}

The segmented element of couple 7958-125 failed when heated to a $\mathrm{T}_{\mathrm{H}}$ of $455^{\circ} \mathrm{C}$. Examinations of the couple after cooldown show that tensile failure of the $\mathrm{NdSe}_{1.498}$ segment had occurred. The strain from the differential expansion between the $\mathrm{N}$ and $\mathrm{P}$ elements was apparently translated between them through the too stiff collector, as shown in Fig. 4-6. The moment of force from this strain may have also caused some partial damage of the P-element-to-hot-cap joint. The joint between the hot cap and element did not fail.

The P element from couple 7958-125 was electrically isolated from the $\mathrm{N}$ element and tested in a thermal gradient. Resistivity changes occurred in this element after $170 \mathrm{~h}$ which were analogous to the resistivity changes in the P element of couple 7958-109. Large fluctuations began to occur, and a step increase in resistivity resulted in the $\mathrm{P}$ element from approximately 7.5 milliohm-cm to $\geq 35$ milliohm-cm. Operating at a $\mathrm{T}_{\mathrm{H}}$ of $755^{\circ} \mathrm{C}$, the segmented $(\mathrm{Cu}, \mathrm{Ag})_{2} \mathrm{Se} / \mathrm{Fe} /(\mathrm{Bi}, \mathrm{Sb})_{2} \mathrm{Te}_{3}$ element has maintained a stable Seebeck coefficient measurement of $-220 \mu \mathrm{V} /{ }^{\circ} \mathrm{C}$ for 380 test hours. The cap-to- $(\mathrm{Cu}, \mathrm{Ag})_{2} \mathrm{Se}$ joint apparently failed, probably because of differential expansion between the $\mathrm{N}$ and $\mathrm{P}$ legs of the couple which were transmitted by the too stiff collector. 


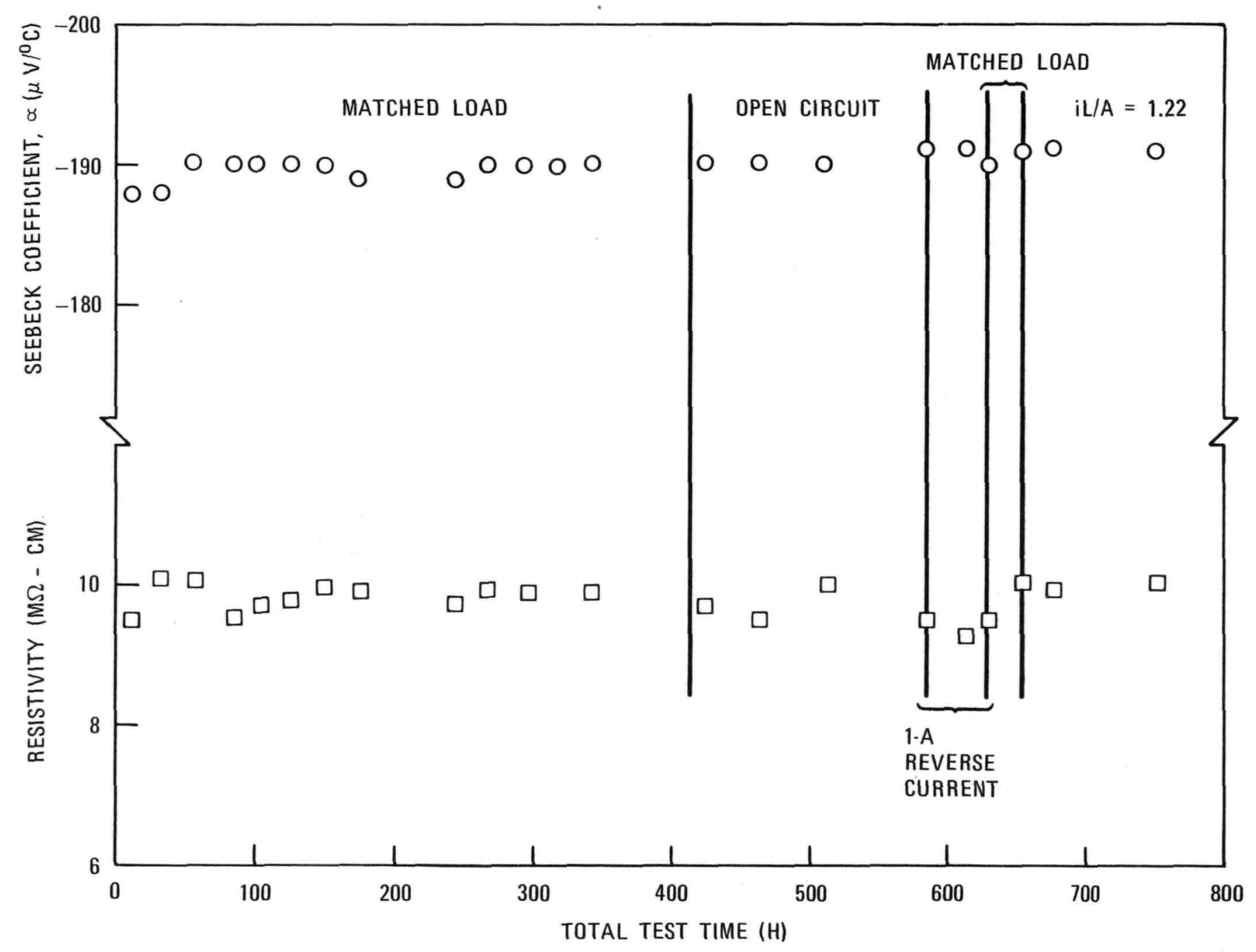

Fig. 4-5. N leg of couple test 7958-109 

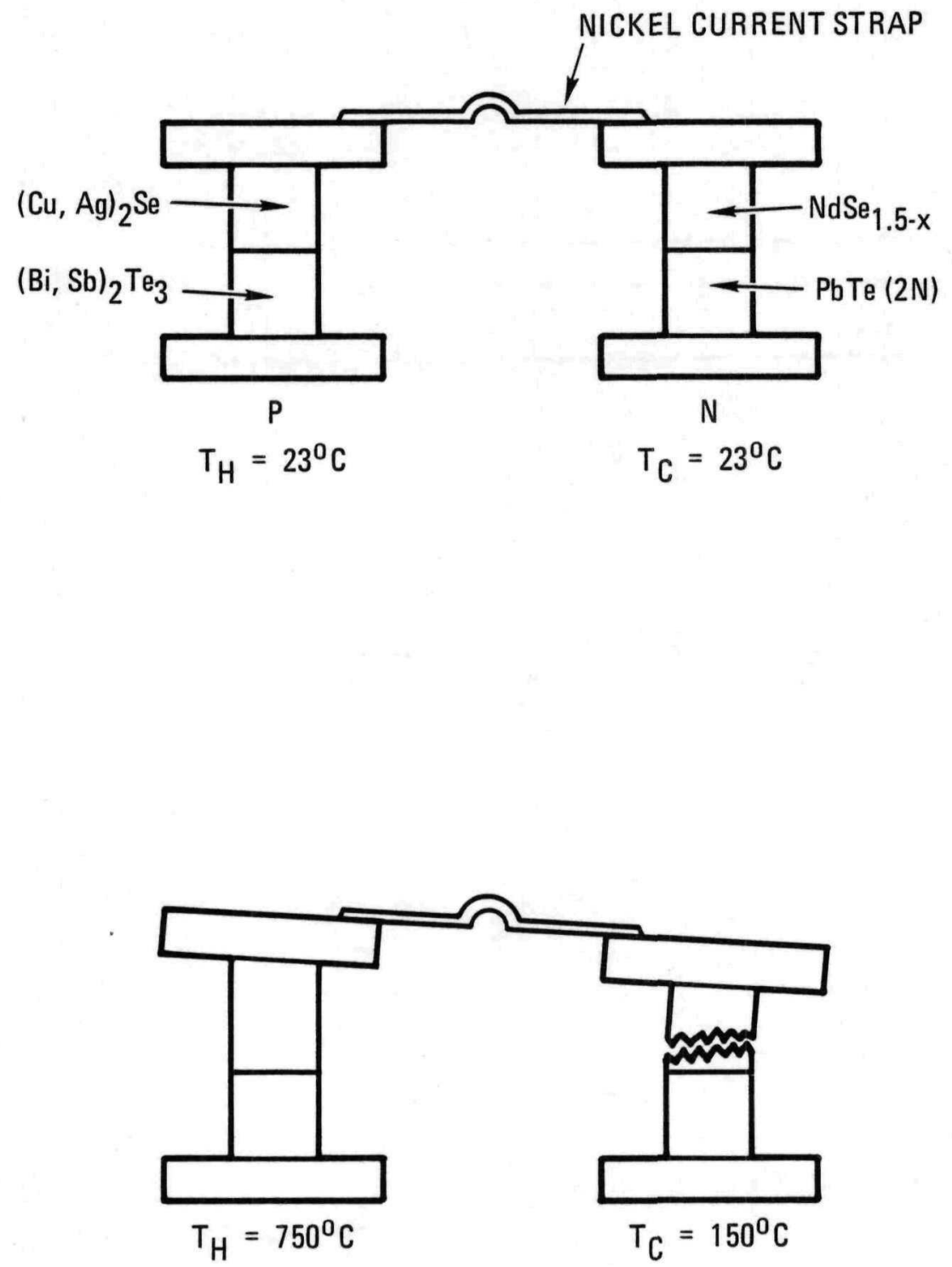

Fig. 4-6. Transfer of stress through a too stiff current strap 


\subsection{TEST COUPLE 7958-133}

A segmented couple 7958-133 was completed, as shown in Fig. 4-7. Copper used for the collector was nickel plated to provide elevated temperature stiffness. It was also coated with an organic liquid base spray coat of graphite to improve its emissivity.

The couple was put on test and heated to nominal test temperatures of $\mathrm{T}_{\mathrm{H}}=750^{\circ} \mathrm{C}$ and $\mathrm{T}_{\mathrm{C}}=160^{\circ} \mathrm{C}$. The corners of the collector gradually sagged as it was heated. Attempts to compensate for the sagging only aggravated it. As the heat source temperature increased, the region near the element hot cap became hotter and the collector corner sagged more. The greater the corner sag, the colder and stiffer the corner tips became. The corners unavoidably touched the rigid multifoil insulation. The slightly hotter collector on the $\mathrm{N}$ side of the couple was the first to touch the insulation. Slight power fluctuations caused small amplitude thermal cycles to occur. Locked to a fixed length at high temperature, the $\mathrm{N}$ element failed at the gold-to- $\mathrm{NdSe}_{1.5-\mathrm{x}}$ joint in one of the cooling portions of the mini-thermal cycle. The $\mathrm{P}$ element continued to function. The couple was then cooled to room temperature for a more detailed examination. The tensile load from the differential thermal expansion of materials was transmitted from the insulation to the P-type element through the stiffened collector. This caused the P element to fail in the $(\mathrm{Bi}, \mathrm{Sb})_{2} \mathrm{Te}_{3}$ layer. 


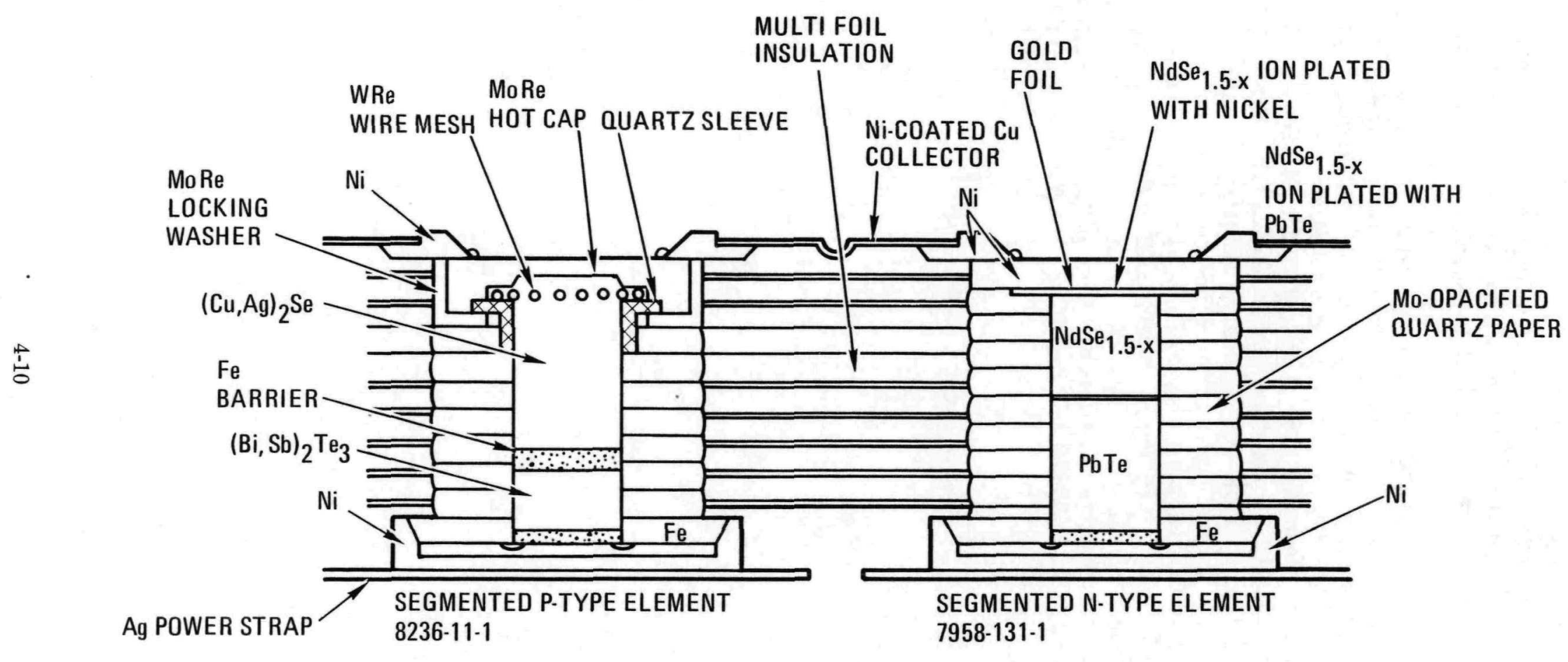

Fig. 4-7. Module test 7958-133 


\section{SUMMARY - ISOTEC TECHNOLOGY PROGRAM}

Experimental work on selenide thermoelectric materials development has now been terminated.

1. Segmented P-Type Selenide Material

a. $(\mathrm{Cu}, \mathrm{Ag})_{2} \mathrm{Se}$ was reproducibly hot pressed into P-type thermoelectric material.

b. Metallurgical contacts between $(\mathrm{Cu}, \mathrm{Ag})_{2} \mathrm{Se}$ and MoRe hot caps were developed through a WRe wire mesh joint. Graded $(\mathrm{Cu}, \mathrm{Ag})_{2} \mathrm{Se} / \mathrm{Fe}$ cold cap joints were also developed.

c. Operation of $(\mathrm{Cu}, \mathrm{Ag})_{2} \mathrm{Se}$ at hot cap temperatures above $700^{\circ} \mathrm{C}$ requires vaporizing $\mathrm{Se}_{2}$ to be suppressed.

d. Current flow through P-type $(\mathrm{Cu}, \mathrm{Ag})_{2} \mathrm{Se}$ significantly increases $\mathrm{Se}_{2}$ vaporization.

e. Vapor suppression in $(\mathrm{Cu}, \mathrm{Ag})_{2} \mathrm{Se}$ was accomplished by a multiple baffle system which consisted of an ion plated glass plus $\mathrm{Nd}_{2} \mathrm{O}_{3}$ coating, a quartz sleeve mechanical barrier, and mechanical baffling by molybdenumopacifier quartz paper washers.

f. Techniques were developed for bonding $(\mathrm{Cu}, \mathrm{Ag})_{2} \mathrm{Se}$ to $\mathrm{PbSnMnTe}-3 \mathrm{P}$ and $(\mathrm{Bi}, \mathrm{Sb})_{2} \mathrm{Te}_{3}$ to form more efficient doubly and triply segmented P-type thermoelectric elements.

g. Thermal gradient testing of a segmented P-type, $(\mathrm{Cu}, \mathrm{Ag})_{2} \mathrm{Se} / \mathrm{Fe} /$ $(\mathrm{Bi}, \mathrm{Sb})_{2} \mathrm{Te}_{3}$ element has exceeded $6300 \mathrm{~h}$ in a $755^{\circ} \mathrm{C} / 160^{\circ} \mathrm{C}$ thermal gradient at an iL/A of $7.4 \mathrm{~A} / \mathrm{cm}$ through the $(\mathrm{Cu}, \mathrm{Ag})_{2} \mathrm{Se}$ segment.

2. Segmented N-Type Selenide Material

a. Techniques were developed for preparing $\mathrm{GdSe}_{1.5-\mathrm{x}}$ and $\mathrm{NdSe}_{1.5-x}$.

b. $\mathrm{GdSe}_{1.5-\mathrm{x}}$ was found to undergo cubic to orthorhombic transformations at temperatures of $1000^{\circ}$ to $1100^{\circ} \mathrm{C}$ with slight volume and thermoelectric property changes.

c. Techniques were developed for controlling and monitoring the Se/Nd ratio in $\mathrm{NdSe}_{1.5-\mathrm{x}}$. This was found to be critical to the friability and thermoelectric properties of this material.

d. Processes were developed for hot pressing $\mathrm{GdSe}_{1.5-x}$ and $\mathrm{NdSe}_{1.5-x}$ into elements.

e. A process for making a hot cap contact to $\mathrm{NdSe}_{1.5-\mathrm{x}}$ was developed using a gold foil intermediate diffusion-bonded to the $\mathrm{NdSe}_{1.5-x}$ and welding the gold to the nickel hot cap. 
f. Techniques were developed for joining $\mathrm{NdSe}_{1.5-x}$ to $2 \mathrm{PbNTe}$ to form more efficient segmented $\mathrm{N}$-type elements.

g. Life testing of a segmented $\mathrm{N}$ element in a $750^{\circ} \mathrm{C} / 100^{\circ} \mathrm{C}$ thermal gradient showed stable thermoelectric properties despite thermal cycles and variations in current flows in a 918 -h test (This test was terminated to life test a couple).

3. All-Bonded Selenide Couple

a. An all-bonded selenide couple can be fabricated. The elements are strong enough to withstand thermal shocks and handling during thermocouple attachments, laser welding of the hot cap to the collectors, and silver soldering of the cold end radiator buttons and cold straps.

b. Elements pulled apart in short-term, thermal gradient life tests. Their failure was due to differential-thermal expansion-induced stresses transferred between elements through the current strap. Funding ended before this problem could be properly examined. From previous experience, this should not be a difficult problem to overcome. 
APPENDIX A

A PHENOMENOLOGICAL EQUATION TRANSPORT MODEL OF THE STABILITY OF P-TYPE $(\mathrm{Cu}, \mathrm{Ag})_{2} \mathrm{Se}$ AS A THERMOELECTRIC MATERIAL 